MY GENERAMION

Br

WILLIAM JEWETP TUCLER 
. 



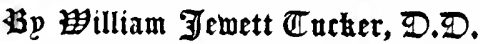

MY GENERATION: An Autoblographical Interpretation. Illustrated.

THE NEW RESERVATION OF TIME.

PERSONAL POWER. Counsels to College Men.

THE MAKING AND UNMAKING OF THE PREACHER. Lectures on the Lyman Beecher Foundation, Yale University, 1898 .

HOUGHTON MIFFLIN COMPANY

Boston AND NBW YORK 


\section{MY GENERATION}




$$
\text { . }
$$


Digitized by the Internet Archive in 2007 with funding from Microsoft Corporation 
<smiles>[Mg][Mg][Mg]</smiles> 


\title{
MY GENERATION
}

\author{
AN \\ AUTOBIOGRAPHICAL INTERPRETATION
}

BY

WILLIAM JEWETT TUCKER

President Emeritus of Dartmouth College

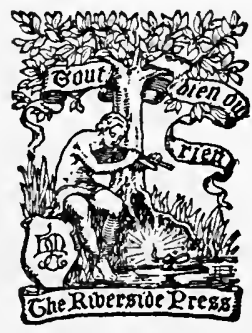

BOSTON AND NEW YORK HOUGHTON MIFFLIN COMPANY

The Riverside Press Cambridge 1919 
COPXRIGHT, I9I9, BY WILLIAM JEWETT TUCKER

ALL RIGHTS RESERVED 
To

ROBERT ARCHEY WOODS

HEAD OF THE SOUTH END (ANDOVER) HOUSE

AND

ERNEST MARTIN HOPKINS

PRESIDENT OF DARTMOUTH COLLEGE 



\section{PREFACE}

THERE must be, of course, some reason for that backward errand of the mind which is implied in autobiography. "Confessions" may be, they frequently are, the work of the imagination; but, when genuine, they have their justification in the unburdening of a mind of its past. "Reminiscences" of lighter vein are the recreation of the mind; in more serious vein, its revaluation of men and events according to the appraisal of the memory. "Interpretation" represents most nearly the unfinished work of a lifetime. In its more personal use it offers to the individual worker a just relief from his frequent sense of the incompleteness and the impermanence of his work, by allowing him to relate it to things which have in themselves fullness or stability - movements, causes, institutions. Applied in its larger relations, it may make some unfinished work of a generation, through the better understanding of it, the special task of the next, and so maintain that continuity of purpose among like-minded men which is the essential element in social progress.

It had not been my intention to write an autobiography, even in the specialized form of interpretation. The result which now appears was not a matter of design or of premeditation. Before I became interested in the preparation of this book the initiative had been taken by my wife, through her self-imposed but most gracious task of sifting and arranging the very considerable amount of memoranda and correspondence, which had accumulated during the years of my professional and semi-public service. The nat- 
ural outcome of her work, were any public use to be made of the material thus prepared, would have been a volume of correspondence edited by her, with her own annotations. Such an outcome, though presumably quite in the future, $I$ had anticipated in the event of publication. But as the sifting process went on, it became evident to both of us that the publication of correspondence, however it might be annotated, would be an insufficient and perhaps misleading treatment of the data in hand; that, in fact, the only practicable treatment must be in the way of autobiographical interpretation. In the first place, the correspondence was incomplete, as few copies of my own letters had been preserved, and many of the letters received, naturally the most interesting, were in their prevailing character confidential. Furthermore, my professional career had been divided not only in time and place, but still more according to the specific objects which had been pursued, requiring a personal knowledge of motives and purposes to give it the requisite unity. And further still, the spirit of my whole work had been so far related, at least to myself, to what $I$ have termed the fortune of my generation, that it could hardly have been interpreted except by the one who had passed through experiences incident to the peculiar incentives and influences of the generation. For these reasons the book assumed its present more personal form, but the making of it was none the less a work of collaboration.

Enough only of the personal has been introduced into this "Interpretation" to serve as a background for the professional point of view. I am well aware that any interpretation of one's generation to be of value must be genuinely and broadly human. But the next demand, as I 
apprehend, is for definiteness of view, a certain recognizable if not authorized relation of the would-be interpreter to his time. Such a relation may be properly assumed to exist between a man and his profession. As compared with the outlook of a mere observer, the professional view is from within the generation. It is more than a view; it is an experience, an experience of the inner life of the generation and of its responsible activities. Among the professions of my time, I know of none which made more vital contacts with the working forces of the generation, or shared more sensitively in the quickening or disturbing influences of its intellectual life than the ministry. There were at least three specific objects of very great interest and concern to the ministry, in so far as it was affected by the progressive spirit of the new era - the advancement of theology, the development of the social conscience into an agency adequate for social progress, and the expansion of the higher education to admit the subject-matter and discipline of the new knowledge. This last object, especially as it came within the range of the ministry through the New England traditions, involved the reconstruction of the institutional life of the colleges quite as much as the readjustment of the curriculum.

During the period of my two pastorates (1867-80) it can hardly be said that these objects had taken definite shape. I was more conscious of a general enlargement of the scope of the ministry - at Manchester, of the widening outlook toward industrialism; in New York, of a growing sensitive; ness to the human needs of the city. There was, however, the increasing consciousness that the prevailing unrest was seeking definition as the first step toward satisfaction. And it was with the purpose of entering into a clearer 
understanding of the new responsibilities of the ministry, and of taking some more directive part in the training of men for its new duties that I made the change from the work of the pastorate to that of the schools.

The two periods which follow that of the pastorate, which I have designated the Andover period (1880-93) and the Dartmouth period (1893-1909) were outwardly unlike - one was theological, the other was educational; one was controversial, the other altogether constructive. But the same influences from without and the same spirit within were at work in each. In the circumstances of the time, theological advancement, including the new sociological development, and educational reconstruction were not far apart in aim or method. I have not, however, used these general terms to designate the two periods, because I have wished to emphasize in each case the institutional element. The so-called Andover Controversy was singularly out of place - it belonged anywhere rather than at Andover - but because of its variance with all the traditions of the Seminary it doubtless "fell out" to the furtherance of theological freedom and progress in a way impossible in an unprogressive school. The part which Dartmouth took in educational reconstruction was similar to that taken by other colleges of its grade, but there was that about the process as carried out which gave it an institutional result quite distinctive and unique. As a college administrator, my work included a specific task undertaken for an institution which had summoned its loyal alumni to meet in its behalf a belated and restive opportunity.

The closing period to which I have referred under the title, "The New Reservation of Time," represents, in the 
changed conditions of modern life, a new but most valuable perquisite of age. It has been to me, in its extent at least, an unexpected gift, reaching now to a decade, and enhanced in value beyond all estimate by the events which have crowded the later years. To have lived in such a period, to have shared in its grave anxieties and mighty hopes, to have been able to study into the causes which were producing such momentous sacrifices and struggles, and to have been allowed to witness the final consummation, all this has made the period of retirement more significant, even within the sphere of personal expression, than any preceding period of responsible activity. It has not been, I trust, inconsistent either with previous activities, or with the natural restraints consequent upon official retirement, that I have ventured from time to time, under the stimulus of passing events, into the open field of the publicist.

I am indebted for the title of this book, as well as for many other helpful suggestions, to Mr. Homer E. Keyes, Business Director of Dartmouth. His advice and aid in regard to illustrations have been of peculiar value. The map of Dartmouth College was especially prepared by $\mathrm{Mr}$. Harry G. Wells, Superintendent of Buildings and Grounds.

Professor Frank H. Dixon very kindly assumed the reading of the proof. This meant much more than the correction of errors in print (these are slight in the galleys of The Riverside Press). It meant in the present instance the verification of quotations and dates, and not infrequently the revision of paragraphs, in order to avoid those repetitions and inconsistencies which were liable in a book dictated at intervals as strength permitted. 
xii

I desire to express my appreciation of the continued hospitality of Houghton Mifflin Company, a hospitality which, in one form or another, I have enjoyed for more than thirty years.

July, 1919

William Jewett Tucker 


\section{CONTENTS}

I. The Fortune of my Generation . . . . . 1

An Introductory Retrospect . . . . . . . 1

II. The Personal Background. . . . . . . 19

Ancestry and Early Home . . . . . . . 20

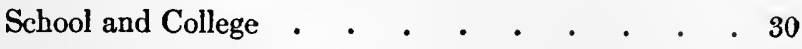

III. The Environment of the Civil War . . . . 41

IV. The Profession of the Ministry . . . . . 51

V. Two Pastorates . . . . . . . . . . . 63

The Franklin Street (Congregational) Church, Manchester, New Hampshire, 1867-1875 . . . . 64

The Madison Square (Presbyterian) Church, New York

City, 1875-1880 .. . . • . . . . . . 71

VI. The Progressive Movement in Theology $\quad . \quad 90$

VII. The Andover Period: Andover as a Storm Center And as a Working Center, 1880-1893 . . . 100

I. The Opening Phase of the Andover Controversy 101

II. The Andover Movement and the Religious Public 125

III. Andover as a Working Center during the Decade of Conflict . . . . . . . . . 159

IV. The Andover Trial and its Result . . . 185

VIII. Andover and Dartmouth, 1892 . . . . . . 292

IX. The Dartmouth Period: Modernizing an HisTORIC COLlege, 1893-1909 $\quad$ • . . . . . . . 248

I. "The Corporate Consciousness of the College" . 249 
II. The Traditions of Dartmouth . . . . 271

III. Reconstruction and Expansion . . . . 296

IV. The New Morale . . . . . . . . 323

V. An Advanced Policy toward Non-Professional

Graduates . . . . . . . . 349

VI. Professional and Public Relations during the

Presidency . . . . . . . . 362

VII. Two Years of Crippled Leadership . $\quad . \quad$. 394

X. “The New Reservation of Time" . . . . . 414

A Partial Resumption of Literary and Semi-Public Work 414

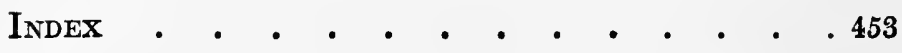




\section{ILLUSTRATIONS}

William Jewett Tucker • • . Photogravure frontispiece

The Tucker Homestead at Griswold, Connecticut . 20

Dartmouth College, 1857-61 . . . . . . . . . 36

Professors in Andover Seminary in the Early Sixties 56 Calvin E. Stowe, Austin Phelps, Edwards A. Park

Madison Square Church in the Seventies $\quad . \quad$. 74

The Defendants in the Andover Trial . . . . 188

George Harris, William J. Tucker, Egbert C. Smyth, Edward Y. Hincks, John W. Churchill

The Tucker Home at Andover . . . . . . 230

The Seminary Grounds opposite the House . . . . 230

Tonib of Eleazar Wheelock, Hanover · . . . . 272

The Laying of the Corner Stone of the New Dartмouth Hall . . . . . . . . . . . . . 276

Map of Dartmouth College Grounds . . . . . . 310

College Hall (College Club and Commons) . . . 314 EdWARD TUCK . . . . . . . . . . . . . 318 Webster Hall . . . . . . . . . . . . . . 322

Rolins Chapel INterior after the First EnLargement 344

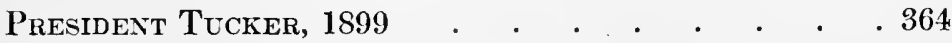

The Hone on Occon Ridge overlooking the River . 416 The Connecticut River at Hanover . . . . . . 439

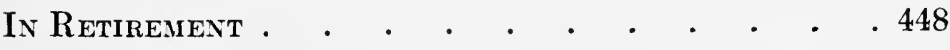





\title{
MY GENERATION
}

\author{
CHAPTER I \\ THE FORTUNE OF MY GENERATION
}

An Introductory Retrospect

The generation which was beginning to take shape and character when I came of age, was to have the peculiar fortune, whether to its disadvantage or to its distinction, of finding its own way into what we now call the "modern world." If I were to characterize the generation as I look back upon its course, I should say that it was by this necessity a self-educated generation. The great gift of educational value which came to it from the past, through the faithful transmission of the previous generation, was discipline, the intellectual and moral discipline of the old régime. The actual process of self-education began with its conscious entrance into the world of the new knowledge and of the new values, constantly opening before it. This process was progressive rather than cumulative. Men no longer estimated one another by the relative amount of their knowledge, but rather by their relative power of intellectual initiative, by their ability to enter the new fields of inquiry and research, and to occupy advanced positions.

I have referred to this peculiar condition or circumstance in which the lot of my generation was cast, as its fortune. It came, that is, in the order of time, and not, with a single exception, by the compulsion of some great inheritance, or by the setting apart to some specific duty. The stimulus, the incentive, the challenge was altogether 
in the situation itself. Men found themselves singularly stirred to think new thoughts and to attempt new methods of action. There was no manifest unity of purpose in the spirit of the age, but all movements, though often conflicting, were seen to make for progress. Gradually the desire and struggle for progress became the unifying purpose of the generation. The self-education of which $I$ have spoken developed more and more in all departments of life into a passion for progress.

The peculiar fortune of the generation becomes evident and clear as we give due account to its place in the order of time. It explains what was by far the most significant fact in its fortune, namely, its intellectual detachment in so large degree from the past. It is not difficult to place the cause, or to fix the date of the break between the old order of thought and the new, provided we make due allowance for the intervening period between the time when the break took place, and the time when it took effect. By common consent, the break came with the publication of the "Origin of Species." This was in the fall of 1859. The significance, however, of the publication of the "Notes," as Mr. Darwin modestly called the treatise, was not readily apprehended, doubtless in part because of the unassuming way in which it was put forth. The most that Mr. Darwin then claimed is summed up in the following words, of which the last sentence only is now really prophetic: "When the views entertained in this volume on the origin of species, or when analogous views are generally admitted, we can dimly foresee that there will be a considerable revolution in natural history. . . . In the distant future I see open fields for far more important researches. Psychology will be based on a new foundation, that of the necessary acquire- 
ment of each natural power and capacity by gradation. Light will be thrown on the origin of man and his history." It was not till 1871 that Darwin published "The Descent of Man," embodying his conclusions regarding the derivation of man's nature from lower and still lower forms of animal life.

An interesting reminiscence, showing the rather casual manner in which the earlier volume came to the notice of persons of culture in this country, has been given by the late Rev. Dr. Charles C. Caverno, of Lombard, Illinois. Dr. Caverno was at the time of the incident a young lawyer in Milwaukee, and was acting as chairman of a committee on the Public Library of the city. "Sometime in the winter of 1859-60," he says, "Ralph Waldo Emerson, who was then giving a course of lectures in Milwaukee, asked me if I could procure him a copy of a book on Species, which an Englishman had published lately, and he added, 'from what I have heard it is likely to make the dry bones rattle.' I have given," Dr. Caverno adds, “Mr. Emerson's description of the book he was after, for he gave no name of author or definite title of book."

However casual may have been the introduction of "The Origin of Species" among general readers of non-scientific habits, it was not long before it began to change the intellectual atmosphere. It gradually changed the point of view. Men began to see things differently. The intellectual detachment from the past was brought about chiefly through this change in the point of view, - a change set forth with great clearness by Mr. Balfour in his analytic retrospect of the nineteenth century. "No century," he says, "has seen so great a change in our intellectual apprehension of the world in which we live. It is not merely that this cen- 
tury has witnessed a prodigious and unexampled growth in our stock of knowledge, - for new knowledge might accumulate without end, and yet do nothing more than fill in, without materially changing the outline already traced by the old. Something much more important than this has happened. Our whole point of view has altered. The mental framework in which we arrange the separate facts in the world of men and of things is quite a new framework. The spectacle of the universe presents itself now in a wholly changed perspective. We do not see more, but we see differently."

Doubtless the intellectual detachment from the past was effected with less violence through changing the point of view, than would have been possible through any other method. And yet the result was not gained without opposition, and in some quarters sharp antagonisms. The scientific renaissance, if such we choose to term it, was not like the revival of letters in the fourteenth and fifteenth centuries, making itself felt through the diffusion of light and culture, and creating a more spiritual environment. In reality, it was not so much a renaissance as a revolution. It became articulate as a challenge, calling in question the established order of thought, and summoning men to new ways of thinking. The controversial aspect of the scientific renaissance or revolution became manifest more quickly and more seriously in Great Britain than in this country. This was due, I think, in no small measure to the presence of such pugnacious advocates of the new theories as Huxley and Tyndall, who found a welcome opportunity for controversy in the conservatism and conventionalism of the English Church. So sensitive were the religious interests which the controversy touched, that men quite remote 


\section{THE FORTUNE OF MY GENERATION 5}

from ecclesiastical or theological connections were drawn into it. As early as 1864 Disraeli, in a speech before a dioscesan conference at Oxford, uttered his famous mot "The question before us is this, Is man an ape or an angel? I, my lord, I am on the side of the angels." Within the next decade, Oxford was aflame with the controversial spirit which had spread in all directions. "Darwinism," says Mrs. Humphry Ward in her recent "Recollections," "was penetrating everywhere; Pusey was preaching against its effects on belief; Balliol stood for an unfettered history and criticism, Christ Church for authority and creeds; Renan's 'Origines' were still coming out, Strauss's last book also; my uncle [Matthew Arnold] was publishing 'God and the Bible' in succession to 'Literature and Dogma'; and 'Supernatural Religion' was making no small stir."

That the controversy was carried on with less bitterness in this country was due in part, of course, to the preoccupation of mind with the affairs of the nation (1860-70), but still in part to the different religious or ecclesiastical conditions which obtained here. The difference in tone may also be attributed to the marked contrast in the temper of our leading scientists of the period-Agassiz, Gray, and Dana. There was a good deal of attempted sarcasm of the Disraeli order, which found expression in the pulpit, but the higher religious journals and reviews spoke with becoming restraint. Especially noticeable in this regard was a series of articles in the "Bibliotheca Sacra," the leading theological review of the time, by Professor George Frederick Wright of Oberlin, then the young pastor of the Free Church in Andover, Massachusetts. These papers were characterized by a breadth and candor, and above all by 
a thorough comprehension of the real questions at issue, which make them still an example of fair-minded and intelligent discussion in place of controversy.

The secondary stages of the scientific controversy in this country were more marked than the earlier stages in their effect upon religion. The various phases of Biblical Criticism, which followed as a natural sequence from the application of the new scientific standards to the Bible, awakened more concern, and stirred more bitterness, than the new hypothesis regarding the origin of man. And the after effect of the controversy upon the popular as well as upon the critical mind was for the time disturbing to religious faith. The wave of agnosticism which spread over the country necessitated various changes in the presentation of religious truth. A larger place was given in the teaching of the seminaries to the department of Apologetics; more emphasis was placed by the pulpit upon conduct and duty; and gradually there was an appropriation of the new truths disclosed by science in the interest of ethics and of faith. As a general result, I think that it may now be said that the loss to religion of certain dogmatic but divisive beliefs found in due time its compensation, in the insistence placed upon the function of conscience in the interpretation, as well as in the enforcement of religion.

I have referred at some length to the religious controversy attending the scientific revolution, because it produced at first a greater effect as a disturbing force in religion than as a constructive force in education. Of this latter effect I shall have much to say in detail hereafter. The educational effect when it came was twofold: it brought in a vast amount of new subject-matter, and it changed altogether the method of the higher education. Of these two 
effects, the latter was by far the more revolutionary. In fact, the scientific method may be said to have created some subjects in the curriculum of the colleges, to have recreated others, and to have changed the relative position of certain other subjects, as in the case of the ancient and modern languages. Within the range of college and university teaching, the greatest contribution of the scientific method was the graduate school. Various attempts of a partial nature had been made to anticipate this object, but the opening of Johns Hopkins in 1876 inaugurated the epoch of graduate instruction. Beyond this contribution was the establishment of the research foundation, separating investigation from teaching, in which Johns Hopkins led the way in the advanced study of medicine.

I have emphasized the fact that, with a single exception, the fortune of my generation was not predetermined by its inheritance. That exception however, though local, was of the highest consequence. Before it passed off the stage, the preceding generation in this country had reached the climax of its moral power in the struggle for the abolition of slavery. A part of its unfinished task went over to my generation. The whole spirit of the struggle went over as a moral heritage, - the bequest of the Puritan conscience at the stage of its greatest activity. The bequest took precedence of the new gifts which marked the intellectual abundance of the modern age. It was not something to be accepted or denied: it was to be taken at its full value and put to immediate use. Due consideration must be given to this relation of the generation to its moral heritage, as the explanation in part of the slow awakening of intellectual life in this country to the scientific renaissance. To go back no farther than the opening decade of the last half of the 
century, we find that the generation then in responsible relation to the country was charged with the moral passion of the struggle leading up to and culminating in the Civil War. Compared with the very complex issues which marked the close of the century, social, economic, and political, the issues of that time were simple, almost elemental. There were but two vital questions before the people, the preservation of the Union, and the elimination of slavery, and gradually these became one and the same question. The Seventh of March Speech by Mr. Webster (1850) was the last serious but pathetic effort, - pathetic both in its sincerity and in its futility, - to save the Union without first destroying slavery. Thenceforth, throughout the decade, the struggle was essentially "the anti-slavery struggle." The consequences to the nation itself were not sufficiently imminent to restrain or confuse the moral sentiment which was aroused. It was not until the war was well under way that the preservation of the Union was seen to be the paramount, because the inclusive issue, (as was predicted by Mr. Webster), carrying with it as a national necessity the destruction of slavery. The spirit of nationality, which had dominated the mind of Mr. Webster in his view of the impending conflict, then reasserted itself in the mind of Mr. Lincoln. In his reply, August 22, 1862, to the open letter of Horace Greeley in the "New York Tribune," severely criticizing the policy of the Administration, Mr. Lincoln made this clear and decisive statement of his policy: "My paramount object in this struggle is to save the Union, and is not either to save or to destroy slavery. . . What I do about slavery and the colored race, I do because I believe it helps to save the Union; and what I forbear, I forbear because I do not believe it would help. 
to save the Union." And yet so inextricably was the destruction of slavery bound up in the saving of the Union that a month after the date of the above statement, $\mathrm{Mr}$. Lincoln issued the preliminary proclamation of emancipation, an act to which he afterwards referred as "the central act of my administration."

It was because of the fact that the Civil War, as it advanced, became more and more on the part of the North a struggle for the national existence, that the anti-slavery feeling was stronger, certainly more demonstrative in the decade preceding the war than during the war. Throughout that decade slavery, in and of itself, was the paramount issue. It vexed, with increasing intensity, the conscience of the North. Occasions calculated to arouse and inflame public sentiment followed one another in rapid succession, - the arrest of the fugitive slave, Anthony Burns, in the streets of Boston, and like incidents connected with the enforcement of the Fugitive Slave Law, the fraudulent and violent attempts to impose slavery upon Kansas, the assault upon Charles Sumner at his desk in the Senate Chamber, the Dred Scott Decision, the John Brown Raid, the secession of South Carolina. The anti-slavery literature of the time, often the product of genius, compelled public attention. This literature was remarkable for its variety, "Uncle Tom's Cabin," the editorials of Garrison and Greeley, the sermons and addresses of Beecher, the platform speeches of Phillips, the prophetic utterances of Whittier and Lowell, the debates of Seward and Sumner in the Senate, and the campaign speeches of Lincoln in reply to Douglas.

Perhaps the most effective agency for the propagation of the anti-slavery reform was the lecture platform, then 
known as the Lyceum, as it gave the reformer direct access to the people. Nearly all the popular lecturers of the time were pronounced anti-slavery men. When they discussed other subjects than slavery, they made their personal influence felt for the "cause." The reply of Wendell Phillips to a lecture committee, when asked for his terms, embodied the spirit of the whole anti-slavery brotherhood, - "Let me take my subject and I'll come for nothing: for any other subject seventy-five dollars." Out of this training there came not only moral but intellectual results of a high order. The anti-slavery agitation produced its own school of thought and style. In many instances, the school gave the equivalent of a liberal education. Garrison, Greeley, and Whittier were not college graduates, but they were the intellectual peers of Phillips, Lowell, and Seward. Mr. Lincoln was the conspicuous product of the school. Without the slightest advantage from any of the conventional forms of intellectual training, except his early practice in the local courts, he became, and remains, among the men of his time the acknowledged master of argument and style. Recalling the fact that the subject-matter of Mr. Lincoln's thought was chiefly concerned with slavery, it is interesting to note the relative proportion of his public utterances, compared with those of other men, which has been incorporated into literature, - the speech in Cooper Institute, remarkable for its simplicity, its logical power, and its moral grandeur; the second Inaugural, without a like or equal among state papers in the records of any nation, and the Gettysburg Speech, unmatched for its chastened eloquence.

A singular intellectual and moral phenomenon is the reappearance of Mr. Lincoln in connection with the issues 
and events of the present war, through frequent reference to his acts, and through constant quotations from his messages and speeches. It is hardly possible to read any of the English papers for a month - notably the London "Spectator" - without meeting with some serious allusion to Mr. Lincoln. He appears to be more in evidence than any British statesman. Very much of this return to him is due to the similarity between the fundamental issues at stake in the present war, and those of the Civil War, but much more to Mr. Lincoln himself, and to his incomparable power of stating moral principles with a finality which holds good for all time.

It was impossible that such a moral campaign as that of the anti-slavery speakers and writers could be waged for any length of time without producing definite and farreaching results. Early in the decade (1850-60), the public sentiment thus created began to crystallize in local political organizations in several of the Northern States. In 1856, the national Republican party was formed, pledged to resist the further encroachment of the slave power. After a single defeat in a national contest, the party effected the election of Mr. Lincoln to the Presidency. When the war actually came, it was to many a war of atonement for the wrongs of slavery, a war of national repentance. And such it was to the end in the deep undercurrent of the national feeling, as interpreted by Mr. Lincoln in the memorable passage from his second Inaugural, March 4, 1865 : "Fondly do we hope - fervently do we pray - that this mighty scourge of war may speedily pass away. Yet, if God wills that it continue until all the wealth piled by the bondsman's two hundred and fifty years of unrequited toil shall be sunk, and until every drop of blood drawn with the 
lash shall be paid by another drawn with the sword, as was said three thousand years ago, so still it must be said, 'The judgments of the Lord are true and righteous altogether."'

The revival of Puritanism, which was so evident throughout the anti-slavery conflict, and to a large degree throughout the war, was naturally followed by a certain relaxation of the national conscience when the war was over. The moral tension could not be maintained after the crisis was passed. There was also a distinct lowering of the intellectual tone of national politics. The period which followed the Civil War had little of the moral grandeur of the period which preceded it, and much less intellectual power. Had Mr. Lincoln lived, the result might have been different,possibly not. Other men fell below their standards. The debates in Congress, which had been characterized by seriousness and dignity, even when most heated, were marked more and more by party animosities, and by personal bitterness. The Government remained substantially in the hands of the men who had carried the nation through the war, but their statesmanship was not so evidently equal to the new task. Divergent policies on the part of the leaders resulted in much confusion, and led to many unwise and arbitrary acts. Corruption also, which had not been altogether absent during the war, came in more openly in the process of reorganizing the States that had been in rebellion. On the whole, the political atmosphere which hung over the nation during the period of reconstruction was heavy and depressing. There were those who saw or affected to see in the death of Mr. Lincoln, coincident with the close of the war, a possible advantage to the country in the transfer of the executive authority to sterner hands, 
but the immediate effect was a moral relapse. And time has shown that what the work of reconstruction most lacked was the moral genius of Mr. Lincoln.

It may not, however, be assumed that because the nation suffered a certain moral relapse after the war, the impulse of the moral heritage became a spent force. The impulse persisted, especially in its continuous influence upon individual life. Men went about their work under a new sense of responsibility. Side by side with the work of national reconstruction, there was the vast work of reconstructing the economic, social, and religious life of the country, which was in one way or another every man's business. And for this task the earlier education, with its more rigid moral discipline, was still efficacious, in spite of its lessening intellectual authority. It remained, as I have intimated, a steadying force in the midst of the quickening but distracting influences which marked the incoming of the "modern era." In referring to the abolition of slavery as the unfinished task of Puritanism, I do not assert that the accomplishment of this end completes its task. But later movements of the moral order have not been so distinctively the work of Puritanism. What we have begun to term the social conscience is wider in its sources and broader in its workings than the anti-slavery conscience. The prohibition crusade, for example, is of the South more than of New England. Economic crusades have their origin most frequently in the West. The Puritan conscience may be expected to go over into the national blend of moral forces, with the prestige and influence attending its accomplished results.

In the further estimate of the causes which affected the fortune of my generation, according to its place in the or- 
der of time, I put without hesitancy the incoming of the new social order consequent upon the rise of industrialism. This incoming of the new social order was in reality a social revolution, though lacking most of the usual signs of violence. For it was nothing less than the change from the individualistic basis of society to the collective basis, or, if we do not allow the political implication of the term, to the socialistic basis. And the change came, not in any way of evolution from the existing theory or state of society, but altogether through the compulsion of outer forces. Individualism, as a working theory of society, was overwhelmed and put to confusion by the vast output of the material forces, which had been set in operation by the discoveries and applications of science. True, individualism itself was a contributory cause in this material expansion, perhaps the greatest, because furnishing the necessary initiative. But whatever may have been the relative part taken by the agencies already at work, the situation which they created forced the change. The old order could not bear the strain of modern industrialism.

In view of the immense pressure of industrialism upon the social status, the result produced is often referred to as the industrial revolution. But this designation confounds one of the greatest of the causes of the change in the social order with the change itself, - the change, that is, from the individualistic to the socialistic conception of society. This revolutionary change reached far beyond the limits of industrialism. Still the results were most quickly and most extensively manifest within its limits. These were equally manifest in the changes wrought in each of the two great factors of industrialism, capital and labor. Capital rapidly passed from the hands of the individual into the control of 
the corporation, and thence into the control of the trust. Labor passed in like manner and with equal step from the control of the individual to that of the union, and on to that of the federation. Capitalist and workman alike placed themselves under self-imposed limitations. They allowed themselves to disappear as individuals to reappear as members of organizations. Business in general passed from the stage of individual contract to that of collective bargaining. The change, though different in its workings, soon became as marked in trade as in the industries. The individual trader gave way before the combination or the syndicate. The small shop was merged into the department store.

Meanwhile a corresponding change was going on in the attitude of men to their daily work. Work came to mean employment, and getting employment meant getting a place, or a position, according to the new grading of work. The effect of the change was very marked in the case of graduates from the colleges entering on a business career. The first years of effort were often years of experimentation, - the trying of one place after another to find, if possible, a fit. It was possible to make a place, as well as to find one, in the new and more rigid order, but it required greater power of initiative and invention, and especially of adaptation.

The political effect of the change in the social order has thus far been much less than was thought probable, much less in fact than might have been expected. The advance on the socialistic basis has stopped far short of socialism. Democracy is a very elastic term. It may mean representative government or, as nearly as possible, popular government. In Mr. Lincoln's analysis of democratic govern- 
ment as "of the people, by the people, and for the people," it is the second distinction only that is really concerned with method. The social revolution placed the political stress at that point, but it effected little more than a series of experiments in popular government. No radical change was carried out, and few were attempted. The Government has gradually become more socialistic in its working, without making any appreciable approach to socialism. I have referred to the new idea of place or position in the daily work. State socialism could mean nothing less than the formal if not arbitrary placing of men, the assignment of every man to his task. In this ultimate possibility, absolutism and socialism are not far apart in principle. It is impossible to conceal the fact that underneath the glowing promises of socialism, there lies the threat of a grievous tyranny, if the principle should be carried to its logical conclusion at the hands of an industrial democracy. In the momentous struggle now raging, it remains to be seen whether organized socialism is to be the ally of democracy or the tool of absolutism.

The religious effect of the social revolution was in some respects deeper and more far-reaching than the political effect. It changed the prevailing type of religion. Individualism had been the foundation of the Protestant faith, especially of Puritanism. Now men began to think in terms of social Christianity. "Even the Church," wrote Stanley Leathes in the introduction to "The Latest Age" in the series of Cambridge Histories, " even the Church has been infected; the modern priest is sometimes more concerned for the unemployed than for the unrepentant." This sarcasm hid a deep truth. Christianity had begun to concern itself with economic conditions. Poverty, if the 
result of unemployment, called for more than charity. The relief lay in social justice, a term which came into service to express the obligation of society to the unemployed or to the underpaid. New methods of meeting this obligation were adopted. Social settlements sprang up in the cities side by side with the religious mission and the charity organization. The Church became as conspicuously the agency for "social service" as it had been the "means of grace" in the work of individual salvation.

The social revolution has brought about very many changes, more numerous however and more varied than radical in character. On the whole they have been beneficial. They have made the return to a narrow individualism impossible. But it cannot be said that the social revolution has fulfilled the threat or the promise of socialism as an organized power. What is yet in store for the world under the extension and closer organization of socialism into internationalism, is one of the anxious questions attending the rapid development of class consciousness. Enough has transpired to show that communistic socialism proposes to occupy a political territory outside and beyond the limits of democracy. Democracy, as the expression of the will of the majority, can have no place for the rule of a conscious minority, the working tenet of Bolshevism.

Such was the fortune of my generation in respect to the time in which its lot was cast - a time of new and aggressive intellectual demands, of unfinished moral tasks, of widespread changes in the social order. As may be seen from this brief retrospect, it was not a time through which one could find his way clearly, either the way of knowledge 
or the way of duty. But it was from first to last, as I have said, a period of incentive and challenge. One felt all the while that he was living in the region of undiscovered truth. He was constantly made aware of the presence of some unsatisfied opportunity. When compared with the times which have burst upon us with such sudden and appalling fury, the times which $I$ have described seem orderly and undisturbed; but when at last the true perspective of history is reached, I doubt not that they will regain their natural place in the opening era of the modern world. 


\section{CHAPTER II}

\section{THE PERSONAL BACKGROUND}

\section{Ancestry and Early Home - School and College}

However clearly one may become conscious that he is in and of his own generation, he is for a time still more conscious that his point of view lies somewhere along the line of approach to it, through the family and institutional life of the past. My approach to my generation was through the New England home and the New England college. I am still conscious that these gave me not only the early point of view, but initiative, direction, and restraint. This fact of directive force is emphasized by those slight divergences from a common background which so often lead to such great variety, if not diversity, of result. At the reception attending the inauguration of Dr. Alderman as President of the University of Virginia, I was greeted with great heartiness by one of the older members of the Southern branch of my own family - "Well! how are you at last, my long lost brother?" That our family lines had not often run together when we thus met was due to a divergence back in the fourth generation, somewhere in the sixteenth century, when of four brothers who left the old home in Kent for the new world, one came by way of Bermuda, to which he had received a government appointment, from whom sprang the Southern members of the Tucker family - a slight divergence, but enough to spread the family lines in due time to either side of the breach of the Civil War. 


\section{ANCESTRY AND EARLY HOME}

The town of Griswold, Connecticut, where I was born July 13, 1839, in the little parish of Pachaug lying on the river of the same name, means more to me as the home of my ancestors than as my own birthplace. To borrow the euphemism, through which a quaint old friend used to put aside the actual place of his birth in favor of the place which he could identify by memory, "my conscious existence began" in the neighboring city of Norwich, to which my father removed soon after I was born. My grandfather Tucker whose name I took (having been born on the day of his burial) was the fifth in descent from Robert Tucker, who brought the family name from England in 1635 . Robert Tucker settled first in Weymouth, Massachusetts, and afterwards in Gloucester, and Milton, in all of which places he filled the office of recorder or town clerk. Early in the next century, his descendants came into eastern Connecticut, into what afterwards became the township of Griswold; and into this immediate region came the Lesters, the Morgans, the Coits, the Johnsons, the Tylers, the Lords, - families with which my own family came into close relationships. As will be seen from the names, these families were all of English origin. The population of this part of Connecticut was at this date, and for a considerable time, entirely homogeneous, with a single exception. There were not a few colored people. My earliest remembrance of persons is of my colored nurse.

The times in which the development of the country and the blending of families were taking place, were evidently prosperous and happy. The homes which still remain bear evidence of an abundant and hospitable domestic life. The 


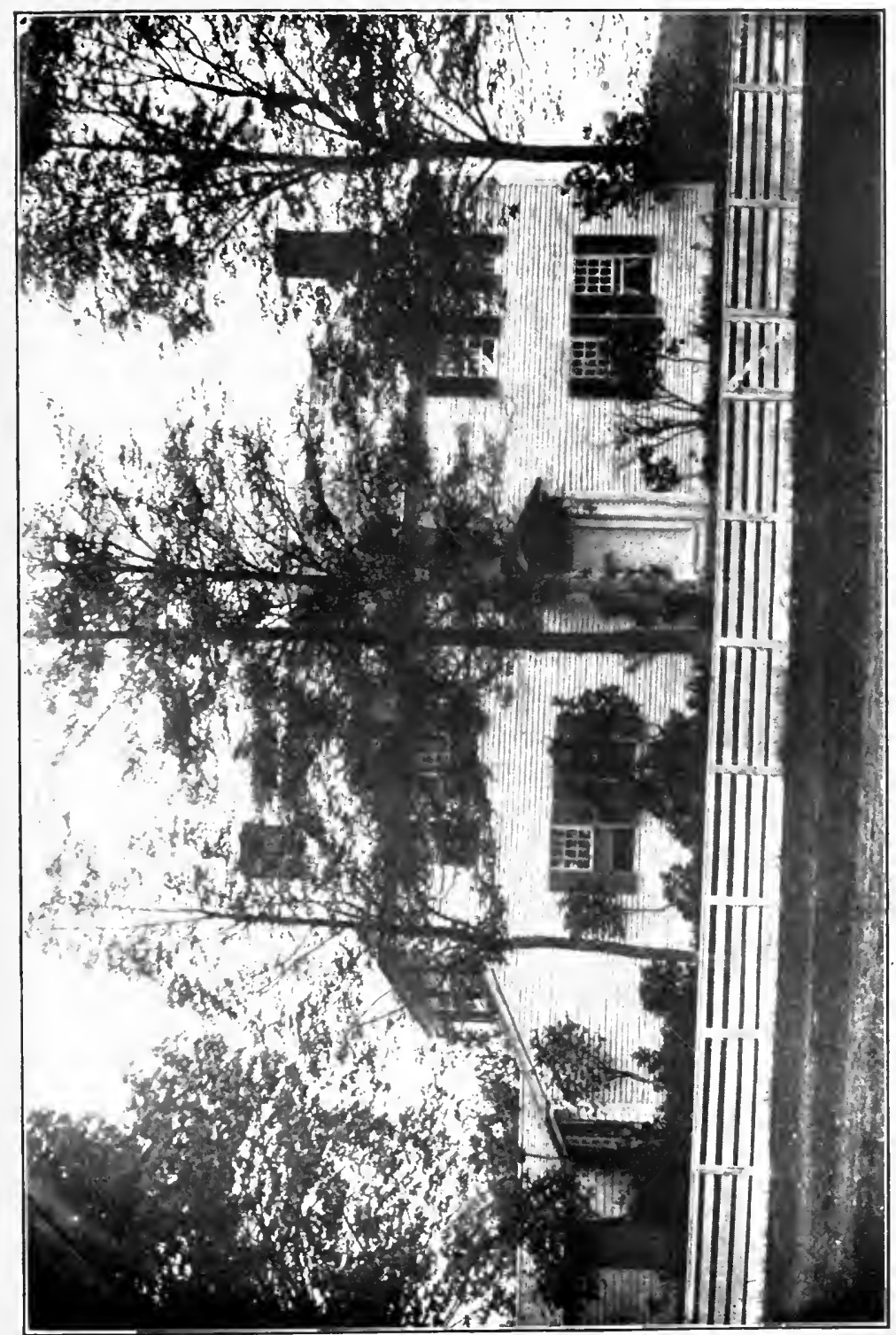

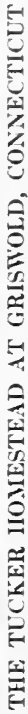



land was brought under close cultivation, judging by the size of the walled fields. The streams were beginning to be utilized for manufacturing. Jewett City, a village in Griswold lying on the Quinnebaug, grew up rapidly into a manufacturing community. Norwich, the center of trade and of social life in the region, was of easy access, and the Sound boats from Norwich brought New York within less than a day's journey. Even rural society had its conventions, as appears from the fact, of which $I$ have been directly informed, that as late as $\mathbf{1 8 4 0}$ families were seated in the village of Griswold church with due regard to their standing in the community.

My grandfather's house stood on the village green. It was of unusually good proportions, and ample for the uses of a family large in itself, and given to hospitality. One feature which especially delighted me in my early visits was the stoop - a large room open to the south, taking the place of a piazza, but offering better shelter from wind or sun. There was also a long ell, containing several extra rooms, among which was a separate housekeeping apartment. This arrangement was, in accordance with the provision of the time, for unattached women near of kin. In the present instance, it served as thehome of my grandmother's sister, known as Aunt Zerviah, whom I recall as a most vivacious old lady who knew how to add very much to the entertainment of a visiting boy. I have often thought that the custom in question must have been conducive to the self-respect of the occupant of such an apartment, and also in many cases to the harmony of large country households.

My grandfather was known throughout the region as "Squire Tucker," a title occasionally given by courtesy to some man prominent in affairs. Judged by his success in 
business, especially as a pioneer in manufacturing, he was a man of marked initiative and force of character. He was actively interested in politics, and at times represented the town in the state legislature. His diary shows him also to have been much given to introspection and reflection - a rather unusual association of natural qualities. He was devoted to his home, and interested himself personally in the training and education of his children. At the time of his death (at fifty-seven), the family consisted of my grandmother and six children - two sons and four daughters. My father was the eldest, and at this time was twenty-four years of age. He had been fitted for college, and had actually entered Amherst (in 1833), but withdrew to go into business partnership with his father and cousin. Soon after he married Sarah White, the elder daughter of Captain Joseph Lester, of Griswold. He was then twenty-two, and she twenty. I do not refer to this early marriage as representing the common age, though my mother's only sister was married at the age of eighteen to the young pastor of the village church, the Reverend William R. Jewett, of whom I shall have much to say. Within two years after my grandfather's death, the affairs in the home had been so far arranged, that my father was able to carry out his plan of making his home and business headquarters at Norwich, which thus became the home of my childhood, till the death of my mother in my eighth year. All my memories of that time and place are full of charm, and some of them are very clear. I recall distinctly my playmates - Charlie Coit, George and Dick Ripley, Bela Learned, Kirk Leavens, and Sam Merwin. I recall places with equal distinctness. Norwich was a town, in many of its local associations, to delight the heart of a small 
boy - the "landing" at the head of the Thames, formed by the junction of the Yantic and Shetucket, where the passengers of the steamboat train from Boston then took the boat for New York; the "little plain" where I lived, with Savin's Hill in the background carrying the jail of fearful suggestion just over its summit; the "big plain" a mile above at Norwich Town used as a muster field; the little shops at the landing full of boy's treasures; and the stately homes which even a boy's eyes could really see all these come back to me under the full charm of memory. There was one object above others which stirred my boyish sentiment and imagination - the then newly erected monument to Uncas, chief of the tribe of Mohican Indians, the faithful friend and ally of the early settlers, from whom came the site of the city of Norwich. It was Samson Occom of this tribe, whose application to enter Dr. Wheelock's school in the neighboring town of Lebanon transformed it into the Indian School which became the precursor of Dartmouth College. As a boy I knew nothing of this connection, but in these last years I have liked to relate this, among some other scenes of my boyhood, to my later work. My birthplace was within easy distance of the town of Windham, the birthplace of Eleazar Wheelock, the Founder of Dartmouth, and nearer still to Lebanon, the birthplace of his son and successor to the presidency of the college. As the ninth president of Dartmouth, the succession to the Wheelocks never seemed as remote and unreal to me as would doubtless have been the case but for these early impressions and associations.

The one grief attaching to these memories is the fact that I have so little remembrance of my mother. How much would I exchange for a satisfying glimpse of her face! Her 
portrait shows a somewhat sad face, but all who remember her speak of her great vivacity and good-humor, her alertness and courage, the freedom and fascination of her manner. Doubtless it is well ordered that the lesser things of childhood lodge most firmly in memory, but it may yet be true that the greater things really find their way into the unconscious influences which affect the whole after life. I can see that the two persons who have had the most effect upon my imagination were my grandfather, whom I never saw, and my mother of whom I have so little personal remembrance.

The death of my mother, followed by the subsequent breaking-up of the home in Norwich, brought about a very great change in the circumstances of my life. My later boyhood is associated entirely with the town of Plymouth, New Hampshire. I have referred to the marriage of my mother's sister to the Reverend William R. Jewett, then pastor of the church in Griswold. He had now become the pastor of the Congregational Church in Plymouth. Thither I was taken upon the death of my mother, for the time being, but, as it proved to be, for my permanent home. Upon the second marriage of my father some years after, and his removal to Sandusky, Ohio, and later to Chicago, I was informally, but in a very real sense, adopted into the home of my uncle and aunt, and the name of Jewett was incorporated into my own name. As might be supposed, the journey from Norwich to Plymouth was full of exeiting incidents, chief of which was the celebration of the introduction of the Cochituate water into Boston the day after our arrival there. My father, like most business men from eastern Connecticut, when a visitor in Boston, was a guest at the United States Hotel. That particular visit at this 
hotel filled my childish mind with wonder not unmixed with awe. I do not know what my thoughts would have been, could I have anticipated the fact that forty years later, this same small boy would be tried for heresy within these same walls, at a court extemporized in the old dining-hall of the hotel for the trial of certain Andover professors by the Board of Visitors. The railroad journey ended at Concord, New Hampshire, or possibly at Meredith Bridge, now Laconia, the remainder of the trip being taken by stage. As the heavily loaded stage came within a short distance of Plymouth, it "took fire," in the vernacular of the road, - a heated axletree, that is, set the wood casing in a flame - and so we entered the town. Could any entry have been more to the mind of a small boy!

Plymouth was a shire town of Grafton County, or more exactly a half-shire town, dividing the distinction with Haverhill. In the distribution of social and professional life throughout New England at that time, the proportion which fell to the shire towns far exceeded their relative rank in population. The towns chosen for county seats were usually of good traditions, supported by families of position and culture, and the courts brought to them a constant influx of legal talent. Jeremiah Mason and Mr. Webster were frequent attendants at the court held at Plymouth. The town also had the social advantage of its site at one of the gateways to the Franconia and White Mountains, detaining many travelers by the charm of its own immediate environment. Ex-Senator Blair, also an adopted son of Plymouth, has often said to me that his later knowledge of the country had shown him no town more representative of good breeding and good manners, 
instancing in proof the characteristics of some of the leading families of the time.

Of course, it would not take a boy with an inherent love of sport long to find his place among new playmates. But those whom I recall quite as well as my mates were some of the men who answered so well Phillips Brooks's designation of "boys' men." Such was one of our neighbors, the best fisherman in the region, who was always ready to tell us just where we could find the biggest trout, but always adding, "It's no use; they'll just sniff at your bait and say they guess they'll wait for Sam Rowe to come round." And they always did. Such, too, was Benjamin IVard, a little farther up the hill, the old cabinet-maker, full of the lore of quaint histories. Many an hour have I sat in his shop, listening with wondering ears to his tales of lost islands of the sea, and buried cities of the land. Such was O. H. P. Craig, - later Captain Craig, of the Sixth New Hampshire Infantry, - the soul of good-humor and manly sense, whose presence radiated so healthy an influence over boys, that I do not wonder that as young men they followed him in battle. And quite near by my home, where I was sent on daily errands, and where I was apt to stay much oftener on my own account, were Uncle and Aunt Noah Cummings, both equally entitled to the masculine Noah, the undisputed authorities on all neighborhood happenings. Of course every boy knew the stagedrivers, and was wise in his discriminations about the handling of the four-horse and the six-horse teams. Even when the coming of the railroad two years later transferred something of this wisdom to the names of the engines, and their respective capacities in speed and power, the stages held the center of interest so long as they controlled the way to the mountains. 
My early school days were passed chiefly in the "Academy" under its changing fortune of teachers; but the most unique experience was in a private school taught for several sessions in the Methodist vestry by Mr. Cass, a graduate of Wesleyan. Mr. Cass was very near-sighted, and had the still greater infirmity, for a teacher, of a passion for long and unusual words; but he knew how to teach in spite of his infirmities. No other teacher whom I ever knew could have called a school to order and actually achieved the result, in these words, "Let the school now preserve tranquillity."

In a like casual but very real way, every boy took his lessons at first hand, and without partiality, in the school of Nature. He learned the true meaning of its democracy. It was easy to fling the saddle on his horse, and take a morning or evening ride to "Prospect" for the view from Winnipesaukee to the mountains; easy to follow the streams with his rod, easy to take all winter sports, though at their price. I have never believed that the city boy, developed into the summer resident who takes Nature in her gentler moods, ever quite knows the meaning of what I have called the democracy of Nature - the rule of those great and masterful equalities which far surpass any democracy of society.

The village boys of my time were keen politicians. Early and late they attended the March meetings in the old town house, and were never disappointed if the meetings were prolonged into the second day. They knew the personal bearing of every vote. They were less surprised than many of their elders at the results of some elections. I can recall as if it were yesterday, the faces of some of the older Democrats of Plymouth on the morning following the first 
election in the "Know-Nothing Campaign." A caricaturist could have filled his notebook with telling sketches.

Boyhood in New England before the arrival of the modern boy does not suffer by comparison with later conditions. The things essential to a boy's life were there, not ready made for him in modern abundance and often bewilderment, but ready for him to shape to his own ends. He was well supplied with the materials, if not with the finished product. Village life of the larger type was not straitened in itself, nor was it inaccessible to the outer world. The knowledge of good and evil came early to the mind of an eager and curious boy. The poetic fancy of a secluded or sheltered life is a moral delusion. It was no easier then than now for a boy to endure the restraints necessary to right conduct. But the family training of that time did not stand primarily for repression. I should say that the prevailing note was freedom. The stage of overtraining had so far passed by that there was little sense of unnecessary restriction. The restrictions put upon a boy were for the most part such as were shared by his elders, like certain observances of Sunday. They belonged to the customs and conventions of social and religious life. The forms of religion were a part of the family routine, but its realities were no less a pervasive influence.

The education of the home was concerned with more than morals and religion. The home was the medium through which a great many educational influences reached the mind of a boy. It is a mistake to suppose that there was a dearth of interesting books. My uncle's library was that of a minister, but I found there just the kind of reading I wanted. "Robinson Crusoe," "Pilgrim's Progress," and the "Arabian Nights," all well illustrated, made the first 
appeal to the imagination. Then Scott's "Tales of a Grandfather" and the "Waverley Novels," and later Plutarch, and the more stirring biographies and histories and books of travel. Guests, no less than books, kept the home open to the outside life. They made their constant impression, and often with the most quickening effect. And above all, the personal element entered into the daily education. My uncle, to whom I go back with so much interest as well as affection, was not what I have called "a boy's man." He really did not know how to get into a boy's life, but he knew what was so much better, how to let a boy into his own life - and how roomy and hospitable it was! There were so many ways in which all unconsciously to himself he was a companion or a stimulating presence. He was an enthusiastic lover of the mountains, knowing them all within a wide range by name, and at home among them all. He was a charming conversationalist among his guests, and a genuine man among men at large, making it a pleasure to be by his side in the home or on the road. And he knew books that other people would have liked to know, and how to make them tell their own story through his unconscious enthusiasm, and his equally unconscious but very real strain of hero-worship. I am afraid that he let some very doubtful historical characters into company with the saints. He shared in the fascination which Byron cast over Lyman Beecher and some other ministers of the time, and never altogether forgave England for the banishment of Napoleon to St. Helena. His sense of humor was keen, but there was a delightful contradiction about it. He would shake his sides over Sidney Smith, but the reading of "Pickwick" could draw from him only a sympathetic smile. 
As I recall my own experiences in a Puritan home, and those of my mates, I have little sympathy with the men of my generation who attribute any subsequent license on their part in morals and religion to the strictness of their early training. The home life of that period as I saw it had found the normal balance between authority and indulgence. There were exceptions, but I am inclined to think that a good many of the uncomfortable experiences which linger in the minds of some men should be charged to the narrowness or temper or obstinacy of individual parents rather than to Puritanism. And due account should be kept as we grow older with the results of our own youthful mischiefs and follies. Whatever the Puritan home may have been aforetime I know only by report, but when it became the home for my generation, it stood for a natural, intelligent, and reasonably free approach to the world.

\section{SCHOOL AND COLLEGE}

In the decade which preceded the Civil War, as in the previous decades of the century, the college was the dominant factor in the educational life of the country. It was the higher education. The older colleges bearing at the time the title of universities were universities only in name, except through a loose association in some instances of one or two professional schools. The university idea, as I have elsewhere noted, did not really enter the educational system till the decade following the war.

The academy stood in like relation to secondary education. It was until late in the century the secondary school of the country. Dr. Harris, former United States Commissioner of Education, is authority for the statement that there were about forty public high schools in $\mathbf{1 8 6 0 .}$ 
Among these were a few notable ones, chiefly in New England, like the Boston Latin. But in 1850, there were over 6000 academies, with an enrollment of 263,000 pupils, and an annual income (including tuition) of $\$ 5,800,000$. The wide distribution of these academies created a great many small intellectual centers. They gave, until the public school system had produced the full quota of high schools, a certain educational advantage to the country towns above the cities. The catalogue of any New England college of the period will show a large percentage of students from country schools. Account, however, must be taken of students from the cities in attendance at these schools.

There was an almost absolute uniformity among the older colleges of the period, resulting in a corresponding equality in numbers and position. They all had the same educational aim, the disciplinary and cultural in distinction from the vocational. There had been a time when they might have been said to be highly vocational, viewed as training schools for the ministry, but that time was long past, and the newer vocations had not established their claims upon the colleges. I doubt if the ministry ever secured such concessions as have now been granted, for example, to medicine, by the allowance in many colleges of two years of the course to be reckoned for the degrees both of A.B. and M.D. I think that Senator Hoar in his reminiscences of life at Harvard (1842-46) ${ }^{1}$ underestimates

1 "I do not think Harvard College had changed very much when I entered it on my sixteenth birthday in the year $18+2$, either in manners, character of students or teachers, or the course of instruction, for nearly a century. There were some elementary lectures and recitations in astronomy and mechanics. There was a short course of lectures on chemistry, accompanied by exhibiting a few experiments. But the students had no opportunity for laboratory work. There was a delightful course of instruction from Dr. Walker in ethics and meta- 
somewhat the range of study then pursued in the colleges, but the discipline was strictly intensive. Even some years later, it did not reach beyond the ancient languages, mathematics and physics, with excursions into astronomy, logic and rhetoric, and philosophy and political science. "Electives" in the modern languages and experimental lectures in chemistry and geology hardly came within the scope of the college discipline.

The most remarkable omissions from the curriculum were of modern history and modern literature; but the explanation is to be found in the provision made for private reading in both departments. College libraries of that time were primarily reading libraries. They were known as society libraries and were largely maintained and managed by students. These libraries have long since been incorporated into the general college library of any given institution, but at the time of their active existence they were a great stimulus to reading. Students drew books from them up to the limit of their allowance, especially for use in the long winter vacation. I recall two courses in History which $\mathbf{I}$ carried on by myself in two successive years - one on the English Commonwealth, and one on Spanish conquests in America. It seems like a singular inversion in disciplinary methods that history and English literature are now made the subjects of as intensive study as any subjects in the curriculum.

The curriculum was a fixed quantity in all the colleges. This made the ready interchange of students entirely practicable; and as there were fewer ties binding a student to a physics. ... There was also some instruction in modern languages, - German, French, and Italian, - all of very slight value. But the substance of the instruction consisted in learning to translate rather easy Latin and Greek, writing Latin, and courses in algebra and geometry not very far advanced." 
particular college, the number of transfers was relatively greater then than now. But the chief effect of the fixed curriculum was to be seen within each college. It introduced and fostered competition in scholarship. It did not for this reason make scholars, but it converted a good many rather indifferent scholars into competitors. As all the members of a class were studying the same subjects at the same time, results could be compared according to the same standards. Hence a very general, and in some cases, a sensitive, interest in "marks." And this interest was kept alive by the fact that the daily recitation was chiefly oral, and before the whole class if, as was usually the case, a class did not number over sixty or eighty. There were limits to the degree of ignorance or stupidity which one liked to display before his classmates. The occasional sarcasm of a professor was of little account beside the instant and unanimous and hearty tributes of one's fellows to his mental lapses.

A common characteristic of the colleges was the predominance of the personal element in teaching. Not only was there little of an intermediate character in the way of equipment, but little account was made of the science or art of teaching. There was little of pedagogical training for a professorship. Not all professors had even served an apprenticeship by tutoring. The faculties were almost entirely made up of full professors. A freshman had the best a college had to offer, equally with a senior. There was thus a certain equality of instruction in each college and in all the colleges. Every college faculty had its well-recognized scholars and influential teachers. The conspicuous names which at once come to mind are distributed without preeminence on the part of one or two colleges.

As a result of this uniformity among the older colleges, 
there was a remarkable numerical equality. I had occasion to make comparison, at this point, among four of the older colleges during the period of seventy years between the close of the Revolutionary War, and the opening of the Civil War, with this result. I quote the comparison of two decades at the beginning, and two at the close of the period.

Number of Graduates by Decades

\begin{tabular}{|c|c|c|c|c|}
\hline & $1790-1800$ & $1800-1810$ & $1840-1850$ & $1850-1860$ \\
\hline Harvard........ & 394 & 440 & 632 & 870 \\
\hline Yale....... & 295 & 518 & 926 & 1009 \\
\hline Princeton. & 240 & 328 & 649 & 677 \\
\hline Dartmouth....... & 362 & 337 & 591 & 639 \\
\hline
\end{tabular}

A further result of the general uniformity among the colleges was the tendency to produce something of an educational aristocracy among college graduates. I use the term "educational" rather than "intellectual," because the colleges never included or developed the artistic quality; and I use this term rather than the term "social," because college life was not then tributary in any direct way to social distinction. The college man stood, however, in a distinct relation to the public. Much was expected of him. If he returned to his native town to "settle down" he met with a certain contempt. It was expected of him that he would make his way into the larger world. I think that his own consciousness accorded with this expectation. Something of the traditional spirit of the English colleges in their relation to public duty came over by inheritance into the earlier college training in this country, and made itself felt in a like "call to account very strictly to the world for such talent or power as a man may have."

When I entered Dartmouth in 1857, I was much better prepared to pursue the course of study than to understand 


\section{THE PERSONAL BACKGROUND}

this moral significance of a college training. Largely, I suppose, by my uncle's choice, but also because of the good fortune of an unusual Latin instructor in the local academy, I began Latin at an early age, so early that I never had occasion to study English grammar. Preparatory Greek I studied for a much shorter time, but under thoroughly competent teachers, at Kimball Union Academy, the most popular fitting school for Dartmouth at that day. Mathematics received scant measure among the three requisites for college entrance, reduced still further in my case by personal restriction. I recall very clearly my examination for college. It was made up of a succession of individual, oral interviews, conducted by the professors in charge, in their private studies. A certain fluency in reading from one or two of the prescribed Latin authors brought from Professor Sanborn, who was little inclined to waste any unnecessary time in so tedious a business, the abrupt but pleasing remark - "Well, there is no use in eating a joint of mutton to tell whether it's tainted or not." The examination by Professor Putnam in Greek was much more critical, but confined chiefly to the grammar, in which I had been well drilled. The examination in mathematics brought me to the study of Professor Ira Young - father of the celebrated astronomer - just before the dinner hour. I had hardly been seated and put at work upon a problem, before the dining-room door opened and dinner announced itself. After a little, the professor asked me how long it would take me to finish my work. I replied (truthfully) that I could n't tell. He quickly made his own calculation, asked me a few general questions, and closed the interview. The alternative was evidently a cold - a very cold - dinner.

In the college curriculum of the first two years there was 
little change from the studies of the preparatory school. The change was altogether in the surroundings, in outward conditions, in atmosphere, in the tone and spirit of the common life. It was a change into a world of freedom, of individual responsibility, of constant stimulus. As I have said, I was not prepared for this larger and more stimulating life. The restrictive discipline of the preparatory school, doubtless necessary, especially in a coeducational institution, had repressed certain natural ambitions, and developed in their place a good many wayward tendencies. I entered college in a somewhat restive and assertive mood, disposed to use the new freedom for whatever college life had to offer. But I miscalculated its moral effect. The new freedom wrought its own transformation. It effected with surprising rapidity a change of disposition and temper, and thus gave to the various objects of college pursuit their chance according to their value. I found that the suddenly acquired sense of responsibility produced a new and unexpected zest for the essential business of the college, and gradually opened a true perspective into the essential business of the after life. Without hesitation, I date the beginning of any really responsible purpose or ambition from my entrance upon college, and ascribe the change to the complete readjustment of desires and purposes which then took place.

This moral effect of the college atmosphere and environment was steadily supported by the college routine. The college acted constantly through its totality. Whatever it had to offer intellectually or morally, it brought to bear in its unity upon every student. The modern college individualizes its subject-matter and in degree, its discipline. The elective system has its own moral effect. It naturally 


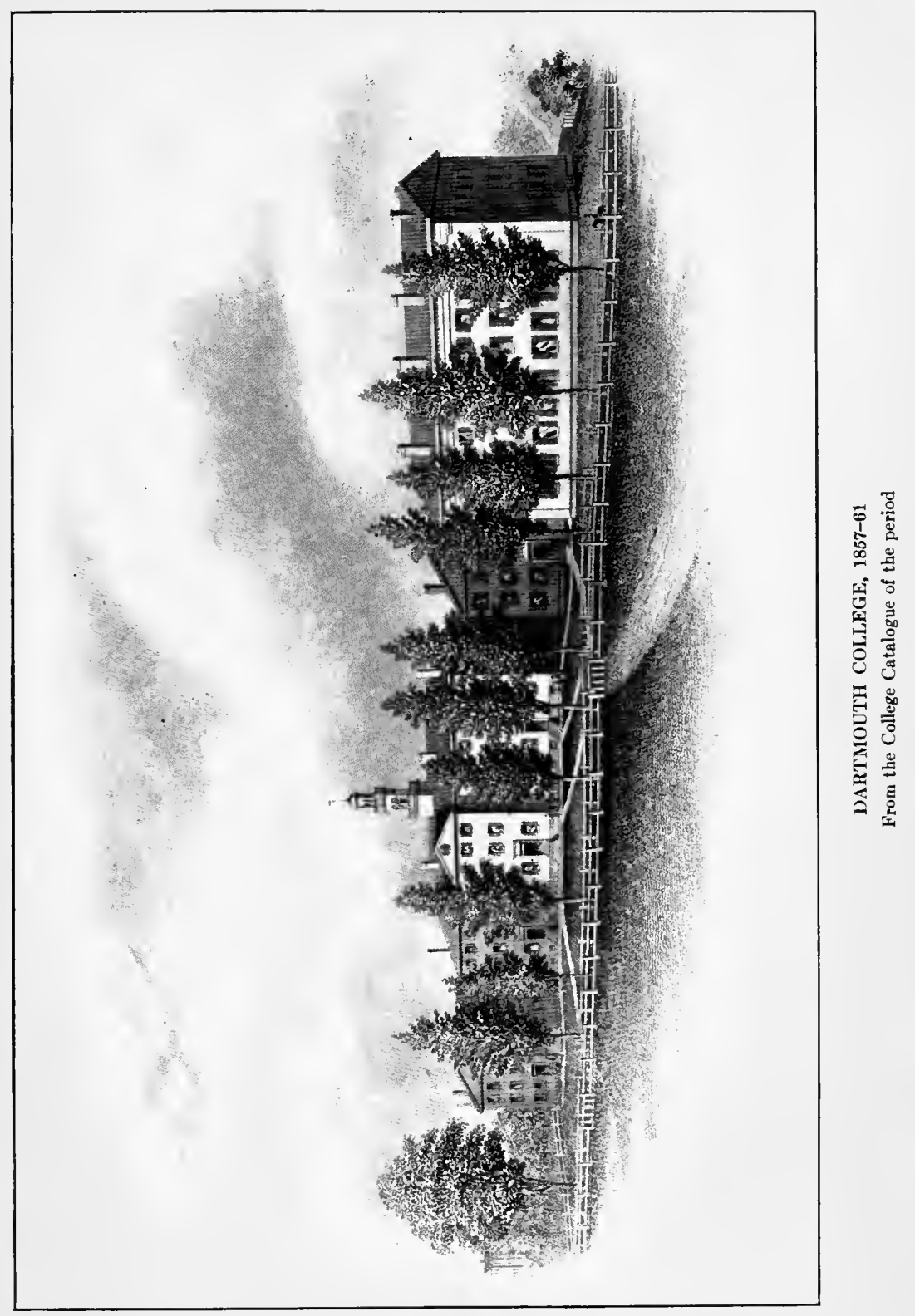


. 
tends to the development of responsibility. It also tends to much immature criticism, to much questioning of the value of any course once chosen, which does not produce immediate results. There was little questioning of the value of individual parts of the earlier curriculum. The whole curriculum was accepted in its entirety, and because of its entirety. It was the whole that counted as a whole, not as the sum of individual parts, the end in view being mental enlargement more than mental furnishing. Modern education assumes that mental enlargement is best effected through careful regard to the mental furnishing, and that the element of choice is therefore the main factor in mental discipline. The contention is so far true, that we are right in committing the modern college, under proper safeguards, to the fortune of the elective system, but it is impossible to overlook or minimize the effect which was produced through the earlier college by concentrating attention upon the end, rather than upon the divergent means for reaching it. As John Morley has remarked in a recent note of warning on the tendencies of modern education - "The business and the effect, the splendid effect, of universities is not merely to spread the reading of books, not merely to give knowledge, but to bring students to form habits of mind."

A further misconception of the effect of the earlier college training lies in its assumed impracticability. It is true that the classicist has fallen out of the race for practicality, just as the scientist for a time yielded place to the economist. The goal of practicality is a "flying goal." In its own time, the classical college was a broad and direct means to what were at the time practical ends. Before the educational approach through the sciences, the study of ancient 
history was the educational gateway into the living world. It opened into the broad area covered by the operations of Church and State. The historical method preceded for practical uses the scientific method. History as then understood was the science of human affairs. Classical study was the study of history far more than the study of language. Where one student learned to write good Latin, or to form his English style on classical models, ten were incited by their studies to read history, to take interest in the movement of events, to study men. The classical college trained men not away from their kind, but for those services and conflicts which were most distinctively human.

As I compare my recollection of the earlier college with my more intimate understanding of the workings of the modern college, I note as the essential distinction that the college of the earlier type was organized around the idea of unity: the modern college is organized around the idea of intensiveness. The old-time faculty was a group of scholars of similar training, and pervaded by a common educational purpose. Each professor was usually a man of marked individuality, but his individuality was in and of himself, not a reflection in any considerable degree of his training. A modern faculty is a body of specialists, or, to use the still more modern term, of experts. In like manner, the old-time curriculum was constructed with a view to the interrelation of its parts, and their mutual relation to the whole scheme. The modern curriculum is constructed with a view to the largest possible development of each separate subject, a purpose made practicable through the elective system. The effect of this set of the instructor and of the curriculum toward intensiveness, is to carry the individual student, whom it reaches, farther on his way to 
a specific goal. But under this dominating influence the modern college parts company more easily with the average student. Scholarship below the line of advanced work is on the whole more desultory and less cumulative. ${ }^{1}$

This general tendency or drift of the college in its educational policy has gone over into what is termed "college life." Intensity not unity is the aim of college activities. The distinctive college athlete in any department is a specialist. $\mathrm{He}$ is as much disconnected from his fellows as is the specialized scholar. I note this fact, not to decry specialization in scholarship, but to show that the principle, when put at work seriously in the higher ranges of college effort, will find its way into all departments of college activity. It is very difficult to urge the principle with the same men in certain directions, and to curb it in other directions. The working-out of the principle creates a college habit of mind and establishes its own standards of excellence.

In the midst of the changes in the general influence of a college upon its students through changes in educational policy one element in college life remains constant - the element of comradeship. The public is often surprised at the testimony of public men of high intellectual character

1 The more recent tendencies in academic education, the result in part of the war, have been interpreted by some as a return to the college of the earlier type. This is a mistaken interpretation. Such a return is impossible; it would be undesirable. That "totality" of impression, to which I have referred as the resultant of the earlier college, belonged not only to the small college, but to the day of the small college. What is now taking place is an advance in constructive unity, made necessary by the amount of subject-matter crowding the college curriculum, and also by the public demand upon the college graduate for a more responsible sense of the advantage of his training. This is the meaning, as I interpret the process now going on, of the attempt to construct a more highly organized and more closely interrelated curriculum; of the introduction of certain courses in the interest of citizenship or of the public welfare, to be taken in common by all students; and in the proposed requirement of a comprehensive final examination to guarantee some understanding on the part of the college graduate of the significance of the college course as a whole. 
as to the value of their college associations. Some under the influence of sentiment put this value above that of their college discipline. The value of these, however, when due allowance is made for sentiment, is very great. Comradeship is more than ordinary companionship. It represents one's holdings in the stock of common ideas and purposes. It represents that sense of security and trust which is born out of well-tried friendship. It represents that spirit which declares itself in the common response to a call to adventure, or to a summons to duty. Whether so recognized or not, it is that underlying and abiding element in the college inheritance, which makes our colleges the recruiting ground for great causes. Richard Hovey has not missed the mark in lis interpretation of college life in its deeper intimacies, and its irresistible incentives, as a "comradeship"; and this feature seems to be permanent and self-perpetuating. 


\section{CHAPTER III}

THE ENVIRONMENT OF THE CIVIL WAR

A tablet in Webster Hall at Dartmouth, similar to many in college halls throughout the country, bears this inscription:

UPON THIS TABLET ARE INSCRIBED THE NAMES OF
THE SONS OF DARTMOUTH WHO GAVE THEIR LIVES
IN THE WAR FOR THE PRESERVATION OF THE UNION
TO WHICH ARE ADDED IN RECOGNITION OF THEIR
PERSONAL DEVOTION TO DUTY THE NAMES OF THOSE
WHO FELL IN THE CONFEDERATE SERVICE.

Then follow in the order of classes the names of those who fell in battle - a few from earlier classes, but by far the greater number from the classes graduated just before or during the progress of the war. As was natural, the burden of the war in its claims for active service rested upon the incoming generation. An accredited press correspondent has recently stated that "the average age of all who fought in the civil war was somewhat under twenty-two years." The glory of the conflict was no more theirs than of their elder comrades, but the pathos of it was theirs. They knew life only in its beginnings and at the end.

$$
\begin{aligned}
& \text { "Dawn was theirs, } \\
& \text { And sunset." }
\end{aligned}
$$

They had no intervening day.

No one can recall his early associates, whose heroism brought them to untimely death, without a feeling akin to reverence. Neither can one mingle with his early associates who survived the war, but with whom he had no equal 
share in the great comradeship, without the constant reminder, however unconscious they may be of the difference, of their superior fortune. It has been a lifelong regret to me that I was precluded by a succession of prohibitive conditions, beginning with the disability resulting from a prolonged attack of typhoid fever, ${ }^{1}$ from any active part in the war till near its close, and then only in a subsidiary way. But I have sometimes thought that because of this experience I was made more sensitively aware of some of those phases of the ordeal of war, other than that of battle, through which a generation passes which is subjected to the searching realities of war. For the ordeal is varied and inclusive. It arrests the daily life at every turn, it changes the order and movement of familiar events, it creates communities of suffering and sacrifice, and above all it tests every man's spirit in his relation to his country and to the cause which may be at stake.

Unlike the present war, the Civil War was not unforeseen or even unannounced. For years the country had been living under the shadow of it. The title of a widely read book was "The Impending Crisis." The Civil War was in no sense "unbelievable," "unthinkable," - the terms in which we denied to ourselves the possibility of the present

1 This sickness made a peculiar and lasting impression on me. It was so severe and so prolonged that it seemed to me like a withdrawal from the physical world. I was too weak for most of the time to take any conscious part in the life of the sick-room or to help myself. The sense of utter helplessness was the one feeling by day and night. I do not recall that I had any fear of dying, or thought much about death. But the world seemed to be very remote. 1 was quite detached from it. All this was so real that when I came back to the life about me, it seemed like the entry into a new world. Nature had changed, and friends. 1 looked upon people with different eyes. They seemed more real, nearer, more intimate. As I look back upon the mental and moral effect of this sickness, it seems like a new interpretation of human nature, a kind of educational course in the real humanities. 
war. It was rather seen to be inevitable, and yet its approach was none the less unrealized on the part of the North, and when it came it found the Government totally unprepared. Secretary Seward's prediction of a ninety days' war may have been made partly for political effect, but it represented an influential body of opinion in Government circles, apart from Mr. Lincoln, whose sense of the meaning of the struggle was more truly prophetic.

The unreadiness of the nation naturally created a widespread feeling of impatience. An unmilitary people, fired with a great moral purpose, could not understand the delaying requirements of military organization. The cry of "On to Richmond" was taken up long before the Army of the Potomac was ready for the campaign, and when the first campaign ended disastrously, not altogether due, however, to a forced initiative, the popular impatience was increased rather than diminished. Measured by the time required for the creation of a modern army out of civilians, the organization of the Army of the Potomac was effected with reasonable speed. McClellan was a superb organizer, in this regard the Kitchener of the Civil War. In spite of his failure before Richmond, the nation was indebted to him for the army which under more determined leadership finally entered the capital of the Confederacy.

Perhaps the greatest trial to which the North was subjected in the early stages of the war was that of disappointment in its cormmanding generals. This was in marked contrast with the steady confidence of the South in the generalship of Lee. The rapid succession of commanders of the Army of the Potomac was disheartening. After McClellan - Pope, McClellan again (battle of Antietam), Burnside, Hooker, and Meade - all within a year. The 
loss at this time to the South of Albert Sidney Johnston and "Stonewall" Jackson was serious, but it was different in its moral effect. It was not till the turn of the tide at Gettysburg, with the coincident surrender of Vicksburg, that the heart of the North became more assured. The second stage of the war under Grant and Sherman had its own vicissitudes, but no like disheartening uncertainties. It became what would now be called a war of attrition.

However, before the change in the military conduct of the war took place the political situation had become serious, and continued to be till the end. The Emancipation Proclamation, issued after the battle of Antietam, accentuated the difference between the political parties of the country. To those who followed the lead of Vallandigham and like obstructionists, "war for the Union was abandoned; war for the negro openly begun." In the judgment of Mr. Lincoln, emancipation had become a military necessity, indispensable to the preservation of the Union. To the extreme radical, the preservation of the Union was the subordinate issue when compared with the abolition of slavery. There was likewise a division of sentiment among the supporters of the Administration - Republicans and War Democrats - regarding the measures to be taken for the restraint or suppression of compromisers and obstructionists. The margin of freedom, whether of speech or of the press, is necessarily narrow in times of national peril. In certain cases, the circumstance may make that dangerous or even treasonable which was not such in the intention. The Government too, sensitive to its responsibilities, may become nervous and overwrought under continued strain. The days which followed the disastrous defeats at Fredericksburg and Chancellorsville 


\section{ENVIRONMENT OF THE CIVIL WAR 45}

were days of peculiar trial. It was not strange that drastic measures were adopted to repress compromising and disturbing activities. At this distance, the arrest and subsequent banishment of Vallandigham, and the suspension of the "Chicago Times," seem to have been unwise if not unnecessary, but the aggravation was very great.

I was at this time in Columbus, Ohio, and though engaged in teaching, was otherwise brought in various ways into direct contact with the current movements in the political field. Columbus itself was on the dividing line between the earlier reservations, set apart especially for emigrants from Connecticut and Virginia, known as the Western Reserve, and that of the Little Miami. My home was for the time in the family of Judge Miller, of the Probate Court, a Virginian from the Shenandoah Valley, "a gentleman of the old school" in manners and dress, even to the wearing of a queue. His sympathies were naturally somewhat divided, but his loyalty was unimpeachable. His only surviving son, a captain in the Union army, fell at Murfreesboro. Many of the lawyers of the city were frequent callers at his home, some of whom were taking an active part in political affairs. As one born with the New England traditions, I listened eagerly to their conversation. The main subject was the arrest of various persons on the charge of "giving aid and comfort to rebels." Columbus was one of the centers of the Vallandigham Democracy, but the frequency and extent of the arrests brought many War Democrats and some Republicans into sympathy with this branch of the party. Whenever a free government begins to take repressive measures for the national safety, it is comparatively easy to organize a party under the cry of liberty and personal rights. A great many persons are 
sure to lose their sense of proportion in such a crisis. They would rather see the larger cause of liberty endangered if not defeated, than to see any infringement of personal rights and liberties. The revolt against the Government on the part of many loyal citizens in Ohio was so great that the result of the impending State election was for long time in doubt. It was a very great, but most unexpected relief when the election of Governor Brough by a majority of over 100,000, placed the State firmly in support of the Administration.

The issue of personal rights versus the national safety was soon followed by another issue still more demoralizing, namely, that of a premature movement for peace based on compromise and concessions. The criticism of the Government, to which I have referred, was accompanied, and in part sustained, by the sense of weariness and discouragement as the war still went on without decisive results. To such an extent had this feeling developed, that when the Democratic Convention met in the summer of '64, the convention was emboldened to pass a resolution, prepared by Vallandigham, based on the assertion of "four years of failure to restore the Union by the experiment of war," and calling for a "convention of the States or other peaceable means" for the restoration of the Union. Horace Grceley was equally urgent for immediate peace, and sought to bring about specific negotiations - a movement which called out Mr. Lincoln's very definite and very decisive statement of the terms of peace. "To whom it may concern: Any proposition which embraces the restoration of peace, the integrity of the whole Union, and the abandonment of slavery, and which comes by and with an authority that can control the armies now at war against the 
United States, will be received and considered by the executive government of the United States, and will be met by liberal terms on other substantial and collateral points, and the bearer or bearers thereof shall have safe conduct both ways." I have been led to quote this statement partly that I may bear witness to the comfort and strength which it has given to me at the time of writing, under the demands from so many sources for peace without definite and decisive results. And yet it is but fair to recall, in spite of this just and conclusive statement on the part of Mr. Lincoln, the dissatisfaction with him personally as well as with the Administration, which then pervaded the country. In the light of the present universal feeling toward Mr. Lincoln, it seems impossible that such a state of feeling could have existed. But such was the fact. As I recall those days of confusion and distrust, I cannot remember that any one really thought of Mr. Lincoln or felt toward him, as every one now thinks of him and feels toward him. Many despaired of his reëlection; some openly preferred the election of some other man; here and there a man, like Salmon P. Chase, did not hesitate to allow the consideration of his name as a candidate. There was a time when Mr. Lincoln himself so far doubted the possibility of his reëlection that he wrote the now well-known but then private memorandum: "This morning, as for some days past, it seems exceedingly probable that this administration will not be reëlected. Then it will be my duty to so coöperate with the President-elect as to save the Union between the election and the inauguration; as he will have secured his election on such ground that he cannot possibly save it afterward." Happily for the country, South as well as North, his fears were not justified by the 
result, but his own state of mind, reflected in that of so many of his personal and political friends, shows a phase of the ordeal of war which can hardly be surpassed by the ordeal of battle.

In the spring of 1864, having then entered Andover Seminary, I obtained leave of absence for service in the United States Christian Commission, and was ordered to report at Nashville, the headquarters of the Army of the Cumberland under General Thomas. The United States Christian Commission and the United States Sanitary Commission were the two links between the army in the field, and those at home most directly and personally concerned in their welfare. Of these two Commissions, the former was perhaps the more strictly personal in its work, relying less upon supplies, but each coöperated with the other, especially in the hospitals and on the battle-fields. Its policy, as I have said, was to keep the moral forces of the country in the closest and most helpful relation with the men in the field. With this end in view, the men under its direction were pushed as rapidly as possible to the front, and distributed among the regiments rather than assigned to specific regiments. Nashville was a base for army supplies and a site for base hospitals. The center of active operation for the western Army was Chattanooga, where General Sherman was engaged in reorganizing and consolidating the Armies of the Cumberland, the Tennessee, and the Ohio, in preparation for his march to Atlanta. After a short term of office work and hospital visitation at Nashville, I was sent with others of my group to Chattanooga, where our work began with the men in the encampments.

Any section of an army seems at first to be inaccessible to individual and personal approach. It seems impossible 


\section{ENVIRONMENT OF THE CIVIL WAR 49}

to individualize men so completely organized, or to reach them in unorganized groups. But nothing according to my experience could be farther from the fact. I found that the human approach could be counted upon to reach far among men, and to "find" them. The opportunities before the Christian Commission were constant and varied - in some cases to supplement the regular agencies at work, in more cases to take the initiative, so great was the need of service especially on the march and in battle. A few entries from my diary at the front, the record only of a few consecutive days, may give a better idea of this need than any general statement.

Sunday, May 8. With General Howard's Division on the march to Atlanta. Uncertain at what hour march would be resumed. Morning service with 88th Illinois, a very attentive audience. Had hardly finished speaking when general call was sounded, taken up by the Brigade; in fifteen minutes tents down and troops in marching order; two miles to Rocky Face Ridge, found there fifteen men of 125th Ohio wounded in morning skirmish; staid with them till dusk, then went on with ambulance train to Tunnel Hill. Coffee on the road with $2 \mathrm{~d}$ Missouri, Dutch Regiment.

Monday, May 9. Forenoon assisting in care of wounded: afternoon attended funeral of Simeon Carter, one of the men for whom I had written to his home just before his death; night till one o'clock in dressing wounds, 20 cases.

Tuesday, May 10. Up at half-past three to help in moving wounded to train - through the day with brief intervals in dressing wounds of men from the field.

Wednesday and Thursday, May 11th \& 12th. Both days at hospital. Very little complaint among wounded, enduring of pain remarkable. Occasional criticism from officers who suffered from frontal attacks made as at Rocky Face Ridge which seemed to them needless, but which were deemed necessary to hold the enemy while flanking operations were going on. (The direct as- 
sault at Kenesaw Mountain was the only move in this campaign for which Sherman has been criticised for substituting direct attack for a flanking movement.)

Friday, May 13. Started at seven on march from Tunnel Hill. Confederate entrenchment evacuated so hastily in night that we breakfasted on hoe-cake left before the fire and still warm. The dead still lying along the heights stormed by Hooker's Brigade. Marched fifteen miles and camped for night with wagon train without pitching tent.

Saturday, May 14. On the road to Resaca; battle opened at noon; was stationed where could see the troops deployed in immediate rear of battle-field. Casualties increased as the day wore on, and were severe on the following day. At first wounded cared for on the field, but later in hospitals in the rear. In the night sent back to the field as it was mistakenly thought that the first entrenchment had been carried; at work according to need on the field or in the hospital.

On the march from Atlanta to the sea the work of the Commission was suspended. My comrade on the earlier march (Lloyd, of Cincinnati) and I carried a dog tent between us which we pitched at night, unless we found other quarters. Naturally our main service was in the field hospitals, but there was still occasional opportunity for meeting with groups of the men in the evening encampments. Serious, and at times heartrending, as the work was among the wounded and dying, the services in the encampments were often strangely impressive. As I recall them I am reminded of the singular truthfulness of the lines in the "Battle Hymn of the Republic":

"I have seen Him in the watch-fires of a hundred circling camps; They have builded Him an altar in the evening dews and damps." 


\section{CHAPTER IV}

\section{THE PROFESSION OF THE MINISTRY}

THE ordeal of war produced a twofold effect. The war was carried on, so far at least as the North was concerned, with a heavy heart. It was a civil war, of which fact there were constant reminders. There was an entire absence of those incentives or excitements which attend a foreign war. The Civil War was purely a war for the national preservation and the national purification. As Mr. Lincoln saw it, it was a war for the national preservation through the national purification. In his own words - "This Government cannot endure permanently half slave and half free." But this cleansing task, though of the highest ethical meaning and in this sense inspiring, was like all things of the nature of chastisement, "not joyous but grievous." There was little of the glamour of war about it. The war did not engender the military spirit. Far more of this spirit had been kindled by the Mexican War. The heroes of that war, Scott and Taylor, were preferred as presidential candidates to statesmen of the order of Mr. Webster. General Grant was in due time chosen to the Presidency, not under reflected light of his victories, but in the confidence that he, better than any other man, could be trusted to carry out the general policy of Mr. Lincoln. General Grant, though a great soldier, and only by the necessities of the time and by slow training fitted for political duties, was essentially a man of peace. In this respect he was a true representative of the nation. The victories which brought the war to a successful close were not hailed in the spirit of triumph. 
There were no prolonged celebrations. The nation proceeded at once to disarm itself. A million soldiers made haste to return to the duties or the plans they had relinquished on the call to arms.

On the other hand, there was a deep and abiding sense of satisfaction that the task which had been undertaken had been thoroughly accomplished. There had been no premature or indecisive peace. The outcome was not a compromise. The nation emerged from the war no longer "half slave and half free." The unity of the nation had at last been achieved and insured. The country had become to the knowledge and in the sight of all the people one and indivisible. The change from a sense of fear to a sense of security gave a new significance to the national life. The integrity of the nation made a new and far-reaching appeal to the imagination of the people. They saw the nation not only in its wholeness, but also in its vastness - the vastness of its unpossessed lands and undeveloped resources, the vastness also of its human and spiritual possibilities. The mind of the nation turned with relief from the dominating issues of the war, and with a certain impatience from the task of political reconstruction, to enter upon the realization of the alluring and well-nigh unlimited opportunities now before it. The era which followed the war was distinctively an era of expansion, visible in the increase of immigration, in the advance of the agricultural frontier, in the extension of railroads, in the rise of new industries, and in the evolution of the industrial classes. The expansion of the more spiritual life of the country took place more slowly. It could not be seen so readily, but it could be felt.

Naturally so great a change in the national outlook 
brought about many changes in personal careers, especially with those who were within the period of the final choice of a business or of a profession. This period now became a season of reappraisals and revaluations in the light of newly awakened ambitions, or of more decisive appeals of duty. As it was at this point that the directive influence of the generation upon individual choices and plans began to assert itself, I call renewed attention to the fact of this influence, that the subsequent course of many individual careers involving unexpected changes may be understood. Changes which might otherwise be attributed to mere opportunism as a guiding principle, have their explanation in this directive and dominating influence which $\mathbf{I}$ am emphasizing. A man could not make himself most effective or most serviceable without constant regard to the direction of the forces which determined the movement of his time. There never was a generation in which the small consistencies of men counted for so little as against the insight and the courage to take the path of progress.

The personal change in my own case in the choice of a profession was from the law to the ministry. While in college, my interest was in those courses which had a bearing on law. The subject assigned me by the faculty for commencement was "The Obligation of the Country to its Jurists." This predilection toward the law was, however, more indicative of my interest and ambition than of any definite or well-considered choice of a profession in its relation to public duties. Doubtless the moral effect of the war upon others who had chosen the law, was to confirm them in their original choice, and upon others still to lead them to make the law their choice. Certainly the law in itself can never fail in its appeal to the sober and unselfish 
judgment of men. But to me it seemed, upon reflection, that the ministry stood for the time being in closer relation to what may be termed the personal element in professional service. Nor do I hesitate to add that the field of opportunity which it then offered seemed to ke wider when given its full range. The moral necessities of the situation made their own appeal to the imagination, and taken in connection with the new stirrings of thought, carried the appeal over into the region of intellectual adventure. I am still conscious that the call to the ministry, as I then interpreted it, lacked some of the usual motives. It was not the conventional call of the Church. But it took account of certain moral and spiritual values which were not then emphasized in the creeds, and which had little recognition within the sphere of organized religion. It was a call, though imperfectly apprehended, to that larger ministry which was soon to find its place within the scope of modern Christianity.

I think that this wider interpretation of the call to the ministry must have been in the mind of many then entering the profession, judging by the subsequent careers of some of my immediate associates in Andover Seminary. In my own class, several have carried their activities beyond the range of the pastorate, - Archdeacon Allen and Dr. Waldron, of Boston, the former of the Episcopal City Mission and President of the New England Watch and Ward Society, the latter Superintendent of the City Missionary Society and Chaplain of the Massachusetts House of Representatives from 1879 until his death; Samuel W. Dike, founder and Secretary of the New England Divorce Reform League; and four college presidents, Francis $\mathbf{H}$. Snow, of the Univcrsity of Kansas, James G. Merrill, of 


\section{THE PROFESSION OF THE MINISTRY 55}

Fiske University, John H. Morley, of Fargo College, and myself; and outside my class, but in the group of intimates, men whose range of thought was wider than that of their professional training, as George $\mathbf{H}$. Palmer, of Harvard, John H. Denison, of Williams, Cecil F. P. Bancroft, of Phillips (Andover) Academy, Newman Smyth, and Joseph Cook.

Andover Seminary was at this time in a peculiar sense a theological school, not a school of Biblical or historical criticism like the German schools, nor a school of ecclesiastical dogma like Oxford, nor like the unorganized "school" of liberal thought in which Maurice, Kingsley, and men of their type were the unaccredited teachers. Established to modify the influence of an extreme Calvinism, and at the same time to counteract the spread of Unitarianism, it necessarily developed a controversial attitude. It also developed, as a result of its theological holdings, a strong missionary spirit. The oldest and most influential school of theology in New England, it had gained more than local influence through its chair of Christian Theology, then occupied by Professor Edwards A. Park. It was the custom in those days for students in medical and theological schools to shift from one school to another, attracted by the fame of the superior teachers, often remaining but one year in a given school. The lectures of the Professor of Christian Theology occupied the entire time of the middle year in the seminary curriculum. As theology was treated by Professor Park, the lectures became the attraction and stimulus of the seminary course. I can hardly go farther and affirm with equal assurance their inspirational quality. The stage of earnest controversy had passed. There was little to fear theologi- 
cally either from extreme Calvinism or from Unitarianism. But the controversial form of statement still remained the best form for logical and rhetorical effect. The essential tenet of the Andover School - at once the liberalizing and the sobering influence of its theology - was the freedom of the human will. This tenet was reasoned by Professor Park with great ingenuity, with no little sarcasm at the expense of opponents, and often under a moving consciousness of the practical effect of the holding of the tenet upon human action and destiny. The will was divided and subdivided according to its moral responsibilities, and according to the results of its choices. There were the ordinary choices, there were "primary choices," there were "predominant choices," and there was the "primary predominant choice," which if right, the man was right here and hereafter.

"Mr. Blank," said Professor Park one day to a supposedly obtuse student, "if Peter had died when he was cursing and swearing, where would he have gone?"

"Gone to heaven, Sir."

"Doubtless," replied the Professor, somewhat taken aback by the promptness of the answer, "but how would he have gotten there?"

"Got there on his primary predominant."

The name of Professor Austin Phelps is always associated with that of Professor Park in recalling the Andover of the period. They wrought together, the latter in the chair of Homiletics (or "Sacred Rhetoric"), for thirty years in a remarkable professorial partnership, to which it was generally assumed that Professor Phelps contributed the more spiritual element. But spirituality is difficult to define. It was in this case, I think, due in part to a certain 

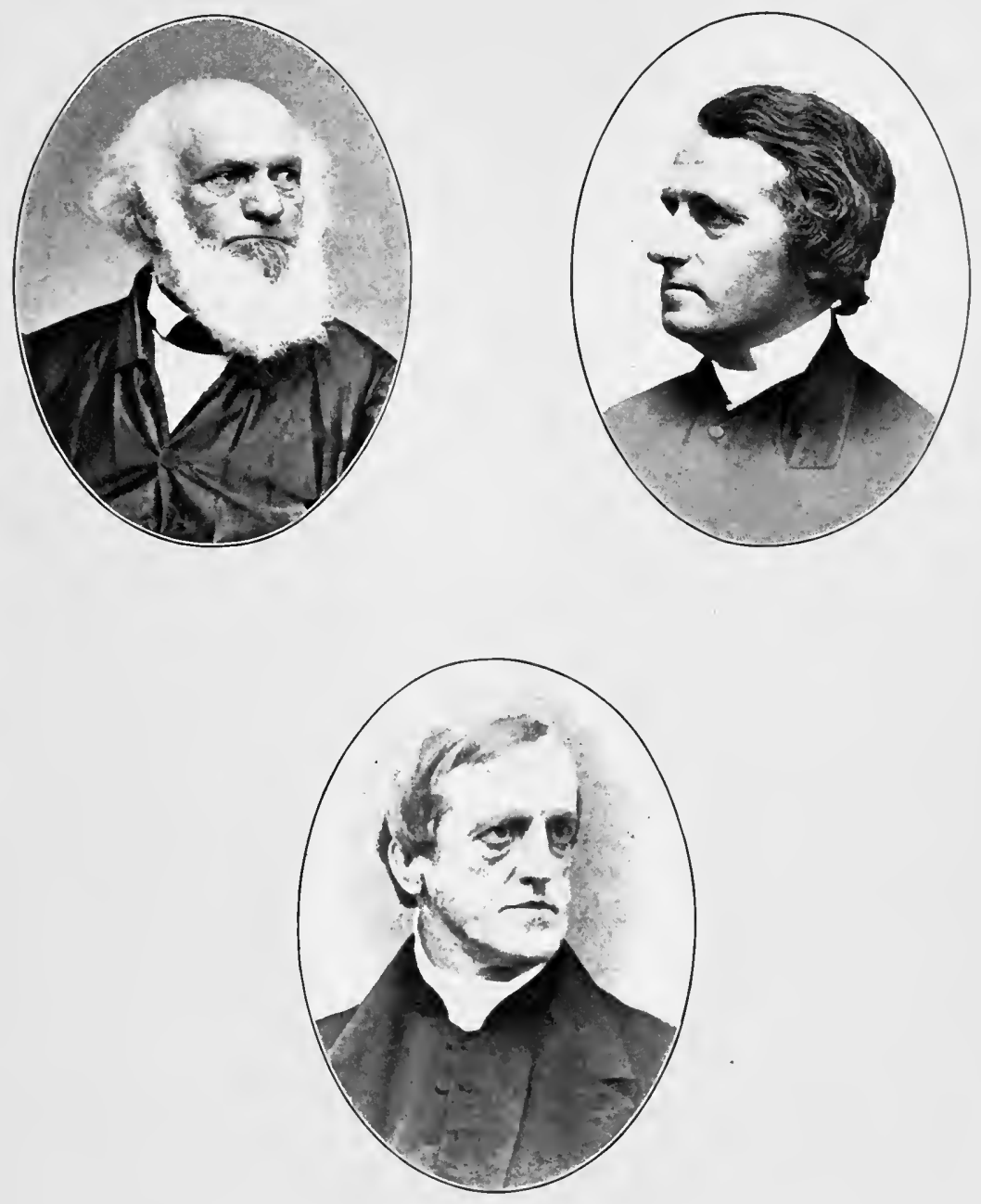

PROFESSORS IN ANDOVER SEMINARY IN THE EARLY SIXTIES Calvin E. Stowe Edwards A. Park Austin Phelps 


$$
\text { • }
$$




\section{THE PROFESSION OF THE MINISTRY}

introspective habit of mind, and was in part temperamental. The lectures of Professor Phelps on "The Theory of Preaching" (since published) made the Andover sermon a distinct product of the pulpit. It stood for clear and accurate thinking, and was always a guarantee of good English. There was an educating as well as stimulating force about it which made it sconducive to long pastorates.

Less distinctively of Andover was Professor Calvin E. Stowe, of the chair of Sacred Literature, sufficiently distinctive, however, in himself, and through his family. Professor Stowe came to Andover just as Mrs. Stowe had brought out "Uncle Tom's Cabin," written while the family was in Brunswick, Maine. The whole family was an invigorating presence on Andover Hill. Its various intellectual gifts had full play under its free and informal habits. Professor Stowe was perhaps the most characteristic member of the group, open, hearty, brusque - a kind of English squire in a professor's chair. He was a wellinformed Biblical student, but an interpreter rather than an exegete. His sturdy common sense pervaded the classroom like a northwest wind. The vagaries of certain German commentators were a constant offense to him and an unfailing source of irritation. Not infrequently when a student would ask (perhaps innocently) if such or such a commentator did not hold an opposite view from that he was expounding, he would burst out: "I know he does; it's a part of his intolerable conceit. I have no patience with him. He is not worth answering." And then he would proceed to "answer," growing more heated as he proceeded till his "answer" brought him to the invariable conclusion - "Gentlemen, no more lecture to-day: voice all gone." 
Other men had then recently entered the Faculty who were to add to its influence and reputation, but these men together with the working traditions of the Seminary made up the Andover of the day. It represented an advanced theology, keen intellectual life, and the spirit of devotion for service at home or abroad. What was lacking, and the lack was serious, was some fresh, more direct, and penetrating approach to the heart of Christianity. The theological advance from old to new school had created an unmistakable feeling of satisfaction. The "New England Theology" was quite too near the finished article. Like every great religious holding of the truth, it was vitalized at times by spiritual quickenings, but the continuous struggle after truth, the tremendous earnestness of search rather than of inquiry, the conflict with doubt, the baffled but determined demand for personal assurance and personal possession, were not conspicuously in evidence. The theological atmosphere was not highly charged with intellectual or moral passion.

The relief from this condition, supplying the very element which was lacking, came to some of us from an unexpected and apparently incidental source. Toward the close of my seminary course, the "Life and Letters of Frederick W. Robertson," of Brighton, by Stopford A. Brooke, were published. Several editions of his sermons had already been issued. Taken together, they revealed a mind which had passed through the stage of doubt, search, and conflict, and was now able to state the intellectual results of personal experience with the lucidity of genius. Robertson's gift was the supreme gift of interpretation. He was able to carry over the consideration of theological subjects from the region of dialectics into the region of interpreta- 
tion. He refused to become the champion of any school or party. Indeed, no school or party was disposed to accept him as a champion. He stood quite alone during his brief life, even among those with whom he would have been naturally affiliated, not through any obstinate independence, but separated from like-minded men by the solitariness and intensity of his intellectual and spiritual experience.

I refer somewhat at length in this connection to Robertson's career in the desire to explain the unique and timely influence which he exerted, and out of a sense of personal gratitude. Robertson died at thirty-seven. What may be termed his career was comprised within the last six years of his life, during his incumbency at Brighton, and his influence was chiefly posthumous, entirely so in this country and largely so in England. His name was not known as a preacher in London, and he received no academic or ecclesiastical recognition. The son of an army officer and of military ancestry, he had set his heart upon the army and had actually received a commission, when at the persuasion of his father, who was a man of strong religious character, he entered Brasenose, Oxford, and in due time took orders in the Church. His early ministry was of the ordinary type except for the display of his rare personal qualities. The stress of theological discussion in England had then fallen upon an exciting but secondary issue known as the Tractarian Controversy, now associated with the defection of Newman from the Anglican Church. The controversy had little interest for Robertson, and no direct influence upon him, but indirectly it produced a great effect upon him. Confused and disheartened by the unrealities, to him, at least, of the current religious thought, he 
determined upon that search after reality which was to lead him ultimately into the assurance of faith. How serious the search became has been told by him in a lecture before the Workingmen's Institute of Brighton, on the introduction of skeptical publications into their library one of the most intimate and courageous addresses ever given on a sensitive public issue. He there lays bare, out of his own experience, that "fearful loneliness of spirit," when the soul "begins to feel the nothingness of many of the traditionary opinions which have been received with implicit confidence, and in that horrible insecurity begins also to doubt whether there be anything to believe at all. It is an awful hour - let him who has passed through it say how awful - when this life has lost its meaning, and seems shrivelled into a span; when the grave appears to be the end of all, human goodness nothing but a name, and the sky above this universe a dead expanse, black with the void from which God himself has disappeared." Of course this experience took him for the time being from the pulpit. He found refuge and spiritual companionship in the solitude of the Tyrol. Otherwise he made his search alone, and as the search and the struggle were his, so the result bore the distinctive mark of his personality. The result was not merely a new acceptance of Christianity; it stood for a new meaning of Christianity. And yet he did not make the mistake of passing by that which was most evident and most easily within reach. His search led him directly to the person of Christ and to that phase of it the most accessible. "It was the Glory of the Son of Man," says his biographer, "which shone roundabout him and lightened his way. In the light of this glory he was able to gain a true measure of the stature of the fullness of Christ." 
The charm and the power of Robertson's conception of Christianity lay in the naturalness of the conception. It made the relation of God to man, and the relation of man to God natural. In Robertson's own words, "Christ came to reveal a name - the Father. He abolished the exclusive 'my' and taught to pray 'Our Father'; He proclaimed God the Father, man the son; man as man, a son of God. He came to redeem the world from that ignorance of the relationship which had left men in heart aliens and unregenerate." "This, then," he continued, "is the Christian revelation - man is God's child and the sin of man consists in perpetually living as if it were false." The significance of Christian baptism in his view was that it declared every one to be a child of God. It revealed and affirmed the natural relation of man to God. Something of the same view was held by Dr. Bushnell in his theory of Christian nurture - "that the child is to grow up a Christian, and never know himself as being otherwise."

,This conception of Christianity, as the power of God working on the basis of human sonship, had never been laid hold of with such clearness of apprehension, or interpreted with so deep and inclusive a meaning as in the utterances of Robertson when he returned to the pulpit. It was the ground of his intense hatred of sin, and of his tender, almost reverent, regard for sinning men and women. And certainly never was the doctrine of Christ enforced with a more passionate devotion to his person.

There was a rare combination of influences tending to give effect to this presentation of Christianity, when once the "Sermons" and the "Life and Letters" of Robertson came to be read so widely on both continents. To those especially who were studying "theology" with a view to 
the Christian ministry, Robertson became in many ways a quickening and guiding force. His intellectual insight, the clarity of his utterances, the unconsciousness of his art as a preacher, his spiritual struggles, his brief and almost tragic career, and his unique personality (he was the most knightly man in the pulpit of his generation) - all conspired to render him a most timely influence in the world of religious thought at the time of my theological studies. There was that about his experience of Christian truth and about his teaching of it, which struck the note of reality. For the impression then made upon my mind of the supreme importance of this quality, in the holding and teaching of the Christian faith, I am profoundly grateful to the influence of the spirit and teachings of Robertson. His fundamental conception of Christianity as revealing the fact of human sonship, every man by nature a son of God, has been the conception which has most influenced me in my work in the pulpit and among men. It has given me a steady working faith in human nature. I have not been afraid of what may have seemed to others to be an overestimation of men. 


\section{CHAPTER V}

\section{TWO PASTORATES}

The Franklin Street (Congregational) Church, Manchester,

New Hampshire, 1867-75

The Madison Square (Presbyterian) Church, New York City, 1875-80

Ir had been my hope that I might begin my ministry in some direct connection with the work of religious reconstruction following upon the war. With this in view, I spent several months in the service of the American Home Missionary Society, in investigating religious conditions in southwestern Missouri and southeastern Kansas. The situation proved to be different from what I had hoped to find. There was little chance for religious coöperation in these parts while the work of political reconstruction was going on. Sectional animosities were in danger of being intensified rather than allayed by the incoming of new religious factors. The churches on the ground were struggling to recover themselves, and looked upon the planting of other churches as an intrusion. The denominational spirit which had been dormant was easily revived. In this circumstance it seemed impracticable to carry out any associated movement, as some of us had intended on leaving the Seminary. Individual openings were gradually found, but no organized effort, of the significance of the pioneer movements of the previous generation in the newer States of the West, proved to be timely, or from the religious point of view desirable. As an instance of the very successful use of an individual opening, I note the career of 
my classmate, James G. Merrill, who became a most influential factor in the religious development of the region.

Previous to undertaking this tour of investigation, I had received and declined a call to the Franklin Street Church of Manchester, New Hampshire. The call having been renewed, after it was found that I did not propose to continue in this service, I returned to accept it. I was ordained to the ministry on January 24, 1867, and at the same time installed as pastor of the Franklin Street Church.

THE FRANKLIN STREET PASTORATE

The city of Manchester belonged to a group of young manufacturing cities in the valley of the Merrimack, which were the precursors of new forms of material development, and of new types of social organization throughout New England. It had grown from a village of less than a thousand in 1836 to a population of over ten thousand in 1846, at which time it was the largest town in New Hampshire, and the first to be incorporated as a city. Twenty years later its population had trebled. But the growth was in no sense loose and unorganized. The underlying organization was the Land and Water Power Company which controlled the water-power at the Amoskeag Falls, and had purchased sufficient adjacent land, not only for the uses of the corporation, but also for the initial uses of the city. Reservations were made for parks and public buildings. Although the development of the city was planned, it was not controlled, as in some more recent instances of cities known as "corporation communities." The manufacturing city of New England was a free city. The original, or in some cases originating, corporation had no exclusive civic rights. Most of these cities came to represent diversified 
industries. The Manchester Locomotive Works were in time as well known as the cotton mills. Each one of these early manufacturing cities has continued to feel the initial impulse, but in every case, so far as I know, the expansion has been according to its own necessities or ambitions.

At this stage in its development, Manchester grew by the natural inflow of population rather than by importation of labor. The native population, still quite large in proportion to the foreign, came in chiefly from the neighboring towns, and from Massachusetts. The foreign population was principally Irish, with an admixture of German and French. The number of men representing the various kinds of business and the professions was relatively large. The situation was inviting to men of initiative. There was the promise of prosperity on secure foundations. The city had gained an established character while yet in the constructive and formative period. The city grew steadily and healthily, and men went about their daily work under stimulating conditions.

The spirit of the city was reflected in the character of the churches and of the ministry. Of the two Congregational churches, the Hanover Street, organized at the very outset, had risen to immediate influence under the labors of the Reverend Cyrus W. Wallace (whose ministry it was to enjoy for forty years), - a man of great moral force made peculiarly effective by his native eloquence. The Franklin Street had become equally influential through a succession of pastorates held by men of varied ability - Henry M. Dexter, afterwards editor of the "Congregationalist"; Henry Steele Clarke, later of the Central Presbyterian Church, Philadelphia; Samuel C. Bartlett, after his pastorate and professorship in Chicago, President of Dart- 
mouth College; and William H. Fenn, my immediate predecessor, a man of brilliant parts in the pulpit and in society, for many years afterwards pastor of the High Street Church, Portland, Maine. The effect of this succession was twofold. Each pastor drew to the church a certain number of like-minded persons, a process which broadened its intellectual life; and the comparatively frequent choice of pastors, especially as they were for the most part young men (three including myself were directly from the Seminary), made the church in time self-reliant and discerning. The educative power of the church over its ministers became quite as marked as that of its ministers over the church. ${ }^{1}$ I found its unconscious but real training more valuable than a graduate course of study. There was an utter absence of criticism, the whole attitude was sympathetic, but I understood at once that much was expected. The stimulus, though applied through attention, quick appreciation, and hearty response, was none the less to be interpreted as a stimulus.

1 In speaking at the Semi-Centennial of the Franklin Street Church - October 9,1894 - I referred to this as a continuous characteristic of the church. "It is one of the peculiar distinctions of this church, as all of its pastors will testify, that the church has educated its ministry as much as its ministry has educated the church. The old proverb - 'Like priest like people' - stands partially reversed in its history. With two notable exceptions - I refer to Dr. Bartlett and to Dr. Spalding - the church has called into its service from first to last untried men, or men who were in the formative stage of their ministry." (At that time the number was eleven.)

I took occasion also at this time to refer to the very happy circumstance of my rece, tion into the home of Dr. and Mrs. Josiah Crosby, where I remained till my marriage two years later. "How shall I tell you of the generous home which was openel to me at my coming, that of Dr. and Mrs. Josiah Crosby? What I would that $I$ might say to them is the assurance of my growing affection and esteem. What I wish particularly to say to you of them is, that not a word was ever said by either one touching any members of this congregation which they might not have heard to their advantage." To which I might have added that in their personal lives, so calm and strong, so full of public spirit, so brave in sorrow, so clear of mind in things temporal and spiritual, I found a daily interpretation of the Christian faith. 
I like to recall the influences which were at work in and through this early pastorate, they were so determinative and so far-reaching in their effect. It was there that $\mathbf{I}$ learned that first and most imperative lesson of the pulpit - to respect one's audience; not to fear it, but to respect it. I doubt if there is any habit from which it is so difficult for a preacher to recover, or one in the end more fatal, than the habit of dealing in unverified knowledge, of substituting the premature appeal for the compelling thought, of underestimating the power of the deeper motives which underlie the spiritual nature. It was of peculiar advantage to me that $I$ began to preach to an audience of severe intellectual demands, as I was endeavoring from the first to train myself to the freedom of direct speech in the pulpit, without the habitual use of manuscript or without reliance upon verbal memory. I knew, of course, that the surrender to spiritual feeling, that the spiritual abandon which the truth in hand may call for, was unsafe and ineffective unless the preacher could assume the steady and reliable support of clear, terse, and truthful speech - speech which would not weaken and disperse his emotional power. But no theory of preaching could have meant as much to me as the aid which $I$ received from the unconscious coöperation of the audience. Whatever of freedom I may have gained in the pulpit or on the platform, I owe to the patient and sympathetic help of those in my first pastorate whose insistence upon the realities of speech was not to be misunderstood.

Among the most encouraging results of the Franklin Street pastorate was an experiment carried out in the constructive study of the Bible. It had seemed to me that the principle of utilizing a church to its full capacity, through 
the careful organization of its benevolence and of its mission work, might be applied with even more advantage to certain phases of its own inner life. I had felt that the receptive habit had been over-developed in the churches, particularly in reference to the interpretation of the Scriptures. "Lessons" and "Lesson Helps" had virtually supplanted the direct and original study of the Bible. To recover this lost privilege of "searching the Scriptures," the church was led to attempt the work of preparing its own courses of study for the use of the Sunday School. As a preliminary step, a course of lectures was given, running for several months, in which I traced in detail the formation of the New Testament. The experiment awakened great interest, and called forth earnest study on the part of those who volunteered for the service. Two courses on Old Testament subjects and two on "The Christ of the Gospels," each occupying a year, were prepared and used. The effect was remarkably quickening. The teachers' meeting, held at the close of an early Sunday evening service, was very largely attended by members of the congregation and not infrequently by strangers, and the discussions were often protracted. The Sunday School doubled its membership, the increase coming chiefly from adults. And as a final result, the spiritual cffect upon the school and the church was most significant. I quote the following reminiscence from a letter of Judge Samuel Upton, then superintendent of the school, to whom we were chiefly indebted for the success of the movement, recalling one of the more impressive spiritual incidents connected with it. The letter was written for the Semi-Centennial of the Church. "Well do I remember," he wrote, "one pleasant Sabbath day in the fall of 1874. A quiet stillness pervaded 
the opening exercises, an earnest thoughtfulness marked the study of the lesson. This was upon the parable of the Great Supper, especially upon the excuses made for not accepting the invitation. In the absence of the teacher, I heard a class, composed of misses, many of them members of the High School. In the discussion of the excuses, one of them remarked that she thought them trivial and poor. It was suggested that the invitation was to each one of them, and the question was asked, How does your excuse compare with those mentioned in the lesson? A moment was given for consideration, and then one said that she feared her excuse was no better. Another said the same; a third replied, 'I make no excuse, I accept the invitation.' It was the first fruit of a golden harvest - the gathering into the church during the year following of more than eighty upon profession of faith - almost all from the Sabbath School."

Perhaps the most interesting feature of the development of the church during this period was its social expansion, or expansion in the direction of democracy. Like many churches of intellectual and social standing in a community it had acquired a reputation for exclusiveness. This reputation entirely belied its spirit. All that was needed to overcome it was some fit method of exercising its hospitality. Fortunately the site and the structure of the church building suggested the method. The church was located on a retired street adjacent to the City Hall and the City Library. It was passed by many operatives on the way to and from their daily work. The women of the church readily coöperated in a plan of making the parlors on the basement floor available to the young women operatives for their winter evenings. The parlors were fitted up for this 
purpose, furnished with reading matter and with games, put under the care of a trained worker, and made in all possible ways attractive for individual improvement and for social entertainment. This experiment in church hospitality was greatly appreciated, and served its purpose admirably till it developed into the Young Women's Christian Association of the city.

The church building itself was a plain structure of the type of the old Mount Vernon Street, Boston, and Kirk Street, Lowell, modeled after Plymouth Church, Brooklyn. The chief characteristic of the auditorium was the space allotted to the galleries. When these were unoccupied, as was the case at this time in the Franklin Street Church, it gave to the whole interior an unsocial appearance. The congregation filled the floor to repletion, but it halted at the gallery stairs. Social values declined with the ascent. At length it was agreed among several families who could afford to make the change, to leave their pews below and colonize the galleries. It was not long before their presence removed the unsocial barrier, and insured more perfectly than by any form of solicitation, a response to the hitherto unaccepted hospitality of the house. The result was not another separate congregation, but the expansion of one homogeneous congregation.

The seven years of pastoral service in the Franklin Street Church were to me years of absorbing and satisfying interest. I had meanwhile no thought of or desire for service elsewhere. I never preached as a candidate in any church, or encouraged the solicitations of church committees, however persistent, to culminate in a formal call. In two or three cases, calls were extended as a more formal way of solicitation. One call came to me during the Franklin 
Street pastorate - from the Pilgrim Church in St. Louis - which in other circumstances would have greatly moved me. It was a call from the general region where $\mathbf{I}$ had hoped to begin my ministry; but as I had not found it advisable to enter it as a home missionary, $I$ felt that it would be inconsistent to make my entrance into it as the pastor of a city church.

The close of my pastorate at Manchester came about naturally, and through the local situation. The growth of the church had given rise to the question of enlargement or of removal. I had advocated on general grounds, as well as for local reasons, the policy of the strong church, strong not only in resources, but in numbers. When I saw, however, that my advocacy was in danger of giving the movement too much of a personal aspect, I decided that it was best to withdraw altogether the personal element, and allow the policy to work itself out in its own time upon its own merits. Three years later the policy was adopted and carried out, insuring the stability and adequate effectiveness of the church. In the meantime, the Madison Square Church of New York made renewed overtures to me leading to a call to the pastorate, which after several conferences, though without previously occupying the pulpit, I accepted, and was installed as pastor of that church on the 12th of May, 1875.

\section{THE MADISON SQUARE PASTORATE}

In looking over such correspondence as has chanced to remain regarding the removal to New York, I found a letter from Dr. Manning, of the Old South Church, Boston, remonstrating in right brotherly fashion against $\mathrm{my}$ leaving New England. There were other letters of the 
same purport, but as there were no determining questions of duty apart from the circumstances attending the call, I decided upon a change of environment. It seemed to me that the traditions of one's religious training should not be allowed to fix the limits of his possible service; rather that as occasion might demand he should come to know, and take a part, in the broader religious life of the country. The denominational change involved in the present instance was of little account. New England Congregationalism had its affiliations with that branch of Presbyterianism of which the Madison Square Church was the chief representative in New York City. The difference in polity was hardly discernible in the practical working of church life. The real change was in the religious atmosphere. The New York of that day was less theological, but more religious than Boston. Mr. William E. Dodge, Jr., who was an intimate friend of Dr. Duryea during his pastorate in New York and Brooklyn, remarked after hearing him in his later pastorate at the Central Church, Boston, "Duryea is a great preacher, but Boston is making him confoundedly metaphysical." Church attendance and church observances were more in evidence in New York. Family religion was held in more scrupulous regard. On the other hand, there was less of what may be termed the "intellectual appropriation" of religion. Individual doubt or questioning was more rare. Religion was conformity, obedience, service. This last characteristic was as genuine as the others and was exemplified in many ways. Every church had its mission, and the general philanthropic work of the churches was carefully organized and generously supported. One of the most touching incidents in my pastoral visitation was my visit to an old gentleman 
of fourscore, upon the occasion of the death of his wife of about the same age. They had been of one mind and purpose in their lives. Probably no one in the city had given or raised more money for the relief of the more acute forms of suffering than my aged friend. After a little he took me into the room where his wife lay. Uncovering her face, he talked of their common life as only the voice of age and love could speak. Suddenly he paused, and took a letter from his pocket - "There," said he, "is my check from Mrs. Stewart for my woman's hospital." Then resuming the conversation as if there had been no interruption there really had been none - he re-covered the face of his dead, and withdrew to take up again his now solitary but still joyous work.

During the decade from 1870-80, the pulpit of New York had begun to assume an unwonted character, through the importation into several of the prominent pulpits of preachers from abroad - Dr. John Hall, from Dublin, to the Fifth Avenue Presbyterian Church; Dr. Llewelyn D. Bevan, from London, to the Brick Church; Dr. William M. Taylor, from Liverpool, to the Broadway Tabernacle; and Dr. William Ormiston, from Canada, to the Collegiate Church on Twenty-ninth Street. Among the well-known preachers native to the city or to New England were Dr. Morgan Dix, of Trinity Church; Dr. Potter (afterwards Bishop), of Grace Church; Dr. Henry W. Bellows, of All Souls (Unitarian) Church, near Union Square; Dr. Howard Crosby on Fourth Avenue, and Dr. William Adams at Madison Square. The unhappy contention between the two great pulpit orators, Henry Ward Beecher and Richard S. Storrs, had greatly weakened the influence of the pulpit in the neighboring city. Union Theological Seminary 
was the intellectual stronghold of the more advanced Presbyterianism of the city, under the direction of Professors Henry B. Smith, Roswell D. Hitchcock, Philip Schaff, George L. Prentiss, and William G. T. Shedd. Not less was the moral strength and executive ability of the Presbyterian churches exemplified in such laymen as William $\mathbf{E}$. Dodge, father and son; George W. Lane and John Taylor Johnston, John Crosby Brown and D. Willis James.

The Madison Square Church, after the usual method of church colonization in New York, was organized out of a downtown church - the Central Presbyterian Church on Broome Street. This was in 1853, and at the close of the following year it was able to occupy its house of worship on Madison Square. The growth was immediate and rapid, due to two causes - the leadership and ministry of Dr. William Adams, and its location. Dr. Adams was a man altogether of New England antecedents, the son of John Adams, the third principal of Phillips Academy, Andover, a graduate of Yale, and of Andover Theological Seminary. His first pastorate was at Brighton, Massachusetts. For seventeen years he had been the pastor of the church on Broome Street, taking with him as the chief asset for the new church the reputation, confidence, and affection which he had there gained. He had beyond almost any minister I have known, the ideal qualifications for the ordinary city pastorate, the pastorate of the family church. He was a man of such personal presence as never to require a gown in the pulpit, of kindling and persuasive speech, sincere and unaffected in manner, a man of the domestic affections, but equally of high public spirit, moving men in public and winning them in private by the power of his personality. It was fit that the Madison Square Church 


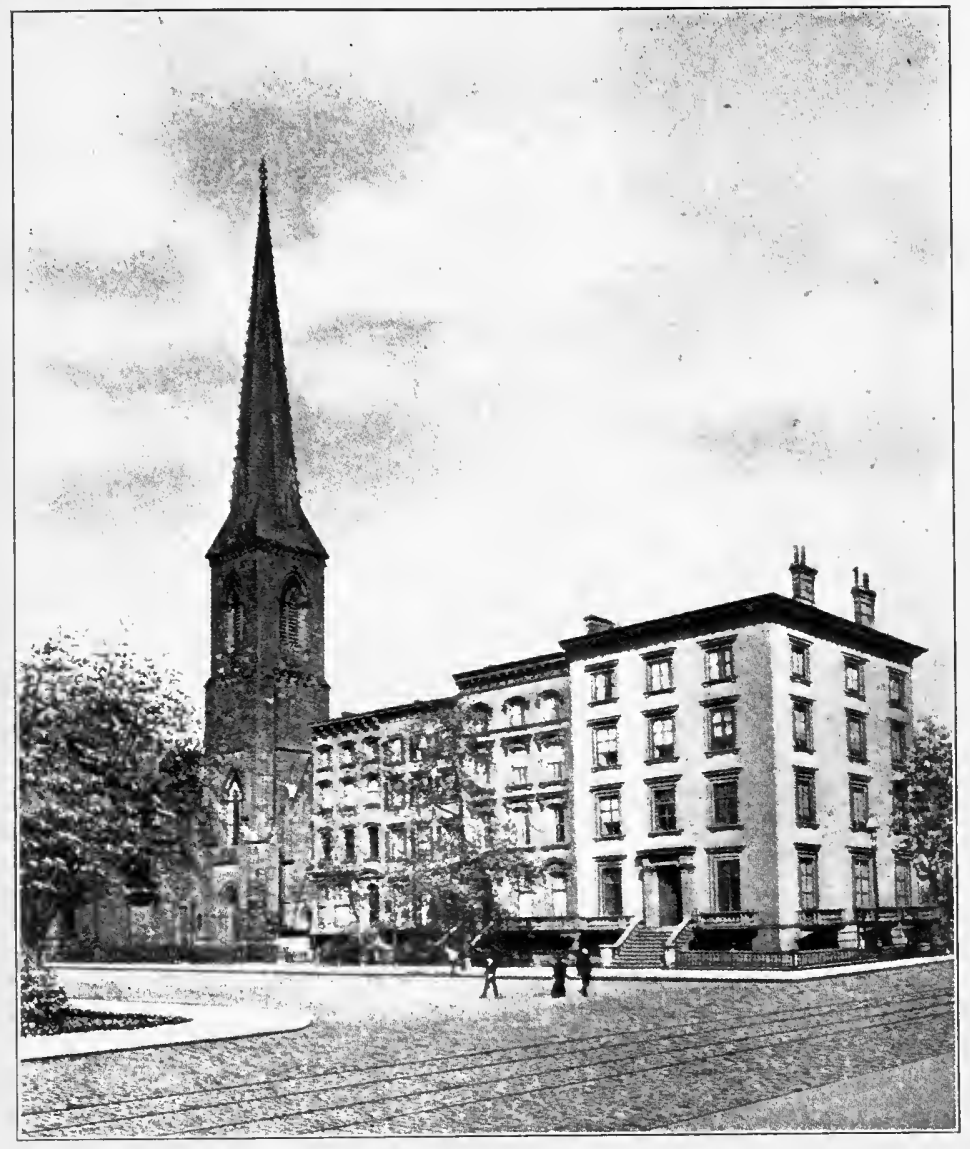

MADISON SQUARE CIIURCII IN THE SEVENTIES 

should have become known with almost equal recognition as Dr. Adams's church. And yet, as I have said, the church owed much to its location. Its site on the east side of Madison Square, where the tower of the Metropolitan Building now stands, was as adequate and as timely for a church as the site directly across the park, where the "Fifth Avenue" held its long supremacy, was for a hotel. Both caught and held for a time in their respective ways the social tide as it swept over Twenty-third Street toward the north. Madison Square became at once one of the accessible religious centers, which was to be repeated later on upper Fifth Avenue and later still on the west side of the Park. The constituency of the church ran from Gramercy Park and West Twentieth Street up Fifth and Madison Avenues, and along the adjoining streets as far as Fortysecond Street, and gradually up to Central Park. For this choice of its location, as for the subsequent management of its business affairs, the church was indebted to George W. Lane, for many years Comptroller of the city, and from the first a trustee of the church, a man as well known and trusted for his sagacity as for his integrity.

I recall with much distinctness and even vividness my first Sunday in the Madison Square pulpit. I had never seen the congregation and few had seen me. It was a day of first impressions for minister and people. As I faced the audience which thronged the church, I found myself steadied and quickened by the sensitive and apparently eager response to my message. There were faces in that unknown congregation which made an immediate and lasting impress upon my mind. I preached from the text, "God is not the God of the dead, but of the living," the conception of God as more vitally concerned with 
human life as it grew more absorbing and controlling, with human interests as they multiplied and increased, with our individual lives as they became capable of greater responsibilities, or became weakened and demoralized under the strain of our environment. It was a message to the modern man asking where and how he might find God - not at first and chiefly in the past, but in the present, not among the dead, but among the living. Whatever other effects the message may have produced, I was made conscious of this verdict, which was to me the most to be desired, "You have made your connection with us; we understand you; we are no more strangers."

As I became more familiar with the congregation, I found that there were two somewhat distinct but not diverse types of mind in their response to truth. There were those who quickly kindled under the reception of it, and gave it free play in their own thinking, more affected by the quality of inspiration it might possess than by any logical conclusion to be drawn from it. Such preëminently were Professor Roswell D. Hitchcock, Judge John K. Porter, and Mr. Charles Collins, formerly of Hartford, Connecticut, a genuine disciple of Dr. Bushnell. There were others who absorbed the truth according to its immediate adaptation to their spiritual needs. The general characteristic of the congregation was its mental and spiritual accessibility. Individuals and families came to church imbued with the spirit of worship, and in a mood to be appreciative of such further help as might be gained from the service. The degree of this desire for help was unexpected. It was especially noticeable among men in public life and in the more exacting forms of business. Judge Porter once remarked to me that, "Judged by the 
test of the responsibilities public and private of those who attended the church, there was no pulpit in the city which had more direct access to the sources of public welfare." During my pastorate, two mayors of the city were members of the congregation. My personal intimacy with Mayor Wickham gave me unusual opportunity for the knowledge of certain phases of the inner as well as public life of New York. It was the consciousness of the fact to which Judge Porter referred that led me to give to my preaching so far as possible the tone of moral invigoration and of spiritual quickening. I recognized the fact, of course, and acted at fit times upon it, that the discussion of public questions had a legitimate place in the pulpit, but the essential thing as it seemed to me was to increase the moral sensitiveness and to stimulate the moral purpose, of those who had most to do with the intricacies and liabilities of affairs. And it was at this point that I found, as I have said, a ready response.

The same characteristic of accessibility obtained in all the relations to the people. It made pastoral duty a pleasure and in many cases a satisfaction. The homes of the church stood open to one professionally on the basis of personal friendship. And one could count upon an equal accessibility in discussing measures in the interest of the church, or in the solicitation of funds. Quickness of decision and promptness in action greatly facilitated religious work. An illustration of a certain intimacy in the religious life of the church was the midweek meeting in the vestry, known in the churches of the city as the "lectureroom." The name rightly described the nature of the midweek meeting. It was not altogether or chiefly a prayer meeting. The chief feature was a pastoral "lecture" or 
informal talk on subjects of deeper religious import. The meeting was largely, at times very largely, attended and allowed the most direct and intimate approach. I was often surprised to note the attendance of those from the congregation who were not members of the church, to whom the service seemed to give spiritual satisfaction and strength.

Naturally the pastoral relations open the way into friendships, and at times into intimacies born out of the deeper experiences of life; but outside these intimacies and friendships it also opens the way into personal associations of a more or less intimate character with men of recognized public value. Every influential church in New York has in its congregation men of distinction. The Madison Square congregation held not a few such men, some of whom I came to know in circumstances that brought out very clearly the qualities which gave them their place in the public thought. I may fitly refer in this connection, for the impression made upon my own mind by the extraordinary display of qualities, not unusual but perhaps for that reason more impressive when exercised in some superlative way, to two men of the congregation, Cyrus W. Field and Samuel J. Tilden.

Mr. Field represented in this superlative way the type of man "who brings things to pass." The type itself was not unfamiliar in the period of material development following the Civil War, but no such example of it appeared then, or has appeared since, as in the man who laid the Atlantic cable. The original conception did not belong to Mr. Field, but he alone grasped the idea with an unshakable purpose, and brought the bold adventure to reality. It was ten years from the organization of the Atlantic 
Telegraph Company to the completion of the enterprise. Eight years of silence intervened between the broken message which passed over the first cable, and the final accomplishment of unbroken communication between the continents - years of persistent effort, but of equally persistent failure, including bankruptcy, but years closing in triumphant success. This mastery of failure was Mr. Field's distinction. Adjectives commonly applied to one capable of this kind of success - persistent, indefatigable, indomitable - do not define his capacity, or explain the great event in his career. Back of all the energies of his nature was the faith that constantly visualized the end in view, and a will that never for a moment lost control of the means for its attainment.

When I first knew Mr. Tilden, he was passing through the ordeal of surrendering the Presidency which had seemed to be within his grasp. Out of one hundred and eighty-five electoral votes necessary to a choice in the election of 1876, he held one hundred and eighty-four in undisputed right. Of the votes claimed by his opponents, nineteen were in dispute, which, if entirely allowed, would complete the number necessary for a choice. Eighteen of these were from the States of Louisiana, South Carolina, and Florida, localities where the political atmosphere was charged with fraud, and one was from Oregon. To a mind like that of Mr. Tilden, trained to respect for constitutional methods, and exercised in the detection of fraud through his exposure of Tammany, the resort to a compromise political commission to pass upon the votes in dispute seemed a wide departure from the Constitution, while the finding of the commission seemed to him utterly at variance with the legal evidence. 
Nevertheless Mr. Tilden determined to abide by the decision of the commission, and forbade his friends and his party to resist. His conduct was a most remarkable exhibition of self-control, perhaps the most remarkable in the political history of the nation, undemonstrative, but wonderfully inpressive. As I saw what it meant to him and realized its meaning to the country in the crisis through which it was passing, I understood the recorded wisdom of the old-time moralist, "Better is he that ruleth his spirit than he that taketh a city." When I went back some six years after leaving New York to conduct the services at the funeral of Mr. Tilden at his country home at Graystone-on-the-Hudson, I was impressed with the sincerity of the homage paid to him by the vast company of public men there assembled, from President Cleveland and his immediate associates to the eminent citizens of the city and of the State.

Of the men with whom I came into professional as well as personal relation, no one awakened so deep an affection or exerted so great an influence over me as Roswell D. Hitchcock, to whom I have already referred as a member of the congregation. Dr. Hitchcock was a man of wide and genuine learning, but still more remarkable for his mental and spiritual insight. He saw religious truth in clear perspective and in just proportion. As a church historian he knew and honored the historic Church, but he lived in the full freedom of the spirit. His independence could rise, if there was occasion, into courage. He was broadly and fearlessly progressive. Personally he was capable of sharing the riches of his mind and heart. His friendship had the reality and the charm of intimacy. Though several years my senior he never allowed the inter- 
vening years or the wisdom for which these stood, to create the slightest impression of conscious superiority. He was to me a most lovable man, not in spite of his great intellectual gifts, but because of them. I felt whenever I talked with him that I had access to the whole man. It was to me of great significance in the following years that this intimacy of personal friendship was in no sense dependent on frequent contact. The letters which came to me at Andover until his death bore the marks of the same rare and quickening friendship.

Professional intimacies were furthered by a semi-social and religious club known as Chi Alpha, composed of leading ministers, professors, and journalists from affiliated churches. It met every Saturday evening and preserved its social character by meeting in the homes of its members.

It frequently entertained distinguished visitors from abroad. At that period - among the seventies - the reception of churchmen, like Dean Stanley and Canon Farrar, Dr. Parker, of the City Temple, London, Dr. Dale, of Birmingham, and various Scotch leaders, was more frequent and more natural than that of literary men. The visit of Dickens, and Thackeray, and even of Matthew Arnold, had somewhat the aspect of a commercial adventure. The visits of these and like guests were seldom disconnected from lecturing tours. Chi Alpha was one of the oldest of the professional clubs of the city, having been founded in 1828 .

The following letter, written to the Secretary on the occasion of the eighty-sixth anniversary of the Club, gives a glimpse of the ordinary meetings at the time of my active membership: 


\section{Dear Dr. Webster:}

In response to your invitation, I send you greetings from the Chi Alpha of thirty-five to forty years ago. Possibly some of the original members were living at that time, but I have no remembrance of any known as such. One of the early habits of the society, which I see by your present order of exercises has been discontinued, was then in force - supper was served then as now at six o'clock, but it was put between the social hour and the hour or evening of discussion. I suppose that this was a survival of the state of mind which gave us in its time the "New York Observer" in two well-separated compartments. The social hour was the hour of the wits and the story-tellers. Dr. Irenaeus Prime was by far the most delightful story-teller, though perhaps Dr. Rogers, of the Reformed Dutch Church on Twenty-first Street, was the sharper wit. I recall the beginning of one of Dr. Prime's stories, which promised to be one of his best, but which never came to a conclusion. Dr. Prime had reached the point where he had introduced the man's motherin-law, when, yielding to the temptation to play with his story, he remarked by way of parenthesis - "It was his mother-inlaw by marriage." “Oh,” said Dr. Rogers, "a new kind.” The story, as I have said, was never finished. Chi Alpha was abundantly satisfied with the discovery of a new way of establishing this domestic relationship.

The most serious discussion in Chi Alpha which I remember started from an incidental statement by Professor Shedd "God must be just, He may be merciful." The statement instantly aroused much feeling, which was intensified by a subsequent remark of Dr. Chambers, contrasting the depth of the mind of St. Paul with that of the Apostle John. Any one who may have known Dr. Prentiss and his passionate feeling toward the Apostle John can understand how such a comparison would strike his sensitive and chivalrous nature. I think that I never saw Chi Alpha thrown into the like intellectual commotion. The discussion thus started ran through three or four consecutive meetings. I am quite sure that my old neighbor and friend, Dr. 
Vincent, will recall the discussion, as we commented on it each evening on our way home. As I mention some of those who carried on the discussion you will have little difficulty, even at this time, in arranging them according to their theological sympathies - Dr. William M. Paxton, Dr. Howard Crosby, Professors Schaff and Hitcheock, Dr. Adams, Dr. Hall, Dr. William M. Taylor, Dr. George B. Cheever, and Dr. Cuyler. It goes without saying that the five-minute limit in debate was not then in vogue. The discussion was closed with a paper of remarkable lucidity, by Dr. Prentiss, on the question, "What is fundamental in the nature of God?" Some years afterwards I tried to get the paper for publication in the "Andover Review," but Dr. Prentiss felt that it was too vitally related to the discussion to warrant its publication, so far removed from its original motive and environment.

I beg you to tender my affectionate greetings to the present members of Chi Alpha, many of whom I knew in those earlier days of our fellowship, and others of whom I know in ways of personal friendship.

I am

Most cordially and fraternally yours

William Jewett TUCKer

To the Rev. George S. Webster, D.D.

Secretary of Chi Alpha

Notwithstanding the wide range of personal associations incident to a New York pastorate, and the inspiring opportunity which it offers through the pulpit, it has its sharp limitations. These limitations are largely the result of the physical conditions which determine the social life of the city. The configuration of the city virtually classifies its population socially. It divides the Protestant population between church and chapel. A certain segregation is enforced through residence. Class and neighborhood are synonymous terms in defining the church relations of a family. The distinction goes deeper. It classifies the moral 
and spiritual experiences of those living under these different conditions. The burdens, the temptations, and many of the sorrows of the poor are not those of the rich. This exclusion of poverty with its attendant evils from homes in the distinctively church localities creates a restricted field of pastoral service, and puts the special work of what is known as "social service" at a second remove from the pastorate. I am well aware, in saying this, of the liability of a "break" in the environment which may cause a sudden inflow of the turbid stream of the outer life into the more protected regions. It was just such a break in the environment of the Madison Square Church, which Dr. Parkhurst records in "Our Fight with Tammany" (pp. 4, 5), that led him to assume the presidency of the Society for the Prevention of Crime and to carry on his masterly campaign against the organized and officially supported vice of the city. And yet how exceptional and almost casual this splendid service appears from his reference to the pastoral incident which gave rise to it. "Somewhat prior to my first connection with the Society, I had become knowing to a condition of things throughout the city of which during all the years of my residence in town up to that date I lad been ignorant, and of which, except for a special cause, I should probably have continued ignorant."

A further limitation upon the continuous power of the average pastorate lies in the impermanency of the local church life of the city. This limitation is due to the same general cause as the social segregation to which $I$ have referred. Owing to the rapid movement of the church population within the narrow limits fixed by the configuration of the city, a church can hardly expect really to command 
a given locality for more than a generation; that is, a generation represents the ordinary allowance of time between the taking of a favorable location at the flood tide, and the ebb tide which leaves the church to struggle with the decline in numbers and finally to succumb to it. The Madison Square Church occupied Madison Square in 1854. In 1906 it had become necessary to take into serious consideration the question of removal. A bold attempt was made to retain its site on the Square by taking advantage of a favorable offer of purchase by the Metropolitan Life Insurance Company, which had crowded the church to a corner in the enclosure of its own building, and by building a unique and most attractive church edifice on the opposite corner of Twenty-fourth Street. ${ }^{1}$ The attempt, however, has not enabled the church to hold the site. As I am now writing (1918) a plan is under way for effecting a consolidation of the Presbyterian churches in proximity to one another below Thirty-fourth Street, - the Old First Church at Fifth Avenue and Eleventh Street, the University Place Church, and the Madison Square Church. Owing to the effect of the recent act for "zoning" the city, a new permanency has been given to the residential region around Washington Square and lower Fifth Avenue, as against the region about Madison Square. Should the proposed plan be carried out, as now seems probable, the new Madison Square Church will be sold, and the church itself will survive only as a component part of an impressive consolidation, especially of church property and endowments $-\mathrm{a}$ fate on the whole insuring more permanency than usually befalls a New York church in an

1 The original church was by Upjohn, of Gothic design; the new church, by McKim, Mead \& White, the main features of which are a "bold portico and front and a dome." 
attempt at continuous separate existence. (Since the above was written this consolidation has actually taken place and the sale of the Madison Square Church edifice has been effected.) The identity of the local church in the city has thus far been best preserved under the Episcopal system of supervision, or under the collegiate system controlling certain of the Dutch Reformed churches supported by original land grants. Presbyterianism has hardly proved equal to this perpetuation of the life of the local church. It was a favorite theory of Mr. George W. Lane, of the Madison Square Church, that a strong church should select, in advance of any sign of decline, a location to which it might in due time remove, while yet in its strength able also to maintain by endowment and annual allowance the position from which the main church had advanced. A line of church holdings would thus be established, following the succession prescribed by the peculiar configuration of the city.

In the spring of 1879 , in the fifth year of my pastorate, $I$ received an invitation to the chair of Homiletics in Andover Theological Seminary, the invitation having in view the further object of my taking part in the reconstruction of the Seminary then impending. Three years before I had been asked by Dr. Edmund R. Peaslee, of New York, and Governor Cheney, of New Hampshire, representing the Trustees of Dartmouth College, if I would consider an invitation to the presidency of the college. As I had then been so little time in the pastorate of the church, and as the educational work proposed was at a second remove at least from the specific work of the ministry, I declined the proposal, little foreseeing, however, that fifteen years later I should be brought to this 
position by way of Andover. The invitation to the chair at Andover raised at once, and in its broad aspects, the question of the relative significance under the conditions then existing of the pastoral and the educational branches of service in the ministry. It was to me a very serious question, becoming more serious the more I considered it. I had become directly interested in the aims and problems of young men studying for the ministry, through the attendance of many of the students of Union Theological Seminary at the Madison Square Church. But the large, and as it proved to be the determining, factor in the ultimate decision was my conviction that the more important issues which were to affect the ministry and the Church lay within the sphere of education. In the midst of the experiences attending the discharge of pastoral duties, and more particularly in the midst of the daily studies in preparation for the pulpit, questions would arise out of the intellectual and moral changes taking place in the new world of thought and action for which little time could be found for any satisfying answer. It was evident that a process of reconstruction was going on in which, if one was to take part at all, he must have a place nearer the sources. And the necessity for the closer range of thought was equally apparent, whether one considered the critical or the social questions which were fast becoming the problems of modern Christianity. It was under this conviction of the need of a nearer approach to the distinctive religious issues of the time, and in the hope of accomplishing the larger service for the ministry through those who were entering, or who might be led to enter it, that I decided to exchange the pastorate for the professorship to which I was called. In the view which I took 
of the religious situation the step from the church to the Seminary was a forward step - my response to the demand of religious progress.

The changes necessitated by this decision could not be carried out without much occasion for sincere regret, and at certain points without a very definite sense of loss. There was the surrender of the pastorate with its incentives to spiritual activities; there was the separation from the church, in itself a painful process, intensified by the reluctance of the church to accept my resignation; ${ }^{1}$ and

1 Among the notices of the press in regard to the resignation from the Madison Square Church, the following report of the meeting attending the acceptance of the resignation is taken from the New York Tribune under date of October 9, 1879 :

"At a meeting of the members of the Madison Square Presbyterian Church last evening, the resignation of their pastor, the Reverend W. J. Tucker, D.D., who has received a call to the Bartlett Professorship of Preaching at Andover Theological Seminary, was tendered and accepted. There was a large number present. Dr. Tucker, in offering his resignation, remarked that it was already well known to them all that he had had under very serious thought during the summer the question of a change from the pastorate to work for the ministry. He said that the ministry in its claims ought to have a wider hearing among young men. The great increase in the means of moral influence demanded this. 'We seem about to enter, in religious life and thought,' he added, 'upon a period of great constructive energy. I believe that we have before us a season, not of contention or of apology, but of growth and construction. . . However reluctant, therefore, one might otherwise be to listen to this call, he cannot deny the claims of its timeliness. And it is only for such reasons as these, which but partly express my own convictions, that I can bring myself to ask you for your consent to my entering upon this work, and to request, as I do now, that you will accept my resignation in the pastorate of this church.'

"Dr. Tucker closed his address with some words of deep feeling upon the cordial relations which had existed between his church and himself. George W. Lane was then made chairman of the meeting and Charles H. Woodbury secretary. Resolutions were adopted expressing deep regret at Dr. Tucker's leaving the pastoratc, and speaking of his work and his personal qualities in the highest terms.

"Remarks were then made by the Reverend William Adams, D.D., first pastor of the church, the Reverend Roswell D. Hitchcock, D.D., the Honorable William E. Dodge, and Professor Theodore W. Dwight.

"Dr. Adams said that he concurred most heartily in the resolutions. He could sympathize with Dr. Tucker in his request, for he had once taken a similar step. His personal relations with Dr. Tucker had been peculiarly pleasant. 
there was the sundering of many ties of personal and family friendships; to which I may properly add my regret in leaving New York. There was a sincerity in its social life which could be felt. Deeper by far than its power to fascinate was its power to awaken affection. I had never been unmindful of my attachment to New York since I first knew it, but $I$ was hardly prepared for the feeling awakened in me by a personal incident which occurred some years ago in passing through the city. I had but an hour between trains, but as I passed from one station to another I took my way by the church. It was partly torn down to make place for the tower of the Metropolitan Building. This I had anticipated. But on going up Park Avenue to No. 57, my old home, I found that this also, with two adjacent houses, was in ruins through a caving-in of the street incident to the excavation for a tunnel. Thus dispossessed of my personal holdings in the city, though held only by the title of sentiment, there came upon me a sudden but veritable attack of homesickness, that unmistakable mark of local affection.

"Dr. Hitchcock said that he did not believe that there was a person in the congregation who would not say farewell in great bitterness of personal bereavement and sense of loss. He had advised Dr. Tucker to go, because he thought he would serve his generation more in giving to the world thirty or forty Christian ministers each year than by remaining in the most successful pulpit.

"Mr. Dodge said that he felt that he had lost the presence of a personal friend which could not be replaced. He hoped Dr. Tucker's influence would long remain in the church, but the bereavement at this parting was very great.

"Judge Theodore Dwight remarked that the announcement of Dr. Tucker's resignation came upon him like a thunderclap. He could say with all the warmth possible that he sincerely deplored the loss which the church sustained." 


\section{CHAPTER VI}

\section{THE PROGRESSIVE MOVEMENT IN THEOLOGY}

I IAVE said that one of the chief motives for leaving the pastorate to enter upon the educational work of the ministry was the desire to study more closely into some of the questions which were becoming the problems of modern Christianity. Of course the large and inclusive question was that of the effect of the impact of the modern world upon historic Christianity. Would it detach Christianity from its own past? The answer to this question had already been made decisively in the negative by both branches of the Christian Church, but their answers differed. Although the Roman Catholic Church had not then pronounced officially upon those tendencies in modern thought which were afterwards to be anathematized under the term "modernism," its attitude of resistance was unmistakable. The attitude of the Protestant churches varied from that of suspicion, or open resistance, to that of investigation, and in some cases of immediate hospitality. The Protestant mind which was most distinctively Protestant was from the first sympathetic with modern thought, and it proved to be the controlling element in the various churches. It was able to withstand if not always to arrest reactionary tendencies. It was also able to influence the modernizing process to such a degree that it did not become revolutionary or merely divisive. It gave rise to no new sects or denominations. It was carried on in all the existing denominations with more or less sharpness of controversy, but nowhere to the breaking point. 
The term which best expressed the character of this modernizing process as it went on in the churches was the term "progressive." It was, in fact, actually in use as a theological term long before it found so conspicuous a place in politics. In 1885, a series of editorial articles appeared in the "Andover Review," which were published the following year in a book under the title of "Progressive Orthodoxy." The part of the title which seemed to the authors of the book to call for explanation was the term "orthodoxy." They put this term forward in protest or challenge against the exclusive claim to progress in behalf of heresy or schism. They said in the introduction: "We are not insensible to the reality and worth of character in the sphere of thought. . . . The word 'orthodox' designates theological character. . . . There is a collective and a continuous Christian consciousness. Our recognition of this relation of the new to the old is expressed in our motto, "Progressive Orthodoxy.",

The progressive movement covered three distinct though related forms of investigation and research - the technically theological, having to do with the method of the Divine working in and through nature; the critical, employed upon the Scriptures and the early Christian literature; the humanistic, concerned with the problems of human environment and human destiny. It was this last subject of investigation and inquiry upon which my own personal and professional interest centered. However, I trace briefly the course followed in each section of the progressive movement, though in so doing I anticipate somewhat the results gained. It will thus become evident that the claim in its behalf at the first was justified - that the movement was not revolutionary but progressive. 
The first effect of the progressive departure in the field of strictly theological inquiry was to bring about a change in the prevailing conception of God. It changed the emphasis from the thought of His transcendence to that of His immanence. The conception of God must be affected by the advance in our understanding of nature. As an English churchman of the evolutionary school has recently said - "We found that when 'all creation widened on man's view' our souls widened and deepened in response; Nature was a vaster home for man, but man was more at home in it not less but more."' In this sense true scientific progress is always reflected in theological progress. The scientific advance from Newton to Darwin presupposed a corresponding theological advance. Theology could not accept and appropriate, as in the astronomical discourses of Dr. Chalmers, the science of astronomy, and ignore or dispute the new science of biology. If the one science seemed to make God greater in the sphere of His working, it was reasonable to expect that the other science would bring Him nearer in His work, and into more intimate relations with the physical conditions of human life. If the one science proclaimed the transcendence of God, the other, it might be assumed with equal certainty when once it had wrought out its sure conclusions, would reveal God as immanent, a pervasive presence in the universe, acting through agencies and under laws beneficent in their purpose.

I think that biological research has already passed the stage of emphasis upon the immoral or unmoral "struggle for existence," and has begun to show that the evolutionary process as applied to the lower forms of life has an

1 The Spectator, January 19, 1918, p. 56. 


\section{THE PROGRESSIVE MOVEMENT}

ethical significance in the fact that its cardinal principle is not destructive but constructive, working through the method of social coöperation. "Altruism," says Professor Vernon Kellogg, of Leland Stanford, reviewing a discussion with a German biologist at German Headquarters, ${ }^{1}$ " or mutual aid, as the biologists prefer to call it, to escape the implication of assuming too much consciousness in it, is just as truly a fundamental biologic factor of evolution as is the cruel, strictly self-regarding, exterminating kind of struggle for existence with which the Neo-Darwinists try to fill our eyes and ears, to the exclusion of the recognition of all other factors." Still more explicit is the contention of Dr. William Patten, of the chair of Zoölogy, Dartmouth, in a monograph on "Coöperation as a Factor in Evolution": ${ }^{2}$

When we realize that evolution is the summation of power through coöperation, that what we call "evil" is that which prevents or destroys coöperation, and "good" is that which perpetuates and improves coöperation; when we realize that the "struggle for existence" is a struggle to find better ways and means of coöperation, and the "fittest" is the one that coöperates best - we shall then realize that science and religion and government stand on common ground and have a common purpose. Until this basic truth is recognized there can be no common goal for intellectual endeavor; no common rules for individual and social conduct; no common standard of what is right and what is wrong; and no common knowledge of that which creates and preserves and that which destroys.... The extent to which coöperation is attained depends on the extent to which "righteousness" is attained; for coöperation cannot take place except the right things are brought into a definite time and space rela-

1 Atlantic Monthly, 1917.

${ }^{2}$ Reprinted from the Proceedings of the American Philosophical Society, vol. Lv, 1916. 
tion to one another. The chief service of coöperative action, therefore, consists in the conveyance of the right kinds of power to the right times and places for further coöperative action.

I think it may be said that to the degree in which scientists and theologians have entered upon constructive work in their respective fields, there has been a marked decrease in agnosticism. Not only has a different temper of mind been created, but results which can be mutually recognized have been secured. The so-called conflict of science and religion is a conflict among the uncertainties created by new conditions, which relaxes if it does not disappear, as the things in dispute emerge into the light of clear definition.

The most sensitive feature of the progressive movement, viewed in its effect upon the religious mind, was the application of the principles of historical criticism to the Bible. Here lay the severest test of its spiritual value. There were definite reasons for this sensitiveness regarding the treatment of the Scriptures. The Bible was throughout the Protestant churches the recognized source of authority, not only so recognized but cherished with affection and pride. There was no outward reason for revolt against its authority as there was against that of the Church, for the authority was self-imposed. And the danger from the revolt of reason was well-nigh removed by the allowance of perfect freedom of private interpretation. The one point of common insistence was its infallibility, which in the popular understanding and acceptance meant the equal authority of the Bible in all its parts from cover to cover.

Furthermore, the Bible had acquired a distinct and peculiar sacredness from its history. It was the book of the martyrs and heroes of the protesting faiths. Men had 


\section{THE PROGRESSIVE MOVEMENT}

suffered and died that it might be free, unbound, emancipated from all ecclesiastical control. It had thus gained a sanctity from its associations almost equal to that inherent in its words. And to this historic sanctity was added the sentiment attaching to its use from generation to generation at the family altar, and in the closet of devotion. For all devotional uses Bacon has said, "those doctrines (are) best and sweetest which flow from a gentle crush of the Scriptures," not from the too severe pressure of analysis.

But the Bible has its place in a world of facts, and in this world it can hold its place only by conforming to the established rules of evidence. It was difficult for many minds to accept so simple but so sweeping a conclusion. It was hard for them to acknowledge that faith, like poetry according to Robert Frost, "must lean hard on facts, so hard at times, that they hurt." Without doubt faith under the pressure of modern criticism was forced to lean hard upon facts, so hard that they did hurt. It would be as unintelligent as it would be unfeeling to overlook or make light of the pain which the critical handling of the Scriptures brought to many devout and intelligent believers. But as the results of Biblical criticism have become evident, the gain to faith has also become evident. It is with no little spiritual satisfaction that we now see that Protestantism has in hand a Bible which it can hold in consistency with its own well-defined principles. A Bible exempted from the tests of historical criticism would not have been a Protestant Bible. Few will now deny the inconsistency of affirming the right of private judgment in respect to the interpretation of the Scriptures, while at the same time forbidding the exercise 
of this right in the investigation of their origin and historical order. From the Protestant point of view, it must be as necessary to ask what the Bible is and how it came to be, as to ask what it means. It is also beginning to be understood that we are indebted to the historical criticism of the Bible for a clearer perspective of revealed truth. The progressive nature of revelation has been determined and established by the knowledge of the periods of progress, and of the persons and instrumentalities made use of for the disclosure and outworking of the Divine plan. And a further gain is beginning to be felt, even more clearly than it can be seen, in the growing sense of the unity of the Church. So long as the Protestant mind was in bondage to the literalism of the Scriptures, it was fruitful in divisions and subdivisions of the Church. Protestantism had become in too large a degree the religion of the sects. It lacked that freedom and confidence and power which can come only from the sense of the wholeness of Christianity. Historical criticism did more than any other one thing to relegate the separating tenets of the sects to their proper place. The new conception of the Bible has already given a new conception of Christianity, larger, simpler, and more unifying.

The distinctive characteristic of the progressive movement, though in some respects the least capable of definition, was its humanistic impulse. It carried religion, and even theology, farther out into human relations. It took account of the individual in his human environment. It viewed him more definitely as a social being, a part of a vast but closely fitting social organization. It followed him into those classifications into which modern society had divided itself, chiefly as the result of the new economic 


\section{THE PROGRESSIVE MOVEMENT}

conditions. It refused to obey the mandate of the old political economy, and leave the individual to the fortune of the market-place. It assumed the right to know the reason, for example, of the contentions of capital and labor, and the right no less to take part in the whole economic conflict according to its social significance. The movement early acquired the name of social Christianity.

There was in this projection of religion into the new relations and conditions of modern society, no such disturbance of religious faith as was caused by the application of the critical method to the Bible. But it disturbed the conventional religious sense, and broke in upon many religious conventions. The charge was brought against the movement that it secularized religion. The religion of the previous generation had become largely introspective. The proof of its reality rested in certain experiences. It sent the religious man to his closet. It also sent him out into the "byways and hedges"; it was a religion of charity as well as of experience. But it did not send him into the shop or the factory. It was not a type of religion fitted to understand or to meet the problems involved in the rise of industrialism. It virtually accepted the prohibition written over the doors of the new workshops - "No admittance." It was bold to the highest degree of sacrificial courage in its missionary zeal, but it shrank from contact with the growing material power of the modern world. It saw the religious peril of materialism, but not the religious opportunity for the humanizing of material forces.

The progressive movement also ran counter at this point to the prevailing religious philosophy. The philosophy of Protestantism was altogether individualistic, while that of Catholicism, though taking far more account of the 
individual in his religious or non-religious environment, was by no means socialistic in the modern sense of the term. The long reign of individualism had produced its own habit of mind, dominant alike in politics and religion. This habit of mind was naturally unsympathetic with the social tendencies of modern thought. It could not understand the significance, hardly the meaning, of a rapidly developing class consciousness under the advance of industrialism. Least of all was it able to appreciate the religious effect of those associations which were gradually alienating large numbers within the industrial communities from the services of the Church, and even from its influence.

In carrying out its humanistic impulse, the progressive movement did not stop short of the attempt to humanize the current theology. The current theology as expressed in the creeds was not sensitive to the human demands made upon it. The creeds had been for the most part prepared to meet errors existing at the time, and then considered most dangerous. They were unnecessarily explicit at points which had lost their first importance. In certain other instances conclusions and inferences, logical but now unreal, had been allowed to stand. This was especially true of the doctrine pertaining to human destiny. It is hardly too much to say that the current Christian theology had reached an impasse at this point. It affirmed the necessity of personal salvation through Christ, but it recognized no sufficient means or provision for the personal knowledge of Christ. Various "apologies" had been written to soften or evade the issue, but the issue remained. It still challenged theology to find a solution at once logical and real, capable of harmonizing the teachings of 


\section{THE PROGRESSIVE MOVEMENT}

Scripture and the rational instincts of faith. I shall necessarily have much to say of this issue when I discuss the Andover controversy.

So far as the progressive movement reached the stage of open conflict, two Seminaries were directly involved Union in its attempt to liberalize the doctrine of Scripture, and Andover in its attempt to humanize, or in the term then used, to Christianize the doctrine of human destiny. Among individuals who stood forth resolutely in behalf of theological progress, especially in this last phase, note should be taken of Theodore T. Munger and Washington Gladden. Dr. Munger was a disciple of Horace Bushnell, and carried over his conception of moral education into the problems of destiny. He was a prophetic voice in the early stages of theological discussion in his generation. His "Freedom of Faith," published in 1883, with an introductory essay on the New Theology was a direct and forceful stimulus to the progressive movement. Dr. Gladden, by profession a journalist as well as a minister, was more clearly and actively identified with the problems of applied Christianity, but his efforts to humanize social and industrial conditions had their initiative and constant support in the humanity of his theology. 


\section{CHAPTER VII}

The Andover Period

$$
\text { 1880-1893 }
$$

ANDOVER AS A STORM CENTER AND AS A WORKING CENTER I

The Opening Phase of the Andover Controversy II

The Andover Movement and the Relugious Public

III

Andover as a Working Center during the Decade of Conflict IV

The Andover Trial and its Results 


\section{CHAPTER VII}

THE ANDOVER PERIOD

I

The Opening Phase of the Andover Controversy

When I returned to Andover in 1880 , fourteen years after graduation, $\mathbf{I}$ found few changes in the outward or inward life of the Seminary, and no sign of the impending controversy. The anticipated reconstruction to which I have referred did not assume controversy as a part of its programme. There had been nothing in the history of Andover Seminary to warrant such an assumption. On the contrary, it was to be assumed that Andover would continue to take its part in such advances and adjustments as would still entitle it to a place in theological leadership. Nothing could have been more unexpected than any exhibition of a reactionary spirit at a time when the theological world was to be called upon to meet its own issues in the new era of progress. As one of my colleagues remarked at a judicial session of the Board of Visitors, "I had supposed that Andover, with its origin, and history, and traditions, was a good institution for the advancement of Christian doctrine." The "Andover controversy" was not out of time; it was simply out of place. It belonged elsewhere. That it should have fallen upon Andover requires a brief word of explanation.

The Andover controversy was not altogether a theological controversy. So much should be intimated at the outset. Personal influences were at work in its inception and throughout its continuance. It would be unprofitable to 
recall in detail this underlying fact, but the fact remains in evidence that the disturbing influences were confined from first to last to a group of persons whose activity and persistence were entirely out of proportion to their numbers or representative character. The group had its headquarters in the Congregational House, in Boston, but whether directed from Boston or Andover was not always apparent. It was an influential group, but more influential than representative. It did not represent any considerable number of the alumni of the Seminary or any large proportion of its constituency in the churches; and after the early period of suspicion and alarm it steadily declined in influence. It can hardly be said to have been at any time responsibly related to the Seminary. The Faculty then in service was a thoroughly united body; and the Trustees, with a single exception, were equally united. To understand how it was possible with such an origin for the controversy to be so long continued, and to be carried out into issues which required for their settlement a protracted legal conflict, one must have some knowledge of the peculiar constitution of the Seminary as a corporate body.

The general catalogue of the Seminary, covering its existence till it was removed to Cambridge, refers to it as a "Theological Seminary in Phillips Academy." The reference was accurate. Phillips Academy, founded in 1778, had like most of the educational foundations of the time a distinct religious intention. In 1795 a special foundation was established in the Academy for divinity students. It was therefore in strict accordance with the original design of the Founders that the Trustees applied to the Legislature in 1807 for authority to receive additional 
funds for the purpose of theological instruction, Madam Phœbe Phillips and John Phillips, Esq., the daughter-inlaw and grandson of the Founder, having obligated themselves to provide suitable buildings for the accommodation of sixty students, including a hall for lectures and a library. The following year a fellow-townsman, Samuel Abbot, established a chair of instruction in Christian Theology. Steps were taken looking to the establishment of other chairs thought necessary for a theological curriculum. Meanwhile the movement on Andover Hill had awakened the interest and to a degree the suspicion of a section of the same religious body, but holding somewhat modified views of Calvinism. There was danger of the establishment of a rival school. The danger was averted by the incorporation, after much discussion and some minor compromises, of the promotors of the rival scheme into the Andover Foundation under the title of "Associate Founders." These Associates contributed the funds, ample for the time, for three additional chairs of instruction, and the funds for an additional building. But the contribution was not unencumbered. It carried with it the acceptance of a board of oversight, known as the "Board of Visitors," three in number, nominated in the first instance by the Associates to serve with them during their lifetime, and thereafter to be self-perpetuating. These Visitors, in the language of the Associate Founders, "were to be the guardians, overseers, and protectors of our Foundation." Their special functions were to preserve unaltered and intact the articles of Association, including the Creed, which had been modified in some particulars to bring into prominence some of the tenets to which the Associates attached importance; to interpret the Creed as occasion 
might require; to examine the professors elected by the Trustees on their Foundation; and "to take care that the duties of every professor on the Foundation be intelligently and faithfully discharged, and to admonish or remove him either for misbehavior, heterodoxy, incapacity, or neglect of the duties of his office." The relation of the Visitors to the occupants of chairs on the original or general Foundation was not clearly determined. The Stone Professorship of the Relations of Christianity and Science, established at a later date, was expressly exempted from the supervision of the Board of Visitors. Keeping in mind the fact that the Board of Trustees was the governing board, it will be seen that this twofold jurisdiction was liable to become at any time the source of friction, if not of contention, partly through the overdefinition of the duties of the Visitors, and partly through the want of full coördination between the two Boards.

During the period of the controversy (1882-92) the membership of the Board of Trustees remained practically unchanged. This Board consisted of twelve members who were chosen with reference to the interests both of the Academy and of the Seminary. They were at this time Hon. Alpheus Hardy, Chairman of the Board until his death, succeeded by his son Mr. Alpheus H. Hardy as a member of the Board, and by Rev. Dr. Daniel T. Fiske as Chairman of the Board; Dr. C. F. P. Bancroft, Principal of Phillips Academy, and Mr. Edward Taylor, 'Treasurer of both the Academy and Seminary; Rev. Dr. J. IV. Wellman, of Newton and Malden; Thomas H. Russell, Esq., of Boston; Hon. Joseph T. Ropes, of Boston; Rev. Dr. Alexander MeKenzie, of Cambridge; Rev. Dr. William H. Wilcox, of Malden; Hon. Robert R. Bishop, of Newton; 
President Franklin Carter, of Williams College; and Rev. Dr. James G. Vose, of Providence.

The Board of Visitors in the meantime, though consisting of but three men, changed its membership more frequently, creating the constant liability that "a single personal variation might change its character entirely." The Board in the earlier stage of the controversy consisted of President Julius H. Seelye, of Amherst; Hon. Charles Theodore Russell, of Boston; and Rev. Dr. William T. Eustis, of Springfield. This was the Board which passed upon the election of Dr. Newman Smyth, rejecting him by a vote of two to one. The Board which rendered the mixed decision in the case of the five accused professors, condemning one and acquitting four, consisted of President Julius H. Seelye, Dr. William T. Eustis, and Jonathan Marshall, Esq. The Board which finally recalled this decision and dismissed the case, consisted of Rev. Dr. George Leon Walker, President; Rev. Dr. Alonzo H. Quint, and Jonathan Marshall, Esq. The personal votes of the members of the Board on these different occasions will be given in their connection. At no time, except possibly the last, was the vote of the Board unanimous. The foregoing facts, if kept in mind, will throw light upon subsequent proceedings.

When in 1881 at the close of the academic year, Professor Park resigned from the Abbot Chair of Christian Theology, the Faculty, following the usual procedure in professional schools in the event of a vacancy, began to make inquiries for the most fit man to present to the Trustees for their consideration. After many inquiries and much correspondence at home and abroad, they presented the name of Dr. Newman Smyth, basing their recommendation 
upon Dr. Smyth's reputation as a broad and critical scholar, upon his theological opinions embodying, as they believed, the best traditions of Andover, upon his wellproven work in the pastorate, and especially upon the intellectual and spiritual power which he had shown through his published works in the sphere of Christian Apologetics. Of "Old Faiths in New Light" (1879) the "British Quarterly" had said: "The present volume is one of those books which mark transition periods of theological thought. It is eminently conservative of orthodox thought concerning the Bible and the Christ, but is so by throwing aside many old modes and presenting, if not in new yet in less familiar lights, their true character and claims. We have been greatly interested in the discussion, in its vigorous grasp, its moral penetration, its completeness and its eloquence. Just as Butler constituted a new apologetic for the men of his day, so men like Mr. N. Smyth are contributing a new apologetic for our own time which, as in Butler's case, consists largely in a newer, broader, and more invulnerable way of putting the question." This book, taken in connection with the volumes on "The Religious Feeling" (1877), and "The Orthodox Theology of To-day" (1881), gave the clearest possible opportunity for all concerned to ascertain Dr. Smyth's theological views as well as to measure his intellectual ability. The recommendation of the Faculty was unanimous and hearty; and after full consideration on their part the Trustees elected him to the chair of Christian Theology with no dissenting vote, one member not voting.

Announcement of the election was made through the public press under date of March 4, 1882; officially through an editorial in the "Advertiser" of that date. In its first 
issuefollowing this announcement, the "Congregationalist" declared the appointment unsatisfactory and thereafter became the organ of disaffection. Under date of March 2, two days before the announcement of his election, a letter was sent by a member of the staff of the "Congregationalist" to a member of the Faculty, calling upon the Faculty to withdraw the nomination, as in the event of the confirmation of Dr. Smyth "the appointment will be criticized publicly and vigorously."

Cannot the Andover Faculty [the letter ran in part] be persuaded to withdraw the nomination of Rev. Newman Smyth to be Professor Park's successor? Without underestimating the difficulty of finding a suitable man for the place, or questioning their anxiety to secure the best man for it, or disputing in the least Mr. Smyth's possession of marked abilities, the fact remains and daily grows more evident, as the news of his election becomes known more generally, that such an election is regarded as a mistake and as an injury to the best interests of the Seminary, which will be both severe and lasting. So far as I have been able to learn how it strikes people, and I have taken some pains to learn, I have heard of only one man who likes it. The best which can be said of it is that it is a most hazardous experiment, and people do not feel that Andover just now can afford to run risks needlessly.

If I understand the situation, Mr. Smyth's nomination is before the Visitors who have not yet confirmed it. They must either confirm or refuse to confirm, or the nomination may be withdrawn. If they confirm, the mischief will be done and the appointment will be criticized publicly and vigorously in a way which will not be pleasant however good-naturedly it may be phrased. If they refuse to confirm, it may be painful for $\mathrm{Mr}$. Smyth and his friends. It is quite sure to be. But if the Faculty could see their way to quietly withdraw the nomination, it seems to me that they would save themselves and Mr. Smyth some annoyance and the matter could drop, so far as concerns him, they beginning to look for some one else. 
This very self-revealing letter brings out clearly two facts - first the narrowness of the circle in which the writer operated (he found but one man as the result of his inquiries who liked the appointment of Dr. Smyth); second, the determination of the group at this early stage not to accept the decision of the Visitors should they vote to confirm Dr. Smyth. It is also a fair inference, from the pressure brought to bear on the Faculty to withdraw the nomination, that pressure was being brought to bear upon the Visitors to reject it. This inference is sustained by a sentence in a personal letter from President Seelye received a little later — "The Board of Visitors, notwithstanding the criticisms with which they have been favored, not to say flooded, have been convinced by Dr. Smyth of his profound agreement with the established doctrinal position of the Seminary."

The chief ground of objection on the part of the "Congregationalist" was a relieving theory put forth by Dr. Smyth in a defense of the Christian doctrine of retribution, to the effect that it was reasonable to believe that those who had had no opportunity to know of Christ in this life, or to come under the Christian motives to repentance and faith might have such opportunity hereafter. The occasion for the introduction of the hypothesis was the challenge of a local club of skeptics to justify Christianity at this point. The "Congregationalist" regarded it as a vague and unsettling theory having no sufficient support in Scripture and contrary to the accepted doctrine of the universal decisiveness of this life. It was charged that this theory constituted "a second probation."

To the mind of this generation it seems quite impossible that so false and contradictory a term as "a second proba- 
tion" should have been made the rallying cry of the alarmist, and still more that within certain limits it should have been an effective cry. But such was the fact. It actually succeeded in bringing together various incongruous elements, confirming the view which I have expressed that the influences at work were "not altogether theological." The title of the editorial in the "Congregationalist," "Professor Park's Successor," showed the nature of the appeal to that type of mind which takes alarm in any change in the method of presenting truth. Professor Park's method was that of the advocate. It was directed to a given conclusion and was satisfied with the most effective means of reaching it. It left a good deal of valuable and really pertinent truth by the wayside. Dr. Smyth's method promised to be that of the interpreter. It seemed to take account of all related truth, and sought to arrive at a more comprehensive result than any that could be reached as the conclusion of an argument. The term "second probation" was also made use of to waken the antagonism of the promoters of missions. There are "vested interests" in dogma as there are vested interests in property. The dogma of the universal decisiveness of this life, involving the perdition of the heathen, was a vested interest of incalculable value in the judgment of certain managers of missionary boards. To question this dogma was in their language "to cut the nerve of missions." It were better to make Christianity unreasonable if not unbelievable. Still further, the term in question was devised and employed for the special purpose of making the hypothesis of Dr. Smyth, regarding the Christian possibilities of the future state, appear to be contradictory to the Andover Creed. As a matter of fact the Andover Creed 
was silent at this point. The subject had not then come under consideration. All that could be said was that, in the judgment of the "Congregationalist," the makers of the Creed would have condemned the theory in question had it been before them. But to say this was to deal in that most dangerous of all creations of the human mind "constructive heresy." From this risk the "Congregationalist" did not shrink, but proceeded to affirm that any one holding this hypothesis could not honestly subscribe to the Creed; and if allowed to subscribe, would subject the management of the Seminary to the charge of perversion of funds. Under this construction of creeds and of credal obligations, the Seminary was conceded to be immovably anchored to a "particular phase of orthodoxy in the past," and it was also conceded that it was the duty of its guardians to hold fast to this anchorage.

In this effort to establish the theory of constructive heresy on which the charge of dishonesty in subscription to the Creed of the Seminary might be based, the "Congregationalist" went so far in its appeal to the prejudices of all opponents of creeds and of creed subscription in general that the Faculty felt compelled to arrest the discussion by showing its sinister motive and its deplorable effect. They justified their action in this matter, while the question of the confirmation of Dr. Smyth was still before the Visitors by saying in the introductory paragraph of their Letter to the public: "While the election of a Professor at Andover is in the hands of the Visitors, it would ordinarily be improper for either the Board of Trustees or the Faculty to engage in a public discussion of it. If we exceed the customary rule in the present instance, it is because the discussion has swept into its 
current questions far broader and more vital than that of the confirmation or rejection of the Professor-elect questions that touch not only the life of Andover Seminary, but the perpetuity as well of all trusts conditioned 'by a creed, and even the possibility of an orthodoxy at once stable and progressive." This letter was signed by all the members of the Faculty in active service. The substance of the Letter was given wide circulation in the daily press. I find in referring to the files of the "Independent," at the time, while it was as yet under the unfettered editorial management of Dr. William Hayes Ward, the most influential organ of liberal orthodoxy, that the Letter was published in full under date of April 13, 1882, with a clear interpretation of the Andover situation. It also appeared in the "Congregationalist" of the same week with editorial comment.

Meanwhile as this discussion went on, Dr. Smyth was still in the hands of the Board of Visitors. Their decision had gone to the Trustees in a tentative form, but had not been made public. It had, however, been foreshadowed in a brief personal interview, following the official examination of Dr. Smyth. As I had been asked by President Seelye, the Chairman of the Board, to introduce Dr. Smyth to the Visitors at their session at the Mansion House, Andover, he courteously called at my house on his way to the station and briefly outlined their possible verdict. This was similar in terms to that finally rendered, and was to the effect that while the Board was fully satisfied with the conformity of Dr. Smyth's theological views with their own interpretation of the Andover Creed, they so far questioned his habit of mind as a teacher that they hesitated to confirm him. Upon Dr. Seelye's asking me what I thought of 
this outcome of the case, I was obliged to answer that it seemed to me that it was an evasion of the essential issue, and that it would be so regarded by the Faculty and the Trustees. My reply, though received with attention, was evidently not convincing.

The following letter to Mr. Hardy, President of the Board of Trustees, gives a suggestion of the discussion which went on between the two Boards while the case was pending before the Visitors:

\section{My dear Mr. HaRdy:}

I thank you for forwarding Dr. Seelye's letter, which please find enclosed. As in his letter to you he referred very kindly to my attitude toward Newman Smyth, I want to give you briefly the reasons which hold me to my record.

1. The election of Newman Smyth unites the Faculty. I do not say that we could not unite upon any other man, but I do not see the man upon whom we could unite so thoroughly and heartily. If I were writing to President Seelye, I should enter quite at length into this matter, but you know the story better than I do.

2. The election of Newman Smyth wakens enthusiasm among students. Of this you have had the testimony. ${ }^{1}$ And in the pres-

1 Andover Theological Seminary March 11, 1888

Prof. W. J. Tecker:

Dear Sir:

The Congregationalist's editorial on "Professor Park's Successor," which came to my notice this morning, suggested for the first time that there might be some opposition to the appointment of Dr. Smyth. As I chance to be almost the only member of my class remaining here, I feel that I should not do my duty by my classmates who have gone away, did I not express to you the intense satisfaction with which the appointment has been regarded by us all. I have also heard from friends in Union Seminary that the appointment meets with similar enthusiasm among the students there.

In case the feelings of the students would have any weight whaterer, I hope that at least no negative action will be taken before we have an opportunity to present the petition, which I know would spring spontaneously from every member of the Seminary, that Dr. Smyth's appointment be confirmed.

Inasmuch as students, though lower, are yet quite as essential members of the 


\section{THE ANDOVER PERIOD}

ent state of philosophic thought it would be impossible to elect any one who would awaken enthusiasm, who would not also waken some opposition. A man might be elected with whom no party, or no person could find fault, but he would meet with an apathy more to be feared than opposition.

3. The election of Newman Smyth gives us a man who can keep up the connection between Andover and the religious public. He has made an audience through his books. Newman Smyth is not an orator like Professor Park. It is a question whether he cannot do a larger and more timely work by his pen than by his voice. But he is a preacher, as his pastorate at Quincy, Illinois, testifies, and as the attempt of the Center Church at New Haven to secure him also testifies.

4. The election of Newman Smyth is the "truest conservatism." So a man writes to us who estimates the impression upon the public. It saves to the Church men who are thinking most deeply, and who feel most the attacks of skepticism.

It is a noticeable fact that no skeptic, no secularist, no man of doubtful orthodoxy has claimed Newman Smyth as a heretic. No man has pointed out the heresy which has been charged upon him. It has been reserved for the friends of Orthodox Christianity, under what seems to me to be an utter misapprehension, to call attention to and emphasize his position in regard to the future.

What was at most entirely incidental, what has its complete explanation in the fact that the work that he was doing was purely apologetic, has been seized upon and held up as a dogmatic utterance covering the whole case. I should apprehend the greatest consequences to the younger ministry from the rejection of a man of such marked conservatism, and constructive tendency. If such a man cannot be accepted in illustration of the

organism of a seminary as professors, I cannot believe that those who have the interests of Andover Seminary in charge, will deliberately disappoint the numerous students both here and elsewhere, who are hoping to complete their preparation for the work of maintaining the old faith in the new light under the instruction of the one man in America whom we have long regarded as best qualified to give us the equipment that we need. 
orthodoxy of to-day then young men will begin to look elsewhere than to orthodoxy for their teachers and helpers.

5. The election of Newman Smyth bears investigation. To go back to his nomination, it was a fact that the reading of his books brought the Faculty into complete unity. It was a fact that he grew by investigation and correspondence in the esteem of the Trustees. It is a fact that the Board of Visitors, "Notwithstanding the criticisms with which they have been favored, not to say flooded, have been convinced by Dr. Smyth of his profound agreement with the established doctrinal position of the Seminary." (Quotation from a private letter from Dr. Seelye.)

Why then should not the "confirmation of Dr. Smyth be with me a matter of strong desire?" I do not think that I am held by the thought of consistency. The reasons which at first suggested his name have grown in weight under the disclosures of the past week.

It did not occur to me when I began to write, that this statement would go beyond yourself, but you are at entire liberty to use it as you think best.

Very sincerely yours

WM. J. TUCKER

In due time the decision of the Visitors was rendered to the Trustees, but in tentative form, that in place of their own proposed rejection of Dr. Smyth the Trustees might be persuaded to withdraw his election. In this communication, according to the report of the "Springfield Republican" based on the text of a copy in its possession, the Visitors declare themselves "convinced of the general harmony of Dr. Smyth's theological views with those which have been identified with the history of the Andover Seminary from the beginning." They are fully satisfied that "he heartily accepts the Creed," and that on the special points raised - as to sin, atonement, and the future state - "he is in substantial agreement with 
the characteristic doctrinal position of this Seminary." They do, however, find it a difficulty that "he seems to conceive of truth poetically rather than speculatively," and fear that this "rhetorical quality would interfere with his precision as a teacher." It is, they say, on these considerations rather than on doctrinal questions that they hesitate and seek for further light. They ask the Trustees to reconsider the matter in view of these objections. The Trustees made prompt reply to this communication through a committee, acknowledging the courtesy of the Visitors in re-submitting the matter to the original Board, and expressing their gratification with the declared approval of Dr. Smyth's theological views, but saying that in their judgment the reasons given for the hesitancy of the Visitors in ratifying his election were not sufficient to warrant them in withdrawing his name, and asking in return for further consideration on the part of the Visitors.

In their second communication to the Trustees, the Visitors made their tentative decision formal and final, somewhat enlarging the statement, but making slight changes in the phraseology already reported. In the minute which they adopted by a vote of two to one, Judge Russell voting in the negative, they say: "The Board of Visitors would again express their conviction that the theological views of Dr. Newman Smyth are in general harmony with those which have been identified with the history of the Andover Seminary from the beginning. After his full and explicit acceptance of the Creed and his frank additional statements in response to our inquiries, it is impossible for us to doubt his substantial agreement with the doctrinal position characteristic of this Institution. 
His natural frankness, his moral earnestness, and his Christian sincerity are too evident to permit us after our conference with him to raise any question upon this point."

The point upon which the rejection of Dr. Smyth turned, as restated officially, was that it is his habit "to use language more as expression of his feelings than of his thoughts, and to conceive of truth sentimentally and poetically rather than speculatively and philosophically." Of this decision Dr. Duryea wrote: "I am sorry for the record of the Visitors. I wish they had acted and given no reasons. The disparity between their encomium and criticism eannot be accounted for on any hypothesis readily suggested to the ordinary reader. This will leave them open to the charge of leaning on both sides, and coming out of a very small crevice, under the pressure they were not able to bring themselves to resist."

Of course there was no way of exposing the fallacy of the judgment of the Visitors regarding the habit of Dr. Smyth's mind, except as it should be made evident through his subsequent career. As that became more and more a matter of public attention, it was seen how capricious the judgment had been. Called at once to the First Church of New Haven, he made the pulpit of that historic church at that academic center a fit complement to the intellectual life of the University. "The imagination and feeling" which illumined and vitalized his preaching, have never disturbed the sanity or lucidity of his utterances. "Preeision of thought" has been his unfailing characteristic. He has been not misunderstood by the men of his own generation or by the successive generations of students who have been drawn to his ministry. And in the larger religious world, I know of few who would be recognized as 
entitled to an equal place among men of so-called "light and leading." No name is more closely identified with the very critical and highly constructive work of ecclesiastical unity than the name of Newman Smyth.

Apparently the decision of the Visitors, in spite of its injustice to Dr. Smyth, was in the interest of theological freedom, but it did not make that impression. There were two reasons why it produced a contrary effect. One was the very general distrust of its consistency if not of its sincerity, a distrust which it is but fair to say was justified by a subsequent decision condemning a professor for holding the same theological views which they had admitted to be in harmony with the Creed. (Exception should be made to this criticism in behalf of President Seelye.) The other reason was the fact that while the decision seemed to settle for the time the question of theological freedom, it opened the question of institutional freedom. For the first time in the history of the Institution, the Trustees were confronted by the liability attending the acceptance of the visitorial system. They were confronted by the system in what seemed to them to be the most arbitrary and capricious exercise of its power. Moreover, it was a keen disappointment to those who had come to know Dr. Smyth personally, and to see what manner of man he was as disclosed by his bearing under the trying circumstances in which he had been placed, that the Seminary was to be deprived of his services. The Trustees were thoroughly aroused by the decision, and at once began to take measures looking to the establishment of a new chair - of Apologetics or of Comparative Theology as might be most agreeable to Dr. Smyth - to be free, after the precedent of the Stone Professorship, from the 
jurisdiction of the Visitors. It was well understood that, although the exemption of the Stone Professorship had been passed by without remonstrance, the establishment of the proposed chair would be legally contested by the Visitors. But the Trustees, as I have said, were fully aroused and were prepared to defend the legality of their action. One of the legal members of the Board went so far as to call in question the full authority assumed by the Visitors over the use of the Abbot Chair of Christian Theology, affirming in a telegram to Dr. Smyth, "Visitors are not final judges of founders' intent and scope of Abbot Chair, and have not veto power over assignment of duties of that Chair by Trustees." The Trustees unanimously, with an exception before noted, asked Dr. Smyth to accept an election to the chair in question, its name and function to be determined by him, and the Faculty urgently seconded their request. As the correspondence of the time shows, Dr. Smyth took the matter into careful and sympathetic consideration, but felt compelled to decline the proposal. To him the controversy had had such theological significance that he feared the effect if it should be given at once a legal bearing. That might come later, but the defenders of theological freedom should not be the ones to give it that aspect, as would be the case if the right to establish a chair outside the jurisdiction of the Visitors should be tested in the courts. The question should be held, in his judgment, definitely and persistently to the theological issue, and if it should be necessary, fought out in such a way as to make it tell most impressively for theological freedom. Such was his judgment at the time, and such is still his opinion as he has taken note of the effect of his decision. In a recent letter he writes: "As I look 
back, I wonder whether my decision then not to accept what the Trustees so valiantly urged, did not providentially result in presenting the issue in its full significance and on better lines than would have been possible, if it had turned simply on my occupying a chair then. I hope you may be able to make some detailed account of the whole matter. . . . The younger men hardly know how their liberty was won for them by the Andover controversy."

I am not disposed to question the wisdom of Dr. Smyth's decision or the justice of his present opinion. I certainly agree with him in thinking that the result actually achieved was greater than could have been gained by the simple acceptance on his part of a chair created for him by the Trustees. Much more would have been necessary on their part - at least nothing less than such a reorganization of the Seminary as would have allowed them to make this new foundation the beginning of an enlarged and free institution through the restriction, or very clear subordination, of the Board of Visitors. This was what I had in mind when I joined with my colleagues in urging upon Dr. Smyth his acceptance of the proposal of the Trustees. Possibly the result even then, had the larger scheme been successfully carried out, would have been no more impressive. To form any comparative judgment as to the relative value of the two possible results, it is necessary to call in the experience of another seminary placed at about the same time in similar circumstances. The two seminaries which bore the brunt of the battle a generation ago for theological freedom were Andover and Union. Each won a notable victory, but Union did not stop short till it had gained institutional as well as immediate theological freedom. It finally set itself free from all "visitatorial" 
control. As a result I think it is evident that Union is today more secure than Andover in its theological freedom, and better equipped in its unencumbered strength for the opportunities and exigencies of the modern theological world.

The inconclusiveness of the decision of the Visitors created a state of uncertainty in the public mind, regarding the immediate future of the Seminary, but no confusion in the minds of the Trustees and Faculty. It seemed rather to unify them, and to give definite shape to their plans. The unexpected and uncalled-for prominence which had been given to the theory of a possible future probation for those who had not had a Christian opportunity in this life, was not allowed to force the theory out of right proportion in the general scheme of Christian doctrine. On the one hand, it was fully understood that the question which had been raised by its introduction was yet to be settled. It was not to be set aside, or held in diplomatic abeyance. On the other hand, it was determined that it should not be forced to a premature settlement. It was not to be made a shibboleth in the further effort to fill the Abbot Chair of Christian Theology. What was to be sought in a candidate for that chair was not a ready-made opinion on the subject which had been so recently in controversy, but rather, apart from the requisite professional qualification, those personal qualities which would demand full liberty of investigation and insure a candid judgment. The special qualities sought for in this emergency were open-mindedness, candor, courage, breadth of view, and intellectual and moral sympathy with the aims of progressive theology. It is doubtful if these qualities could have been more perfectly exemplified than in Dr. George Harris, who was 
now elected to the chair. When questioned by the Visitors regarding the theory of a future probation, he replied with characteristic frankness that "he had not reached a definite opinion," but that he wished "to emphasize the liberty not only of clergymen, but of those who might take the Creed to hold the opinion." The Visitors took no exception to this statement.

There was an untimely, and in every way regrettable, but still unavoidable, sequel to the agitation attending the rejection of Dr. Smyth. I refer to the resignation of Professors Thayer and Mead in protest against certain requirements in the subscription to the Andover Creed. Their resignation was in no sense a logical result or a necessary consequence of Dr. Smyth's rejection. Neither of the professors had the slightest sympathy with the action of the Visitors. But that action had naturally brought into public discussion the whole subject of creed subscription, and in particular the terms of subscription to the Andover Creed. Both of the professors, especially Professor Thayer, were men of a high sense of personal liberty. They had been for some time restive under the general requirement of subscription, but the special requirement which occasioned their protest was that subscription should be repeated once in five years. As the time for the renewal of their subscription approached, they naturally became more sensitive to the requirement in view of existing circumstances, and asked the Trustees to relieve them of the obligation. They argued that as they had once subscribed, and no exception had been taken by the Visitors to their holding of the Creed or to their teaching, the required renewal was not only superfluous, but in a degree humiliating. The demand 
implied distrust or suspicion of the Faculty, in place of that full and unquestioning confidence which ought to be given to men who had proved their loyalty. It tended to confirm the popular impression of literal and slavish subscription. Their contention was not unreasonable, but as I have indicated, it was untimely. It was at least out of harmony with the theory and practice of the Faculty and with the position which they were seeking to defend. Their position in regard to creed subscription was that the requirement of subscription carried with it the right of interpretation. No man was to be required to take the Seminary Creed literally, not even the Visitors, who, though charged with the duty of seeing that it remained unaltered, were equally entrusted with the duty of interpreting it. As in the case of the Justices of the Supreme Court, who might be strict or free constructionists of the Constitution, so the Visitors might interpret the Creed strictly or freely. The right of interpretation granted, the stated renewal of one's subscription, whether Visitor, Trustee, or Professor, was a matter of secondary importance. Each renewal might furnish the occasion for restatement of the meaning of the Creed (at any particular point) to the subscriber.

This theory of creed subscription, supported by the right of liberal interpretation, was the theory entertained by the Faculty, as something to be held and defended by them in their own name and by their own right. The divergence of their colleagues, Professors Thayer and Mead, was to the effect that this right of liberal interpretation should be guaranteed and publicly announced by the Boards of control. In his speech at the anniversary dinner of the Seminary following his resignation, Professor 'Thayer 
said: "I should not be worthy to stay here, if, holding the views $I$ do respecting the intended stringency of that document, and confirmed as I am in these views by the reiterated and persistent reluctance of these official boards of trust, publicly and officially under their signature, to formulate and promulgate the larger liberty which, in after-dinner speeches, they seem glad to encourage, I did not go."

The contention of the Faculty for personal liberty of interpretation was not free from criticism. It called out the sarcasm that it meant "taking a creed in block and rejecting it in detail." To the nautical figure of Judge Russell, a former Visitor, that "no ship was ever so closely anchored that it was not free to feel the rise and fall of the tide," Professor Thayer was able to make fairly the neat rejoinder: "this means that while the Creed remains fixed like the anchor down in the mud, those made fast to it can move about pretty much as they please provided they carry cable enough to pay out." But the contention of the Faculty was none the less the only reasonable defense of creed subscription. The insistence upon personal liberty of interpretation rather than upon the demand for delegated liberty through governing boards, was of the very essence of theological and institutional freedom. As will appear later, it was the contention with which the accused professors faced their accusers at the "Trial," and which changed the whole situation from that of personal defense to an aggressive defense of the Andover Creed and of creed subscription.

Coincident with the election of Dr. Harris to the Abbot Chair of Christian Theology, the Trustees established, under endowments which had already been accepted ac- 
cording to the "Associate" agreement, the two chairs of Biblical Theology and of Biblical History and Archæology, each of great value in the existing state of Biblical criticism and of archæological research. The former chair was filled by the election of Dr. Edward Y. Hincks, and the latter by the election of Dr. John P. Taylor. To the chairs of Sacred Literature (Old and New Testaments), vacated by Professors Mead and Thayer, the Trustees called two recent Fellows of Union Theological Seminary, George Foot Moore, now Frothingham Professor of the History of Religion at Harvard, and Frank E. Woodruff, who after four years at Andover became Professor of Greek at Bowdoin. He was succeeded by Professor Ryder, who remained in full service until his death in 1918. The members of the Faculty already in service were Egbert C. Smyth, Brown Professor of Ecclesiastical History and President of the Faculty, elected in 1863; John Wesley Churchill, Jones Professor of Elocution, elected in 1869; John P. Gulliver, Stone Professor of Relations of Christianity and Science, elected in 1879; and William Jewett Tucker, Bartlet Professor of Sacred Rhetoric, elected in 1880. The Faculty as thus reconstituted remained unchanged throughout the period of the controversy.

The official status of the Seminary at the close of this preliminary stage in the controversy and reorganization, as represented by the Board of Trustees, may be briefly summarized as follows. Having been obliged to give over the plan of establishing a chair outside the visitorial system for the occupancy of Dr. Smyth, which plan would have allowed other free chairs, or involved a lawsuit for the restoration of original rights, the Trustees adopted the policy, now known as that of "watchful waiting," looking 
to the one immediate purpose of giving to the professors and to the public the assurance of theological freedom. Assuming that the Visitors were sincere in their "conviction that the theological views of Dr. Smyth were in general harmony with those which had been identified with the history of the Andover Seminary from the beginning," and assuming that they were sincere in conceding to Dr. Harris full liberty to sign the Creed, while holding the right to accept the "theory of a probation after this life for those who do not have the gospel," they proceeded to the discharge of their duties in the further development of the Seminary, and awaited results.

II

The Andover Movement and the Religious Public

It was two years from the resignation of Professor Park to the inauguration of the successors of Professors Thayer and Mead. One of the most intelligent and well informed of the religious journals of the time was in the habit of referring to the agitation, which was carried on meanwhile, as the "Andover Disturbance." It had not yet become the "Andover Controversy." The distinction was well taken. The agitation during this period was characterized by lack of dignity and of seriousness. The point of attack on the management of the Seminary had been chosen with a view to popular effect. The attack necessarily took the fortune of this choice. The reaction came in the form of response most pleasing to the popular mind. "Second probation" was a term on which the most solemn changes could be rung; it was also a term which easily lent itself to sarcastic and facetious gibes. Another term of disparagement, the "new departure," became in the hands 
of the theological wags, as applied to the future state, the "new aperture." The general subject furnished a constantly recurring theme for the Boston Monday Lectureship under the ingenious and often startling treatment of Joseph Cook. It was a subject which enjoyed in about equal proportion the hospitality of the religious and the secular press.

This early stage of agitation was no time for an unprejudiced or thoughtful hearing for the underlying truth in question. It was a time for restraint on the part of the Faculty. To have been drawn into premature discussion would have contributed only to the confusion of the hour. In due time the "Review," already in plan, would take up the subject with becoming sincerity, and with a due sense of proportion, and bring it into proper alignment with related subjects in the field of theological progress. What was timely and in every way desirable was some attempt to change the tone of popular discussion. The one grievous lack was seriousness. Definition and argument would come later.

It was in the sense of this pressing need that $I$ accepted an invitation, given to me presumably as a representative of Andover, to preach the annual sermon at the meeting of the General Association of the Congregational Churches of Massachusetts at Fitchburg, June 25, 1882. In this sermon, I determined to avoid any premature discussion of "second probation"; to show rather the reason and scope of the Andover movement, and above all to make some definite impression of its seriousness. The sermon was based on the exhortation of the writer of the Epistle to the Hebrews (chap. XII : 28, 29) to his Jenish brethren so far to enlarge their Judaism as to allow them "to be- 
lieve unto Christianity" - "an exhortation," I remarked, "which had its direct significance for every generation like our own called upon in the providence of God to enlarge the scope of its religious thinking, and to change in any essential respects its methods." After showing what I believed to be the occasion for this enlargement in the prevailing theological provincialism of New England, I dwelt upon the qualities necessary to effect it. "Courage and seriousness," I affirmed, were "the qualities necessary to a generation through which in the providence of God any change is to be wrought out in things touching religion - courage to dare to let in the larger life and the larger truth, to open up, to break up, if need be, the formal for the incoming of the more spiritual; seriousness to see to it that every change is wrought as 'under the Great Taskmaster's eye,' to see to it that religion is held meanwhile in the thoughts of men under the power of its eternal sanctions." The sermon evoked much comment, varying from earnest approval to questioning and condemnation. One very zealous clergyman wrote me a long letter denying every exception which I had taken to the current habit of theological thought, and protesting against the publication of the sermon. I think, however, that the utterance then made cleared the air of superficialities and even frivolities, which had begun to mark the opposition in certain quarters to the "Andover Movement," and left distinct impression of its seriousness upon the minds alike of friends and of opponents. I am confirmed in this view of the nature of the impression produced, by the following extract from the "Chicago Advance" which has come to my notice since the above paragraph was written: 
At evening Professor W. J. Tucker delivered a remarkable sermon at the Rollstone Church to an audience that at times seemed literally breathless. His text was Heb. xIr: 28, 29. He began with a bold defense of courage as necessary to Christian thinking, and a solemn assertion of seriousness, as equally essential. After a clear, strong statement of the spiritual and intuitional, as opposed to the mechanical and objective in theology, and after dwelling upon the spirit of our age as deeply conscious of God, he spoke of theories of the future state. The sermon will be printed. It deserves and will receive careful reading. Some thought it a "new Andover platform"; others, that it marked an epoch in New England theology. Others called it mystical, and a few were utterly dissatisfied with it as an attempted but inadequate defense of Andover.

The Andover movement was more than the Andover controversy. It was wider and deeper. The controversy was incidental to the movement, though a large and necessary incident as it proved to be. It was to become in time a fight for theological freedom. The movement preceding and permeating the controversy was a part of the general movement for the enlargement of faith. But if the fight had been declined, it would have withdrawn Andover from the movement. It was difficult to make this fact plain to some of our loyal supporters and friends. They did not altogether like the issue which had been forced upon us. They positively disliked the label of "second probation," overlooking the fact that the attempt to fasten an unpopular term upon a rising cause is a pretty sure sign of the recognition of its vitality and strength. It was, however, none the less desirable to keep the movement plainly before the public mind, to see to it that it was understood in its true proportions, and above all that it was apprehended in its motive and spirit. 
For the carrying-out of this last object, namely, that of spiritual impression, very much depended upon the personal service in the churches rendered by the men from Andover, both Faculty and students. Fortunately the Faculty at the time was to a considerable extent a preaching faculty. Some of the professors were fresh from the pastorate. The suspicion which had been awakened against Andover did not debar the professors from the pulpits of the influential churches. As a rule the New England pulpit was open, and the churches hospitable and receptive. Of course it would have been a breach of hospitality to have carried the controversy into the pulpit, or to have used the pulpit in any way as a medium for propaganda. What was fitting, what was expected, what was desired was the presentation of truth in the spirit of the larger faith and the larger hope. The essential question in the minds of those who listened to the Andover preachers was, what is the spiritual effect of their faith and hope upon them? Do they come nearer to reality, are they more vital, can they reach the deeper depths of the heart? I recall no unnaturalness in the relation between the preacher and his various audiences, no consciousness of the representative above the personal in preaching. On the contrary, preaching was quite as natural to me, and in some respects more stimulating than in the pastorate. I had feared that the tendency would be to pass insensibly from the preacher to the sermonizer. The actual effect was to intensify preaching. There was little interruption in this work of the pulpit. I find in referring to my record that there was hardly a Sunday spent at home, except during the month of the supply of the Andover Chapel, as each one of us took his turn in the supply. For the most part my engagements 
covered a succession of Sundays - at the Old South, Boston, for six months preceding the coming of Dr. Gordon; for an equal time at Berkeley Temple before the coming of Dr. Dickinson, when it was taking shape as an institutional church; for very considerable periods at the State Street Church, Portland, the South Church, Salem, the Kirk Street Church, Lowell, the Central Church, Boston, the Central Church, Providence, the United Church, New Haven; and frequent preaching, but not in succession, in the various college pulpits.

This was very strenuous work, but as I have said, it was stimulating and in many ways helpful. The field became a spiritual and social laboratory. I returned to my classroom not only quickened in spirit, but informed at certain points in regard to the social, industrial, and economic problems which faced the New England churches in the cities and manufacturing towns, and with which the Andover movement had a practical concern. That was to be one form of its application of "theology to life." As I have intimated in an earlier chapter, the humanistic phase of theological development had to do with human conditions in this life, as well as with human destiny. Religious effort in the cities among the people in the segregated neighborhood had taken the form of the mission. Some very satisfactory results had attended this form of religious effort, but undesignedly and for the most part quite unconsciously, it was leading toward that process of social segregation which was fast becoming the acute problem of city life. Increasing familiarity with the churches gave me the opportunity not only of investigating this problem at first hand, but also of consultation with the most active and intelligent laymen. The results 
of these investigations and conferences were to appear in connection with courses of lectures at Andover on social economics, and in the founding of the Andover House, now the South End House, in Boston.

The relation of the Andover movement to Unitarianism was naturally a matter of interest in New England. It never became a matter of denominational discussion. The Unitarians laid no claim to the movement, and no serious charges of Unitarian tendencies were brought by the champions of the old-time orthodoxy. On the part of those most directly opposed to Andover, the obsession of "second probation" was so great, that while it lasted it limited the area of theological vision. When formal charges were brought against the professors, there was little zest in any specifications bearing on other doctrinal points, except in a certain way upon the doctrine of sacred Scripture. There was, however, as I have said, a very genuine interest on the part of many Unitarians to know the attitude of Andover toward their body, as well as to know how the "new" orthodoxy differed from the "old." An occasion, the annual festival of the Unitarian Club of Boston, which was meant primarily to bring out the difference between the new orthodoxy and the old, became unexpectedly the occasion for bringing out quite distinctly the essential line of cleavage between the new orthodoxy and Unitarianism. Dr. Lyman Abbott, Dr. Gordon, and myself had been invited to speak as representatives of the new orthodoxy. Dr. Abbott made the opening address. He gave a very clear and comprehensive exposition of the Puritan theology as based upon the conception of the Sovereignty of God, and applied this inherited theology to both the old and the new orthodoxy. Toward the close of his address, he gave at 
some length his personal conception of the divinity of Christ as inherent in his humanity, because the divine and the human are one in essence. To this utterance both Dr. Gordon and myself, as expressing the faith of the new orthodoxy, took exception; so that from this point on, the discussion turned from the distinction between the old and the new orthodoxy to the distinction at the most vital point between the new orthodoxy and Unitarianism. I give a brief extract from my speech following Dr. Abbott's, and also from the speech of Dr. Gordon who followed me:

I had not expected to speak directly on the subject that has been introduced here to-night with so much reverence and tenderness; namely, the person of our Lord Jesus Christ. I think that I should agree with very much that Dr. Abbott has said throughout his address. I think there is a sense in which I should not agree with what he has said at this point. We are like God; there are a great many things which are the same to us and to Him. "Which thing is true in Him," said the Apostle John, "and in you." But there is a difference. We are not God. Somewhere there is a line between man and God; and my question is this, Did Jesus Christ cross that line from below or did he cross it from above? When I try to answer that question, I note this. It is to me a startling peculiarity in the life of Jesus Christ that he was not a seeker after God, that he was singularly destitute of aspiration. The greatest soul in humanity manifests its greatness by searching and reaching out toward God. Jesus Christ calmly says, "He that hath seen me hath seen the Father"; "Come unto me all ye that labor and are heavy laden, and I will give you rest." There must have been a sublime consciousness, an infinite repose of knowledge, a conception that he knew God at the very heart, that enabled him to say, as he came among men, " I am come that they might have life, and that they might have it abundantly' - I want nothing myself: I have all - I am the life, and it is all for man." I stand in awe before that marvelous representation. I know not what that 
life is unless it be the life of God. I can find nothing above it. It reaches into the heart of the Eternal.

Dr. Gordon who followed me said at this point:

I accept the Nicene Creed as the most magnificent symbol of Godhead that has yet come into Christianity. That, I understand, differentiates me from my Unitarian brother, whom I respect from my heart, and whose character may be beyond mine, whose services to the community I may be profoundly thankful for. But as I have said, those who accept in any true sense the Nicene Creed are in their fundamental doctrine of God, and inferentially in their Christology, opposed to and not at one with those who reject that creed.... My profound conviction, which I dare to utter here to-night because you have honored me by asking me to do it, is that it is absolutely impossible, if I believe in the integrity of the records which give His life, for me to classify Jesus as simply a man. He is unclassified to me. There is a uniqueness in Him which cannot come under the mere category of man. When you have asked me to tell you what that uniqueness is, you simply step beyond the legitimate power of question; for I have already said knowledge is simply classification, and I have no class under which He can be brought. I end simply on the line of thought which differentiates, in my judgment, on this momentous question, the New Orthodoxy from the Old, and the New Orthodoxy from the Unitarian body, whose history and character and manhood we are all proud of, we are all grateful for.

I was very much gratified, as showing how genuine the interest was in the modern orthodox view of the person of Christ, to receive after the meeting a letter from Mr. Arthur T. Lyman, President of the Unitarian Club, from which I make the following extract:

I should esteem it a great favor and privilege if at the April meeting of the Unitarian Club (Wednesday, April 13th) you would state much more fully than when Dr. Abbott spoke, your 
views of the person of Christ. We have had Professor Everett who stated one view of the matter plainly, and Dr. Abbott who at the Club and at the Lowell Institute, has stated his view with all the clearness perhaps that it is capable of. I take it that the view of Dr. Abbott cannot be considered to be the general one even of scholars of the orthodox Congregational body. I suppose that Andover does represent the modern scholarly belief of the orthodox Congregationalists, and I wish that we could hear their view fully and distinctly stated. As nearly all of our churches grew from the orthodox Congregational root, we naturally and in fact feel a greater interest in that body of Christians than in any other.

It was with sincere regret that I was obliged to decline this generous invitation, but I found much satisfaction in personal conversation on the subject with Mr. Lyman, whom I came to know with some intimacy and with a constantly increasing esteem, through rather frequent preaching at King's Chapel, where Mr. Lyman was Chairman of the Church Committee. King's Chapel held so unique a place in his judgment in the Unitarian body, that it was with difficulty that I could persuade him that a man of my views of the person of Christ could not consistently allow himself to entertain the thought of considering the pastorate of that church.

Had I been able to accept Mr. Lyman's invitation to discuss at length before the Unitarian Club my conception of the person of Christ, I should have based my reasoning on the distinction drawn by the editor of the "Christian Register" between the orthodox and the Unitarian method of approach to the subject; that whereas "Orthodoxy even in its newest phase approaches the problem of (His) existence from the side of God, modern Unitarianism is disposed to look first at the known and near facts; it studies 
man; its aims and hopes are to search God through man." I should have accepted that distinction as fundamental, involving a radical difference of view respecting the Scriptures. To my mind the person of Christ represents God revealed, not God attained. There is great significance to me in the saying of Lacordaire - "Jesus Christ is the greatest spiritual phenomenon ever naturalized in this world." I have elsewhere brought out my conception of the person of Christ in two monographs - one entitled "Life in Himself, a Meditation on the Consciousness of Jesus," preached as a Christmas sermon (1891) in the First Church, Cambridge, repeated in Andover Chapel the following month, and published as an article in the "Andover Review" for February, 1892; the other, entitled "The Satisfaction of Humanity in Jesus Christ," an editorial in a series on "The Divinity of Christ" in the "Andover Review" (January, 1893), forming the last chapter in the book under that title.

As the controversial situation developed, there was special need of an authorized and adequate organ of communication with the religious public, one that should afford some security against misrepresentation, one that should enable the Seminary to fulfill its part in the theological advancement of the time. Some of our supporters strongly advocated the establishment of a religious newspaper, but this project seemed to us to be inadequate, and in other respects unsuitable. It was fraught with unpleasant liabilities. As one of our most sagacious graduates, Professor Palmer, of Harvard, wrote us, with a wit savoring of wisdom, "A religious newspaper is not necessarily wicked, but it is quite likely to be such in fact." The publication to emanate from a Seminary, according to tradi- 
tion and fitness, was a Review, but in our case it should be a Monthly, not the conventional Quarterly. The way had been prepared for such a publication, without local rivalry or controversy, by the transfer of the "Bibliotheca Sacra," for nearly forty years under the editorial direction of Professor Park, to the associate editor, Dr. George F. Wright, and the removal to Oberlin where Dr. Wright was Professor of New Testament Literature. At the close of 1883, the following prospectus of the "Andover Review" was put out stating its purpose and method:

The publication of a new Religious and Theological Review with this title, will be commenced in December of the present year. While it will appeal to professional readers, it will address itself directly to the religious public.

The Review will advocate the principles and represent the method and spirit of progressive Orthodoxy. Accepting the distinction between theology and practical religion, the Editors will seek to utilize the gains to theology from the accredited results of scholarship in Biblical and historical criticism; and also to show the obligations of theology to the social and religious life of the time. The object of the Review will not be controversy, nor mere speculation. The editors hope to make it a positive and constructive force in the sphere of opinion and belief. Recognizing, however, the fact that no age can honorably refuse to face the more serious problems which confront it, there will be no hesitancy in candidly investigating and discussing the vital questions of the present. The Andover ReriEw finds a reason for its establishment in the number and urgency of these questions.

The Axdover Review will be under the editorial control of

Egbert C. Smyth

William J. Tucker

Edward Y. Hincks
J. W. Churchill

George Harris

Professors in Andover Theological Seminary, Andover, Mass., 
with the coöperation and active support of their colleagues in the Faculty - Professors John P. Gulliver, John P. Taylor, George F. Moore, and Frank E. Woodruff.

The Axdover Review will be published monthly at $\$ 3.00$ a year; single copy, 30 cents.

Houghton, Mifflin and Company

4 Park Street, Boston, Mass.

As the prospectus indicates, the "Review" was not issued under the management or the direct sanction of the Trustees, nor was the whole Faculty to be equally responsible. The five named as editors assumed directly the editorial, and indirectly the financial responsibility, but their colleagues coöperated with them steadily and heartily. Of special value were the contributions of Professor Moore, covering a wide range of critical scholarship, and the Archæological Notes of Professor Taylor. I mention also a co-worker whose name does not appear on the cover, but often within, - Professor C. C. Starbuck, not formally connected with the Seminary, but a scholar of such erudition, and a man of such wide and ready information, that as I look back upon some of our editorial emergencies, I doubt if we could have escaped without his ever ready and always sufficient aid. His range as an authority on religious subjects ran from the more intricate workings of the Roman propaganda, to the remotest operations of the foreign missionary boards.

Among the contributors then and soon often announced, who were really identified with the "Review" as its supporters, were very many representative scholars and writers of the liberal type of theology. The "Review" served to call out and in a sense to organize the advocates of theological freedom and progress within the so-called 
orthodox bodies. A curious incident, showing the unreliability of early associations in determining new alignments, came up in connection with a question of Mr. Houghton (Houghton, Mifflin \& Company) about our list of contributors. "Would you accept articles," he said, "from such men as James Freeman Clarke and William G. T. Shedd?" Noticing our surprise at this collocation of names, he reminded us that he and Dr. Shedd were classmates at the University of Vermont under President Marsh, the most pronounced disciple of Coleridge in this country. Both of them imbibed the philosophical teachings of the classroom. To the mind of Mr. Houghton that fact ought to have fixed the theological position of his classmate in current discussions - a wide miscalculation.

The Andover Review Company, Incorporated, included a considerable number of prominent laymen in New England, among whom were Rowland Hazard, Alpheus Hardy, Samuel Johnson, S. D. Warren, Horace Fairbanks, John N. Denison, F. W. Carpenter, A. D. Lockwood, W. W. Brown, S. R. Payson, S. L. Ward, Henry Woods, Edward A. Strong.

We were much indebted to our publishers, not only for the guarantee which their name gave to the general character and quality of the "Review," but also for their personal interest in the venture. It was a gratification to us, for their sakes as well as for our own, that they were soon able to make the following announcement regarding its reception:

The Axpover Review is the recognized representative, among the reviews, of progress in the advocacy of the Christian faith. Its contributors and readers are from the growing constituency of clergymen and laymen in the various denominations, 
who believe that the safety of the Church and its power lie in the resolute advancement of Christian doctrine in its broadest application to the problems of society. The Review is open to the discussion of all subjects of social, educational, and literary importance, which are germane to the moral and religious life of the people. As an evidence of the scope and interest of its articles, it may be stated that The Review is taken in 250 College and Public Libraries throughout the country.

Notices from the press followed from time to time, of which examples are given in the accompanying footnote. ${ }^{1}$ The distinguishing feature of the "Review" as a religious and theological magazine was its use of the editorial. In this respect it was an innovation upon existing usage.

1 The Andorer Review comes near to being an ideal religious magazine. We know of no other similar publication that more faithfully represents the dominant convictions of the great masses of Christian people concerning the life, duty, and conduct of practical religion. - The Churchman (New York).

There is no abler or more discriminating publication than the Andover Reriew. There is none which the wide-awake minister can so little afford to be without, and whoever, minister or layman, is long conversant with this monthly must become an intelligent and progressive Christian. - Zion's Herald (Boston).

The Andover Review more than fulfills its high promise. Liberal and progressive in its tone, religious questions of vital interest are discussed in a thoughtful spirit by some of the ablest writers of the time. - The Week (Toronto).

In these days when a coarse and blatant infidelity is too often opposed by nothing stronger than a weak religionism, it is refreshing to read a religious periodical like the Andover Review. It is at once a manly organ of essential orthodoxy, and an honest exponent of the legitimate conclusions of modern religious thought. . . . The editorial articles of the Review are admirable. - Newo York Tribune.

The editorials in the Andorer Review are an important feature. Written mostly by the professors at Andover, they touch the nerve of the religious consciousness of our time. - Boston Herald.

One of the foremost of American religious magazines. The Reriew is conducted with conspicuous ability, and numbers among its contributors many of the most eminent thinkers of the day. - Charleston News and Courier.

It is almost necessary for any paper that tries to keep apace with advanced thought as wcll as with the occurrences of the time to draw fully on the inspiration in the Andover Reriew. - Editor of a leading daily paper.

It has been the means of furnishing more inspiration, higher ideals, a more determined purpose in the work of the ministry, than almost anything else which has been published. - A New England Pastor. 
But a Review consisting exclusively of contributed articles, however valuable in themselves, could not give that direct and intimate contact with the religious public which the circumstances demanded. The editorial was capable of a directive force impossible in any collection of articles. And as embodying in a more distinct and continuous way the personal element, it invited a sympathetic reading. Of course there was danger in the exercise of editorial freedom. It was obviated in part, in the present case, by the fact that the editorial utterance was that of a group rather than that of an individual. Still there were liabilities. One day, during the trial of the accused professors, a very stanch friend of the Seminary said to me in good-humored impatience, "The trouble has all come out of your confounded editorials." "Perhaps so," I replied, "but have you thought that it is much more likely that the outspokenness of the 'Review' prevented an inquisition in the classroom?"

As the event proved, the use made of the editorial was justified by two distinct advantages which it conferred. First, it enabled the "Review" to carry out a definite and consistent purpose as an interpreter of progressive orthodoxy. Not all the advocates of theological progress emphasized the same points. It fell to the lot of Andover to emphasize the need of a restatement of the distinctive Christian truths in the more enlarged terms of Christianity. The attack upon Andover was in reality a challenge to this task. The particular question which lad been forced upon the Seminary was not to be evaded when once the conditions were ripe for its discussion.

The opening words of the first issue of the "Review," in the introductory article by Professor Smyth, were a 
quotation from one of the greatest of the early Christians - "Let us learn to live according to Christianity ... for Christianity did not believe into Judaism, but Judaism into Christianity, that every tongue which believes might be gathered together unto God." "These memorable words," said Professor Smyth, "define the theological as well as the ethical and practical purpose of this Review. They connect theology with life. They point out the path to unity of religious belief. They suggest the need and indicate the method of a Christian construction of Christian doctrine. Let us learn to think according to Christianity." In their endeavor to realize the theological significance of this sentiment in the conduct of the "Review," the editors laid down the postulate that "the true and ultimate test of all theological progress is its Christianization of its materials from whatever source they may be derived." All advance, that is, in Christian doctrine depends upon the willingness to recognize and the ability to use the advances in Christian knowledge.

With reference to several of the topics to be considered by us [they say], it should be borne in mind that as distinct, specific and absorbing questions of theological discussion they belong to the modern era....

The question, What is the Bible? could not earlier be investigated as in recent days, for lack, apart from other reasons, of the requisite critical apparatus. The doctrine of the Atonement even in so late a Confession as the Westminster - the last of the great historic creeds - is merged in the larger doctrine of Redemption. Many questions in eschatology, now rife, have never until recently received thorough consideration. The special inquiry as to the relation of Christ's Person, sacrifice, final judgment, to those who never hear the gospel in this life is becoming more and more urgent and important, because it is the next and necessary one, now that the Atonement has become a 
distinct and specific doctrine, and the interpretation has won general approval that it has an absolutely universal relation and intent. We claim in that portion of our work which will naturally attract the most criticism, to be pursuing the path opened by our predecessors in vindicating the now accepted truth that Christ's sacrifice on Calvary was for every man. It is a reasonable request that this connection and relation of what we have to say on eschatology should be kept in view, and that the conclusions reached should be tested by their harmony with the revelation given in and through the Incarnation. The ultimate question between conflicting opinions must be, Which most perfectly appropriates the grace and truth revealed in Christ? We do not decline the test of orthodoxy, but it is obvious that, with reference to inquiries which could not arise at an earlier stage of Christian knowledge or doctrinal development, and which have never been adjudicated upon ecclesiastically because never fully opened for discussion, the question of orthodoxy happily merges in the more profitable question of truth.

In due time the subjects in Christian doctrine here referred to were taken up editorially in the "Review." The editorials soon reappeared as chapters in the book entitled "Progressive Orthodoxy," and were made the basis of charges in the heresy trial which followed. As showing how fully the idea of unity and consistency of treatment was realized, I append to the subjects which form the headings of the chapters the names of the writers:

The Incarnation, Smyth.

The Atonement, Harris.

Eschatology, Harris.

The Work of the Holy Spirit as related to the Historic Christ, Tucker.

The Christian, Tucker.

Christianity and Missions, Smyth.

The Scriptures, Hincks.

Christianity Absolute and Universal, Harris. 
It may be a matter of interest to some to know, in view of the issue of the trial of the various writers before the Board of Visitors, that the specifications on which Professor Smyth was condemned and the others were acquitted, were mostly taken from the chapters written by the other professors. Of course the equal responsibility for the book was shared by all the writers, but the analysis given shows the grotesqueness as well as the injustice of the decision.

A second series of theological editorials followed at a later stage, which was also put into a book under the title "The Divinity of Christ." In introducing this series, the editors say:

Nearly eight years ago we found a similar practical call for an application of a great principle of Christianity, that of its universality to various doctrinal and missionary problems of the day. The papers thus elicited were afterwards gathered together in a little volume entitled "Progressive Orthodoxy." In it the opinion was expressed that the question which "lies nearest the heart of all modern Christian thought and life is ... 'Is the Jesus whose life we know on its human side the Christ in whom religious faith finds its appropriate and permanently satisfying object?"' And we added as expressive of our own conviction "The Jesus of history is the Christ of faith; the Christ of faith is God revealed and known." The chapters which follow will deal especially with the question thus proposed.

Another use of the editorial, which proved to be of equal advantage, was that it enabled the "Review" to take an active and timely part in those phases of the controversy which were not under the restriction of the visitatorial or legal procedure. The formal attack upon the accused professors virtually brought the "case" down to the charge of violating their obligation to the Andover Creed. It left 
the larger theological issues in the open, a matter of free discussion. It was however, given a new setting as it was appropriated and taken in charge by such advocates of foreign missions as held that the Andover theory had "cut the nerve of missions." The American Board, at that time a close corporation, was taken possession of and made the chief agency for continuing the theological attack upon Andover. It was a tactical mistake. It invited and aroused a vigorous counter-attack on the part of the whole liberal element in the denomination which supported the Board, whether it was affiliated with Andover or not. It made the platform of the American Board the arena of a conflict, wider in its interests and more intense in its character than that which was then going on in the courts. In this conflict the "Review" could properly bear its part, and this it was able to do with continuous and cumulative effect through its editorial pages. The conditions were now reversed. The opposers of Andover were put upon the defensive. They had put themselves upon the defensive in the new responsibilities which they had assumed. The original dogma of "the universal perdition of the heathen," which had been put forth as "the real basis of missions," had caused a growing revolt of the Christian conscience among the friends of missions. What relieving theory could be held which should at once justify and stimulate the work of missions? Andover had claimed "that the Christianity of the Bible points to a Christian opportunity for the race, that it lifts the race to the place of grace." It substituted hope for despair as the motive for missions. It affirmed the justice of a true Christian opportunity to every man before he should pass under the final judgment. To this definite and satisfying reliev- 
ing theory, it now became necessary that some reply should be made. It was no longer enough to deny it or denounce those who held it. What could take its place? The only relief actually offered was such as might be found in the theory of "the essential Christ," a vague and shadowy doctrine lacking the force of reality, as it was in its nature destitute of the power of motive. Furthermore, the controversy was now carried on, not through discussion alone, but through "cases," as young men and young women made application for missionary service under the Board, where careful note could be made of the questions to which they were subjected, outside and beyond the standards of the churches that they represented, and where the grounds of their rejection, if for theological reasons, could be put before the religious public. And finally, the controversy reached the point where the Board was obliged to answer to its "relation to the churches - whether it was that of domination or of dependence." In such terms, the controversy ran month after month through the "Review," turning, if not away from Andover, yet into new channels and toward a new outlet - with what effect will appear in the concluding section of this chapter.

To these advantages which the use of the editorial gave to the "Review" in the part taken by the editors in the controversy, I may fitly add the effect of editorial writing upon the editors themselves. It gave a certain directness and naturalness to their professorial work. It was a corrective to any tendency to scholasticism. It had also a broadening effect in compelling a wider knowledge of current topics than merely professorial interest would require. The range of subjects which came under legiti- 
mate, if not necessary, editorial treatment was large. It was impossible to have a narrow outlook upon the human aspects of religion, or to take a narrow view of the increasingly sensitive "contacts" of theology with life.

There was a phase of the Andover editorship worthy of special recall in any autobiographical notes, namely the personal relations of the editors. The editorial work of the "Review" was in a peculiar sense team-work. It brought together men for a distinct, and as they believed for an imperative, task. But as it happened, they were men of congenial thought and temper, and as they became more committed to their work they became more devoted to one another. The intimacies of friendship grew with the increase of responsibilities. Each man kept his individuality, but all felt alike the educating effect of their associated work - the training away from mere scholasticism, the discipline of trying to connect theology with life, and perhaps more than all else the sympathetic sense of the relations and interrelations of religious truth.

Professor Smyth, to whom I shall refer later as the outstanding figure of the group in the trial for heresy, was editor-in-chief, and for the most part the managing editor - a man of profound convictions, broad-minded, but capable of an intense single-mindedness in the pursuit of a given end; an honorable opponent, but dangerous because so sure of his premises and supporting facts; a scholar without the affectations of learning; a man of moral fiber coupled with a rare tenderness of spirit; always sincere, at times ardent in expression. Though lacking somewhat in the "imaginative" quality of his brother Newman, his thought was imbued with a certain power of sentiment, which if not a substitute for the imaginative quality, gave 
a penetrating as well as carrying force to his utterances and writings. To those who knew him intimately, it was a pleasure to note how easily his mind found rest and satisfaction in his æsthetic sense, whether directed toward nature or religious art.

Professor Harris was the most versatile of our group. Richly endowed with the philosophic temperament and well trained in the philosophic habit, he was always lucid and sane. But his range of observation was so wide, and his observations so quick and keen, that he was as invaluable in the discussion of current questions of moral and religious import as in the treatment of theological topics. Noreover, his style was delightfully self-revealing. It photographed his mind in the free play of his action, catching the shades of humor which came and went with the ready flow of his thought. Many of the more general subjects of which the "Review" took note might have been assigned indiscriminately to either Professor Harris or to myself. As I have been looking over the editorials of this class and have been unable to identify the authorship of some one of them by subject, it has usually been easy to identify it by style. Whenever it has shown some peculiar incisiveness, some deftness of touch, some statement carrying its evidence on its very face, I have known that the editorial in question belonged to him rather than to me. The great characteristic of Professor Harris's controversial method was its unanswerable reasonableness. $\mathrm{He}$ never lost his poise. Controversy never jostled his mind. His mental machinery was never thrown out of gear. To argue against him was as if to argue against things fundamental - common sense, reason, and self-evident truth. 
Professor Hincks was remarkably adapted to meet the unusual requirements of his department, Biblical Theology, and to give the right public exposition of them in the "Review." The work of Biblical Criticism required at that time a genuine combination in the Biblical critic of conservatism and radicalism - of radicalism rather than of simple progressiveness, because it was not simply work in advance of what had gone before in the same general department, but relatively new work, work at the roots. Professor Hincks was both a conservative and a radical. His conservatism lay in the depth of his spiritual nature, in his sense of the value of truth spiritually discerned through humility and reverence; his radicalism lay in the fiber and temper of his mind, a mind entirely capable of facing facts, so downright and determinedly honest that nothing could stop it on its way to a decision according to evidence. The editorial writing of Professor Hincks was by no means limited to the treatment of subjects connected with his department (he had made himself quite an authority on certain phases of English politics), but his editorials on Biblical subjects carried the weight of reverence and honesty. Supported by the contributed articles of Professor Moore, they gave the "Reriew" standing among the then modern Biblical scholars.

Personally, Professor Hincks brought to his associates the very enjoyable qualities of ready wit and of an equally unconscious humor. One day during the legal trial, as several of us were starting for Boston to listen to the argument of Professor Gray, of the Harvard Law School, before the Supreme Court of Massachusetts, Professor Hincks boarded the train at the last moment holding a child in his arms and leading another by the hand. "Why, Hincks," 
I said, "what under heavens are you taking the children along for?" "To appeal to the sympathy of the jury."

We each had bound sets of the "Review" in which we took quite a little pride, his bound with a blue morocco back, and mine with a red. One volume as it came back to me was badly marked and disfigured by interlinings and erasures. As these were mostly in one of his editorials, I had no difficulty in tracing the markings to their source. Upon showing him the volume, I said that they must have mixed our copies at the bindery. "Why, yes, so they have; but never mind, I can copy the markings into my set. It won't be much trouble." I value that "marked copy" as the most pleàsing human document in my possession.

Professor Churchill was a liberal. Liberalism stood for breadth before and after the progressive movement was inaugurated. If Professor Churchill had been an Englishman he would have been identified with the Broad Church. His affiliations were with those of that type of thought and faith in this country. "Liberal" and "progressive" are not exactly equivalent terms. There may be breadth without much movement, and any given advance may be narrow and specialized. But liberal may be regarded as the more inclusive term. So it certainly should be regarded as I apply it to Professor Churchill. He was not a strenuous advocate of the Andover tenet of a Christian probation. He simply accorded it the rights of hospitality in his theological holdings. In defining his position before the Board of Visitors, he said: "I earnestly claim for my colleagues their liberty of opinion, teaching, and discussion concerning this hypothesis. More than this I believe that there is reason and Scripture in it. But I have not yet found the 
term 'probation' a necessity for my theology or my view of life here or hereafter." According to the more distinctive liberal theology, he preferred to regard the earthly life as a period of "moral education." The work of Professor Churchill on the "Review" was mainly on subjects to be classed under "Literature and Life." His contributions were in many instances very careful studies. Such, for example, were his editorials on Matthew Arnold, Wendell Phillips, Phillips Brooks, Bishop Simpson, and others in like relation to public life.

Professor Churchill was an Andover man, to the manner bred if not born, a graduate of Phillips Academy as well as of the Seminary and a teacher in both from the time of his graduation. My intimacy with him began in our student days in the Seminary, and was maintained during the intervening years, till it was resumed in the close companionship of our service as colleagues in the homiletical department. He was a great friend. I never knew a man with a greater capacity for friendship. It was the kind of friendship to lighten labor, to stimulate to good thoughts and good acts, to help one to keep faith in human nature.

I have introduced these brief personal sketches of my editorial colleagues as having a fit place in autobiographical notes, for the personal relations which the ten years of editorial service established were intimate and lasting. Not long ago I received a letter from one of the group, who like myself had gone over in later years into administrative service, in which referring to the "good old days of the Andover Review," he added, "Not that I would say the former days were better than these, but in respect to friendships and the 'cause' they were the golden days of my life." 
The religious public to which the Andover movement was most directly and in a sense most responsibly related, was represented by the churches which belonged to the constituency of the Seminary. Whenever an Andover student was now called to the pastorate of one of these churches, he was considered in an unusual degree as a representative of the Seminary. According to an ancient and binding custom of the churches of the Congregational order, a candidate for the pastorate of a church was examined in his theological beliefs by a council made up of representatives of the neighboring churches. This custom was observed with scrupulous fidelity. The examination was conducted in public, and was carried on with an interest and often with a zest seldom seen in the passing of academic tests. It was not to be supposed that an Andover man would escape this ordeal. To the ministers present it was the opportunity, as they assumed, to learn almost at first hand what were the teachings of the classroom. To the congregation, it was a welcome occasion for coming into an understanding of the effect of his theological views upon the spiritual life of their chosen pastor. I was frequently invited to be present and take part in these councils. They were, I think, as informing to me as to the others. I often wondered at the maturity and independence of thought displayed by the candidate. I never detected any mere repetition of the teachings of the Seminary. There was seldom any evidence that the candidate was making statements or answering questions in a representative capacity. It was only the things which were real to him that statement or question revealed; and this selfrevealing process was always impressive. It was influential in shaping the opinions of the councils. It carried convic- 
tion to the great majority who watched it. Frequently the decision of a council was unanimous in favor of the candidate. I recall no instance in which an Andover man was denied ordination or installation, even in the most exciting periods of the controversy.

The experience of students seeking missionary service was entirely different. The American Board was at that time, as has been said, a close corporation. The Prudential Committee, its executive board which passed upon all applicants for missionary service, held its sessions in private. Previous to the presentation of these "cases" to the Prudential Committee, they were "handled" by the Home Secretary of the Board according to what had become the conventional method.

This use of the corporate power of the American Board was not in accordance with its original intention or with its traditions. The incorporation of the Board was for the purpose of recognizing and insuring the breadth of its purpose. It was to be an undenominational body, including especially Presbyterians and Dutch Reformed as well as Congregationalists. Its prudential committee was not to be a theological tribunal. Its secretaries were to be, as had been the case, statesmen in the administration of missions, not partisan propagandists. But the Board had fallen upon a time when the organization had lost the reason for its undenominational character, and yet had not assumed the safeguards of denominational control. This was the time in which it was taken possession of by theological partisans for partisan ends, under whose domination the suppression of the Andover heresy was of greater account than the prosecution of missions; or to state their position most charitably, missions could not be prosecuted if the 
new heresy was not suppressed. If allowed, it would "cut the nerve of missions."

The following letter from the Honorable Alpheus Hardy, declining a reëlection to the Prudential Committee of the Board, discloses the situation as one saw it from the inside:

To the President and Corporate Members of the American Board of Commissioners for Foreign Missions -

BRETHREN: I fully appreciate the honor you have conferred upon me in declining to accept my resignation, and in reëlecting me upon the Prudential Committee.

I believe there has been during the past few years a divergence in the practical management of one part of the Board's work, which has, to some extent, brought the Board from its broad, catholic, "undenominational," and charitable position to be a partisan in questions that are not within its province, are local, in a measure personal and divisive. With such a policy I cannot agree, and believing it to be detrimental to the best interest of the Board, must decline to be a member of a body upholding it, viz. the Prudential Committee.

I remain with respect, now and ever, your co-laborer in the work to which every follower of Christ is commissioned

Boston, October 18, 1886

Alpheus Hardy

In communicating this letter to the public, according to Mr. Hardy's personal request, President Mark Hopkins made a somewhat extended statement on his own account, confirming the statement of Mr. Hardy, explaining more at length the reasons for the existing difficulties in the Board, and advocating as the only method of relief the transfer of the theological examination of missionary candidates from the Prudential Committee to the councils of the churches. The policy which President Hopkins advo- 
cated received growing support, from the constant acceptance by councils of the rejected candidates of the Prudential Committee as pastors of churches, until, as will appear later, the policy was merged into the larger change, through which the Board ceased to be a private corporation, and was made a representative body. The most striking and influential incident in effecting this change was what was known as "The Case of the Reverend William H. Noyes." The case of the Reverend Robert Hume, an honored missionary of the Board in India, who was at first denied a return to his post while on leave of absence in this country, for having expressed sentiments in harmony with the "Andover theory," was a still more serious and influential incident, but it was of different order.

William H. Noyes, the son of a missionary, and his classmate Daniel T. Torrey (Andover, 1887), applied during their last year in the Seminary for acceptance as missionaries of the American Board. The Prudential Committee declined to accept them on the ground that they entertained what they believed to be " a reasonable hope that the love of God in Christ will be revealed after death to those who have not known Christ in this life; this hope being entertained as a necessary corollary of the doctrine of a universal atonement." After being informed that they could not be accepted as long as they entertained this "liope" or "inference," they turned to the pastorate, hoping at some later time to be able to realize their missionary purpose. Mr. Torrey was ordained by a representative council of churches as pastor of the Harvard Church, Dorchester. Mr. Noyes was called to serve temporarily as an assistant at the Berkeley Street Church, Boston. Dur- 
ing this year of service, an unusual interest in missions was awakened in the Society of Christian Endeavor connected with the church, by an appeal from Japan in the "Missionary Herald." After stating the great spiritual necessities of large portions of the country, the appeal declared, "This desire for missionaries is not one of a single night only; it is a constant and unquenchable thirst." As this appeal was read at a monthly missionary meeting of the society, the minds of those present turned spontaneously to Mr. Noyes. "Why can we not send him? Let us petition the church to make him their missionary." The church, of which Dr. Dickinson was pastor, an ardent advocate of missions, a corporate member of the Board, was very much moved by this request, and after due consultation with various pastors and friends of missions, among whom was Dr. William E. Merriman, voted to take the necessary steps to the carrying-out of the request. Accordingly the church called a large council of the neighboring churches to determine upon the advisability of their action in proposing to make Mr. Noyes the foreign missionary of the church, and, if deemed wise, to ordain Mr. Noyes to that service. Of the twenty-two churches invited, two declined the invitation and two were unrepresented. Mr. Noyes made a full statement of his theological views, and answered all questions with clearness and frankness. In the private session of the council a great unanimity of feeling was manifested in regard to his fitness for the missionary service. There was no intimation of any theological unfitness. The question was in regard to the propriety of getting the case of $\mathrm{Mr}$. Noyes once more before the Board. It was agreed that Mr. Noyes should not be asked to offer himself again. 
Might it not, however, be advisable to proceed to ordain Mr. Noyes as a foreign missionary, with the understanding that the Berkeley Street Church should then, with the sanction and support of the council, endeavor to secure the recognition of Mr. Noyes as a missionary of the Board? The following resolution was passed with a single dissenting vote:

Voted - That this Council expresses its satisfaction with the examination of Mr. W. H. Noyes, and that we proceed to ordain him as a foreign missionary, and advise this church to endeavor to secure an arrangement by which he can work under the same direction as the other ministers of the Congregational Churches, and that, in case such an arrangement cannot be made, this church assume the responsibility of his direction and support.

The church at once acted upon the advice of the council, and resubmitted the case of Mr. Noyes to the Prudential Committee, but without affecting any change in the former result. In the conference with the Committee which ensued, Mr. Noyes reaffirmed the liberty of holding the "reasonable hope" which he had cherished, and the Committee reaffirmed its unwillingness, under the cautionary instructions which it had received at the annual meeting of the Board at Des Moines regarding the hypothesis of a future probation, to consider further the appointment of Mr. Noyes. At the close of the year Mr. and Mrs. Noyes were sent out as missionaries to Japan to be located in Tokyo under charge of Dr. Greene, the oldest missionary of the American Board in that country, until arrangements should be made for more permanent location. The mission was carried on for five years. It was then given over, the occasion for its separate existence having passed. At the annual meeting of the American Board, held at 
Worcester in October, 1893, the following resolution was adopted. It was significant in many ways.

Resolved, that this Board, in response to the expressed wish of its missionaries in Japan and in recognition of the successful labors of the Reverend William H. Noyes in that Empire requests the Prudential Committee to offer to him an appointment as missionary of the Board. The Board declares that this action is not to be understood as in any way modifying its former utterances on the subject of future probation.

This resolution was passed by a vote of 126 to 24 .

Still more significant were two other resolutions passed at the same meeting:

Resolved, that the limit of corporate membership be fixed at 350 (virtually doubling the membership), and that in addition to vacancies regularly occurring, 25 persons be nominated and chosen at each annual meeting for the next four years, commencing with 1894.

A previous vote had provided for nominations to the membership of the Board from the State organizations of Congregational churches - thus bringing the Board under the direct control of the churches.

A further resolution adopted at this meeting prescribed a reorganization of the Prudential Committee, reconstituting its members into three classes, the term of service of each member to terminate at the end of three years unless reëlected.

During the period between the rejection of Mr. Noyes and his final acceptance, other missionary candidates holding the same views had been rejected - or, in the phraseology of the Committee, "postponed for further light." In some instances, however, candidates like Mr. W. J. Covel, whose cases were thus postponed, refused to 
submit to further parleying and withdrew. But since the action at the Worcester meeting giving the Board over into the control of the churches, I know of no instance in which the Prudential Committee has not recognized the standards of the churches in its appointment of missionaries. Nor do I know of any instance in which it has continued to insist upon the acceptance of the dogma of a restricted Christian opportunity, despite the concluding statement of the resolution accepting Mr. Noyes, that "this action is not to be understood as in any way modifying its former utterance on the subject of future probation." And under this change of policy I can see no sign, comparing the gifts of the churches, or the offerings of the seminaries, or the quality of service rendered in the various missionary fields, with like results in former days, that the "nerve of missions" has become less sensitive to the needs of the unchristianized world or less vitally connected with the source of supply. ${ }^{1}$

1 In illustration of the change of sentiment on the part of the constituency of the Board within a little more than a decade following the Worcester meeting (1893). I quote an extract from a letter written by an official of the Board to Mrs. Tucker in acknowledgment of her hospitality during a missionary convention at Hanover. The letter bears date of December 21, 1906, and refers to the annual meeting of the Board held in New Haven in the previous October.

"I had it in mind to tell your husband of an interesting call I had from Dr. F. A. Noble, of Chicago, a short time before the annual meeting. Being under the impression that Mr. Capen was intending to retire from the presidency of the Board, he called to urge President Tucker for the position, saying we wanted to go back to the kind of president we had in Mark Hopkins. I could hardly believe my ears in view of his attitude toward the more liberal wing in the Board during the long controversy. It was most significant and beautiful."

This personal action of Dr. Noble was very generous. I do not know how completely it represented the conservative element in the constituency of the Board. It was not put to the test, as I positively declined to allow the use of my name in response to the requests which came to me from the delegates assembled at New Haven. I was then already conscious of being overburdened with college duties. I also felt that it would be unwise for the Board to recall the controversy through which it had passed, by placing in its most representative position one who had been so thoroughly identified with the controversy. 


\section{III}

Andover as a working Center during the Decade of Conflict

In passing for the time from the environment of controversy into the internal life of the Seminary, it may be difficult, perhaps impossible, to convey the impression that the essential interest at Andover was not in the controversy, but in the normal work. But such was the fact. There was an unreality about the whole contention in striking contrast with the realities of the classroom. The prosecution, as I have already remarked, was so contrary to the traditions of the Seminary and so out of harmony with the general spirit of the age, that it was hard at times to realize that it was actually going on. Most of the Faculty were graduates of the Seminary and imbued with its aggressive theological principles; and the more recent members had but just come to their duties from centers of intellectual life and activity. The enforced attention to the controversial situation compelled an interruption, at times almost a reversal of established habits of thought. But the normal interest, as I have said, centered in work, not in conflict.

The work went on under this outward disturbance without the least sense of insecurity. Perhaps there was no point at which the unreality of the controversy made itself more felt, than in the failure of the protracted litigation to awaken any fear whatever as to the final result. The action of the Visitors in deposing Professor Smyth was not taken seriously. It was impossible to believe that the action could stand. When Professor Smyth went on with his work as if nothing had taken place, his course seemed natural and consistent. These outward conditions 
created no excitement or distraction among the students. Students were not deterred by them from entering the Seminary, nor incited to leave to finish their course at other seminaries. On the contrary, there was a steady increase of students throughout the entire period. There was a notable increase in the number of mature men, some of them from other seminaries, some of them from other professions. There was a remarkable spirit of comradeship between students and faculty. This was the spirit which pervaded the classroom.

It is difficult to say whether this environment of controversy was the more annoying or stimulating; but disregarding cither view, the work of the Seminary was in itself of exceptional interest. In this respect it shared in the revived interest in theological study in all the seminaries. Subjects of special investigation in all the departments invited the most earnest attention of scholars. The revival of scholarship was nowhere more apparent than in the more advanced seminaries. Add to this general fact the local fact that the majority of the Faculty were new to their departments and obliged to construct and organize as well as teach, and it will appear that the work of each was of compelling and absorbing interest, at least to him. In nearly all of the departments it was both intensive and extensive. Theology was making severe demands upon close and accurate scholarship, and its demand was equally urgent for a wider application to the vexing problems of society. In a word, it was not chiefly the constant presence of controversy which made the work at Andover during this period of exceptional interest and concern; the work itself, for the reasons given, had an exceptional significance to those who were engaged in it. 
I confine myself, in my reference to the Andover of this time as a working center, to the work of my own department. To enter into the problems which gave interest and distinction to the work in other departments would divert me from the natural trend of these "Notes," without giving thereby any satisfactory view of the work of my colleagues.

The work of my department was twofold - the one part covering much ground already under high cultivation, the other part extending into almost entirely new territory. I must explain how this extension of the department was made, as I was responsible for it. There had been in the Seminary "from time immemorial" an unattached and somewhat perfunctory lectureship, known as the "Lectureship on Pastoral Theology." It had been assigned, from time to time, to one department or another according to some supposed fitness of the incumbent, or to the least power of resistance on his part. It seemed to me, as I looked into this lectureship, that it was capable of rendering a wide and timely service, and I therefore asked, much to the relief of my colleagues, that it might be attached to my professorship. It thus became an open door through which $I$ had free access to those social problems which were confronting the Church. It became entirely logical, under the construction put upon this lectureship, to emphasize the new and enlarged functions of the Church in modern society. And as these functions rapidly grew in importance and gained formal recognition, elective courses in sociological subjects were added under the title of "Social Economics," which after a time were given in outline in the "Review," in response to urgent demands from interested ministers and laymen. 
The chair of Preaching, to which I had been called (the Bartlet Professorship of Sacred Rhetoric), was one of the first chairs established upon the Andover Foundation. As I remarked at my inauguration, the Founders, contrary to the order of procedure in some of the earlier theological schools, at once did all in their power to insure for the truth an adequate hearing. The Trustees invariably called to the service of this department men who had had the discipline of the pulpit. The traditions of the Bartlet Professorship ran back through a line of distinguished preachers - back to Phelps, to Park, to Skinner, to Murdock, to Porter, to Griffin, the Boanerges of the Park Street pulpit, Boston. Of course each man in the succession brought to the classroom his own philosophy of preaching, the inevitable outcome of his experience, or observation, or study of the principles of his art. There were standards to be upheld by all alike, and there was a common stock of knowledge on which all must draw, but somewhere the emphasis laid on this or that requirement, showed the ruling idea which was to govern each new incumbent of the chair. My own philosophy compelled me to lay the emphasis, the strong emphasis, in preaching upon the personality of the preacher. After leaving Andover I gave the course of lectures (for 1898) upon the Lyman Beecher Foundation on Preaching at Yale. These lectures were published under the title "The Making and the Unmaking of the Preacher." "How shall we put ourselves," I asked in the opening lecture, "within so great a matter as that of preaching? Where is the point of reality? I know of no place where one may so certainly expect to find it as in the consciousness of the preacher. Around him and above him stretch the vast ranges of truth. They all con- 
tribute something to his message. Before him is the common humanity. Nothing which belongs to that can be alien to him. But neither truth nor man has anything to do with preaching until each has found the rightful place in the consciousness of the preacher" (p. 3).

And again, in asking about the true relation of the morality of preaching to the art, I said: "Preaching consists in the right correspondence between the apprehension and the expression of a given truth. The morality of preaching lies at this point, just where also its effectiveness lies. Preaching becomes unmoral, if not immoral, when the preacher allows the expression of truth to go beyond the apprehension of it. This is unreality in the pulpit. Doubtless some unreal preaching is effective, but never for long time. The law is that the power of the pulpit corresponds to the clearness and vividness of the preacher's apprehension of truth. The preacher who really believes the half truth will have more power than the preacher who half believes the truth. But it is almost equally true that preaching may fail for want of adequate expression. Hence the occasion for the art of sermonizing, or for the art of preaching; the art, that is, of making the expression of truth satisfy the apprehension of it" (pp. 62, 63).

This philosophy, or psychology of preaching, was not the substance of the classroom lectures. These lectures had to do necessarily with the technique of preaching. But this philosophy of preaching was the underlying and working principle of the department. In conjunction with Professor Churchill, a weekly or semi-weekly exercise was inaugurated at which each member of the senior class preached at least twice before the class. This exercise brought out the man as well as the sermon. Although the 
conditions were not perfect for direct and effective preaching, still it was preaching, and by the choice of subjects with some reference to the audience, it was capable of being made natural preaching. It was a far different matter from handing in a written sermon for criticism. It allowed, and called forth, criticism at all vital points. The class took the initiative, usually freely and vigorously. Not infrequently the criticism from the department came in as a corrective. Sometimes it was necessary to interpret a man to his fellows, to uncover the latent thought which had been missed by the class, to give to the preacher of the day the courage of seeing more clearly the intended and entirely possible result which he had failed to reach. At other times it was equally necessary to show a man how he was hindering the truth by some mannerism, by some insufficient interpretation, by some false note in the spiritual application. As I look back upon this exercise, I am confirmed in my philosophy of preaching - that it has to do most vitally with the personality of the preacher. I am sure that the men themselves grew in preaching power, as they grew in the understanding and use of their personality. I am sure that I came into a larger sense of their possibilities the more I studied their personal aptitudes. I think that they set themselves free very quickly from the common charge of "seminary preaching," and became preachers in their own right, their work bearing the stamp of their own personality.

The lectures, as I have said, were of necessity chiefly concerned with the technique of preaching - the formation of the homiletic habit, how distinguished from the literary or oratorical habit, how related to the philosophical and interpretative habits and to the historic spirit; 
methods of preaching, how can the so-called extempore method be cultivated to insure accuracy and precision in freedom of speech, how escape the confinement of the memoriter method, how distinguish between the method of the sermon written to be delivered, and that of the sermon written to be read; the fundamental idea of the sermon, and its great qualities of style and tone; the original sources of pulpit material, the Bible, Nature, and human nature, and secondary sources involving the consideration of plagiarism; and modern schools of preaching.

Of these general topics, I found that the greatest interest centered in methods of preaching, due in large measure to the very great difficulty of really mastering any one distinctive method. To write a sermon is not difficult, but to determine whether one shall try to put into it something of the charm of literature or something of the force of oratory, involves a study of the essential meaning of style. It is more difficult to speak without notes than to write and read or deliver, but it is far more difficult still to become a master of trained speech, so clearly a master that a man can trust himself, and that his audience can trust him. If the memory is entirely trustworthy, quick and sure in action, the memoriter sermon may be free from the unnaturalness of the method. Whenever a man was in perplexity about his method, I advised the written sermon, the sermon written to be delivered, as the basis from which one could work out his own permanent method. Doubtless a good many stick in this tentative method and never advance into the commanding forcefulness of the spoken style at its best, or into the persuasive charm of the purely written style at its best. But a period of writing is absolutely essential to most men if they are to 
gain any sure command of language. The danger of being permanently and rigidly holden to a manuscript is far less than the danger of a loose and unstudied speech, which has never passed under the severe training of the pen.

The conduct of public worship in the non-liturgical churches is so much a function of the pulpit that the subject is inseparable from that of preaching. The awakening and guidance of the spirit of devotion in the congregation virtually rests upon the minister, and like preaching, is largely determined by his personal aptitudes and training. Ineptness, or lack of the devotional sense, or want of liturgical knowledge, seriously affects the tone of the whole service, and may grievously offend the more sensitive spiritual natures. The witticism was attributed to Professor Park, returning from a winter in Boston on his retirement, that he now understood the growth of Episcopacy in the city, after hearing ministers pray. The devotional lack of the time was not altogether in the matter of public prayer. The churches suffered not a little under the reign of music committees. The order of worship often took on the character of a programme. The introduction of irrelevant music prolonged but did not enrich the service. Some fifteen minutes was added to an Easter service which one of the Andover professors had been asked to conduct, by the moralizings of a tenor soloist upon the striking of the hours - from one o'clock to twelve. Both Professor Harris and myself were frequently impressed with the need of a larger participation of the congregation in worship, not through a lowering but through an elevation of the standard of congregational singing. The experiment of utilizing the congregation 
under the leadership of a large and highly trained choir had been tried with assuring success at the Central Church, Providence, during the pastorate of Professor Harris, and under the direction of Mr. Glezen as organist. I had been much impressed by the service at this church, as I was often called to supply the pulpit. Taking this experiment as a practical suggestion, we set at work with the coöperation of Mr. Glezen upon the preparation of a hymn book which might be a stimulus to worship. The now familiar tunes of the best English composers had not then come into general use, and the hymn books were scant of hymns expressive of the experience of the modern Christian. The old hymns and tunes of enduring quality were retained, but the number of hymns usually found in a compilation twelve to fourteen hundred - was reduced to seven hundred and fifty-nine, and in the popular edition of the book to four hundred and eighty-nine. The Psalms were arranged for chanting as well as for responsive reading. The title of the book was, I think, the best that has been adopted - "Hymns of the Faith." It has its special fitness in the fact that the arrangement was based upon, and followed the order of the Apostles' Creed.

The preparation of the book was to us both a refreshing labor. Professor Harris wrote from his summer home in Bar Harbor, "Strange as it may seem" (the controversy was well under way) "the hymn book is now on my mind more than any other project." The reception accorded to the book was both gratifying and amusing. Where, however, it was amusing to the editors, it was perplexing to the publishers. Houghton, Mifflin \& Company had had some experience in the somewhat analogous sale of textbooks, but I doubt if they ever found the hobbies of school- 
masters and school committees quite so vexing as the whims of churches. Some hymn had been left out - probably excluded; could not a new edition be prepared to include it? Here and there a new adaptation of tune to hymn had been made - not allowable. Like the book, but type too small for one of our members - that settles it. Too many new tunes, takes too much time to learn them. Many of the criticisms were valuable, and on the whole the response was quicker and more general than we had anticipated. Occasionally a letter came in, like this from Professor Sewall, of Bangor, from which I quote.

Last evening went all thro' it - like a Chinaman beginning at the end and working back to the beginning - and I want to tell you that I like it thoroughly, from end to end, whicherer end you start with. It is good - full of good hymns, and full of good music. It strikes me with admiration that you have been able to keep out so much that must have clamored for admission; and further that you have put into so small compass so much that is highest in taste and sweetest in music. Only - if you ever issue another "popular edition," do, do, do leave out that rascally Greenville! - which I think must have been about worn out by the time the fellow got it done. I hope I may meet brother Rousseau in heaven - i.e., if he gets there - and provided I get there too - which ifs you may set down as a pair of twins; but if he does get there, I am sure his tune will have been burnt off of him in the fires of purgatory thro' which he will have to pass. But those other tunes - of Monk and Dykes and Stainer and Barmby and Tours et al. - just lift one's soul up into heaven.... I hope those composers will go into the heavenly life with their creative powers all perfect, and forever increasing.

"Hymns of the Faith" soon took its place as an educating force in hymnology, popularizing the best tunes, 
and helping to put the right valuation on hymns. The fact is often overlooked that it is as much one of the religious functions of every generation to winnow its hymns as to revise its creeds.

The Lectureship on Pastoral Theology, which was used chiefly to relate the Church to its new social duties, required a certain amount of attention to satisfy its original demands. The pastoral offices were treated altogether by lectures; the administration of the local church also by lectures, but still more definitely in connection with a system of scholarships, which gave the students access to the working of thoroughly organized churches. Berkeley Temple, which had become an institutional church under the pastorate of Dr. Charles A. Dickinson, gave employment on Saturdays and Sundays to a considerable number; others spent an equal amount of time in the service of churches in the neighboring manufacturing towns; others still devoted a certain amount of time on Sundays or during the week in work at the Concord Reformatory, or in other reformatory institutions in eastern Massachusetts. Berkeley Temple especially became the headquarters for students engaged in this diversified service. Friends of the Seminary, in coöperation with the church, made over an unused loft in the church building into dormitories, which afforded ample and attractive accommodations for the greater part of the holders of these scholarships in Pastoral Theology whose work was in Boston.

I insert the following schedule of lectures in Homiletics and Pastoral Theology to indicate the ground covered in the prescribed work of the department: 


\author{
Scheme of Lectures \\ IN \\ Homiletics and Pastoral Theology
}

I

PREACHING

1. The Homiletic Habit

How related to -

1. The Oratorical Habit

2. The Literary Habit

3. The Art of Interpretation

4. The Dogmatic Method

5. The Historic Spirit and Method

6. The Homiletic Habit defined

2. Methods of Preaching

1. The Extempore Method - qualifications, training, dangers, safeguards

2. The Memoriter Method

3. The Method of the Sermon written to be delivered

4. The Method of the Sermon written to be read

3. The Making of the Sermon

1. The Fundamental Idea of the Sermon

2. Varieties of the Sermon

The Textual, the Topical, the Serial

3. The Sermon in Structure

Text - Introduction - Development - Conclusion

4. The Sermon in Style

Vitality - Sincerity - Plainness - Force -

Beauty

The Formation of Style for the Pulpit

5. The Sermon in Tone

4. The Sources of Pulpit Material

Original Sources

1. The Bible - considered as the Preacher's Book

2. Nature 
3. Human Nature - the study of men

4. The Christian Experience

Secondary Sources - involving the consideration of plagiarism

5. Supplementary Topic: Modern Schools of Preaching

\section{II}

- THE CONDUCT OF PUBLIC WORSHIP

1. The Present Revival of Worship in the Non-liturgical Churches

2. Qualifications on the part of the Ministry for the Conduct of Public Worship

3. The Service of the Sanctuary with Reference to the Order and Proportion of Parts

4. The Use of Scripture, Liturgic and Didactic

5. Hymnology and Church Music

6. Public Prayer

7. The Administration of the Sacraments

\section{III}

PASTORAL THEOLOGY

1. The Pastoral Offices

1. The Cure of Souls

2. The Bringing of Men to Christ

3. Training in Character

4. Social Visitation

5. Visitation of the Sick

6. The Offices of Consolation

7. The Burial of the Dead

2. The Administration of the Church

1. The Church in Idea and Purpose

2. Membership in the Church

3. The Local Church in its Organization - a working force in a community

4. The Teaching Capacity of the Church - the Sunday School 
5. The Church in its Benevolence - Charities and Missions

6. The Church in the Expression of its Spiritual Life devotional meetings

7. The Church in its relation to the Indifferent and Prejudiced Classes

The venture of the department into the field of sociological studies was an innovation in a theological school. Few colleges had then entered the field; there was lack of a proper scientific background for the more practical professional uses of the new science. But nowhere was there greater need of the right understanding of the changjng social conditions, than among those who were concerned with the social instrumentalities and agencies of the Church. The Church, in the absence of any really scientific study, was already active in the field of philanthropy, and in some localities was intensifying its unscientific activities. There was a growing suspicion among careful investigators and students that the Church was going wrong in its efforts, and that it was in danger of becoming obstructive to the progress of the new social order. The impulse actuating the Church was charity, and its chief agency was the charitable organization of some form, most frequently associated with the mission. Some of the evils of the methods employed, manifest in the pauperizing of families and communities, had been or were being corrected by more careful and comprehensive organization. The organization of Associated Charities accomplished much in the prevention of waste and of the demoralization incident to it. But the fundamental idea was still that of charity, and the whole trend of events was showing the insufficiency of the idea for social reform and advance. The greatest social grievance came from those 
who, if in need of charity, did not want it - the vast army of unskilled labor. Their grievance, as it became understood, changed the whole problem from that of charity to that of economic justice. In like manner a change was going on in the theory of treating the defective and otherwise dependent classes - not the more abundant relief of the deficient and dependent, but the prevention so far as possible of deficiency and dependency.

It seemed imperative that the incoming ministry should be apprized of these changes, and as few had been so apprized in their academic training, that the Seminary course should be open to the necessary instruction, even if mainly corrective and directive. This was the reason and the intent of the elective courses in Social Economics. The title was chosen to emphasize the fact that if "theology [was] to be applied to life" under modern social conditions, it must be applied in terms which could be understood. Social economy had a definite relation to the Church, after the analogy of the relation of political economy to the State. The separation between Church and State has no correspondence in any like separation of Church and society. The Church has social obligations, duties, and even functions, emphasized by the absence of like political functions. This social obligation of the Church had been recognized in many ways, but the obligation began to assume a new meaning and far greater proportions as modern society had to take account of industrialism which created new conditions and new classes. The whole social economy was modified especially in ways most disturbing to the social influence of the Church. The study of the enlarged and more complicated social economy was thus necessary if the Church was to 
maintain or recover its influence. The introduction of "Social Economics" into the Seminary curriculum apprized the churches of the times upon which they had fallen.

I was not at all surprised at the readiness of my colleagues to make a place for the courses in social economics among the new electives offered; but I was surprised to find how quickly the idea found acceptance in the churches. When it became generally known that such courses were being given in the Seminary, the desire was expressed by many ministers and laymen that they be also offered as Seminary extension courses. It was impossible to comply in a satisfactory way with the requests received, owing to the labor required, chiefly of correspondence, in carrying on extension courses, and also owing to the lack of reference libraries furnished with the necessary authorities.

But an arrangment was made through the "Review," by which three yearly courses, more general in their character than those of the classroom, were outlined in monthly parts, with reference to such authorities as could be found in most public libraries. The idea running through these courses was that of the new obligations which society was assuming (under the incoming social order), toward those who had received scant recognition or insufficient treatment as members of society. Broadly classified such were, (1) those who represented the demands of labor for a larger social hospitality; (2) those who through poverty and disease had lost social standing; (3) those who through crimes of various degrees had forfeited their rights in society. These classes were asking in one way or another for a rehearing of their case. The coming question was not the familiar question of the 
protection of society and its interests, but the question of how to bring the untrained, the disheartened, the dangerous classes into normal relation to society. I give the course for the year 1889 in outline as an illustration of the object and method of each course. It was the object of this course to give a sympathetic approach to the study of the labor movement through the proper historic perspective.

\section{Subject \\ The Soctal Evolution of Labor}

Topics

1. The Transition from Slavery to Serfdom

2. The Workman of the Free Cities

3. The English Laborer at the Rise of Industrialism

4. The Factory System

5. Chartism and Trade Unionism

6. English Labor Legislation

7. The Political Relation of Democracy to the Laboring Classes

8. Labor in the United States as affected by Slavery and Immigration

9. Labor in the United States as affected by State Systems of Education

10. Wages and Profits

11. What constitutes a Working Day: the Use of Leisure

12. Socialism in the United States compared with Socialism in Germany and England

References were given in practicable detail under each topic. I had occasion to know that frequent requests were made at the public libraries for the purchase of the less known among the authorities named, and that now and then a reading club began the collection of books and reports bearing upon the subjects under discussion. 


\section{SUBJECT FOR 1890}

The Treatment of Crime and the Criminal Classes.

(The Relation of Society to those who have forfeited their rights in it)

\section{SUBJECT FOR 1891}

The Treatment of Pauperism and Disease.

(The Relation of Society to those who through various disabilities are unable to keep their place in it)

I append a few extracts from letters, chiefly of inquiry, to show the nature and extent of the interest in the subjects brought under discussion.

From Wellesley:

I wish to express my great obligation to you for the "Outlines in Social Economics" brought out in the "Andover Review." Section I has suggested and in part furnished the basis for our work in Economics for this winter term. It has proven to be just what we needed to lead up to the study of schemes of industrial reorganization.

From Brown University - Department of Political and Social Science:

Will you kindly inform me as to whether the papers upon "Social Economics" which you have written for the "Andover Review" have appeared in any other form? If so, are they to be had for class study, and how may they be procured?

From the Principal of Bradford Academy:

I belong to a club of Bradford and Haverhill ladies who are taking up this subject, following your plan, by my suggestion. And we hope to have some public meetings in Haverhill this winter, at one of which the ladies are very desirous to have the pleasure and profit of an address from you. We think we may get a company of manufacturers and perhaps employees. And we hope it may set some people to thinking. 
Pastor of church in Topeka, Kansas:

I am growing more and more interested in the sociological problem. I am coming to believe that the second service of the church should be directed towards this line of work, and I have a church here that is ready to follow in this departure from the old traditional conception of what constitutes proper church work. It is very plain to me that the church must in some very strong way face the question of the hour, or else acknowledge that when Christ spoke of the Life more abundantly he did not mean the existence we have to live on the earth.

From a lawyer in Marietta, Ohio:

Will you please inform me whether or not you have published in pamphlet or book form your excellent papers on "Social Economics"? I hope to see all you have published on that subject, especially on "The Treatment of Crime and of the Criminal."

From a firm of young Boston lawyers, since well known for their interest in social questions, who were organizing a class in the Social Science Institute:

If your work were in an accessible form we should make constant use of it.... If publication in separate form is contemplated, we shall plan with a view to making this the guide for most of our study. Our prospects seem now fair. It is difficult to popularize serious, scholarly research.

From a California clergyman:

A number of the topics treated in your course of "Social Economics" we desire to study in our Ministerial Association. Our plan is, to lay out a course of study for the year, giving authorities on the subjects selected and indicating a course of reading along parallel lines. It would be of great assistance to us if we could obtain in advance references to books and documents on sections II and III.

Two schemes for solving the social problem at points where it was most acute were at this time before the public. 
They differed widely, but each required careful attention. One of them called for a critical examination of the principles on which it rested; the other invited personal investigation to determine its practicability.

In June and December, 1889, Mr. Andrew Carnegie published two articles in the "North American Review" under the titles, "Wealth," and "The Best Fields of Philanthropy," which at the instance of Mr. Gladstone were reprinted in the "Pall Mall Gazette" under the more striking title, "The Gospel of Wealth." This, however, was the term in which Mr. Carnegie had announced his belief in the efficacy of his scheme, "Such in my opinion is the true gospel concerning wealth, obedience to which is destined some day to solve the problem of the rich and the poor, and to bring 'peace on earth, among men good will.' " In explanation of the practical working of this "Gospel" he went on to say:

We start with a condition of affairs [referring to the competitive system] under which the best interests of the race are promoted, but which inevitably gives wealth to the few. Thus accepting conditions as they are, the situation can be surveyed and pronounced good. The question then arises - and if the foregoing be correct it is the only question with which we have to deal - What is the proper mode of administering wealth after the laws upon which civilization is founded have thrown it into the hands of the few? And it is of this great question that I believe I offer the true solution. It will be understood that fortunes are here spoken of, not moderate sums saved by many years of effort, the returns from which are required for the comfortable maintenance and education of families. This is not wealth, but only competence, which it should be the aim of all to acquire, and which it is for the best interests of society should be acquired.

There are but three modes in which surplus wealth can be 
disposed of. It can be left to the families of the decedents; or it can be bequeathed for public purposes; or, finally, it can be administered by its possessors during their lives. . . .

Thus is the problem of rich and poor to be solved: the laws of accumulation will be left free; the laws of distribution free. Individualism will continue, but the millionaire will be but a trustee for the poor; intrusted for a season with a great part of the increased wealth of the community, but administering it for the community far better than it could or would have done for itself.

If Mr. Carnegie had simply made public use of his own method of beneficence or philanthropy as an example of what he conceived to be the true relation of private wealth to society, even if it had been in the way of a certain self-exploitation, his announcement would have awakened much interest and could not have fairly subjected him to criticism. As it was, it received the uncritical endorsement of Mr. Gladstone, Cardinal Manning, and many others. The public at large was delighted with the aphorism, "it should be a disgrace for a man to die rich," and heartily accepted his statements about the curse of wealth as a family inheritance. There was a dramatic interest attending the struggle of this modern Laocoön to keep himself and his family from being strangled in the coils of his enormous income. Here was a man who was not hoarding his riches, or flaunting them in demoralizing luxuries. Here, too, was a man whose business career, judged by the standards of the time, had been beneficent, due allowance being made for the fact that he himself had been made to a questionable degree a beneficiary of the Government through the operation of an excessive tariff, of which he had taken advantage. And here was a man who was endeavoring to carry over his business principles and methods into his benefactions. 
Mr. Carnegie was entitled to the credit of all these considerations and others of a more personal nature at the hands of his critics. Fair criticism began with the theory of the relation of private wealth to society, which Mr. Carnegie put out as a gospel. When this gospel was critically examined it was found to rest upon two postulates first, "we start with a condition of affairs [referring to the then existing economic system] under which the best interests of the race are promoted, but which inevitably gives wealth to the few"; and second, "the millionaire will be but a trustee for the poor, intrusted for a season with a great part of the increased wealth of the community, but administering it for the community far better than it could or would have done for itself." A gospel of wealth, embodying these principles could have no part in that social reconstruction which was to insure a fairer distribution of wealth, and to impose upon society itself the responsibility for its public uses. The publication of this "gospel," with the interest attending the personal application of it, brought the discussion of the whole social economy to a clear and sharp issue. It gave a new meaning to the discussions of the classroom, and to those public discussions in the press and on the platform which had to do with the principles and methods of the new social order. The position taken in the Andover classroom, and from time to time in public, is set forth in an article in the June number, 1891, of the "Andover Review" under the title "The Gospel of Wealth."

In contrast with the scheme for social betterment set forth in the "Gospel of Wealth," a social experiment had been going on for some little time in one of the slums of London (the Stepney district of East London), where a 
group of university men from Oxford had "gone into residence" in the neighborhood to identify themselves with its people and its interests. This group constituted the university or social settlement known as Toynbec Hall. The striking originality of the settlement idea lay in its perfect simplicity. It departed as far as possible from the institutional idea and methods, and laid the emphasis altogether upon the use of personality. Its aim was the identification of the residents with their neighbors first to know them and their conditions, then to create a neighborhood consciousness, and then to initiate and encourage methods for mutual service in behalf of the neighborhood. The scheme was singularly free from all questionable results in principle or theory, but was it practicable? And if practicable in London could it be adjusted to social conditions in New York, Chicago, and Boston? Fortunately for the Seminary in its purpose to make a careful investigation of the working of the Settlement idea, an arrangement was made with Mr. Robert $\mathbf{A}$. Woods, then a member of the advanced class and specializing in social economics, to become a resident at Toynbee Hall. He spent the greater part of the year 1890 in residence, and on his return gave a course of lectures at the Seminary embodying the results of his studies and experiences, which were soon published by Charles Scribner's Sons under the title of "English Social Movements" the first book on this subject from the American point of view. The outcome of this investigation of the working of the settlement idea through the residence of Mr. Woods at Toynbee Hall, was the establishment of the Andover House in Boston with Mr. Woods as Head of the House.

The story of the organization and early development 
of the Andover House, including the exposition of its aims as then put before the public, is told in a series of printed circulars issued at the time and on file at the South End House. The record of the "House" since its establishment is to be found in the annual reports. On the occasion of the twenty-fifth anniversary of its founding, I prepared an article for the "Atlantic Monthly" (May, 1917), under the title "Twenty-five Years in Residence," which gave a succinct account of the growth of the social settlements throughout the country within that period. From this article $I$ quote in part the specific reference to the Andover House, known since $\mathbf{1 8 9 5}$ as the South End House, but unchanged in its object or general management. The "House," from the beginning until now, has been a constant witness to the insight, the breadth of view, the courage and the loyalty to the "idea" which have characterized the remarkable leadership of $\mathrm{Mr}$. Woods; qualities which have given him also his influence in public affairs.

Although the twenty-fifth anniversary of the South End House, Boston, was the occasion, not the subject, of this article, a closing word of reference is due to the "House" as being in itself one of the most complete and consistent illustrations of the settlement idea. Forced by the needs of the neighborhood to take on a considerable institutional development, it has in no wise departed from the original residential type. This consistency of development has been secured by maintaining an unusually large residential force, and by scattering its working agencies throughout the district instead of concentrating them at one locality. There are in the settlement to-day thirty-two residents, twelve men and twenty women. Among these are five married couples having their own homes, two in apartments provided at the "House," three at different points in the neighborhood. Nine of the residents are on salaries for full time 
and three for part time; four are holders of fellowships; the remainder are unpaid, five of whom devote their entire time to the work. To the residents are to be added over one hundred associate workers, a number of whom are from the neighborhood. The whole force is under the direction of a staff of six of the most experienced workers. One fourth of the residents have been in service for over four years. Mr. Woods has been the head of the "House" from the beginning, the only instance, except that of Miss Addams, of like continuous service. The exceptional permanency of the residential force has given special value to the social and economic investigations of the "House."

An interesting experiment was carried out at the time in applying the group system to pastoral work in rural communities. Five men of the class of 1892 at Andover Seminary - W. W. Ranney, Oliver D. Sewall, James C. Gregory, Edward R. Stearns, and Edwin R. Smith joined together in a group for associated work in neighboring churches in a section of Maine lying for the most part between Farmington and the Rangeley Lakes. They gave over for a term of years the home life of a parsonage, and relied for their social stimulus upon close relation with one another so far as local conditions would permit. The churches allowed frequent interchange of service, and the community interests were so much alike that the same plans for the development of the communities were applicable to all. It was not social settlement work. The churches as such were the essential concern. The question of the sects had to be considered, though the spirit of union was uppermost in most instances. The individuality of the man of the country above that of the dweller in the city was very much in evidence. But the experiment, largely directed and aided by President Hyde, of Bowdoin, was successful beyond even the expectations 
it had raised, and the experience gained by members of the group was of much suggestive and stimulating value in their later and more permanent pastorates. The work of the "Maine Band" was an object lesson in the possibilities of the group method in its application to the more remote and difficult rural fields.

I should not wish to convey the impression that the exceptional took precedence over the regular, or even the conventional, in the conduct of the Department. Certain things were done outside the ordinary routine, because there was a call for change of methods of work as well as a call for changes in the statement of truth. But preaching was preaching, and pastoral service was pastoral service under all changes; and the supreme object of the Seminary was the same that it had been from the beginning. And what was true of my department was true of all the departments. Any one going over the courses of study outlined in the catalogues of the period will be surprised to see their variety and extent. The prescribed courses were supplemented in all the departments by "optional" and "elective" courses. A fourth year for advanced study was inaugurated and much valued by many graduates. But through all the advances and extensions ran the broad but straight course of a theological discipline.

The fact wlich I have wished to make clear in this glimpse of the internal life of the Seminary during the period of conflict is this - the work was of first interest, the conflict of secondary interest. The conflict did not hinder the work. It did not deter many students from coming to Andover or distract them when once there. The attack upon Andover began in the spring of 1882, in ample time to affect the class entering the Seminary in 
the fall of that year. The class which then entered graduated in 1885. Reckoning onward from that date, the Seminary graduated in the decade following - the decade of controversy - one hundred and fifty-seven men, taking no account of students in the "Advanced Class," some of whom were always from other seminaries. Reckoning backward from the same date (1885), the Seminary graduated in the decade preceding the controversy, one hundred and eighty-four men. Measured numerically the cost of the conflict in men was negligible. Measured in terms of quickened and extended interest, it left a balance of gain to the Seminary. As I have followed the graduates of those years into their professional careers, and have taken account of their standing and influence in the pulpit, in theological and academic chairs, in positions of executive authority, and in the more advanced forms of social service, I am impressed with the substantial and enduring qualities of intellectual and spiritual power developed in the stormy period of their theological training.

\section{IV}

The Andover Trial and Its Results

Early in July, 1886, each of the five professors associated in the conduct of the "Andover Review" and joint editors of "Progressive Orthodoxy," received the following communication:

Copy from record of meeting of Board of Visitors at Boston, July 7th, 1886, in respect to notice of Charges to be made against Professors in Andover Theol. Seminary.

It was voted - that the Secretary be empowered to receive the charges, when specified and signed by these reverend gentlemen, and be instructed to notify the parties, against whom the charges are made, of the filing of the same, and furnish a copy 
thereof, and that they may respectively appear and file an answer within fifteen days of the notice, after which a meeting shall be held at the call of the President, to hear and consider the proofs and answers to said charges from the complainants and respondents, of which meeting all parties shall have due notice.

A true copy of record.

W. T. Eustis, Secy.

A second communication from Dr. Eustis, dated Springfield, Massachusetts, July 27, was received, forwarding a copy of the charges filed with the Board of Visitors. As these charges formed the basis of the trial which followed, they are given in full; also the reply of the professors made within the specified time.

To the Reverend and Honorable, the Board of Visitors of the Theological Seminary at Andover:

Gentlemen: The undersigned - understanding that the Additional and Associate Statutes of the Seminary (Art. X, XX) require your Honorable Body to take care that the duties of every Professor in the Institution be intelligibly and faithfully discharged, and that you admonish or remove him either for misbehavior, heterodoxy, incapacity, or neglect of duty; recognizing, therefore, the duty and power of the Visitors to act in these respects either with or without suggestions from other parties; and, from a decision of your Honorable Body of date 5 September, 1844, inferring that it is regarded as immaterial in what way any state of things which may call for interposition may come to their notice - did, on 6 July current, address your Honorable Body, asking leave to present at that time a series of statements which should illustrate and establish the fact that certain Professors now active in the Seminary hold and teach, there and elsewhere, doctrines not in accordance with its Foundation, and therefore - to use the language of the Act, which, 17 January 1824, incorporated the Board of Visitors - not "according to the terms and conditions prescribed by 
the Statutes of the Founders thereof, agreeably to the intentions of the Founders."

Our purpose was not to table formal charges against our friends the Professors; because we conceived that it might be a more regular course for the Visitors, on coming to the knowledge of an existing necessity, themselves to enter upon an investigation of the alleged facts, in such manner as should seem to them wisest and most expedient.

Your Honorable Body were, however, pleased to suggest, that in the present instance, a different course would better meet your views, and desired us to formulate the substance of what we felt it to be our duty to urge, in propositions which may in advance be furnished to those to whom they refer. While aware that it is made the special responsibility of the Visitors, of their own personal movement, to be on the alert to observe departures from the true intent of the Founders of the Seminary, and to initiate measures to avoid such departures; we consent in any way within our power to further the object which they and we may well be supposed to have in common; and with this explanation we cheerfully comply with that request, and proceed hereinafter to designate certain points as among those in regard to which we apprehend that the five Professors who edit the "Andover Review," through utterances in the said "Review," in the book called "Progressive Orthodoxy," and in their instructions in the Lecture room - no longer continue to approve themselves men of sound and Orthodox principles in Divinity agreeably to the Creed, which they have made and subscribed a solemn declaration that they believe, and to which they have promised religiously to conform.

From a sense of duty, therefore, we are constrained to bring before your Honorable Body, complaints against the following Professors in the Theological Seminary at Andover, to wit: Rev. Egbert C. Smyth, D.D., Brown Professor of Ecclesiastical History; Rev. William J. Tucker, D.D., Bartlet Professor of Sacred Rhetoric; Rev. J. W. Churchill, M.A., Jones Professor of Elocution; Rev. George Harris, D.D., Abbot Professor of Christian Theology; and Rev. E. Y. Hincks, D.D., Smith Professor of Biblical Theology. 
I. First, we charge that the above-named gentlemen, to wit: Professors Smyth, Tucker, Churchill, Harris, and Hincks, hold beliefs, have taught doctrines and theories, and have done other things as hereinafter enumerated, which are not in harmony with, but antagonistic to, the Constitution and Statutes of the Seminary, and "the true intention" of its Founders, as expressed in those Statutes.

II. Secondly, we charge that the above-named Professors, contrary to the requirements of Articles XI and XII of the Constitution, as modified by Article I of the Additional Statutes, are not men "of sound and Orthodox principles in Divinity according to" "the fundamental and distinguishing doctrines of the Gospel of Christ as summarily expressed in the Westminster Assembly's Shorter Catechism .... and as more particularly expressed in the following Creed," to wit, the Creed of the Seminary; but that, on the other hand, they believe and teach in several particulars, hereinafter enumerated, what is antagonistic to the Seminary Creed, and, therefore, in violation of the Statutory requirements of the Founders.

III. Thirdly, we charge that two of the above-mentioned gentlemen, viz., Professors Smyth and Tucker, in breach of the requirement of Art. II of the Associate Foundation upon which they are placed, are not "Orthodox and Consistent Calvinists," but on the other hand, believe and teach, in several particulars, hereinafter enumerated, what is opposed to the Seminary Creed, - the Creed in which the donors of the Associate Foundation put fully and clearly on record their conception of "Orthodox and Consistent" Calvinism.

IV. Fourthly, we charge that the several particulars of the "heterodoxy" of all the above-mentioned Professors, and of their opposition to the Creed of the Seminary, and to the "true intention" of the Founders as expressed in their Statutes - for any or all of which particulars of heterodoxy, and opposition, if proven, the Board of Visitors is required, by Articles $\mathrm{X}$ of the Additional Statutes and XX of the Associate Foundation, to "admonish or remove" them - are as follows, to wit: They hold, "maintain and incelcate": 


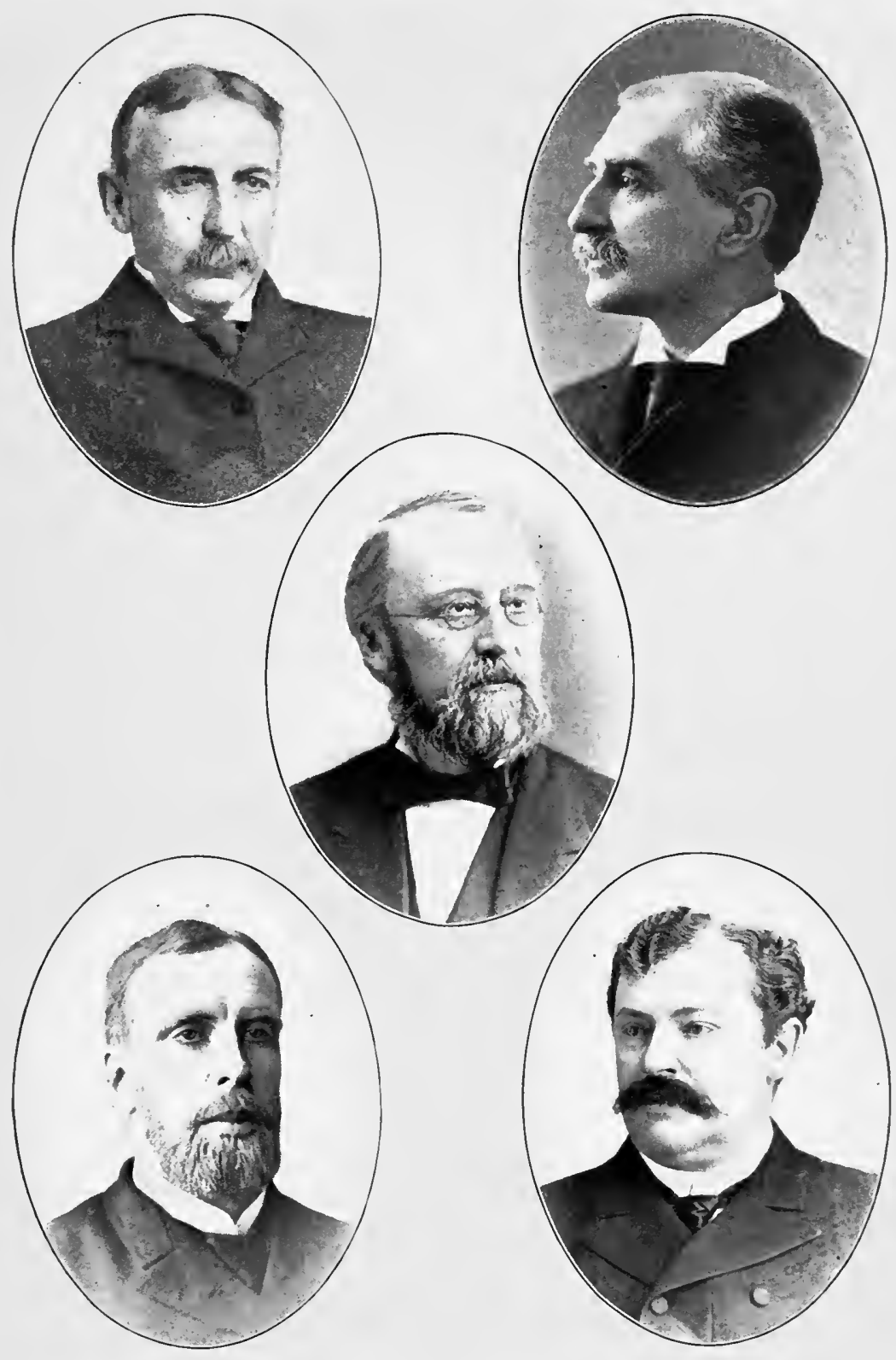

THE DEFENDANTS IN THE ANDOVER TRIAL

George Harris

Edward Y. Hincks
Egbert C. Smyth

William J. Tucker John W. Churchill 

1. That the Bible is not the only perfect rule of faith and practice, but is fallible and untrustworthy even in some of its religious teachings.

2. That Christ, in the days of His humiliation, was merely a finite being - limited in all His attributes, capacities, and attainments.

3. That no man has power, or capacity, to repent, without knowledge of the historic Christ.

4. That mankind, save as instructed in a knowledge of the historic Christ, are not sinners, or if they are, not of such sinfulness as to be in danger of being lost.

5. That no man can be lost without having had knowledge of Christ.

6. That the Atonement of Christ consists essentially and chiefly in His becoming identified with the human race through His Incarnation; in order that, by His union with men, $\mathrm{He}$ might endow them with the power to repent, and thus impart to them an augmented value in the view of God, and so propitiate God to men, and men to God.

7. That the Trinity is modal, and not personal.

8. That the work of the Holy Spirit is mainly limited to natural methods, and within historic Christianity.

9. That without the knowledge of the historic Christ, men do not deserve the punishment of the law, and that therefore their salvation is not "wholly of grace."

10. That faith ought to be scientific and rational, rather than Scriptural.

11. That there is and will be probation after death, for all men who have not in this world had knowledge of the historic Christ.

12. That this hypothetical belief in probation after death should be brought to the front, exalted, and made central in theology, and in the beliefs of men.

13. That Christian missions are not to be supported and conducted on the ground that men who know not Christ are in danger of perishing forever, and must perish forever unless saved in this life.

14. That a system of physical and metaphysical philosophy is 
true which by fair inference neutralizes the Christian doctrine as taught in the Creed of the Seminary.

15. That there is a "New Theology better than the Old"; which we apprehend is not in harmony with the Creed, but fatally opposed to the same.

16. That the said Professors hold and teach many things which cannot be reconciled with that Orthodox and consistent Calvinism which the Statutes require of them, and to which they stand publicly committed; and that in repeated instances these Professors have broken solemn promises made when they subscribed the Creed.

The undersigned are ready to appear before your Honorable Body, at your early convenience, and sustain by specifications and proofs the apprehensions and allegations above recounted, further asking leave - and giving hereby to our friends the Professors notice that it is our purpose - additionally to set forth:

That the pleas publicly made by them in justification of these departures from the Statutes of the Seminary are invalid; and

That there exists in the religious community a widespread and positive judgment, that the teachings to which we have referred are scandalously inconsistent with any honest and hearty acceptance of the Creed; which judgment, for the good name of the Seminary, the honor of Evangelical religion, and the honest administration of trust funds given by devout and generous donors for specific purposes, requires immediate and grave consideration.

Supplicating the God of Truth and Holiness to guide your Honorable Body, our friends the Professors, and ourselves, in all this painful business as shall most advantage His cause, we subscribe ourselves

Faithfully yours

\section{J. W. WeLlian}
H. M. Dexter
A Trustee of the Seminary.
O. T. LANPHEAR
J. J. Blaisdell

Committee of certain of the Alumni

Boston, Mass.

23 July, 1886 
Joint reply of the Professors, each under his own name:

To Rev. W. T. Eustis, D.D., Secretary of the Board of Visitors of Andover Theological Seminary.

DEAR Sir, - I have received from you under date of July 27, 1886, a copy of the vote of the Board of Visitors passed at a meeting of the Board held in Boston, July 7, 1886, and which reads as follows: "It was voted that the Secretary be empowered to receive the charges when specified and signed by these reverend gentlemen, and be instructed to notify the parties, against whom the charges are made, of the filing of the same, and furnish a copy thereof, and that they may respectively appear and file an answer within fifteen days of the notice, after which a meeting shall be held, at the call of the President, to hear and consider the proofs and answers to said charges from the complainants and respondents, of which meeting all parties shall have due notice." I have also received from you a printed copy of charges and specifications filed against Egbert C. Smyth, William J. Tucker, J. W. Churchill, George Harris, and E. Y. Hincks, by J. W. Wellman, a Trustee of the Seminary, and Henry M. Dexter, O. T. Lanphear, and J. J. Blaisdell, a Committee of certain Alumni whose names are not given. This copy is dated Boston, Mass., July 23, 1886.

From introductory statements in the letter of the reverend gentlemen we learn that they addressed you, July 6, asking leave to present at that time a series of statements (here followed a quotation concerning that which they intended to show), that their purpose was to incite you to inquire into our alleged nonconformity to the requirements of the constitution and creed of the Seminary, that instead of yourselves initiating the investigation thus requested you suggested to them to formulate what they felt it to be their duty to urge.

I am perfectly willing now, and at all times, as in duty bound, to acquaint your honorable body with whatever pertains to my teaching and conduct as a Professor in Andover Theological Seminary. For your information solely, I now make answer frankly but briefly, as suited to the present situation, to the 
printed charges and specifications. This reply is not of the nature of a defense, but simply expresses my sense of the truth or pertinence of said charges and specifications, but I an ready, if desired, upon sufficient notice, to vindicate myself against them. I now simply define my general relation to their matter or contents.

In making these replies I do not concede the right of the reverend gentlemen who sign the charges to appear against me before the Visitors. I take exception to their competence as prosecutors, and hereby reserve all rights involved in taking such exception. I also reserve all other rights which relate to mode of procedure, and which attach to any legal aspects of the case which are or may be involved.

To charges I, II, and III, and those portions of IV designated as 14,15 , and 16 , being of a general or indefinite character, $I$ answer by a general denial. I further answer to the remaining specifications under IV as follows:-

(1.) I deny the allegation.

(2.) I deny the allegation.

(3.) I deny the allegation.

(4.) I deny the allegation, teaching that all men are sinners and are already lost until saved by Christ.

(5.) The statement is ambiguous. If it means that man left to himself is not under condemnation, I deny the allegation. If it means that in view of God's gracious revelation in Christ no man will be hopelessly and eternally lost who has not had knowledge of Christ, I admit I hold such an opinion as having a high degree of probability, and maintain that it is not excluded by the Creed.

(6.) I hold a view substantially like this as being an important but not the chief part of the truth of the Atonement.

(7.) I hold and teach precisely the opposite view, that the Trinity of Divine Being is personal or ontological, and not modal or economical.

(8.) I hold that the work of the Holy Spirit is supernatural and chiefly under the conditions of truth and motive supplied by the gospel.

(9.) See answers to 4 and 5 .

(10.) I hold that if faith is Scriptural it will be scientific and 


\section{THE ANDOVER PERIOD}

rational, and vice versa, but I do not fancy the term scientific as applied to faith.

(11.) I do not employ the phrase "the historic Christ" as equivalent to the "gospel." My belief in the universality of Atonement which is affirmed in the Creed, yields as a natural corollary the belief that all men will have knowledge of God in Christ.

(12.) I do not so hold nor teach. No one could hold that a hypothetical belief could be central in theology and in the belief of men.

(13.) I recognize the danger of men and their lost estate without Christ as motives to preach the gospel to them, but not the only motives. Punishment is not the chief motive power of the gospel.

All of which is respectfully submitted.

[Signed by each and all of the accused Professors.]

Upon the same day on which the answer to the charges was received by Dr. Eustis, he wrote in behalf of the Visitors to Professor Egbert C. Smyth inquiring whether, in place of the proposed meeting of the Board with the complainants and the defendants, "if the allegations of the complainants ... in support of their charges should be presented in writing," the professors would make answer in the same way. In forwarding this proposal to his colleagues, who were then widely scattered during the vacation, Professor Smyth expressed himself as strongly opposed. "I prefer," he said, "something very different. If the trial is to go on it seems to me now that it ought to be public and at Andover, where the library and our authorities are. We have been maligned from Dan to Beersheba. Let our accusers now face the music. Hold them to every specification and the Visitors to a verdict on each. ... If any trial is had I go for thoroughness." In this sentiment all the accused professors heartily concurred and unanimously declined the proposal of the Visitors. 
Whether this declination led the complainants to ask leave to make certain changes in the form of their complaint, or whether these changes were made by direct order of the Visitors is not known. But on November 8 a document entitled "Amended Complaint" was sent to each of the accused professors by the secretary of the Board, according to which further proceedings were to take place. The copy sent to me follows:

In the matter of the Complaint against Egbert C. Smyth and others, Professors in the Theological Seminary at Andover.

\section{AMENDED COMPLAINT}

To the Reverend and Honorable the Board of Visitors of the Theological Seminary at Andover:

Pursuant to a decree of your Honorable Board, passed October 25th, A.D. 1886, the undersigned respectfully ask leave to file the following amended complaint against Rev. Wm. J. Tucker, D.D., Professor of Sacred Rhetoric in said Seminary, to wit:

We charge the said Wm. J. Tucker, Professor as aforesaid, holds, maintains and inculcates, doctrines not according to the terms and conditions prescribed by the Statutes of the Foundation of said Seminary, but antagonistic to the same.

And for further specification of Complaint, we beg leave to refer to the Amended Complaint this day presented to this Honorable Board by the undersigned, against Egbert C. Smyth, Brown Professor of Ecclesiastical History in said Seminary, and to make the charges and specifications therein contained a part of this complaint in all respects as fully as if said charges were herein set forth in the same words.

\begin{tabular}{cl} 
& J. W. Wellian \\
A true copy & H. M. Dexter \\
Attest: W. T. Eustis, Sec'y & O. T. LANphear \\
& \multicolumn{1}{c}{ J. Blaisdell } \\
By \\
Boston, Massachusetts & \multicolumn{1}{c}{ AsA Freich their Att'y } \\
8th November, 1886 &
\end{tabular}


Then follow the original specifications enlarged by further citations from "Progressive Orthodoxy" and from the "Andover Review."

There were certain formal respects in which the "Amended Complaint" differed from the original complaint.

(1) The charges were made against the accused professors individually rather than collectively - referring in each case for specifications to the Amended Complaint against Egbert C. Smyth, the charges and specifications therein contained to be made a part of this complaint.

(2) The more general charges of the original complaint were withdrawn or reduced to the simple charge that each professor named "holds, maintains, and inculcates doctrines not according to the terms and conditions prescribed by the Statutes of the Foundation of said Seminary, but antagonistic to the same."

(3) The complainants laid aside their assumed representative character and signed the complaint as individuals.

(4) The "Amended Complaint" was presented to the Visitors through legal counsel, who now appear in the case for the first time.

The "Amended Complaint," though simplified, did not remove the doubt created by the original complaint as to the specific object of the charges. In general, each seemed to point to a trial for heresy; but this purpose was vehemently denied by the chief complainant. Just before the publication of the "Amended Complaint," Dr. Dexter had sent the following communication to the "Boston Evening Transcript":

To the Editor of the Transcript: On my return from an absence of three weeks in the interior, my attention is called to the fact 
that sundry journals, and your own among the number, have intimated that the odious theological methods of the fifteenth century are being revived in order to attempt, before the "proper authorities," to crush for heresy sundry professors in the Theological Seminary at Andover. I beg to say that the only suit against those gentlemen to which I am a party, and the only one which I know anything about, is a friendly one, to determine whether or not they are guilty of perhaps the most stupendous breach of trust of a century not unmarked by such crimes. One would think that in a community of high-minded merchants and ingenuous business men such an endeavor would be received with a decent candor, rather than a spirit of persistent, if not malignant misrepresentation.

I have the honor to be

Faithfully yours

Henry M. Dexter

The Congregationalist

No. 1, Somerset Street, Boston

Oct. 23, 1886

Doubtless this communication correctly expressed the animus of the complainants, but the idea of a criminal indictment was in no respect agreeable to their legal counsel. When pressed by Judge Baldwin at the opening of the trial to state the specific charge, Judge Hoar replied with some impatience, "These gentlemen are charged with heterodoxy. Our position is that it is heterodoxy because the framers of this Andover Creed have required a certain conformity to that creed; and the sole question which we present for decision before the Board of Visitors is whether they have departed from it or not."

As between Judge Hoar's charge of limited "heterodoxy" (heterodoxy, that is, limited to variance from the Andover Creed) and Dr. Dexter's indictment for "breach of trust," there seemed to be a wide difference, but it was finally seen to resolve itself into the difference between 
the excited feelings of the complainants and the cool judgment of their counsel. Non-conformity to the Creed might possibly be interpreted as a breach of trust; but before that interpretation could be put upon it, it was certainly necessary to prove the charge of non-conformity.

The issue as presented to the Visitors through the "Amended Complaint," though somewhat simplified, was not so simple as it appeared to be. It had an historical background. The questions involved were broad and fundamental. They were such as these - What was the nature of the obligations assumed by subscription to creeds on religious foundations? What had been the usage in subscription to the Andover Creed? What was the theological intent and purpose of the Creed itself? These were questions of vital interest affecting all institutions founded or endowed under obligations to a creed. They invited the most thorough and in every way competent treatment.

The counsel brought into the trial were men of unusual fitness for their duty - on the part of the complainants Judge Rockwood Hoar, Judge Asa French, and Arthur H. Wellman, Esq., son of one of the complainants; on the part of the defendants, Judge Theodore W. Dwight, of New York; Professor Simeon E. Baldwin, of the Yale Law School; Judge Russell, a former Visitor; and ex-Governor Gaston. Of these the most picturesque figure was Judge Hoar, partly through his personality, and partly because of the open and often humorous expression of his mental attitude toward the controversy - "a plague o' both your houses."

The trial was set for December 28, 1886, and continued through January 3,1887 . It was held in one of the large 
dining-halls of the United States Hotel, Boston, which had been converted under the interested supervision of the landlord, Tilly Haynes, into a rather imposing and altogether convenient courtroom. The number of adjacent apartments suitable for retiring and conference rooms added much to the convenience of the "court." The attendance at all the sessions was large; often the hall, seating several hundred, was crowded. The interest extended beyond the friends of the Seminary or of the parties immediately concerned, and beyond the religious public, attracting the attention of many lawyers and business men. The proceedings were fully reported, and editorially commented upon, by the daily press.

The absence of two interested parties from any formal participation in the trial called forth considerable comment: the absence of students as witnesses, explained by the fact already mentioned that the outspokenness of the "Review" had precluded any necessity for the invasion of the classroom to secure, if possible, testimony adverse to the accused professors; and the absence of the Trustees in their official capacity, due to the refusal of the Visitors to recognize them as a party to the trial. The enforced absence of the Trustees from this cause was to have a decisive bearing upon the final issue of the "case."

The trial was carried on in the main according to the routine of legal procedure. The argument of the counsel for the complainants was based upon the stringency and explicitness of the terms of the Andover Foundation. The revised Creed, which was a part of the compact between the original and associate founders, was to be an unchangeable document. Subscription to such a creed assumed its literal interpretation. This was the burden of 
the argument of both Judge Hoar and Judge French. Dr. Dexter argued, out of his familiarity with the history of the New England churches, that any omission from the Creed of a definite condemnation of the theory of a possible future probation could not be construed as allowing the theory - a theory which was not accepted, and would not have been tolerated at the time when the Andover Creed was written. He introduced a vast amount of documentary evidence from the creeds of the churches, and from sermons, to show the state of belief at the time. Dr. Wellman took up the charges, specification by specification, to show that in all the cases specified the holdings of the accused professors were out of harmony with the Creed, and subversive of its plain requirements.

The defense began with an elaborate review by Judge Dwight of the history of English charitable and religious foundations, showing how they had been construed in the English ecclesiastical courts, and in the courts of law. Professor Baldwin continued the legal argument by showing how the Andover Foundation had actually been construed, and introduced the testimony of the more recently inaugurated professors to prove the latitude allowed in the terms of subscription to the Creed. Judge Russell laid special stress upon the fact that the Board of Visitors had already passed upon the very issue now before them, when they declared that "the Visitors have been convinced of the general harmony of Dr. [Newman] Smyth's theological views with those which have been identified with the history of Andover Seminary from the beginning." The argument of Professor Smyth, whose case had been made by agreement that of all the accused professors, was a surprise to the complainants, in some 
respects a disconcerting surprise. Instead of making it a personal defense or a defense of his colleagues, it was a bold and aggressive defense of the Andover Creed, proving by careful historical testimony and by equally careful analysis that it was not an antiquated or reactionary document, but rather one of the landmarks in the history of theological progress. The unchangeableness which had been insisted upon by the Associate Founders was not to prevent progress, but to give the necessary assurance against retrogression. An instrument so conceived and guarded could not be used in after times as obstructive to theological progress, nor could its unchangeableness, so solemnly insisted upon, be construed into an argument for literalness in interpretation. The relatively brief statements of the other professors were simply supplementary to this argument, having to do with the special provisions pertaining to their respective professorships. What was of more significance was their direct testimony in regard to the terms of their individual subscription to the Creed, which had been tacitly or expressly sanctioned by the Visitors. ${ }^{1}$

I think that I was the first to make a public statement

1 I have given in mere outline the running course of the arguments on either side. The arguments ran through five days, of two sessions, and occupied on the average four hours each. For any analysis of the content of the arguments, the reader is referred to the reports of the Boston papers, and of the Springfield Republican covering the dates, December 28, 1886, to January 4, 1887; to the files of the Congregationalist preceding and following the trial; to the files of the Independent for January 6 and 13, 1887, giving substantially a verbatim report; and to the Andover Defense, in which all the arguments of the counsel for the defense, the argument of Professor Smyth and the statements and testimony of his colleagues are given in authorized form in a book of 315 pages. I am not aware of any like publication presenting the case of the complainants. The proceedings before the Supreme Court on the appeal of Professor Smyth and on the petition of the Board of Trustees are matters of court record. The findings of the Visitors and of the court are recorded from time to time in the Andover Review. The final record appears in the November number, 1892. 
at the time of signing the Creed. What I then said appears from the following record.

Q. (By Judge Baldwin.) Will you state, Professor Tucker, whether anything was said by you as to your subscription to the Creed at the time of your induction into office?

A. I find this statement which I made upon my subscription to the Creed, July 1, 1880. I did not meet with the Board of Visitors upon my election, not having been notified by them of any call to that effect. When I took the Creed I took it reading this statement before subscription: "The Creed which I am about to read, and to which I shall subscribe, I fully accept as setting forth the truth against the errors which it was designed to meet. No confession so elaborate, and with such intent may assume to be the final expression of truth, or an expression equally fitted in language or tone to all times."

\section{Cross-Examination}

Q. (By Judge Hoar.) You say that accompanied your signature to the Creed?

A. It was not copied into the book; the reading of it accompanied the signature.

Q. You read that at the time when it was proposed to you, you should sign the Creed, and then you signed the Creed without putting down more than your name?

A. Simply my name.

Q. And to whom was this exposition given?

A. This was given in the presence of the Trustees and Visitors so far as present. I do not remember who were there; it was a public inauguration.

Q. It was not a matter of consultation with the Visitors beforehand, as to whether that would be all that the constitution of the Seminary would require?

A. It was not. I made the statement before reading the Creed, then read the Creed, and, no objection being made, signed the Creed after that statement.

The material point in this testimony is not the state- 
ment of the sense in which I took the Creed, but the fact that I stated there was a sense in which I could fully accept it, and another sense in which $I$ regarded it as incomplete and insufficient.

The testimony of Professor Harris and his colleagues, who took the Creed two years later at the time of their inauguration, discloses the form upon which they agreed in their subscription - a form to which the Visitors gave their sanction. The testimony of Professor Harris covers the case of the others:

Q. (By Judge Baldwin.) State, if you please, Dr. Harris, what were the circumstances attending your assent to the statutes and Creed of the Seminary at the time of your receiving the appointment to the professorship you now hold.

A. We submitted to the Visitors - I think I was the person who submitted it - a proposal of the form in which we were willing to take the Andover Creed, which, as nearly as I remember, was this: "I accept" (my uncertainty is as to that word "accept") "this Creed as expressing substantially the system of truth taught in the Holy Scriptures." The proposal was, to accompany our signatures, either in writing or orally, with this statement, when the Creed should be publicly taken. To this the president of the Board replied that there was no objection to it, and that for his own part, he thought it would have a good effect in the existing state of public opinion. I do not, of course, quote the language, but the statement in general. I am not aware that the Board of Visitors passed any formal vote in this matter, but it was a distinct understanding, considered on our part as having somewhat of the nature of an agreement with them, that we should take the Creed under those conditions. When the time of our induction into office came, the Creed was so taken by each of us, with the statement which I have designated, and, as we understood, with the sanction, not only of the Board of Trustees, but also with the sanction of the Board of Visitors. 
The trial before the Visitors closed on the 3d of January, 1887. Five months later, June 17, the Visitors rendered their decision, condemning Professor Smyth for holding views contrary to the Creed of the Seminary and removing him from his professorship, but passing no judgment upon the theological views of his associates and leaving them undisturbed in their chairs. The decision at once aroused a deep sense of injustice, equaled only by an impatient desire to know through what subterfuge such a miscarriage of justice could have been effected. The length of time taken in preparing the verdict precluded the possibility of an undesigned or accidental cause. In the absence of any explanation from the Board conjectures were rife. The calculation, based upon a plausible analysis of the vote, which was afterward confirmed by direct legal testimony, was to the effect that President Seelye voted to acquit all the accused professors, such a vote being regarded as consistent with his vote on a previous occasion rejecting Dr. Newman Smyth on other than theological grounds; that Mr. Marshall, the new member of the Board, voted to condemn all; and that Dr. Eustis voted to condemn Professor Smyth, but declined to vote in the case of his associates - the how and why of his action being undetermined. It appeared later, from the records of the Board, that Dr. Eustis excused himself from voting on the cases of the four professors in question, on the ground that he was not present at the session when they made their individual statements. His absence at the time was noted and the attention of the Board was called to the fact. The Board ruled that his absence would in no way invalidate the proceedings, provided a stenographic report was made to be submitted to Dr. Eustis, and ordered 
the continuance of the session. This ruling was accepted by the counsel for the complainants. The provision was complied with and an accurate stenographic report was in due time submitted. The ruling of his associates did not, however, seem to satisfy the scrupulous sense of honor on the part of the Secretary of the Board, and he refused to take advantage of it. "A similar instance of so delicate a sense of propriety," remarked an editorial critic, "has never come to our knowledge." The question why Dr. Eustis declined to vote for the removal of all the accused professors, in view of his outspoken denunciation at various times of all concerned, was never clearly answered. The uncontradicted rumor was current that this evasive action was taken in the fear that more complete and drastic action involving the practical reorganization of the Faculty, would disrupt the Board. Upon this supposition, the Board did not anticipate what would have followed if the associates of Professor Smyth had taken his dismissal as a finality, namely, their inmediate resignation.

According to Art. XXV, Statutes of the Associate Foundation, "the Board of Visitors in all their proceedings are to be subject to our Statutes herein expressed, and to conform their measures thereto; and, if they shall at any time act contrary to these, or exceed the limits of their jurisdiction and constitutional power, the party aggrieved may have recourse by appeal to the Justices of the Supreme Court of this Commonwealth for the time being. for remedy; who are hereby appointed and authorized to judge in such case; and, agreeably to the determination of a major part of them, to declare null and void any decree or sentence of the said Visitors, which, upon mature 
consideration, they may deem contrary to the said statutes, or beyond the just limits of their power, herein prescribed; and by the said Justices of the Supreme Judicial Court, for the time being, shall the said Board of Visitors at all times be subject to be restrained and corrected in the undue exercise of their office."

At the close of a previous article (XX), after prescribing the spirit and manner in which certain specific duties shall be performed, the Visitors are enjoined "in general, to see that our true intentions, as expressed in these our Statutes, be faithfully executed; always administering justice impartially, and exercising the functions of their office in the fear of God, according to the said Statutes, the Constitution of this Seminary, and the Laws of the Land."

On the general ground that the Visitors had not "administered justice impartially" in the decision rendered, Professor Smyth took his appeal, according to the provision of Article XXV, to the Supreme Court of Massachusetts. The specifications in this appeal were concerned entirely with the behavior and action of Dr. Eustis, Secretary of the Board, in his judicial capacity; charging him with partiality and prejudice, and with having, at various times and places, openly prejudiced the case.

Pending the course of this appeal Professor Smyth was entitled to resume his duties as Professor of Ecclesiastical History. This he did, and the affairs of the Seminary went on without interruption during the ensuing trial.

A bill of complaint by the Trustees was also submitted to the court, based on the refusal of the Visitors to allow the Trustees to appear as a party to the "trial." It was claimed that this denial of the rights of the governing 
Board was a usurpation of visitorial power; and after reciting the course of action on the part of the Visitors following this refusal and leading up to their decision, the Trustees ask the court for "light" as to the principles on which they are to administer the trust committed to them, under so "contradictory and insensible" a verdict. The statement of the dilemma in which the Trustees find themselves is so clear that $I$ give it in full in a footnote. ${ }^{1}$ The

1 "Forty-first. And the plaintiff says that under the pretended judgments, decrees, and conclusions aforesaid, as recited in said communications from the $V$ isitors to the plaintiff, four of the accused professors were acquitted, and one of the accused professors was convicted, upon precisely the same charges. supported by precisely the same proofs in the case of each of the said five professors; so that in case the action of the Visitors constitutes in law a legal visitation, if the said judgments, decrees, and conclusions of the Visitors are correct and proper either as to the professors acquitted or the professor convicted, they are manifestly wrong as to the other or others, and the same are contradictory and insensible; that the plaintiff, as charged with the duty of administering the trust reposed in it, is left without light as to which judgments are correct, or upon what prineiples the Visitors intend to declare that the trust as to said foundations should be administered; and that, if the defendant Smyth has violated his duties as professor, then the said defendants, Churchill, Tucker, Harris, and Hincks have violated their duties as professors, and the plaintiff ought not any longer to allow them to teach as professors in their respective professorships, and ought not to pay them any salaries out of the funds appertaining to such professorships.

"Forty-second. And the plaintiff further says that, by reason of the matters and things herein set forth, the proceedings of the Visitors, and their pretended judgments, decrees, and conclusions herein set forth, if not inquired into by this Honorable Court, but left to stand, will constitute a cloud upon the title of the plaintiff to direct and manage the affairs of Phillips Academy, and render the plaintiff uncertain as to its duties in the premises, and will greatly embarrass and impede the plaintiff in the administration of the trusts as aforesaid confided to it, and will expose the plaintiff to a multiplicity of suits, according as it takes the one view or the other of its legal duty in the premises; and that it is imperatively demanded for the peace of Phillips Academy, and specially of the theological Seminary therein, and the due administration of the various charitable trusts connected therewith and held by the plaintiff as trustee as aforesaid, that the questions arising out of the matters and things hereinbefore set forth shall be definitely adjudicated and settled by the decree of this Honorable Court in the premises.

"Wherefore, the plaintiff prays this Honorable Court to instruct and inform the plaintiff what authority and jurisdiction, if any, the Visitors have over the defendants Smyth, Churchill, Tucker, Harris, and Hincks, or either of them; whether the proceedings of the Visitors, and their judgments, decrees, and 
Trustees further ask for such an interpretation of the relative authority and functions of the two Boards as may enable the administrative and visitatorial parts to act in harmony, or if this be impracticable that the relation between the two be modified or dissolved.

The counsel on either side employed in the trial before the Visitors were retained for the trial before the Supreme Court, with their positions reversed, and in behalf of the Trustees Professor Gray, of the Harvard Law School, George O. Shattuck, Esq., of Boston, and Judge Bishop, a member of the Board of Trustees, were added. As the bill of the Trustees involved a thorough investigation of the law of Visitation, Judge Bishop went to England to make a study of the law as applied to English institutions.

When the appeal of Professor Smyth and the bill of complaint of the Trustees came before the Supreme Court, it was necessary that two special hearings should be assigned by the court - one to secure a correct and complete record of the proceedings of the Visitors in connection with the "trial"; and one to secure the requisite testimony relative to the charge against Dr. Eustis, Secretary of the Board, of having through private and public utterances at various times and places prejudiced the case. Justice Allen was assigned to the hearing on the record of the Visitors, and ex-Governor Robinson was assigned to take testimony upon the charge of prejudgment against Dr. Eustis.

The two cases, which were practically merged in one,

conclusions herein set forth and referred to, or any of the same, are void; and whether by reason of said judgments, decrees, and conclusions, or any of them, the plaintiff ought to refrain from paying to the defendants Smyth, Churchill, Tucker, Harris, and Hincks, or either of them, the income of the funds appertaining to the professorships respectively, in which they have been severally inducted; and whether it ought to refuse the said defendants, or any of them, leave to teach in their said respective professorships." 
were nearly three years before the court. There were several points at which a decision might have been rendered, any one of which might have yielded the same result. The point which the court chose was the refusal of the Visitors to allow the Trustees to become a party to the "trial." This refusal, in the judgment of the court, was a fatal error on the part of the Visitors. "We are of opinion," the court says, "that the action of the Visitors was not in accordance with the statutes which they were trying to maintain and that their decree must be set aside." "It is inconceivable," the court had previously said, "that a Board of Visitors intending to be governed by principles of justice should for a moment think of refusing the managing body a hearing in a case where the proceedings are directly against it to set aside its action." The opinion was written by Justice Knowlton and concurred in by Justices Allen, Holmes, Morton, Lathrop, and Barker. Chief Justice Field dissented on the ground that the decision did not reach the merits of the case. "I refrain," he said, "from expressing any opinion on the merits for the reason among others that there may be a new trial of the Complaint by the Visitors, and another appeal to this court."

The decision was related more closely to the bill of the Trustees than to the appeal of Professor Smyth, but the hearing before ex-Governor Robinson on the competency of Dr. Eustis to act as a judge established the fact by the mouth of many witnesses that he had prejudged the case. The effect of the decision, though reached through the case of the Trustees, was to reinstate Professor Smyth in his chair, as also to put certain limitations upon the power of the Visitors. The testimony before ex-Governor Rob- 
inson so clearly invalidated the judgment of Dr. Eustis, that it would have served to change the vote of the Visitors in the case of Professor Smyth, had the court based its opinion on that issue. By the Statutes of the Associate Foundation, in case of a tie in the vote of the Board of Visitors, the vote of the President is made decisive. The elimination of the vote of Dr. Eustis would have meant the acquittal of Professor Smyth.

The dissenting opinion of the Chief Justice naturally suggested a reopening of the complaint before the Visitors. The complainants proceeded to carry out the suggestion. During the time, however, in which the case had been before the Supreme Court - nearly three years - certain changes had taken place affecting the entire situation. Dr. Eustis had died (1888) and Dr. Dexter (1890) and in the same year Professor Park. Meanwhile the Board of Visitors had become practically a new Board. President Seelye had resigned and been succecded by Dr. George Leon Walker as President; and the vacancy occasioned by the death of Dr. Eustis had been filled by the election of Dr. Alonzo H. Quint. Mr. Marshall remained on the Board and was made Secretary. It had become apparent, as the proceedings went on before the Supreme Court, that the case was turning more and more away from its theological aspects toward its administrative bearings. There was a liability that the case might be carried to the Federal Courts upon the question of the constitutionality of the visitorial system. Meanwhile the change which had taken place in the personnel of the Board of Visitors placed the determining power in the hands of the new members, Dr. George Leon Walker, the President, and Dr. Alonzo H. Quint. In view of these two facts, it was 
proposed by some of the supporters of the Seminary, including at first two or three of the Trustees, that it might be well to withdraw the case from the Supreme Court and restore it to its original theological status, by resubmitting it to the reconstituted Board of Visitors. I find by reference to correspondence, that this proposal was seriously entertained by some who were directly concerned with the affairs of the Seminary. But upon consultation this proposal was dropped. It was seen to be essential that there should be a decision upon the administrative as well as upon the theological points at issue. Such a decision could come only from the Supreme Court. It was also seen that it would be difficult, even under general agreement, to bring the case back again into the unquestioned jurisdiction of the Visitors. And still further, the move might reopen all the old sources of contention; and in the renewed confusion allow some compromising decision - as, for example, a vote of acquittal accompanied by admonition. It was therefore decided with practical unanimity that the case should go on, with the result already stated.

After the decision was rendered it was uncertain what course the complainants would take. The dissenting opinion of the Chief Justice had opened the way, should they choose to use it, for a renewal of their complaint. The situation, however, as has been noted, had changed in some important respects. I recall the more important. There had been the change in the composition of the Board of Visitors. Dr. Dexter, the chief complainant, had died. Professor Park, to whom the complainants had turned for advice, had also died. With the accession of Dr. Dunning to the editorship of the "Congregationalist," the 
burden of the attack upon Andover had been shifted to the columns of the "Advance." These changes represented apparent losses. On the other hand, the original controversy had been carried on unremittingly in the rooms and upon the platform of the American Board. It was a significant fact that when the complaint was actually renewed, and an early date for the hearing had been appointed, the complainants requested a postponement until after the fall meeting of the American Board.

The uncertainty in regard to the action of the complainants was set at rest by notice served July 11 upon the Trustees and Professor Smyth that the "Amended Complaint" would be renewed by the remaining complainants, Drs. Wellman and Lanphear, and that a hearing had been appointed for September 1 at Andover. It was difficult to know just how much this meant. There was no wish to distrust or embarrass the new Board of Visitors through irritating preliminaries on the part of the defendants. Such, for example, might have been the proposal, very seriously entertained, that the four professors who had been acquitted should petition the Visitors that they be included in the renewed complaint. Their position had been very embarrassing. Had the dismissal of Professor Smyth resulted in his retirement, they would have resigned. Should his dismissal on the renewed charges be made final, they would resign. But their proposed reentrance into the case introduced such complications that it was decided to put by the proposal. It was, however, necessary to take account of the decision by the court, modifying the powers of the Visitors and their method of procedure, and to take such steps as might insure a suitable ground of appeal should it be necessary for either 
the Trustees or Professor Smyth to resort again to the court. The reply of the defendants took due account of these precautions; and Professor Smyth made in addition a brief but frank reply covering the theological charges involved. The hearing was held as appointed on September 1, and at its close was adjourned for one week. At that time the Visitors made their deliverance, covering in somewhat minute detail their interpretation of the decision of the Supreme Court as affecting their Visitorial powers, and concluding with the statement of their reasons for the decision which they reached regarding the disposition of the case against Professor Smyth.

It must be remembered [they say] that this amended complaint was dated November 8, 1886, and that the burden of such complaint claimed that the respondent held and maintained certain alleged errors nearly six years ago. An adverse decision would now merely assert that to have been a fact. The present condition of affairs is not involved in the specific question at issue. ...

It has a moral bearing, furthermore, that upon the former hearing, upon verbally the same complaint then made against five professors alike, and upon the same evidence in all the cases, four of the accused were acquitted, and one (the present respondent) was condemned. That this infelicity arose from a conjunction of circumstances within the Board itself does not affect the bearing of the fact. The conditions of that result have never been generally understood, and a necessary and ineritable prejudice was auakened against the equity and the reasonableness of the adjudication made. ...

To some extent the present complaint operates as a barrier to that more direct and current supervision of the affairs of the Seminary as a whole, which has been indicated as a duty recognized by the Visitatorial Board, and especially to those amicable methods which should take precedent of all others. 
In the peculiar condition, therefore, where this protracted case is now found, and in its evident inadequacy to advance the interests of the Seminary, and in the unlikeliness that this isolated case would be productive of good by further proceedings, and in the belief that the Visitors can better fulfill their responsibilities by other methods within their power, this Board decides - without thereby expressing any opinion upon the merits of the case - that the amended complaint now pending against Egbert C. Smyth, Brown Professor of Ecclesiastical History, be dismissed.

Thus ended finally the "Andover Case" after a course of six years, preceded by two years of open controversy. Following the movement of the case, we have these successive steps - the formal complaint before the Board of Visitors against five professors in the Seminary on the general charge of heresy; the amended complaint, becoming more distinctly according to the declared purpose of the complainants, an indictment for breach of trust, though held formally to the charge of heterodoxy; the trial before the Visitors; the unequal verdict which dispossessed one professor of his chair, leaving the other professors undisturbed; the transfer of the case to the Supreme Court of Massachusetts, through the appeal of the dispossessed professor on the ground of the prejudgment of the case by one of the Visitors, and through a bill in equity brought by the Trustees on the ground of having been denied a place by the Visitors as a party to the trial; the discussion before the court of the relative authority and powers of the governing and Visitatorial boards; the decision of the court declaring the judgment and decree of the Visitors void on account of their violation of the Statutes defining their powers; the reopening of the case before the Visitors by the remaining original complainants 
through the "Amended Complaint"; the reversal of the decision made by the Board in the earlier trial, and the formal dismissal of the case.

The results of this protracted controversy and litigation cannot be as succinctly stated, but they were at certain essential points clear and impressive.

Owing to the circumstances attending the development of the trial, peculiar interest attached to the personal result. I have said that Professor Smyth was the outstanding figure. He was such by rightful distinction, by virtue of what I may term his personal and professional correspondence to the issue involved. Professor Smyth had been reckoned a conservative rather than a liberal, according to the way men were classified before the opening of the Andover controversy. I am not sure that he would have become so aggressively advanced on any of the other questions which were opening the way into progressive orthodoxy. I am quite sure that he would not have been fitted by temperament or by training for leadership in the distinctly scientific movements in some parts of the theological world. But for the truth underlying the Andover "heresy," which, as he believed, touched the very heart of Christianity, he was fitted both by his sympathies and by his studies to act as its defender and advocate. He was a wide and profound student of Christian history, especially of the history of Christian doctrine. When calling in question some of Dr. Dexter's claims for certain creeds as œcumenical, he was able to say with unimpeachable authority - " they are not œcumenical, I know these all by heart." He was likewise profoundly sensitive to the humanity of Christianity. Here was the secret of his zeal 
for missions. As a speaker on the platform of the American Board he was no longer the Church historian, but a valiant and moving pleader for the rights of all men in the Christian heritage and the Christian hope.

As the circumstance of the trial detached him from his colleagues, he carried the distinction which this detachment conferred upon him with dignity, courage, and genuine simplicity. His legal opponents were impressed by his behavior and carriage. He did not ask for sympathy or invite it. He stood four-square against the adverse circumstances creating his isolation, which in spite of the oneness of all concerned in the struggle had its painful realities. His patient strength lay in the satisfactions of duty, and in the undaunted assurance of the ultimate success of his contention. There was not a little of the spirit of Luther in the concluding words of his defense: "What I maintain and where $I$ abide in good conscience is this: I have not violated my obligations under the Creed, even upon a close and technical construction of them. And if, as I also maintain, the Creed is a summary of principles which are to be applied and developed from generation to generation, I have done something far better and more faithful than a literal repetition of them. I have used them, and with them have confronted present great and important questions of religious thought and life." The vindication of the man whose whole course of action justified such words as these, was not to be overlooked in any fair estimate of the greater results of the trial. It was no mere sentiment which led the public to regard the culmination of the trial, in the restoration of Professor Smyth to his professorial standing in the Seminary, as of the nature of a personal triumph. 
An uncalculated, but salutary result of the trial was its exposure of the folly of the over-use of theological safeguards. The Andover Foundation was guarded by an elaborate creed, which in turn was guarded by a carefully devised system of visitation. The Creed was calculated, by reason of its excessive specifications, to confuse the mind as to its essential purpose and as to its actual tendency. Even so fundamentally honest and so acute a mind as that of Judge Hoar failed to discern its actual bearings. It remained for Professor Smyth to point out by a careful historical analysis the real direction of the Creed; to show that it had a forward, not a backward, look, and that its restrictions were set up to guard against retreat, not against advance. In like manner the visitorial system was so devised as to create unwittingly the very liability to inconsistency and injustice which has been so deplorably in evidence. The Board of Visitors which dismissed the case against Professor Smyth, charitably characterize the injustice of the action of their predecessors as an "infelicity (which) arose from a conjunction of circumstances within the Board itself." It is due to the Founders to note their wisdom in the provision they made to correct any miscarriage of justice on the part of the Visitors. They put the Visitors within easy reach of the Supreme Court. They had the sagacity to see that men of religious character and purpose were not infallible in the exercise of justice; that in fact religious zeal might divert their steps from the straight and narrow path of justice. The Seminary and the churches are indebted to the Supreme Court of Massachusetts for its clear apprehension of the claims of justice in their decision in the Andover case, although it kept as far away as possible from the theological issues 
involved. The decision would have been still more satisfactory had it entered more fully into the relations between the two boards, though as I have said in the section of this chapter bearing on the proposed action of the Trustees in the establishment of a new chair free from visitorial jurisdiction, it was only in this way that real institutional freedom could have been gained. It would have been sufficient to have made the visitorial system a subordinate, rather than as it is now, the dominating part of the Foundation. Andover has been somewhat relieved of the excessive burden of its safeguards, but it is still too heavily weighted with its defensive and offensive armor to act in possible contingencies in the full freedom of its strength.

The result which was most definitely secured, through the protracted trial - the result, that is, which was actually reached, and which could only have been reached through conflict, was a reasonable assurance of theological freedom. This result was the answer to those who deprecated the fight and would have been willing to divert the issue. It represented something achieved, something won. The fact that it was reached through a reversal of judgment made the victory more complete. Between the original judgment and its reversal, public sentiment had grown into an almost unanimous approval of the freedom secured. Very few feared any danger from it. The long struggle had familiarized the public mind with the spirit and intent of the larger freedom. The danger from acquired freedom is indeed quite different from the danger of inherited freedom. It is more obvious, but really less to be feared. The utmost danger from acquired freedom lies in the possible tendency to over-use it. The danger from inherited freedom 
is not license but stagnation. This danger had begun to mark the freedom of the New England churches of the Puritan faith. The New England theology had begun to stagnate. Its great traditions were no longer urging it forward, and it was not sensitive to the stirrings of the new life from without. By contrast, any theological freedom like that won in the Andover fight was safe. It was a freedom to be respected, and trusted. A very significant change in this respect was indicated in the final decree of the Visitors, in their reference to subscription to the Creed. All suspicion and distrust had now passed away. "Since the date of the Amended Complaint," they say, "that person [Professor Smyth] has again subscribed to the creed of the Seminary as required by the Statutes; a creed which this learned and Christian gentleman must be supposed to have taken intelligently." "Intelligently," not literally, not evasively, but in consistency with his well-known views, and in accordance with his declared understanding of the Creed itself. Here at last is the full recognition of the right of personal interpretation in the matter of creed subscription. The Andover conflict brought to those who won the rights which they defended, and through them to all who set a proper value upon theological freedom, the possession of a responsible and respected freedom. "Suffice it to say," is the conclusion of an editorial writer in the secular press who had carefully watched the whole course of the conflict, "that there seems to be no longer any question that Progressive Orthodoxy is orthodox; and that its progress is in the direction of bringing, by methods adapted to the conditions of to-day, to bear upon the needs of to-day, that gospel which is the same yesterday, to-day, and forever." 
It is much to say of the result of the Andover trial that it secured a larger theological freedom for the Seminary its professors and students and graduates - and also for theological education everywhere and for the ministry at large; but it is far more to be able to say, as I think it can truthfully be said, that the Andover controversy, of which the trial was the culmination, contributed its part toward that vastly greater end of theological freedom, namely the freedom of Christianity. Much as it means for men to be free in their holding of the Christian faith, it is infinitely more that the faith itself shall be kept free, or if in any wise bound, shall be set free. The great struggle within the field of doctrine has always been to break the hold of fettering and restrictive dogmas. These dogmas have been the obstructive forces in the way of a working Christianity, - the dogma of a "particular" election, the dogma of a limited atonement, and, last, the dogma of a restricted opportunity. It was a sad comment on the assumed and even boasted freedom of the New England theology, of which Andover was a chief exponent, that a theology which had won the conflict for a universal atonement should surrender to the dogma of a restricted Christian opportunity; and that the missionary organization called into being to carry out the motive of a universal atonement, should shift its motive of action to this same dogma of a restricted Christian opportunity. It was this arrested development and perverted application of an otherwise advanced theology, which made the Andover contest in the courts, and the Andover contention in the American Board, one and the same conflict. And the result? Who now holds in good faith the doctrine of a universal atonement, compelled at the same time to limit 
its application to the merest fraction of the human race? Who now holds a working interest in missions, compelled at the same time to find the motive to missions in the arbitrary limitation of the Christian opportunity? The conception of a future opportunity for those who have not known or understood the Christ, denounced as a fatal heresy, derided as a speculation, to be allowed if at all only as a hope, was given its true place in the larger interpretation of Christianity. It is no longer merely a possible inference, it is seen to inhere in the spirit and intent of the Christian faith; a faith which is constantly extending its boundaries and becoming more and more capable of including within its range the possibilities of the future world; a faith which follows with unfaltering step the path of every man on his way to his final destiny. This progress of Christian faith can be measured not simply by the enlargement of its range, but still more by the quickening of its hope into confident expectation, that expectation which glows in the epistles of St. Paul. The greatest advance of Christian doctrine within the generation has been in its humanity. The humanizing process has been at work in many ways, but in all those ways that are most accessible and most easily recognized, it has been stimulated by that larger hope for humanity which is the outcome and expression of the newly acquired freedom of Christianity. As the meaning of this enlarged freedom is more clearly understood, it is reasonable to assume that the inspiration to be derived from it will act with increasing force upon the Church. Under the intense individualism of the Protestant faith, the churches of that faith have never caught the large vision, or felt the deep sense of humanity. We, who profess that faith, have hardly 
recognized, certainly we have not felt, the solidarity of the race. But the Christianity of the New Testament and of the early Church was conceived and announced in universal terms. Nothing has yet been accomplished, taking full account of the glorious work of the past in some transformations of life among some peoples, nor is anything in immediate prospect, which can be accepted as satisfying the spirit, or the purpose, or the capacity, or the prophecy of Christianity. Is there a larger work in human redemption going on out of sight, but not out of the reach of faith? ${ }^{1}$ The Christian heart, and the Christian mind, and more and more the Christian conscience have contended for the right to believe in this unlimited work of Christ. "We must cast ourselves," said one of the earlier converts to Christianity - "we must cast ourselves into the greatness of Christ." The conviction which found such courageous expression in the saying of this early convert has grown, all too slowly, but irresistibly, upon the Christian Church. Every period of greatest advance has been marked by some sincere attempt to realize its meaning. I think that it may be claimed for the Andover Contention, that it was a sincere attempt, successful within the limits of its influence, to embolden Christian believers to cast themselves more completely into "the greatness" of Christianity, and to adjust their Christian activities and expectations to this enlargement of their faith.

1 No one can overlook the fact that the War is giving a reality and pertinency to this question which could hardly have been anticipated when it was under theological discussion. It is now a human question. The War has brought the two worlds very near to one another in the minds of multitudes, even in Christian homes, who had been living in one world; and the constantly increasing volume of premature deaths makes its direct and irresistible appeal to Christian faith.

W. J. T. 1918. 


\title{
CHAPTER VIII
}

\author{
ANDOVER AND DARTMOUTH
}

1892

A Year of Painful Decisions

The year 1892 was the most personal year in my professional life. The changes which it brought were sensitive and far reaching, vitally affecting the home, and all those intimate associations in which one's life takes root. The essential change was a sharp and sudden turn in my career, producing an immediate personal effect like that of the shift of a train on taking a double curve at speed.

Early in the month of February I went to Hanover, New Hampshire, to attend a meeting of the Dartmouth Trustees. At that meeting President Bartlett, then in his seventy-fifth year, resigned, the resignation to take effect at the close of the academic year, and $I$ was at once elected to the presidency. The election took place without previous consultation with me, and in the brief discussion which preceded it, against my earnest protest. I urged that the conditions at Andover did not warrant my withdrawal. My colleagues urged in turn that, in view of the decision of the court in the Andover case, conditions at Dartmouth should have first consideration, and proceeded to a ballot. When the vote was announced, I formally declined the election, but my colleagues insisted that in the circumstances their action was justified, and at least called for a suspension of judgment on my part. Their argument was direct and personal. "You are a trustee of fifteen years' standing; you are an alumnus of the College 
and specially identified with the alumni movement now going into effect, upon the success of which the immediate future of the College so largely depends. Your election is quite a different matter in present circumstances from the election of an outsider. Your declination will have a different effect upon the College from the declination of an outsider. The fair obligation rests upon you to at least give the matter more thought than a peremptory answer will allow. Our action has been well considered; you should not act upon your immediate impulses or even convictions."

Naturally the situation grew more and more embarrassing under discussion. Had the Andover case been still in litigation, I could not honorably have consented even to this claim for time; but the decision of the Supreme Court of Massachusetts having virtually closed the case, though the Visitors had not dismissed it, I could not altogether deny its justice. But as the allowance of the claim would bring the whole situation before the public I foresaw an increasing embarrassment. It would naturally be assumed, as I was a trustee and present at the meeting of the Board when I was elected, that I was consenting to the election and would accept it. Still nothing remained, having admitted the reasonableness of the claim of the Trustees, but to discount as far as possible the publicity of the situation, and take the question back with me to Andover; and submit it fully to that court of last resort, one's own judgment and conscience.

Of the many letters which came to me after my return, a few were of a general character giving an estimate by the writers of the relative honor and dignity of the two positions. These letters were for the most part quite irrelevant. I had little interest in the question of relative 
honor or dignity. Each position was of so high and serious intent as to subordinate all thought of personal advantage to the one really pertinent question of effective service. Other letters of a very different sort revealed the earnestness and genuine concern of the writers for the College or the Seminary, or for the things which each represented to them. Such were the letters from the Dartmouth Faculty and from many of the alumni, in which one could read at least between the lines the hopes and fears, the restraint of enthusiasm or of disappointment in view of the uncertainty of the result. And such especially were some of the letters from stanch and loyal friends of the Seminary, who had patiently borne the years of disheartening controversy, and were now jealous of any interference with the promise of its enlarged activities. Letters of this kind naturally intensified one's feelings, without helping in any corresponding degree to clear one's judgment. In my state of mind, the most helpful words were those of persons who seemed to me to be able to judge with fairness and discrimination in regard to my fitness for the respective positions before me. I found that the question of fitness took precedence more and more of other questions. I do not know that I had ever lacked the courage to enter upon the new and untried. In fact the spirit of venture was seldom dormant. But in so grave a matter as that now at issue, I felt that a new responsibility should not be assumed in the adventurous spirit. My earlier and later training had been for professional not academic studies, and though I did not shrink from administrative work, or underestimate its relative value (much higher than that of most of my friends), I had yet to assure myself of a sufficiently evident or conscious fit- 
ness for it to compensate for the manifest loss of a considerable amount of acquired power. Whatever power of initiative I had, had gone out in a given direction. Was it wise to arrest it, apparently well under way but so far from its goal? As an old classmate wrote me in Biblical figure "God has given you your vision. You have got the tabernacle under way. Turn your back on it, and it will necessitate the evolution of another man." Or as the one of my colleagues, with whom I had the most in common in intellectual outlook, put it - "To make the proposed change would be the transfer of yourself out of a work for which you are made by special creation, into that to which at best you would be adapted by forcing." While I recognized a certain exaggeration in the terms in which these views were expressed, I could not deny what was on the whole the real fact as it then appeared, namely, that the commitment to a specialized work had given it such rights and advantages as to make it of determinative importance. In the sense of the obligation which had been thus created, I wrote the following letter to the Trustees of Dartmouth College:

To the Trustees of Dartmouth College:

Gentlemen: The circumstances, in which you put upon me the very high honor and duty of serving the College as President, have greatly increased the responsibility attending my present decision. You will recall the strenuous endeavor which I made to anticipate and arrest your action, upon the first intimation of it, owing to my conviction that my future work was already determined. The fact, however, that you thought it wise, in view of the interests of the College, to overrule my judgment, taken in connection with the expressed feeling of a large number of the Faculty and Alumni, have led me to reëxamine my position with the utmost seriousness. I have accepted in its full signifi- 
cance the private statement of one of the Board that "this consensus of judgment and feeling has created a new condition." It has been to me, I can assure you, a far more serious matter to attempt to determine my duty in the light of your action and of the opinions of others, than in the light simply of my own convictions. Still after the most deliberate and anxious thought, I am constrained to abide by the conviction which I first declared to you, and to return to you the election to the Presidency of the College.

It is due to you and to those who are vitally concerned in this decision, that I should state briefly but clearly the reasons which have led to it. The fact that these reasons center in my personal thought and circumstance may make them less convincing to you, while more imperative to me.

Twelve years ago I gave up the pastorate to enter upon the work of training men for the ministry. The change was not made without a struggle, but it was made intelligently, and with the determination to take part with those who were seeking to broaden and adjust the Christian Church to its new relations to society and the world. There were signs at the time that this expansion and adjustment would be accompanied by much discussion, perhaps by dissensions. The signs were soon verified. The past years have been years of theological and religious controversy. I have no doubt that more rapid progress has been made in this way than could have been made by any other method.

But the end of controversy, when it is reached, is not rest; it is not freedom even; it is opportunity. The chief object which, with others, I cherished at the beginning, has not been accomplished; it has simply been made possible. It remains for those who contended for freedom to apply the larger Christianity thus gained to the great social needs to which it is fitted; and especially to lead out young men who are entering the ministry, who are for this very reason entering the ministry, into those wide and influential relations in which a Christian minister may now stand toward society.

One distinct outcome of recent theological movements, the one outcome in which I am most directly concerned, is the 
creation of the department of Christian Sociology. Your summons, therefore, to the service of the College finds me so far committed to an idea at the time of its opportunity, and to such definite and far-reaching plans for its accomplishment, that I have not been able to assure myself that I could carry over to the administration of the College those first great enthusiasms which are the necessary condition of all noble and effective service.

Beyond this commitment to an idea, to which I have devoted myself, lies my sense of obligation to the institution with which I am connected. It has been, as you are aware, the fortune of Andover Seminary to suffer more severely than other institutions of like character under the dissensions of the past years. The legal difficulties attending the theological controversy are over, and the controversy itself is practically at an end, but the Seminary now needs and demands the most loyal devotion of those who stand for its reconstruction and enlargement. My responsibility to Andover is not only that of an alumnus, but also that of an active participator in the events which have brought about the present condition of affairs. Knowing, as I do, all the facts in reference to the College and the Seminary, I have no hesitancy in saying that the Seminary calls for more arduous service in its behalf for the next years than the College. It would be inappropriate for me to specify in this connection its particular needs, but they are such as to create in the minds of my associates the same sense of obligation which I have avowed for myself. The unity which has thus far characterized our action is not only the expression of loyalty to a common idea, but the acknowledgment of a common obligation to an institution through which that idea has been maintained in courage and sacrifice.

You will allow me to remind you of the advantage which I have had, in considering the question before me, from my knowledge, as a member of the Board, of the condition of the College. According to that knowledge nothing, in my opinion, justifies any fear for its future. The confidence which you have reposed in me by your election, and the general unanimity of 
the friends of the College in accepting your choice, have deeply affected me. Under other personal conditions I should respond to your call with the greatest alacrity - not however because it represents a present necessity, but rather because it represents to my mind a clear and most alluring opportunity. Dartmouth College was never in a better condition to honor any man by its choice. As you well know, the finances of the College are upon a sound basis and its financial prospects are assuring. The Faculty is more complete and represents a higher standard of instruction than at any time in the history of the College. The Alumil have been brought into active participation in the management of its affairs. And the Board of Trustees is, as has been proved by recent acts, thoroughly united and harmonious. Sharing with you the responsibility for the immediate future of the College, I express my confident assurance of its peace and prosperity.

I am, in most respectful acknowledgment of your action as a Board, and in the highest personal esteem to you as my colleagues,

\section{Very sincerely yours}

William Jewett Tucker

Andover, Mass., March 15, 1892

When the decision embodied in this letter had been made and announced, $\mathbf{I}$ began to be aware of the strength of the personal ties which bound me to Andover. I had not been conscious of any undue assertion of sentiment while the question of professional duty was pending. But the decision once made, $I$ began to realize what it would have meant to leave Andover upon such sudden notice. I have refrained thus far from introducing those experiences which center in the home into these professional "Notes." But it is quite impossible to recall the Andover period without referring to experiences in the home within that time, which were vitally related to whatever had gone before in my professional life, and to whatever was to follow. 
In changing from the pastorate to service in connection with an institution, it was naturally to be assumed that there would be much greater permanency of the home. This assumption was justified in regard to residence at Andover by the fact that certain friends of the family and of the Seminary had given the Trustees a fund for building a home for my occupancy. But the house thus provided was hardly occupied before it was consecrated by a great sorrow, the greatest which can fall upon a home - the death of the wife and mother. The death of Mrs. Tucker, though not sudden, was altogether unexpected. It was preceded by a year of declining strength, but it was immediately preceded on the advice of our physicians by a summer in England, which was not without its quiet enjoyments. But she came home only to die, leaving to me the remembrance and the influence of twelve years of a complete companionship reaching into all the aspirations and plans of my early manhood, and leaving upon all those with whom she came into contact the lasting impress of her high spirit and social charm, equally at home and in place in society, and among those needing her sympathy and cheer.

My marriage to Charlotte, daughter of John Rogers, Esq., of Plymouth, New Hampshire, took place on June 22, 1870, in the third year of my pastorate at Manchester, and her death occurred on September 15, 1882, in the third year of our life in Andover. Twice again the Andover home was broken in upon - by the death, ten years apart, of Mr. and Mrs. Jewett, to whom I have had occasion to refer often in terms of filial affection. They had spent their winters with us in New York, and the Andover home was theirs to the end. These three of the family who died at 
Andover have their final resting place in the goodly company of those who lie in the burial place of the Seminary, across the grounds to the east of the home.

Immediately upon the death of Mrs. Tucker, my sister came to Andover from her Brooklyn home to take charge of the young children - Alice Lester, now Mrs. Frank H. Dixon, and Margaret, now Mrs. Nelson P. Brown; and as Mrs. Jewett's health declined, to take the full charge of the household. Her presence brought untold comfort and cheer, and as the years went by, enabled the home to resume much of its wonted hospitality. This most happy service she was able to render for five years, till her marriage to Professor Wells, then of Phillips Academy, and later of Bowdoin and Dartmouth.

Of the renewal of the home, and in the deepest possible sense, of my own life through my marriage to Charlotte, daughter of Dr. Henry T. Cheever, of Worcester, I can hardly write except in terms of the present. But I cannot forget, though thirty-two years have since passed, that it was into the Andover home that she brought those rare gifts of mind and heart which were to make her life so personal and distinctive through the coming years, and yet so unreservedly and so vitally a part of my own; the perfect sincerity underlying the engaging frankness of her manners, the maturity of her understanding and her quick intelligence, her unaffected loyalty to things right and true, her just appreciation of others, and the steadfastness of her personal devotion.

The Andover home gave us Elizabeth Washburn, now Mrs. Frank W. Cushwa, of Exeter, her marriage making the family circle of that generation complete - a family circle now greatly extended and enlivened by the nine 


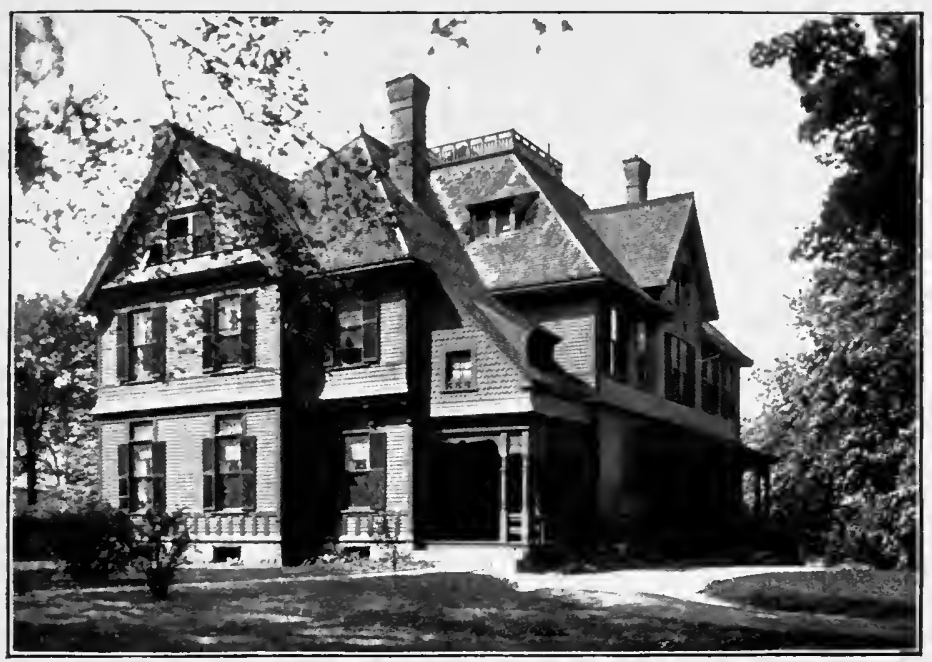

THE TUCKER HOME AT ANDOVER

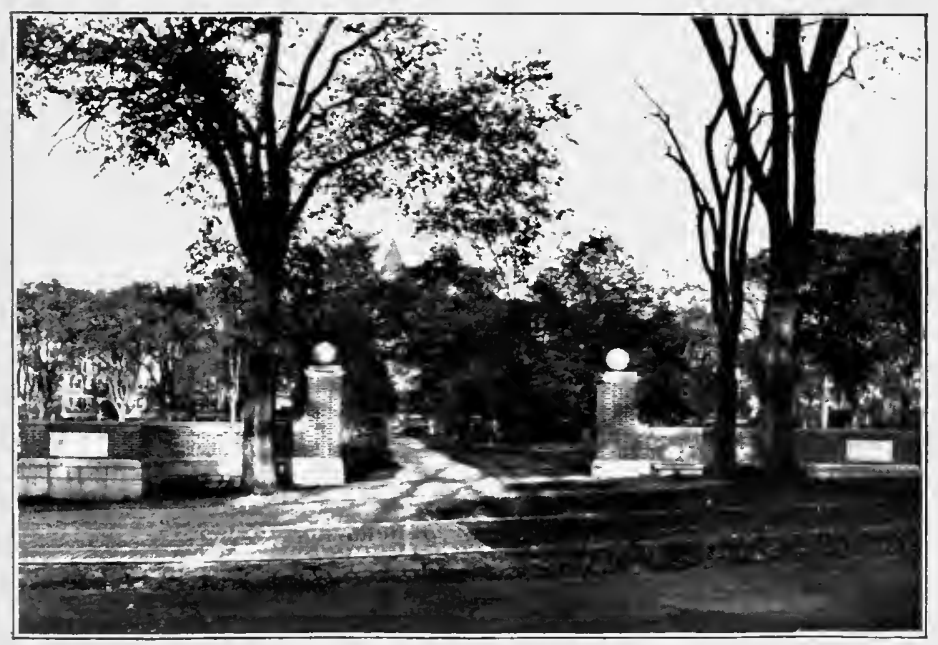

TIIE SEMINARY GROUNDS OPPOSITE THE HOUSE 
grandchildren who throng our home at Christmas and on all intermediate "occasions."

I began this apparent digression into the life of the home during the Andover period, to show reason for the contentment I felt when it appeared to be unnecessary and unwise to break the ties which held me to Andover. But in so doing I have been able, I trust, to reveal something of my sense of the personal indebtedness to those who have been in so large a degree the inspiration and support of my professional life. The Andover home was the meeting-place of sacred memories and of restored hopes, which in their backward and forward reach covered nearly the whole of my professional career.

During the weeks occupied in making the Dartmouth decision, it was impossible to do more than to keep up the routine of the classroom and to carry on one's necessary correspondence.

Meanwhile certain important matters were necessarily laid aside or held in abeyance. I had hoped to give considerable time to the Andover House, which had been opened on the 1st of January at 6 Rollins Street. The work as it had begun to develop under the management of Mr. Woods was most interesting. One could not enter the "House" without being impressed with its object, and infected with the quiet enthusiasm of the residents. It lacked all the characteristics of an institution. The whole atmosphere was personal. It was necessary, however, to interpret the "House" to some whom we wished to identify with it. This necessity called for much correspondence and for a good many interviews. It was pleasant to be able to resume this supporting service in behalf of the "House" while the home life was getting 
under way, and the approach to the neighborhood was being studied and carried on experimentally.

Two other matters of a different nature demanded more urgent attention. In January I had received an invitation to give a course of lectures at the Lowell Institute the following winter, and also an invitation to give the Phi Beta Kappa Oration at the next Harvard Commencement. I had accepted both invitations, not anticipating so serious a draft upon my time and thought as that involved in the Dartmouth decision. The Lowell Institute course was not due till the ensuing winter (the course was actually postponed through the kindness of Mr. Lowell to the succeeding winter), but the preparation of the Phi Beta Kappa Address was urgent. It was my intention in this address to attempt an interpretation of those tendencies which were leading the way into the new social order. I hoped to be able to show the meaning of those ideas which had been gaining force and were gradually being resolved into a single ruling idea The subject of the address as it finally took shape in my mind, was in the form of a generalization, "The New Movement in Humanity-From Liberty to Unity." I was well aware that it is a bold experiment to generalize in the presence of an audience accustomed to close, and for the most part to specialized thinking, but I believed that the timeliness, almost the necessity, of the subject warranted the attempt. As the "Boston Advertiser" remarked editorially on the morning after the delivery of the address - "There was nothing surprising in the choice of such a subject for such an occasion. It was bound to come sooner or later."

To my very great gratification, the address was received by the audience which heard it and later by the press, in 
the spirit in which it was prepared and delivered. It was generally, and I may add in many cases gratefully, regarded as an interpretation of what many were not only thinking but feeling. It may be a sad commentary on present international conditions to quote the remark of Professor H. Grimm, of Berlin, into whose hands the address had fallen, but the remark was not out of keeping with the spirit of the times. He wrote to an American friend in Boston: "I have been reading Professor Tucker's Cambridge address once more and shall probably read it again. ... He expresses in words what many may have felt before, who will now believe that themselves had thought these things first." Even before the War, however, the movement toward unity had been arrested to make a larger place for equality. Of this fact I took account in an article in the "Atlantic" under date of October, 1913, but the thesis first put forth still indicated the working trend of human progress. I think that in spite of the terrible contentions and enmities of the time, unity remains the ruling craving of the world, and that it will appear in due time to be its ultimate goal. ${ }^{1}$

The summer of 1892 was spent at Cushing's Island in Portland Harbor. Rumors reached us early in the season at our various vacation resorts, that a renewal of the "Amended Complaint" was to be made to the Visitors by the remaining complainants. These rumors were later

1 This address, after its quite general publication in the daily and weekly press, was revised for publication in the October number, 1892, - the first issue - of the Harvard Graduates' Magazine, and was later issued in pamphlet form by Houghton, Mifflin \& Company. The address was widely accepted as an exposition of the deeper significance of the social movement, and as such served to give to the movement both consistency and scope. As it is now out of print, this address has been included in The New Reservation of Time- a book of later essays. 
verified, causing further conference and preparation for the renewed attack; but this final action of the complainants was disposed of, as has been shown, by the dismissal of their case by the Visitors before the opening of the academic year. When the Seminary opened in the fall it was free, for the first time in ten years, of the actualities or threats of conflict. A large class presented itself for entrance. The Seminary resumed its work with undivided attention to its normal activities.

In my personal outlook, however, the prospect was not so clear and undisturbed; for it was at this juncture that I began to be made aware of my growing responsibility in Dartmouth affairs. At the meeting of the Dartmouth Trustees following my declination of the presidency, I was appointed chairman of the committee to nominate to the Board a candidate for the position. I knew, of course, that the work of this committee would necessitate much correspondence and general investigation, but $\mathrm{I}$ was to learn only through experience of the various embarrassments and complications which it involved. To make plain the results of my experience, I must refer in some detail to the peculiar situation then existing at Dartmouth growing out of what was known as the "Alumni Movement," the immediate object of which was to secure adequate representation upon the Governing Board. By the terms of its charter, the government of the College was vested in a single and self-perpetuating Board, of twelve members, including the Governor of the State of New Hampshire ex officio. The President of the College became by his election a member of the Board, and by usage its President. The charter provided that eight members should be residents of New Hampshire, and that seven members should 


\section{ANDOVER AND DARTMOUTH 235}

be laymen. This last provision was apparently out of keeping with the usage of the time, but had its probable explanation in the ecclesiastical complications attending the English benefactions at the time of the founding of the College.

Various efforts had been made from time to time to secure direct alumni participation in the government of the College, but it was not a simple matter to gain legal entrance into the Board of Trustees, even by its own consent or through its own coöperation. In 1876 an agreement was made between the Trustees and the Alumni Association by which the Trustees were to allow the alumni to nominate a certain number, from which number the Trustees were to choose three. I was one of the three thus nominated and chosen two years later; but this agreement afforded only temporary relief, as the election in each case was for life and allowed no subsequent choice of the alumni by any system of rotation. The inherent difficulty in every proposed change at all adequate to the demand lay in the fact that it required an amendment to the charter, the suggestion even of which was repugnant to all graduates familiar with the legal history of the College, and imbued with the traditions of the Dartmouth College case. After long and often bitter discussion running through more than one administration, but culminating at the close of the administration of President Bartlett, the matter was amicably settled on the basis of a "gentleman's agreement," in which three parties were concerned - the Trustees, the alumni as a body, and the candidates nominated by the alumni for election by the Board. By this agreement five trustees were to be known as alumni trustees, nominated by the alumni and e'ected 
by the Trustees. In the election by the Trustees no specification of time was made (that would have been contrary to the charter), but each alumnus thus elected pledged himself to the alumni to resign at the end of five years, though eligible for renomination and reëlection. This arrangement virtually put the alumni in control of the College, through the designation of one half of the permanent membership of the Board of Trustees, besides making the Board sensitive to alumni sentiment. ${ }^{1}$

Even with this explanation, one can well understand how difficult it was for any but Dartmouth men to see the importance of the movement which I have described. Its real importance was that it marked a transition in the government of the College involving almost of necessity a change of policy. It at least created an opportunity which conceivably might be unimproved or misimproved. It was the liability that one or the other of these results might follow which increased the anxiety of the friends of the College, as the year wore on without the choice of a president. It was this liability which made the choice increasingly difficult, and added to the anxiety of those who had the matter in charge. The presumption was almost irresistible in favor of the choice of an alumnus, and of one familiar with the history of the College. The man of undeniable fitness in this latter regard, as in all academic ways, was Francis Brown, grandson of the third President and son of Professor Samuel G. Brown - at the time Professor of Hebrew in Union Theological Seminary. The Committee entered at once into correspondence with him, offering him the presidency and urging its acceptance

1 For a clcar and accurate narrative of the struggle for alumni representation on the Dartmouth Board of 'Trustees, see II istory of Dartmouth College' (Professor John K. Lord), vol. II, pp. 378-81, 45j-70. 
upon him. As Professor Brown was then in Oxford, England, engaged in editing a Hebrew lexicon, the correspondence was necessarily protracted, and in the end unsuccessful, not from any lack of loyalty on the part of Professor Brown, but on account of engagements both at Oxford and at Union from which he could not, as he felt, honorably obtain release. The search went on unremittingly throughout the year, but for one reason or another with unsatisfactory results. I could see that my fellow members on the Committee were working with lessening enthusiasm, and I was obliged to confess to myself that I was beginning to feel a lessening confidence in the result. At last in a special meeting of the Committee with the Trustees near the close of the year, one of my colleagues on the Board put to me directly but delicately the question whether the relative positions of Andover and Dartmouth had not so far changed during the year, that the latter now made its appeal to one's courage and sense of chivalry. The question touched the point at which I had become sensitive in my own feelings. I could not altogether put by the disturbing feeling that, as the outcome of my decision was beginning to show, I had chosen the easier rather than the more strenuous course. And the further question became more and more disquieting, namely, whether the apparently plain duty, as determined by personal fitness, must not yield to the duty which was making its persistent demands through the pressure of responsibility. I can also now see, upon reflection, that as I had occasion to make myself more familiar with the problems of academic education, and especially with the aims of undergraduate life, I began to realize the fact that the more specialized purposes which $I$ had sought to 
attain through training for the ministry, might have a broader application in the training of college men. It was becoming more and more evident that the fundamental duties involved in the readjustments of society must be assumed by all the professions, and by men of affairs, some of whom might be expected, under the right incentives, to render a larger and more practical service than the ministry, could the colleges be made to furnish the sufficient motive to the study of the principles of economic justice.

It was no easier to acknowledge than it was to effect the reversal of decision toward which my mind was tending. The change, even in view of the altered situation, seemed to be of that personal character which would not allow one to take the public, hardly indeed his friends, into his confidence. My colleagues at Andover, as they came to understand my feelings, were very generous in their bearing, and acquiesced in the change with varying degrees of assent. The following letter from Judge Bishop, of the Andover Board of Trustees, written after my decision had been announced informally to the members of the Board, is such an illustration of the depth and sincerity of the feeling of my associates, that $I$ cannot refrain from quoting it, in spite of the fact that I could not accept either the professional or personal comparisons which he so generously makes:

Newton Center Jan. 27, 1893

My dear Dr. Tucker:

I am replying too late to your letter, but you know some of the exactions of my life, and with your determination reached, I have not felt the anxiety of a decision to be made which would have impelled a reply at once. 
Looking at the matter now from my point of view, it seems strange to me what a difference there is between the way it appealed to me before, and the way it comes to me now. Before the decision in the former instance, I was strenuous about it in opposition, and should be now if it were an open question; now that it is settled, I have been trying to extract all the good I can from it. I cannot write you such a letter as I ought to write about it. I have just the same feeling of desire that you should stay in Andover, and the same sense of the importance of your staying, but the greatness of the work to which you go appeals to me, and I say that your judgment has been more intelligent than the judgment of any of your friends can be, and has been conscientious and thorough. So, let us all who thought otherwise abide in faith and trust that the right course has been pursued. Above all, it is the guidance of God.

I think your life would be worth little to you, if you were not enlisted with all your powers in a movement; and whether at Andover or at Hanover matters little to the incoming of the Kingdom which the movement serves. In comparison with such a work as yours, I think of the indirect and far off participation which such a calling as mine affords for service in the warfare of righteousness, and am restless. But I know enough about your aims, your insight, and the zest which comes with such a work, to give you my hand and heart in this new development of it.

\section{Faithfully yours}

Robert R. Bishop

The Reverend

William J. Tucker, D.D.

The disposition of the friends of the Seminary was so clearly expressed in the editorial in the "Andover Townsman" following the public announcement of my resignation, that I give it in an accompanying footnote. ${ }^{1}$

1 It is difficult to frame in words the feeling among all who have been brought in contact with Prof. Tucker, whether educationally or socially, at this prospective sundering of ties. The sentiment of pain is doubly poignant, like that of a freshly opened wound, from the circumstance that last year's appre- 
As the reversal of my decision had been fully discussed with both the official Boards concerned, the letter of resignation to the Andover Trustees was quickly followed by the letter of acceptance to the Dartmouth Trustees. The text of each letter is given in full and each supplements the other. I question if these letters were convincing to all who read them in the morning papers of their respective dates, but $I$ do not know that $I$ could at that time have made the issue clearer, or the reason for the reversal of my decision more compelling.

To the Reverend and Honorable the Trustees of Phillips Academy:

Gentlemen - According to the intention, of which you have been apprized, of resigning my chair in the Seminary to accept the Presidency of Dartmouth College, I now present to you my formal resignation to take effect, if agreeable to you, on the first of May. My work for the academic year can then be brought to a close, and, as I am assured, without inconvenience to my colleagues.

The decision through which, with your consent, I thus sever my connection with the Seminary, has been reached only after convincing proofs of personal duty. Each year of my service has bound me more closely to the Seminary by every tie of

hensions were quieted by his declination of the same distinction. Yet all must recognize the cogency of the reasons which he has made public, to justify his change of decision. The Seminary, where for a dozen years he has labored indefatigably and with the utmost popularity, has entered on a new era, free from the agitations and strifes which have long harassed and weakened it. No one of the faculty has more sturdily maintained the central citadel of the Protestant Reformation, "the right of private judgment," than Prof. Tucker, and he would have been the last to retire from the field while danger menaced. Now that peace has been permanently declared, however, he feels free to remove to another arena of activity; and neither his colleagues, nor his admiring students, nor the private friends whom he so largely numbers among our citizens, can interpose an objection when he avers that duty calls him into other work in new relations. They can one and all do no more than voice their disappointment, but with equal unanimity hasten to add their most cordial wishes for his success in the future. Of that there can be no doubt. 
loyalty, of friendship and affection and of enthusiasm for my work. The long period of controversy which has covered almost the entire term of my service, has had its greater compensations in the enlarging sense of spiritual freedom and in the joy of progress. I do not look upon the period as a time of delay or of waste. Still I had hoped and confidently expected that in the years of repose now before us I should be able to enter with my colleagues into the greater opportunities for securing positive results.

It is with reluctance and in deep personal feeling that I put aside the hope and promise of these particular results, or seek to secure their equivalent under other conditions. But that it is my duty to go at the cost of these gains, as at the cost of many personal ties most precious to me, I cannot doubt.

I desire to acknowledge my indebtedness to you for many unofficial acts of kindness and appreciation, and to express my profound sense of the fidelity, the consistency and the courage with which you have administered the affairs of the Seminary.

I am, in the highest esteem

Very respectfully yours

William Jewett TUCKer

Andover, Mass., Feb. 1, 1893

To the Trustees of Dartmouth College:

Gentlemen - The letter of your committee, urging upon me, in your behalf, the reconsideration of my decision in regard to the presidency, is before me. I assure you that I am moved by your continued confidence, as you reaffirm your "original choice" and pledge to me "in case of my acceptance of the office of president the unanimous support of the board and the coöperation of all its members."

And like representations from the faculty and from the executive committee of the alumni touching the present necessities of the College, have made a deep impression on my mind. I may add, however, that my own personal solicitude, under the protracted delay in filling the presidency, has been perhaps as great as that of any concerned for the welfare of the institution. 
You may recall that in declining your election to the office a year since, I said at the close of my letter that "I shared with you the responsibility for the immediate future of the College." These words were written in the full sense of their meaning.

And yet they have meant something quite different from that which I anticipated. I confidently expected that we should be able to avail ourselves of the service of some one of the alumni who had achieved success in educational affairs, or of some one outside of the alumni who could bring to the College a large educational knowledge and experience.

But we have found that those of the alumni to whom we naturally turned were held in their places by reasons so much to their honor that we could not rightly seek to remove them, and we have also found that the present exigency demands increasingly the choice of an alumnus. It has now become as evident to me, as it has been to you, that further delay will seriously imperil the success of the College and thwart its present opportunity.

In the rapid advances which are going on in educational methods, and especially in the adjustment of the traditional college to the broad work of the "higher education," Dartmouth has an immediate and honorable part to take, which, I agree with you in believing, can no longer wait a more extended search on our part for a president.

I am prepared therefore to say, in deference to your judgment, that after the most careful deliberation I am now ready to accede to your renewed request, and to accept the presidency.

Further remark would be unnecessary, had I not emphasized the reasons for declining the office a year ago. The reasons which I then urged still exist, and are in principle the ruling motive of my present as of my former decision. It was institutional loyalty which then held me at Andover; it is the same principle which now sends me to Dartmouth.

Not that the year has wrought violent changes in either institution, but while it has brought greater security and growth to the Seminary, it has left the College in unrelieved suspense and perplexity. One may easily exaggerate his personal value 
to the work of any institution, but when a choice of service is forced upon him, nothing remains to him as a loyal man but to acknowledge the greater need, and to act resolutely upon his conviction.

I obey the present summons to the service of Dartmouth in the same spirit in which I remained at Andover, and in which I would still remain were the relative necessity the same now as then. And as I go I take with me an unabated affection and loyalty to the institution in whose service the most earnest years of my life thus far have been spent.

In like manner I think that it may be rightly assumed that the method and plan of one's life may be changed without surrendering its general or even specific purpose. It seemed to me, as indicated in my former letter, that there were certain great social principles, necessary to the present development of society, which could be better wrought out through the Christian ministry than through any other medium.

I think so still. I believe that the special opportunity to lead the way in social progress which presents itself now to this, now to that calling, lies to-day at the door of the ministry. The opportunity may not extend into the next generation, but it is present and urgent.

Holding this opinion, I have been most reluctant to sever my connection with young men in training for the ministry. But I am aware that adherence to a personal plan or method may be carried to the point of self-will and narrowness, and react upon the very purpose which one is seeking to accomplish.

The particular end which at a given time is best realized through one profession, cannot be remote from any other. Indeed, one of the most helpful signs of the present is the better distribution of the moral responsibilities of learning.

While, therefore, in entering upon the broader work of general education, I shall address myself carefully to educational questions, I shall in no wise lose sight of those more spiritual and human ends toward which the better life of our colleges and universities is advancing.

In my letter of resignation, now in the hands of the trustees 
of the Seminary, I have asked that my former connection with the Seminary may terminate on the 1st of May. If this proposal should meet with their acceptance, as I am already assured that it will suit the convenience of my colleagues, I shall be prepared to enter at that date upon such duties of the presidency as have not been delegated for the time being to Prof. Lord as acting president, under whom the College has been so successfully administered the past year. I shall be prepared to enter upon the full duties of the office upon my inauguration as president at the next commencement. I am, in high esteem toward you as my colleagues, most sincerely yours,

Andover, Mass., Feb. 3, 1893

William Jewett Tucker

The problem of the institutional development of the Seminary had not taken shape when I left Andover. Had such development been under way or even imminent, I might have felt it incumbent upon me to stay and take part in it. It was the misfortune of Andover that its institutional development should have become a problem. In the order of progress, a constructive era should have followed close upon the termination of the controversial period. But the intervening period of financial depletion was so far prolonged that the institutional development when it came, came as a necessity rather than as an opportunity. The difficulty, however, was in the situation; it was really organic. Without an institutional reorganization there could be no adequate institutional leadership. The Faculty had no administrative power. The President of the Faculty had no seat on the Board of Trustees. The Trustees had the twofold duty of administering the affairs of the Academy and of the Seminary. During the long period of conflict which had engaged so closely the attention of the Trustees, the Academy had received an unequal 


\section{ANDOVER AND DARTMOUTH}

share of administrative oversight. It could now justly claim the greater attention. The administration of the Seminary called for economy to meet the indebtedness caused by the long litigation. The immediate demand was for restriction, not for expansion. And when the necessity for constructive effort was urged, there lurked in the background of the discussion the decision of the Supreme Court which had left the Visitors practically undisturbed in their position, though under modified authority. The result of the conflict had not been a gain in institutional freedom corresponding to the gain in theological freedom. It was soon evident that the constructive period must wait for such changes, or such a change in administrative powers, as would allow the exercise of institutional leadership. Time would show the necessity for such a change, but not as it proved till other changes were also seen to be necessary.

For several years the Seminary remained, so far as attendance was concerned, upon the high level on which it was left at the conclusion of the controversy. When the institutional development which had been assumed failed to take place, the decline in numbers began, and this decline gave rise to the vexing question of removal. There had been for some time a latent desire on the part of some members of the Faculty to remove to Cambridge, and effect a definite if not organic relation with Harvard University. This desire was in accord with the general trend of the professional schools toward a closer affiliation with the Universities. The removal of Mansfield College to Oxford had indicated the institutional tendency of theological education in England.

I was frequently asked to express my opinion as an 
alumnus on the question of removal from Andover. To these requests, I declined to make answer, because it would have been an unseemly thing for me to take part in a matter to which $I$ had no longer any responsible relation, and also because, as I did not hesitate to say, the supreme question seemed to me to be not that of the removal of the Seminary, but that of the creation of a Board exclusively concerned with the affairs of the Seminary, to which this and all like matters could be referred. The creation of a separate Board for exclusive attention to the Seminary was happily brought about by legislative action, resulting in most beneficial effects upon the Academy, and as I doubt not will appear in due time upon the Seminary. Had I expressed the private opinion which $\mathbf{I}$ then held upon the question of locality $I$ should have advocated removal, but removal to Boston instead of Cambridge. It seemed to me that a seminary of the assured traditions of Andover for scholarship, would find a more needed stimulus in the atmosphere of the city than in the atmosphere of the University. A theological school seems to have more difficulty in maintaining its distinctive professional aims under the diverting influences of a university than a law school or a medical school. The catalogues of these various schools are in evidence at this point. As compared with his fellow student in law or medicine, the theological student is more sensitive to the lure of the purely academic. Where the professional stage of education is reached, I believe that education must become definitely and aggressively set toward the specific end of a given profession. And unless there has been some deficiency in the academic training of a student of theology, he cannot concentrate too resolutely upon his essential 


\section{ANDOVER AND DARTMOUTH 247}

business. But the expression of this opinion has now no pertinency, unless it be in the general interest of more distinctively professional training for the ministry. I have accepted in good faith the decision of the new Andover trustees to remove to Cambridge, and to build up Andover in the new environment. 


\section{CHAPTER IX}

\section{The Dartmouth Period 1893-1909}

MODERNIZING AN HISTORIC COLLEGE

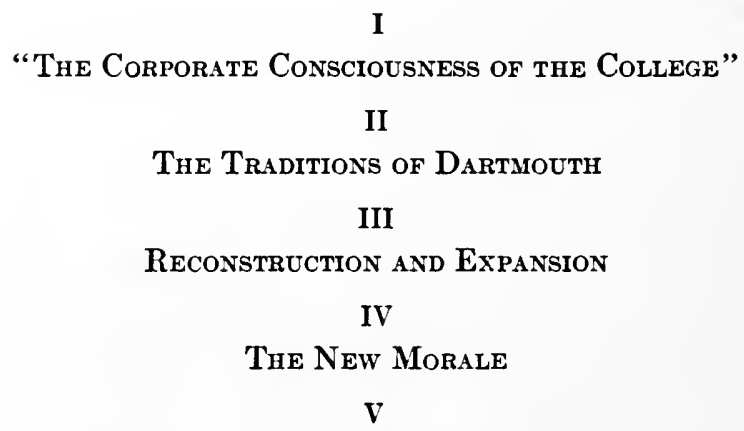

An Advanced Policy Toward Non-Professional Graduates VI

Professional and Peblic Relations dering the Presidency VII Two Years of Crippled Leadership 


\section{CHAPTER IX}

\section{THE DARTMOUTH PERIOD}

I

"The Corporate Consciousness of the College"

BEFORE entering upon the course of the College administration at Dartmouth, I discuss briefly the general but underlying subject of the institutional life of a college. This inner life of a college viewed as an institution, its institutional spirit, is called in the quotation placed at the head of this section "the corporate consciousness of the college." As such it is the most vital and the most sensitive element in its effect upon college administration. It may make itself felt in ways which are most perplexing, but it may also be made use of for large and timely result. In any event it is an ever present force, never to be ignored and never to be neglected.

Our American colleges and universities are, in a peculiar and most significant sense, institutions. They represent more distinctly and more impressively than anything else the institutional life of the country. Some of them were chartered before the organization of the Government. The charters of all, at whatever period granted, or whether conferred on private or public foundation, breathe the same spirit. They are more than charters of rights. They try to express in various ways the public interest, a sense of the social necessity for which they would provide, the obligation of the State to the higher education. These chartered obligations are generously supported by public or private benefactions. Gifts are quickly transmuted into 
sentiment. Interest develops into pride. Colleges and universities absorb very much of the public feeling which finds expression in the attitude of the people toward the establishments of the Old World. In the absence of the ceremonials of a State Church, the academic ceremonial is the most impressive of all public displays, and is likely to so remain, unless we become a military nation.

It is not difficult to explain the place which the college or university holds in public sentiment. It stands far in advance among the things which have a recognized spiritual value, using the term in its broad meaning. The substance of the college does not consist primarily in the popular estimation in its physical properties, or even in its curriculum, but in its idealism. It is the institutional spirit which gives public value to an academic institution. A college administrator is expected to be more than a financier, more than a schoolmaster. He must embody in some tangible and expressive way "the corporate consciousness of the college."

Before making further use of this quotation, I will give its connection. It is taken from a communication by Dr. Kirsopp Lake to the "Harvard Quarterly," after attending his first Commencement at Harvard, 1914. This characterization of the spirit of the American college is very striking and very significant as rendered by so eminent an academic authority. Such an interpretation could not have been given by one less versed in the genius of the earlier and later European universities.

If we compare [he says] Harvard Commencement with the Dies of a Dutch University, or even with Commemoration at Oxford, two things emerge as representing points in which the American college of to-day has an advantage over anything 
which exists in Europe at the present time; and the historical imagination is reminded by them of the Middle Ages when the great universities of the old world were in the full power of their youth. These things are the consciousness of the Alumni of their membership in the University, and the spirit of religion - in the real sense of the word - which inspires the corporate consciousness of the College. The college man seems impressed to a wonderful extent with a lively sense that he has been called with a great vocation. To most of them this is much more vivid than the feeling that they have received some sort of teaching which will be useful to them in their personal careers. . . . So it was in the Middle Ages. . . . The college men of to-day can rarely speak or understand the language of the Middle Ages, but they seem often to have been "stung by the splendor" of the same thought as inflamed the hearts of the men of those days.

It is not necessary that one be versed in mediæval customs, or possessed in high degree of the historical imagination, to understand Dr. Lake's interpretation of the spirit of the American college. According to this interpretation, it is the distinction of the college that it creates a "corporate consciousness," which in turn is capable of creating in the college man " a lively sense that he has been called with a great vocation." When the college man of to-day really enters into this consciousness, and is really touched by the sense of the vocation with which he has been called, he is "stung by the splendor" of the same thought that inflamed the hearts of the men of the Middle Ages.

Although this exposition of the more spiritual type of American academic life is heightened somewhat by the historic imagination of the writer, it is in essential harmony with the view of the idealistic school of our own educators. In their view, the college stands for more than finds expression in any technical or cultural output. It represents 
also in high degree the play of those deeper human forces which have such freedom and scope in the whole range of human life. In 1909, at the Inauguration of President Nichols at Dartmouth, Woodrow Wilson, then President of Princeton, gave an address in which he made the following acknowledgment of the real nature of our academic communities. The address was given before representatives from all the leading colleges and universities of the country, and evidently met with their approval.

I have been thinking, as I sat here to-night, how little, except in coloring and superficial lines, a body of men like this differs from a body of undergraduates. You have only to look at a body of men like this long enough to see the mask of years fall off and the spirit of the younger days show forth, and the spirit which lies behind the mask is not an intellectual spirit: it is an emotional spirit.

It seems to me that the great power of the world - namely, its emotional power - is better expressed in a college gathering than in any other gathering. We speak of this as an age in which mind is monarch, but I take it for granted that, if that is true, mind is one of those modern monarchs who reign but do not govern. As a matter of fact, the world is governed in every generation by a great House of Commons made up of the passions; and we can only be careful to see to it that the handsome passions are in the majority.

A college body represents a passion, a very handsome passion, to which we should seek to give greater and greater force as the generations go by - a passion not so much individual as social, a passion for the things which live, for the things which enlighten, for the things which bind men together in unselfish companies. The love of men for their college is a very ennobling love, because it is a love which expresses itself in so organic a way, and which delights to give as a token of its affection for its alma mater some of those eternal, intangible gifts which are expressed only in the spirits of men. 
While, however, the institutional spirit which pervades our colleges is recognized by all, and accepted by most as vitally inherent, it is looked upon by not a few as dangerous in its tendencies, and in its more extreme forms subversive of the highest ends of college training. I take note of the essential criticisms. The most common and perhaps most pertinent criticism is to the effect that the institutional spirit is institutional rather than educational, and may become positively anti-educational. One critic writing in a book review in the "Nation" declares flatly, "As long as loyalty to college is considered a virtue, you will get little loyalty to college education. They are unalterably opposed. Students cannot be taught to think while their minds are glued together. Shatter the virtue of loyalty to your college and in your college and you have neutralized the centripetal force which draws the man to a mediocre norm." And still more definitely an editorial in the "Seven Arts" affirms that the American colleges, as regards the literary interests of the country, and especially the women's colleges, are not sending forth anything like the number of creative workers that would be expected of them. Of one woman's college in particular "write me for the name if you wish" - of the very highest standing, which has sent forth some thousands of graduates and post graduates, not one of them has ever entered upon any creative or artistic labor.

I am not blind to the conditions which from time to time give rise to strictures like these, nor do I overlook the element of truth in the general criticism of which these are fragments. Nevertheless I believe that all such criticism is based upon a misconception of the function of the college in the educational system. It is not the supreme 
office of education at the period covered by the college to develop the individuality of the student, but rather his humanity, using this term in its strict educational sense. In this sense it is more desirable that a college student shall be thoroughly humanized than that he shall be prematurely individualized. The humanizing process consists in the introduction of mind to mind under mutually stimulating conditions, in the give and take of the physical and intellectual life, in the stimulus of competition, in the sense of comradeship in the intellectual adventure into life. Exception to the value of this process is to be taken in favor of the well defined artistic temperament. I doubt if our colleges have much to offer to the must-be artist or even to the would-be artist. Tennyson said that he got nothing from Cambridge; and yet Cambridge had doubtless far more to offer to an incipient poet than to one born with an equal aptitude for the other so-called fine arts. The distinction appears when one contrasts the college experience of Tennyson with that of most of the great parliamentary orators. Apart, however, from those of the artistic temperament whom the college can seldom reach to advantage, there are those, very few in comparison, who can profit at once by the individualizing process. They are ready for contact, not with or through others, but altogether by themselves with those high and separating subjects which lie within the range of college study; and for their ambitions and capacities provision should be made. An unsatisfied seeker after truth of any kind, who outruns his fellows but finds no welcoming companionship among teachers and guides, is a sad sight. I repeat the necessity for provision for the man of exceptional individuality in our colleges. But this type of student 
does not constitute the problem of college training. The concern for individuality usually expresses itself in some undue concession to a partial or prematurely specialized talent, with the result to the individuals so treated that they are intellectually stranded in later life; they fail to make connection with men and with events. They are not for the most part those who best meet the tests of the professional schools, or even of the specialized graduate school. Experience has shown beyond dispute that the higher education at the college stage is best mediated through institutions; and the institutional process is not set directly to the task of individualizing the student mind.

It by no means follows, however, that the principle of associated life and activity upon which the college rests, cannot be made a stimulus to personal effort in scholarship, in some respects the most powerful which can be applied. I believe that there are incentives and compulsions in the spirit of a college which have not as yet been put to the highest uses. College sentiment has left scholarship too much to the individual. But the individual impulse to scholarship has not proved strong enough in the average student to reach any high result. The scholar of the individua'istic type, whether such by instinct or by persistent habit, is a comparatively rare person. Accepting Phi Beta Kappa rank as the minimum standard of actual scholarship, it would not be possible to assign more than one fifth of an ordinary college class to this rank, and of the number included in this proportion probably one half should be rated as diligent students rather than as scholars. But there are very many men in the colleges who are capable of reaching the results which can be gained only through scholarship, and who may be expected to reach 
these results, provided it can be made clear to them that scholarship is one of those indisputable things which a college expects a man to contribute as his part in the discharge of the common obligation. The spur of competition is purely individualistic. The sense of accountability is part of the social sense. It may be incorporated into the spirit of a college and applied where the stimulus is most needed. To-day the men who most need this special stimulus are the strong and capable men who are in danger of making a miscalculation in regard to college values. From the strictly individualistic point of view, the investment of power in scholarship may not seem to them to be the most profitable investment. Let the question be changed. Is there any other investment of power, open to a college student, so profitable to his college, so profitable to his country?

In view of the failure of the purely individualistic appeal for scholarship, I believe that the appeal should be urged increasingly through the institutional or "corporate" spirit of the colleges. This appeal is wider and more undeniable. The really significant task of the college is to make the strong and capable men under its training realize in time the social value of scholarship. Devices for quickening the lazy, or for helping the weak, are mere matters of college discipline. The rescue of a strong man from the misuse, or from the under-use of his power, is the most satisfying and usually the most rewarding of all college endeavor. Every such man, who takes on the habit of mind of the scholar, gives reality and incentive to the pursuit of scholarship. He brings the spirit of the college to bear upon the issue. I am well aware that the tradition of the American college does not point the way to indi- 
vidualistic scholarship. Dr. Lake intimates as much in regard to the university of the Middle Ages. The "Saturday Review" has made a like admission in regard to the English universities: "The main intention of Oxford and Cambridge is not even scholarship and high thinking, though without these we truly believe that the nation will perish. Their main intention is to encourage a spirit among the young men of England which will make them instinctively conscious of a call to account very strictly to the world for such talent or power as a man may have."

This exposition of the ground and motive of English scholarship, including the honor system, is worthy of special note, for it discloses the normal appeal of the college in behalf of scholarship. The appeal is frankly and broadly human, not individualistic. It may seem more distinctly moral than intellectual. I think that it is; but for that very reason it reaches most directly and most effectively "the mind of the college."

Another criticism, less significant but not to be overlooked, is to the effect that the institutional spirit tends to provincialism. It unduly magnifies the small college. It detaches the academic from the public mind.

The danger to the small college from provincialism is obvious. The small college creates a certain intensity of view which is supported by an equal intensity of character. But in this concentration of institutional life there may lie, and usually does lie, a degree of intellectual and moral force quite out of proportion to numerical size or to financial resources. What Mr. Bryce has said in regard to the small nations applies with like reasoning to the small colleges. In fact he has made the application of his thought to them. The struggle incident to poverty, the extra effort 
required to counterbalance the lack of abundant instruction or equipment, often the remoteness from stimulating associations, which necessitates the larger use of selfcontained powers, seem to produce a type of academic character of marked value to the public life of the country, and not infrequently of striking originality. The determination of the representative small college to reach and maintain the academic standard is proof of the enlarging effect of its institutional spirit. In place of expansion, there is often noticeable a remarkable insistence upon technical standards. The small college may be small under temporary restricting conditions, but it is usually intent upon making connection with the standardized academic system. There was more than humor in the reported saying of the director of a small railroad, who wanted to connect with the New York Central in the days of Commodore Vanderbilt. To the rather contemptuous question of the Commodore, "How long is your little road?" he had the ready answer, "What does that matter? It's just as wide as yours is." Underneath the humor of the situation and apparent to the Commodore, was the essential fact about the road - it could connect, it had the standard gauge.

Of the assumed detachment of the academic from the public mind, it is hardly necessary to make serious mention at the time I am now writing. The American college has never stood in the public esteem for pedantry, but there have been times when it has borne the burden of its so-called inutilities. Those times were past even before the events preceding the War. The college curriculum turned more and more toward affairs. College men met in the theories of the classroom many of the scientific 
and economic problems of business and industrialism, before they were confronted by them in their practical details. Since the Government has laid its hand upon all available constructive or executive talent in the country, Washington has become the meeting place on equal terms of the business manager and the academic expert. Perhaps no discovery has been more agreeable to the public than the practical capacity of the non-expert members of the college faculties. The appointment, for example, of the Professor of Classical Philology at Dartmouth as the Executive Secretary of the Council of National Defense for New Hampshire has been in no way exceptional.

I do not know of any present detachment of the academic from the public mind of sufficient account to invite criticism, unless it may be found under the guise of a cult which is coming to be known as "intellectualism." The term itself, when relieved of its aspirations to superiority, stands for a legitimate and fine expression of the academic mind at its best - the absence of prejudice and sentimentality, freedom from partisanship, moral as well as intellectual independence, a certain high and undaunted spirit of adventure, and above all, loyalty to the pure light of reason. The present affectation of the term is by no means a distinctive academic vice. "Intellectuals" so-called or self-styled are much in evidence. There is a very considerable appropriation of the name to identify those who hold "advanced" positions on the shifting intellectual frontier, and who represent to themselves and to those likeminded some fancied enlightenment. In some cases, they belie the name they assume by advocating theories charged with sentiment rather than informed by reason. The craving for the intellectual thrill is simply intellectual 
emotionalism. Unfortunately, the academic mind is not altogether proof against this new style of intellectual provincialism, but I doubt if it will long survive in our colleges and universities, where the natural and free expression of the intellectual life is fatal, in time, to all affectations or assumptions of superiority.

The most serious criticism, amounting at times to a charge in the case of some specified college, is that colleges as institutions are subject to the dangers and evils of institutionalism. It cannot be denied that the charge in some form has occasional justification, or that there are constant liabilities in the institutional development of colleges. But it is on the whole remarkable that the progress of collegiate education has shown so few examples of well defined institutionalism. Corrective tendencies have been continually at work from within, and often corrective measures have been applied with breadth and courage. I recall some of the greater dangers and the means of escape or of prevention. This review is confined to the independent colleges and universities. The liabilities of the state colleges and universities are for the most part of a different sort.

It must be confessed that it was a dangerous experiment to entrust arbitrary power (under charter limitations) in perpetuity to a self-perpetuating body. But the founders of the early colleges followed without hesitation the usage of their time. Extraordinary powers were conferred upon the corporate members, involving not only the control of all properties, but the sole authority to elect, and if deemed necessary "to displace or discharge" any or all officers of instruction and government. It is to the credit and honor of the public sense of integrity and justice which then ob- 
tained, that so dangerous a system could be carried on for one or more centuries with so little friction, or miscarriage of justice, or loss of self-respect among those under authority. It is still further to the credit of these selfperpetuating Boards of Control that they have so far relinquished voluntarily such exclusive exercise of these arbitrary powers as they have been able to divest themselves of, without violation of their chartered obligations. The transfer within the last generation to so large a degree, of the governing function of the colleges to their alumni, through the device of alumni representation, has done very much to insure the liberality and freedom of college government. There remains, however, the question of the complete and responsible adjustment of faculties to college administration. The advance in the recognition of faculty rights, both of individuals and of the general body, has been very marked. It now seems to be in the way of reaching at least a working adjustment. But the question of rights is really subordinate to that of responsibilities, and no satisfactory solution of this question is yet in view. In consequence the present relation of faculties to governing boards is unseemly. It rests upon the basis of separate and of possible antagonistic interests. Professors' "unions" exist for defensive, or possibly aggressive purposes. They recognize the principle of "class consciousness." They organize the professional element in academic life against the already organized institutional element. Doubtless this state of things brings about, as I have said, for the time being a practical working adjustment, but from the nature of the case it cannot be permanent. The question of rights, that is, should not be allowed to settle into the most sensitive question connected with college 
administration. The only proper question which can be associated in any form with administration is that of personal or official responsibility. To bring the status of professors up to this level the initiative must be taken by the body which now holds the ultimate responsibility. It is confessedly a greater problem to incorporate faculties into the responsibilities of administration than it was to incorporate alumni into that particular relation, for the question of professional rights is not involved in the case of the latter. But the problem is in no sense insoluble. And whenever a suitable way is found to confer upon faculties a fair share of the rights of responsibility for the general government of colleges, I believe that contention for all other rights real or assumed will cease to vex the academic world. There can be no possible academic freedom beyond that which is implicit in academic responsibility.

The colonial, and in general the historic, colleges have either escaped or outgrown the dangers of ecclesiastical institutionalism. I think that this is more remarkable than that they should have been able to relax the grasp of the close corporation. The religious motive was so dominant at the outset, and the ecclesiastical environment so close, that a different result might have been expected. And yet it must be remembered that great as was the hold of religious authority there was very great jealousy in behalf of religious freedom. Dartmouth, so far as I recall, owing to reasons already stated, was the only one of the earlier colleges to prescribe that the majority of the governing Board should be laymen, but the guarantee of religious toleration was inserted in all the charters of the contemporary colleges, and was usually set forth in very explicit terms. The tending away from ecclesiasti- 
cism has been one of the marked features of academic development. Of the early colleges which had their origin in denominational enterprise all now report themselves as "non-sectarian" unless required by their charters to maintain the original denominational control. And in the case of these few colleges, it should be remarked that for the very reason of nominal sectarian control, they take unusual pains to make their actual non-sectarianism evident. Sectarianism is a characteristic of the newer colleges which must for the time rely upon denominational support for their existence. Their sectarianism does not represent the spirit of propaganda. In due time these colleges will doubtless become non-sectarian in the same way in which the older colleges of like religious origin have passed into that estate. It is seen that sectarianism does not conduce to academic religion. Traditions may be cherished, forms of worship preserved, and the spirit of the inherited faith guarded, but academic religion must have freedom and breadth. And these qualities are practically insured in the religious life of all colleges. Whatever difficulties the religious problem may present in college administration, the essential difficulty does not arise out of sectarianism or ecclesiasticism.

The danger that the colleges and universities may become "institutionalized" through wealth is yet to be tested. The liability of such a result is comparatively recent. The foundations of great endowment at the outset, like Leland Stanford and the University of Chicago, fall practically within the twentieth century. Johns Hopkins led the way (in 1876) among the institutions highly endowed at the start, with its relatively modest foundation of $\$ 3,000,000$. Harvard, still the wealthiest 
among the universities, with the possible exception of Columbia, at a present valuation of $\$ 34,000,000$ in productive endowments, was rated at $\$ 5,000,000$ in 1889 . The advance of Yale from less than $\$ 1,000,000$ at that date to over $\$ 21,000,000$ at the present time is perhaps the most rapid of any. The era of great endowments falls within the last three decades. Previous to 1890, the amount of productive funds held by all of the New England colleges and universities was less than \$12,000,000; the present amount is about $\$ 100,000,000$.

This increase in the holdings of the colleges and universities has been so rapid that any moral result is concealed in the very process of acquisition. We speak of the expansion of the colleges, but hardly as yet of their capitalization. But the time is not far off when this recent development must be considered in its educational tendencies and effects. Some of our educational institutions under private endowment have already become in a subsidiary way very considerable financial institutions.

There are two tendencies in the financial development of colleges and universities which are already sufficiently noticeable to suggest the need of more watchful observation. First, the tendency to transform the governing Boards into financial boards. With the rapid increase of endowments this result is inevitable - at least to the extent of insuring their proper care. The finances of a college must be wisely administered, and in these days few men apart from financiers are capable of making suitable investments. But the indirect effect of this change in the personnel of the governing boards is to make the alumni and other friends of a college think of this new obligation as their chief function. The criticism has 
already been passed upon the nominations made by the alumni of some of our universities, that they represent bankers quite out of proportion to educators, - a criticism which recalls the question, partially discussed, as to the further responsible use which can be made of faculties in shaping the policy of the college. The educational and financial policies are really inseparable. It is doubtful if the demands of the educational can be met through delegated powers. To repeat what I have already said, I think that the way must be found to satisfy both of these responsibilities through one and the same board, as was practically the case before the financial responsibility assumed such large proportions.

A second tendency is to be seen in the growing reliance of some colleges upon educational boards of trust for financial aid. Probably most colleges which allow themselves this use of what may be termed professional financial aid would regard the use as altogether exceptional, to be accepted in an emergency, or to be employed as a stimulus toward raising some large fund. But some colleges seem to be acquiring the habit of such reliance. These boards of trust are assumed to be free from all controlling influences over the colleges. It would seem difficult, however, to dissociate influence altogether from money given in large amount, or in repeated benefaction. The introduction of the boards of financial aid into the educational system, with large capital and highly organized, is an innovation upon the financial method of the self-governing colleges.

It should be said that the Carnegie Pension Fund (Foundation for the Advancement of Teaching) has a partial justification in this regard in the fact that it is so 
largely under the control of representatives of the colleges and universities which are the objects of its beneficence. But I think that it was a relief to many when it was proposed to operate the fund on an insurance basis, after being released from present obligations. I felt that Dr. Pritchett deserved great credit for the courage and sagacity involved in this proposal. When the question of applying to the Carnegie Foundation was before the Dartmouth Trustees, I did not vote for the application, but I did not oppose it, as I was just leaving the presidency, and could not mature the plan which I was devising as a substitute. I also hesitated to oppose it because I had reason to believe that a general pension fund would be more agreeable to some of the faculty than a college pension fund. But I regretted none the less the enrollment of the College among the beneficiaries of the Fund. I thought it a matter of honorable congratulation that the Trustees of Brown were necessitated by the charter of the university to forego this aid, and to maintain at this particular point, though at much cost, their entire financial independence.

The plain fact is, that it is just because our colleges and universities are institutions, that they have the liabilities which belong to all such reservoirs of power. They must be guarded from the dangers which inhere in their constantly augmenting strength. Hence in college administration there is as much need of moral sensitiveness as of intellectual alertness. But the greater danger to our colleges and universities does not lie in any tendencies to their misuse as educational institutions, but rather in the constant temptation to their insufficient or inferior use. The 
emphasis may fall upon the wrong place or be suffered to rest too long in what had been the right place; a timely intellectual or moral enthusiasm may not be carried to a legitimate result; the opportunity may be allowed to pass for the sure conservation of institutional power through its expansion. The function of the university, for examp!e, in its relation to the past has been defined as consisting in providing "the means by which the highest culture of one generation is best transmitted to the ablest youth of the next." This, it seems to me, is an insufficient interpretation of the relation of a university to the past, and one which has often given barren results. The great obligation of the past is not the transmission of its culture, but the transmission of its creative spirit, which may find as an imperative duty the task of recreating its culture, which in turn may necessitate the destroying of more than it may preserve. In like manner the attempt to utilize college enthusiasm may go no further than to arouse "college spirit"; it may utterly fail to develop that fine esprit de corps which, as Mr. Wilson says, is the product of the "handsome passions," that in their free play can alone guarantee nobility of thought and action. Or still further, an institution may subject itself to the humiliation of intellectual loss, or to the chagrin consequent upon any sense of intellectual waste, when it is unable to put a right valuation upon the new subject-matter of the higher education, or is unable to organize it into the "college discipline."

I am aware that what I am now writing may seem like reflections growing out of the experience of the years of college administration. Doubtless the feeling which pervades these words is enhanced by my experiences and 
observations. But it was the very sentiment regarding the institutional life of a college which I am now expressing, that was the convincing and assuring motive in my acceptance of the Dartmouth presidency. The "situation" with its risks and possibilities was as clear then as it now appears in retrospect. Viewed in the light of institutional possibilities the opportunity was plain, albeit a venture of faith. Professor Foster, head of the department of history, has told me that about the time of the close of my administration he called, in an examination on the colonial period, for a comparison between the early history of the college and its latest development. One student remarked incidentally, comparing Dr. Wheelock and myself, that both "were gamblers by instinct." I was as much pleased as amused with the insight of the student. Dr. Wheelock certainly took, according to the view of the average man, a great chance when he ventured on his errand into this northern wilderness. My errand was undertaken under very different conditions, but measured by the definite object to be achieved which was to determine its success or failure, this latter venture of faith had in it to the ordinary, and to the interested onlooker, a large element of chance. This object was nothing less than to attempt to give to the College its possible institutional development - to develop it to its full institutional capacity. The colleges with which Dartmouth had been most intimately associated in its early history Harvard, Yale, and Princeton - had gradually drawn away in the pursuit of their own educational ideals. Harvard and Yale had already defined themselves as universities, and Princeton was taking steps to reach the same end. What further development should Dartmouth at- 
tempt, consistent with its traditions, and possible of realization? No alumnus of Dartmouth cherished the desire to see the College become a university. Apart from the adverse sentiment which the attempt of the State (in the Dartmouth College controversy), to convert the College into a university had created, it was clearly seen that the limitations of its environment would make the attempt, so far as any satisfactory result might be concerned, quite impracticable. But the purpose was legitimate and practicable, and the opportunity was present, for Dartmouth to expand and to seek to fill to the full the college ideal. This was the purpose entertained, altogether distinct from the ambition to realize the university ideal, but in itself honorable, and satisfying.

The means for carrying out this purpose, so far as they fell within the province of administration, were both moral and material. To my mind the emphasis in the choice of means rested at three points. First, Dartmouth was in a peculiar sense an historic college. Its history was its great asset, both moral and material. It was necessary that its history should be capitalized at its full value. To this end the College of the present was to be brought into vital contact with the College in its origin and early development. The essential thing was to open wide the channel for the transmission of the spirit of the College. Dartmouth had no advantage in the transmission of culture. Her advantage, and it was very great, was in the well-nigh unrivaled possession of an originating spirit at once creative, adventurous, and charged with spiritual power. The significance of this heritage will appear in the succeeding section of this chapter.

Second, the creation of a high college sentiment, not 
mere college spirit, was essential to the full institutional development of the College. I have placed much stress upon the educational value of the human element during the college stage. It is of special value in creating the institutional spirit in constructive periods. "The mind of the college" can be lifted at such times above the ordinary causes of enthusiasm and set upon the growths and advancements of the college itself. Such periods produce a fine community of feeling among members of the faculty, students, and alumni. The institutional effect of growth in numbers is not to be minimized, but the real significance of numbers lies in what they represent. Assuming quality as a fixed necessity, the most desirable result is the broadening of the constituency of a college. In the present case, the object sought in the increase of the student body was the nationalization of Dartmouth.

The third point upon which emphasis was placed was that any plan of reconstruction and expansion must be commensurate with the existing opportunity. This as compared with those already mentioned was the material point, but it involved the whole question of educational advance. The contrast is often drawn between teaching and equipment to the disparagement of the latter. There may be reason for this disparaging contrast, but it was entirely out of place in that period of educational reconstruction which followed the introduction of the sciences and of the scientific method. Teaching became in large degree a question of equipment. Colleges had to be rebuilt. The college plant had an educational value which no instructor could despise. No increase of salary could make amends for meager facilities. Such was the situation at Dartmouth at the beginning of the period of recon- 
struction and expansion. It was altogether an educational crisis. Next to a spirit of hospitality toward the new subject-matter of the higher education was the necessity of making adequate provision for it; and this demand, when met, necessitated in turn the rehabilitation of the material of the older discipline.

I will not anticipate what is to be said more in detail as I describe the modernizing process which went on at Dartmouth, but I may fitly say at this point that I quickly became aware of the dynamic force latent in the College, as I sought to bring it up to its full institutional capacity, and I may repeat what I have already strongly urged, that college administration has to do with spiritual quite as much as with material forces. The college administrator, whatever may be his other qualifications, must be able to recognize the meaning and to feel the force of the "corporate consciousness of the college."

\section{II}

\section{The Traditions of Dartmouth}

"I would have an Inscription over the door of your Building - Founded by Eleazar Wheelock: Re-founded by Daniel Webster." Judge Hopkinson to President Brown in a letter announcing the decision of the Supreme Court in the Dartmouth College Case. (Inscribed on Webster Hall.)

In contrast with the educational foundations of the latter half of the nineteenth century established under the stimulus of the scientific spirit, those of the eighteenth century seem to have been dominated by other than strictly educational motives. The dominating influences of this century were religious and political. Dartmouth differed in no wise from the colleges of this or an earlier date in respect to the general influences affecting the higher education, but it differed from them widely in the cir- 
cumstances in which these influences were operative. The religious motive not only acted with peculiar intensity in the inception of Dartmouth, but it gave to the movement a certain adventurous character. Dartmouth was by distinction a pioneer college - a religious venture into an untried field of education as well as into a remote region. All the other colleges were within or near the existing centers of population.

Dartmouth was "a voice crying in the wilderness" to the denizens of the wilderness. But it was because of this separateness of object and remoteness of place that its "voice" was heard so far off - in the streets of London, in the churches throughout Great Britain, at the court of the king. The fortune of Wheelock's Indian School, the incipient college, bearing with it the fortune of the indomitable and intrepid Wheelock, constitutes "the romance of Dartmouth." It gave, as I have said, to the founding of the College the character of religious adventure; and as such it stamped upon the College the mark of the adventurous quite as much as of the religious. Dartmouth has not retained above other colleges of its generation the religious spirit, but it has retained I think some of the distinctive characteristics of its adventurous origin.

Dartmouth differed from the other colleges in another very important circumstance. Within fifty years from its founding it was obliged to pass through a struggle for its legal existence. The reëstablishment of its chartered rights which had been in jeopardy, has been fitly termed its refounding. The circumstance attending the refounding was altogether of another character from that attending its founding, and produced an entirely different effect. It marked the sharp transition from a religious to a legal 


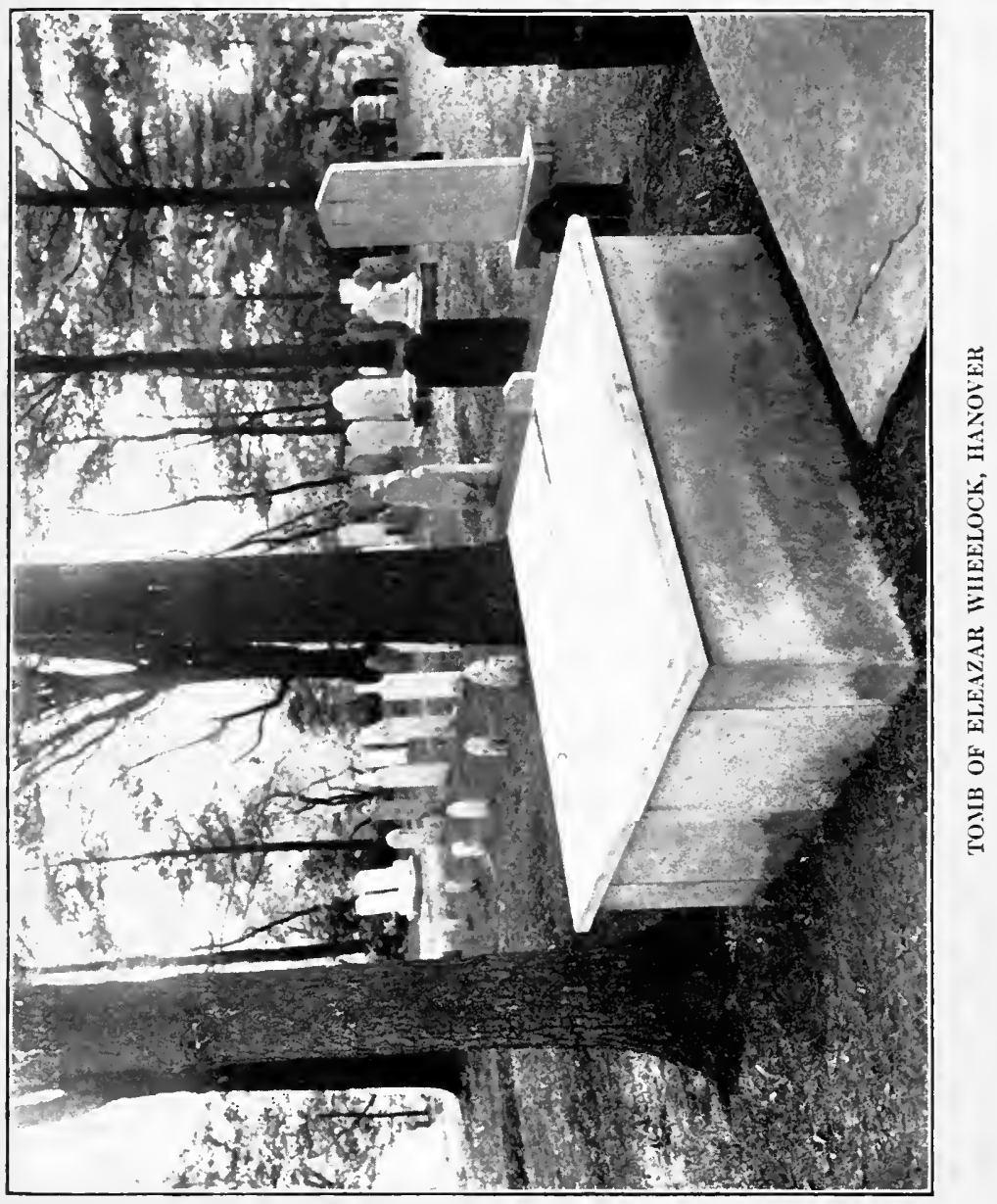



environment. It is difficult to estimate which circumstance had the greater effect upon the institutional life of the College. But the influence of the latter circumstance was no more strictly educational than that of the former. The legal contention brought the College into close relation to the various chartered interests of the country, not only educational but to those involving property rights. It served to nationalize the College. And it added, not immediately but in due time, the reputation of $\mathrm{Mr}$. Webster to its vital assets.

The founding and the refounding of Dartmouth are in themselves events of such unusual interest in the history of educational foundations, they represent such diverse influences, and they are associated with men so wide apart as Wheelock and Webster, but of such unusual quality and so entirely one in their relation to the College, that I dwell somewhat in detail upon these beginnings of Dartmouth, especially upon the services rendered by its founder and refounder.

To understand the educational bearing of the religious motive that actuated Wheelock, and that created the atmosphere in which he was able to develop his plans and carry on his work, we must take due account of that wide and deep spiritual movement which pervaded England and America during the middle of the eighteenth century. The remarkable fact about this movement, more remarkable even than its intensity, was its scope. It reached out beyond the bounds of purely religious concerns into the social, philanthropic, and even political interests of the times. In his "History of England in the Eighteenth Century" (vol. 2, chap. ix) Lecky passes this judgment upon the scope of the movement: 
Although the career of the elder Pitt and the splendid victories by land and sea that were won during his ministry form unquestionably the most dazzling episodes in the reign of George II, they must yield, I think, in real importance to that religious revolution which shortly before had been begun in England by the preaching of the Wesleys and of Whitefield. The creation of a large, powerful, and active sect, extending over both hemispheres and numbering many millions of souls was but one of its consequences. It also exercised a profound and lasting influence upon the spirit of the Established Church, upon the amount and distribution of the moral forces of the nation, and even upon the course of its political history.

The religious life of Wheelock was not the outcome of this revival. It had an independent origin and its own personal development. Wheelock was not a convert or disciple of the religious leaders in England; he was their contemporary. His student life at Yale coincided with that of the Wesleys at Oxford, and preceded by a little that of Whitefield; but he sympathized with their religious aims and was prepared to welcome Whitefield and to coöperate with him on his visits to this country - a friendship and coöperative service which were more than repaid by Whitefield. Wheelock's Indian School was well under way at the time of Whitefield's first visit to this country, and at once awakened his interest. He raised considerable sums of money for its support in New York and Philadelphia, and suggested to Wheelock the plan of sending Samson Occom, the first fruits of the school, to England to raise funds for its support. It was through Whitefield that Wheelock was brought into personal relations by correspondence and through his agents, with Lord Dartmouth and those members of the Established Church who were identified with the evangelical revival, 
and whose minds were as much stirred by the missionary enterprises associated with it, into which Wheelock's work among the Indians fitted in a most timely way, as they were by the greater secular events of the time. The frequent reference in the correspondence between Wheelock and Lord Dartmouth and other London patrons to the "Kingdom of God" was no expression of religious cant, but rather of a most real and vital interest in what they believed to be the greatest matter of human concern. In the light of these facts, the statement in Chase's History of Dartmouth seems to be entirely justified that "without the active assistance of Whitefield and his friends it would not have been possible for Wheelock to develop and carry out his extensive plans. Nothing therefore is truer than that Dartmouth College is peculiarly a child of the Great Revival."

What is termed the romance of Dartmouth is in truth a spiritual romance. It began in the appeal of the idea embodied in Wheelock's Indian School to the spiritual imagination of the Mother Country. It took shape and color in the visit of Samson Occom to England, where he was received not only with curious interest, but with ardent sympathy and eager coöperation, as evidenced in the subscription of ten thousand pounds in behalf of the school, the list headed by His Majesty with a subscription of two hundred pounds, and containing the names of three thousand individuals and churches. ${ }^{1}$ The romantic character of the origin of the College appears more clearly in the fact that as the mirage of the higher education of the Indians disappears, there rise in place of

1 For names of subscribers (about twenty-five hundred) see list in appendix of Smith's II istory of Dartmouth College. (Houghton Mifflin \& Company, 1878.) 
Wheelock's Indian School the substantial walls of Dartmouth College, fitly bearing the name of the statesman as well known in his time for his friendship for the colonies as for his missionary zeal. And if anything further were needed to complete the "romance of Dartmouth," it may be found in the reflection that none of these conditions attending its origin could have happened except in the decade in which they occurred. Ten years from the date of Occom's visit to England and six years from the date of the Charter of the College, the colonies were at war with the Mother Country. Dartmouth was the ninth and last of the colonial colleges. The College might have come into existence under other auspices, but it would have been another college, bearing another name, located elsewhere, possessed of other traditions.

The relation of the College to the name it bears is not limited to the gift of the name. The name was justified by the personal interest of Lord Dartmouth, the second Earl, in the purpose of Eleazar Wheelock as set forth in the Indian School, and by his most influential service in furthering the project. His influence was in harmony with his political attitude to the Colonies while Secretary of State for the Department of America, and with his religious views as an "Evangelical" of the Church of England. The unique fact about the relation is that it survived the War of the Revolution, and passed over into the generations following. As the present Lord Dartmouth, the sixth in the succession, remarked on leaving the College after his visit in 1904, "I am going back from Dartmouth to Dartmouth, between which there has never been a break for one hundred and thirty-five years." I do not know of a like continuous relation between an Amer- 


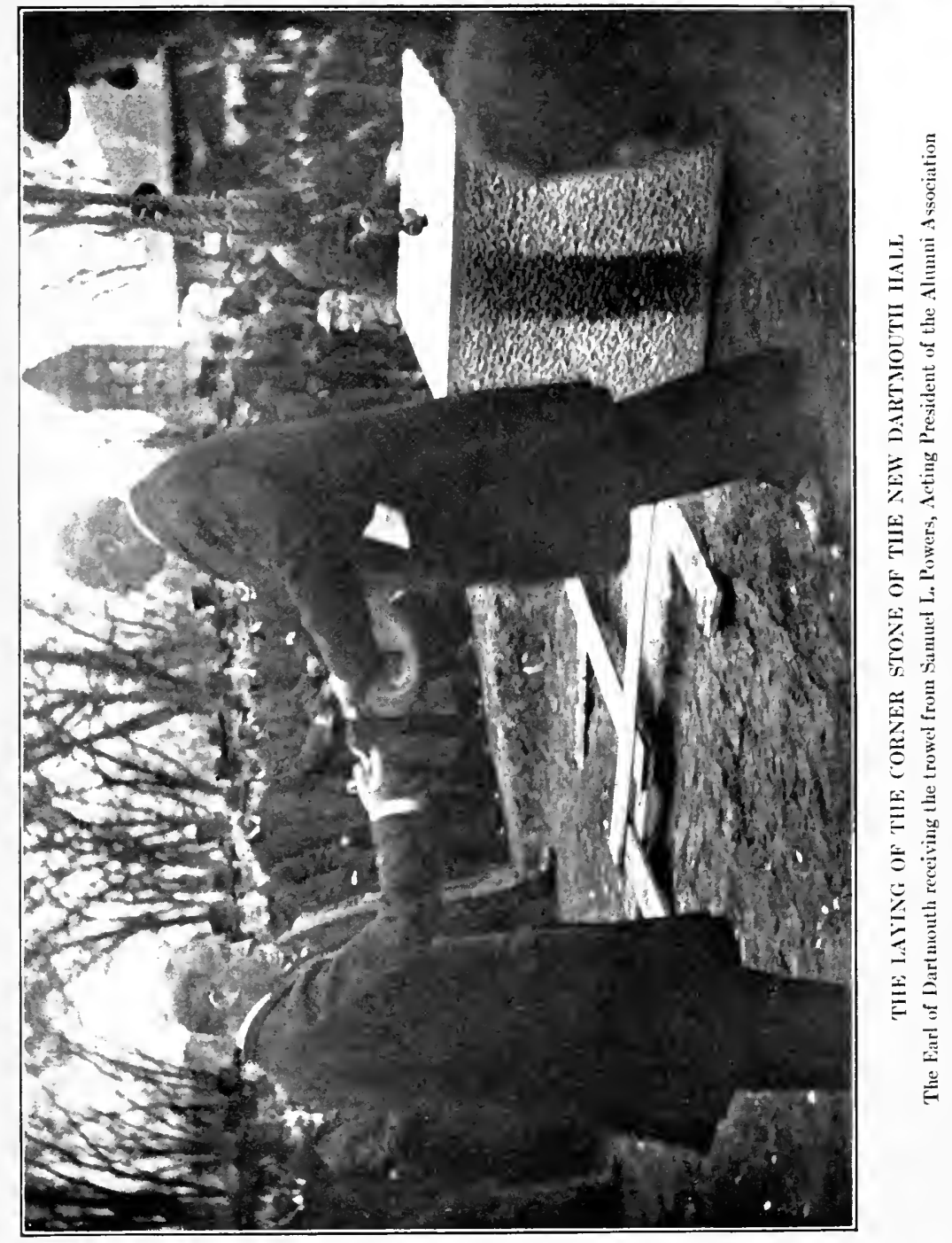



ican college and an English house. This reciprocal relation has been frequently acknowledged. In 1805 Edward Legge (the House of Dartmouth sprang from the Legge family), then Dean of Windsor, afterwards Bishop of Oxford, received from the College the degree of Doctor of Divinity; and in 1860 William Walter Legge, fourth Earl of Dartmouth, received the degree of Doctor of Laws. However, no degree was conferred in person till the visit, to which I have referred, of William Heneage Legge, sixth Earl of Dartmouth. This degree, of Doctor of Laws, was given in connection with the formalities attending the Laying of the Corner Stone of the New Dartmouth Hall by Lord Dartmouth. More recently the relationship has been happily brought to view in England in the circumstance indicated in the following communication from Lord Dartmouth to the editor of the "Alumni Magazine":

Sir:

November 19,1918

I enclose a programme of the Installation ceremony of Lord Robert Cecil as Chancellor of the University of Birmingham. It may not be uninteresting to your readers to know that I was privileged to take part in the procession, attired in the robes presented to me by Ex-President Nichols.

The installation took place on the day following the signing of the armistice, and the appearance of a Dartmouth gown in the very centre of England seemed to me to be a very appropriate indication of an alliance that made the signing of the armistice possible.

Yours Dartuouth

While, however, educational institutions may have their spiritual origin in great movements of thought and faith, they do not come into actual existence except through correspondingly great personal agencies. Eleazar Wheelock 
was emphatically the Founder of Dartmouth College. To him the College owes its existence because he was an embodiment of the creative spiritual influences of his generation, but also and none the less because of the creative and organizing powers of mind which enabled him to conceive plans in true proportion, and which caused him to brook no obstacle in the way of their accomplishment.

As one of his successors, I have on two occasions given my impression of the personality of Dr. Wheelock, and of my feeling toward him. As the occasions were such as to enhance whatever value may have attached to my words, I quote them in their connection. The first occasion was the laying of the corner stone of the present Dartmouth Hall by the present, the sixth Earl of Dartmouth. Among the exercises connected with this ceremony was included a visit to the grave of Wheelock in the College Cemetery. The following brief address was given at his grave:

We are indebted to Professor Richardson, the chairman of the Committee on Arrangements, for the introduction of the fine touch of sentiment which brings us here, at the grave of Eleazar Wheelock, to begin our march to the site of Dartmouth Hall. It is also in accordance with his suggestion that a brief word is spoken here by myself as the successor of Dr. Wheelock.

The gift of the eighteenth century to the colleges of America was the gift of the religious spirit. For other endowments our debt is small. The ministry of wealth to education had not then been accepted, and of organized learning there was little to give. The learning of the time was chiefly pedantry or culture, not distinctively power.

The religious spirit was the great educational endowment, and it was very great, because it was creative. It took possession of fit men and taught them to lay foundations upon which men and states might afterward build securely and broadly. 
Eleazar Wheelock was a man fitted to the uses of this creative and energizing spirit. My conception of him is that of a man of broad understanding, of quick and steadfast imagination, and of an imperious will, which gave him in unusual degree the power of initiative; but I think of him more distinctly as a man able to receive and to make room for those mighty influences which were in his time stirring the hearts of willing and capable men. Eleazar Wheelock was no opportunist, but he was alive in all his nature to the most serious demands and opportunities of his age. It would perhaps be fanciful to assume that, as a college student, the first fellow on the Bishop Berkeley foundation at Yale, he caught the full significance of the great bishop's scheme for education in America. Still it is true that no man ever carried that scheme so near to its realization as did Eleazar Wheelock. In his early ministry there came among the churches of this country the quickening power of George Whitefield. Many opposed Whitefield and his doctrine. Wheelock welcomed him and accepted his message. He became in his own person a recognized part of the "Great Awakening." The visit of Whitefield had been preceded in the providence of God by another visit of a very different kind, which at once suggested, and finally directed, the course of future service. While he was still a young pastor and teacher there came to Wheelock's study an Indian, twenty years of age, asking for advice and help. Wheelock took him to his home as pupil, almost as son, and after four years sent him out equipped for work among the churches. Samson Occom was to Wheelock the embodiment of an idea, an idea which became a purpose, - I had better say, a passion; an idea for which he was ready to endure toil and sacrifice, an idea for which he was quick to plead with the churches and legislatures of his country, an idea which he was not ashamed to present at the court of his sovereign.

It was twenty-six years from the visit of Samson Occom to the signing of the charter of Dartmouth College. At almost threescore, Eleazer Wheelock left his home and church and people, where he had dwelt for thirty-five years, and built his altar and pitched his tent in this wilderness. He had but ten 
years in which to accomplish his work. It was an old man's task. The founding of this College is a witness to the power of a courageous, persistent, indomitable faith.

It would be unjust to this man, standing beside his grave, to deny his faults, faults which inhered in his temperament. Great men do not ask us to forget their faults. This man was great enough to carry them to the end and make his goal.

The writer of his epitaph has caught the spirit of his life. Beginning as a record it ends as a challenge. I have often read it to invigorate my own soul. But it was written not alone for his successors in the office which he created, nor yet for workers in the cause for which he gave his life, but as the writer says, even for the wayfaring man who may pass his grave. I rehearse it therefore in your presence.

By the gospel he subdued the ferocity of the savage;

And to the civilized he opened new paths of science.

Traveler,

Go, if you can, and deserve

The sublime reward of such merit.

The second occasion was the Inauguration of Dr. Nichols as my successor in the presidency. On this occasion I received permission from the Trustees of the College to introduce into the Inaugural Exercises a special recognition of the relation of succeeding Presidents to Dr. Wheelock, under the term "The Wheelock Succession" a term designed to express our peculiar personal as well as official connection with the Founder and first President of the College:

President Nichols, I am permitted by the courtesy of the Trustees to introduce you at this point to a somewhat peculiar, because personal, succession, into which each president of the College enters upon his induction into office. The charter of Dartmouth, unlike that of any college of its time so far as I know, was written in personal terms. It recognizes throughout the agency of one man in the events leading up to and including 
the founding of the College. And in acknowledgment of this unique fact it conferred upon this man - founder and first president - some rather unusual powers, among which was the power to appoint his immediate successor. Of course this power of appointment ceased with its first use, but the idea of a succession in honor of the founder, suggested by the charter, was perpetuated; so that it has come about that the presidents of Dartmouth are known at least to themselves as also the successors of Wheelock, a distinction which I am quite sure that you will appreciate more and more. For Eleazar Wheelock was the type of the man, the impulse of whose life runs on in men, creating as it goes a natural succession; a man whose power of initiative is evidenced by the fact that at sixty he was able to found this College in the wilderness; a scholar by the best standards of his time, the first Berkeley Fellow at Yale; broad and courageous in his mental sympathies, a leader in the progressive movements of his age; and of so high and commanding a devotion of purpose that it brought him to an accomplished end. ... .

Dartmouth, as you know, has been singularly fortunate in the return into its own life of the fame and service of some of her greater sons, singularly fortunate also in the abounding and unflinching loyalty of all of her sons; but I believe that the greatest possession of the College has been and is still the spirit of Eleazar Wheelock in so far as it has been transmitted through his successors. I think therefore that the term "The Successors of Wheelock" is worthy of public, if not of official recognition. Cnwittingly Wheelock himself originated the expression in the very thoughtful provision which he tried to make for those of us who were to come after him. "To my successors," he says in one of the last clauses of his will, not to the Trustees nor to the College, but "to my successors in the presidency I give and bequeath my chariot which was given me by my honored friend, John Thornton, Esquire, of London; I also give to my successors my house clock which was a donation made me by my much honored patrons, the Honorable Trust in London."

It is no matter of surprise, as we recall the utter indifference 
of each generation to those things of its daily handling which are likely to become historic, that these perquisites of the succession have long since disappeared. But happily the intention of Wheelock was caught and held in permanent shape. When John Wentworth, governor of the Province of New Hampshire, returned from the first commencement, he sent back, possibly as a reminder of a deficiency on that occasion, a silver punchbowl bearing this inscription -

"His Excellency John Wentworth, Esquire, Governor of the Province of New Hampshire, and those friends who accompanied him to Dartmouth the first Commencement in 1771, in testimony of their gratitude and good wishes, present this to the Reverend Eleazar Wheelock, D.D., and to his successors in that office."

This bowl, which, as I now produce it, seems so inadequate to the draughts of that time, for this very reason serves us the better as a kind of loving-cup.

In the spirit of the original gift, but after the fashion of the later use, I now transfer it to you with the good will of the long succession, and in the personal hope that it may be many, many years before you will have the opportunity to transfer it to your successor.

\section{President Nichols responded as follows:}

Dr. Tucker, through the years which may be given me to serve this college worthily, I shall guard and cherish this symbol of the Wheelock Succession for the mighty hands through which it has passed, hands which have held high the sacred torch of knowledge to light the homes, the workshops, the streets of the world, that none should grope in darkness, nor lose his way, nor run into any kind of danger because of mental or moral ignorance. I shall cherish this symbol of the Wheelock Succession the more, sir, because it has come into my hands from you, whom $I$ have known and loved as my chieftain.

The introduction of the ceremony of the "Wheelock Succession" into the exercises attending the Inauguration 
of the Presidents of Dartmouth was designed to give reality and spiritual significance to the romantic founding of the College, which because of this character was in danger of being left behind to abide by itself as a spiritual romance, detached more and more from the formal and institutional life of the College. By a singular fate, the refounding of the College had seemed to intervene to give a new as well as more substantial basis. There was a sense in which the founding and refounding were really contradictory. The occasion for the refounding of the College lay in the miscarriage of one of the provisions of the original foundation. According to this provision, the duty devolved upon Wheelock of appointing his successor "to nominate, appoint, constitute, and ordain by his last will such suitable and meet person or persons as he shall choose to succeed him in the Presidency of said Dartmouth" - the person so appointed, however, to continue in office "so long and until such appointment shall be disapproved by the Trustees of Dartmouth College." Recalling the circumstances of the time, this provision appears to have been natural, if it did not prove to be wise. The immediate future of the enterprise seemed to lie in the mind from which it emanated. Wheelock was at the time sixty years old and worn with hardships and trials. He had but a limited time in which to give direction and consistency to his purpose. Who could have a better right or an equal fitness for making choice of his successor?

But $I$ have no doubt that in this provision of the charter of Dartmouth College granting to Eleazar Wheelock as the founder the right to appoint his successor, and in the results which followed the exercise of this right, we have the origin of the Dartmouth College Case. Unwittingly the charter created the con- 
dition for such a controversy. Unwittingly Dr. Wheelock filled out the condition by the appointment of his son, John Wheelock, then Lieutenant Colonel in the Continental Army, serving on the staff of General Gates in New Jersey, probably the best choice he could have made. ... If, however, we eliminate any one or all of the personal characteristics which may have been contributory to the controversy, it is quite easy to see that there were sufficient elements of contention in the situation itself. On the one hand the inheritance from the administration of the elder Wheelock was entirely that of a personal and paternal government. The younger Wheelock was simply asked to take his father's place. There were no other traditions attaching to the place than that of personal government. Nobody at the time had any other conception of the administration of the college. When other and broader ideas came in, after the lapse of two or three decades, especially through changes in the Board of Trustees, then occasions arose and multiplied for differences, disagreements, and contentions. The changes in the Board of Trustees during the first fifty years of the college from the date of its founding, 1769, to the decision in the Dartmouth College Case, 1819, were very marked. This Board, consisting of twelve men, was made up at the first in about equal parts, of the political associates of Governor Wentworth in New Hampshire, and of the ministerial friends of Dr. Wheelock from Connecticut. The War of the Revolution falling within the first decade changed almost entirely the composition of the Board. Two only of the charter members remained through the ten years' administration of the first president. Governor Wentworth withdrew at the outbreak of hostilities in 1775. The Connecticut members gradually withdrew, owing in part to their local interests in their own colony. The college thus separated from its English patrons, and from many of its supporters in the other colonies, became for the time isolated. Dr. Wheelock was obliged to rely more and more upon his personal friends, among whom may be mentioned John Phillips of Exeter. Vacancies in the Board as they occurred were filled by friends, and in two cases by relatives. The Board of 'Trustees in existence at the death of 
the elder Wheelock in 1779 , which urged the succession upon his son, was in reality, though apparently without design, so organized as to perpetuate the family control of the college. Within twenty years the names upon the Board as then constituted disappear, with two exceptions, and thereafter quite a different type of trustee comes into prominence - Nathaniel Niles, Judge of the Supreme Court of Vermont, elected in 1793; Thomas W. Thompson, Member of Congress, in succession, in both branches, 1801; Timothy Farrar, Judge of the Court of Common Pleas of New Hampshire, 1804; Elijah Paine, Esquire, of Vermont, 1806; Charles Marsh, Esquire, U.S. District Attorney and Member of Congress, 1809 - an acquisition of legal ability which gave the Board a distinctly legal character, and which peculiarly fitted it, as occasions might arise, for controversial action. ${ }^{1}$

The occasion for open conflict between the President and the majority of the Trustees did not arise until after some years of friction in the college community and throughout the college constituency, and of suppressed conflict within the Board. The President had now been in office thirty-five years, the last fifteen years of which had been a period of uninterrupted contention. It is necessary to keep this fact in mind in order to understand the sudden and vigorous outbreak of hostilities. The state of feeling which had been engendered, was intensified by the publicity to which each side resorted in giving out charges and counter-charges. The charges on either side were as follows. In his memorial to the Legislature of New Hampshire, its President Wheelock charged that the majority of the Trustees had "forsaken its original principles [of the charter] and left the path of their predecessors"; that by

1 Quotation from my address on the "Origin of the Dartmouth College Case," given before the New Hampshire Bar Association on occasion of its celebration of the Centennial of Chief Justice Marshall, Manchester, February 4, 1901. 
improper "means and practices they [had] increased their number to a majority controlling the measures of the Board"; that they had "applied property to purposes wholly alien from the intention of the donors"; that they had "transformed the moral and religious order of the institution by depriving many of their innocent enjoyment of rights and privileges for which they had confided in their faith"; and that they had "broken down the barriers and violated the charter by prostrating the rights with which it expressly invests the presidential office."

In the counter-charges the Trustees claimed that President Wheelock had sanctioned in printed documents known as the "Sketches" and the "Memorial," "a gross and unprovoked libel upon the institution"; that he had set up "claims which in their operation would deprive the corporation of all its powers"; that he had "been guilty of manifest fraud in the application of the funds of Moor's School" in foisting an assumed Indian upon the Scotch fund; and that he had "in various ways given rise and circulation to a report that the real cause of the dissatisfaction of the Trustees with him was a diversity of religious opinions between him and them, when in truth and in fact no such diversity was known or is now known to exist, as he has publicly acknowledged before the committee of the Legislature appointed to investigate the affairs of the College."

In reviewing these charges and counter-charges one can but feel how insufficient they were in their generalities to bear the weight of the subsequent contention. So it appeared at the time to the clear and sagacious mind of Jeremiah Mason. The particular act of President Wheelock which seems to have carried the contention to the break- 
ing point, was the direct appeal in his "Memorial" to the Legislature of New Hampshire, that it would make such "organic improvements and model reforms in its system and movements [of the College] as under Divine Providence will guard against the disorders and their apprehended consequences." To the object, avowed or implied, in this appeal, the Trustees made answer by deposing the President, according to the authority granted them by the charter and by electing the Reverend Francis Brown in his place. Of course this action closed the contention between President Wheelock and the Trustees; but it carried the controversy into politics and opened the way into that larger contention which was to become in due time the Dartmouth College Case. The political party then in opposition was quick to take advantage of the situation and at the next session of the Legislature, June, 1816, secured the passage of an act "to amend the charter and enlarge and improve the corporation of Dartmouth College," increasing the number of Trustees to twentyone, and changing the name of the College to Dartmouth University. A Board of Overseers was also added and the necessary legislation, both restrictive and expansive, was introduced to convert the College altogether into a State University. Although the Trustees were hardly prepared for such drastic and subversive action to be enforced by the power of the State, they did not shrink from the unequal contest. Their action took the form of a suit before the Superior Court of New Hampshire to recover the records and seal of the College, which had passed into possession of the University through the defection of Judge Woodward, the Secretary and Treasurer of the Trustees. This suit raised at once the question of the con- 
stitutionality of the act of the Legislature establishing the University. The case was argued with great ability by Attorney-General Sullivan and Ichabod Bartlett in behalf of the State, and by Jeremiah Mason and Jeremiah Smith in behalf of the College, Mr. Webster, who as junior counsel had kept somewhat in retirement during the procedure, making a brief closing argument. The decision of the court was unanimously in favor of the State, upholding the constitutionality of the legislative act establishing the University.

The adverse decision of the court revealed the seriousness of the contest upon which the College had entered for the restoration of its chartered rights. What added not a little to the disheartening effect upon the friends of the College was the attitude at this time of many officers and graduates of other colleges, who, now beginning to realize the common danger, were fearful of graver results if the case should be appealed to the Supreme Court of the United States. They felt that they might not be affected by any like decision in the courts of their own States, and preferred to rest in this uncertainty rather than to join in an attempt to gain the assurance of a general and permanent security. 'The Trustees and their counsel, though not altogether surprised at the decision, and still undaunted, were somewhat doubtful as to the nature of future proceedings, especially in regard to the scope of the appeal.

It was at this juncture that Mr. Webster really entered the case, bringing to bear upon it all his legal resources and throwing into it the whole weight of his personality. From this time on it was his case. He chose the strategic point for the appeal to Washington. He reorganized the case to meet the enlarged conditions of its new environ- 
ment. Associating Judge Hopkinson, of Philadelphia, with him, he prepared the case with scrupulous care. Nothing was wanting to the completeness of the argument, nothing to the force of its application, not even the sincere touch of personal emotion which carried it to the hearts of the judges. When the decision of the Supreme Court was rendered, reversing that of the State court, and reëstablishing the College in its chartered rights, Mr. Webster stood forth as the victorious champion of what had been a mightily imperiled cause. Before the country had grasped the scope of his argument, it was caught by the splendor of his courage. Something of this high distinction of courage fell upon the College. The Dartmouth College Case under Mr. Webster's management gave to the College a courageous and chivalrous aspect, corresponding to that adventurous aspect which it at first assumed from the religious heroism of Dr. Wheelock.

In the year 1901 the College observed the centennial of Mr. Webster's graduation. ${ }^{1}$ It was an unusual academic event, but the relations of $\mathrm{Mr}$. Webster to the College both

1 Through a striking coincidence, the founding and the refounding of the College, that is, the conferring of the Charter and the decision of the Supreme Court, fall upon dates just fifty years apart, so that any academic commemoration of either event will naturally include the other. Thus, before the War, the year 1919 had been kept in mind as the date for the celebration of the one hundred and fiftieth anniversary of the signing of the charter and the one hundredth anniversary of the decision of the court. But two occasions arose meanwhile (one entirely unexpected) which brought these two events in turn vividly before the College. The first was the celebration of the centennial of Mr. Webster's graduation (1901); the second three years later marking the laying of the corner stone of the new Dartmouth Hall and the visit of the Earl of Dartmouth to the College. Memorial volumes were carefully prepared, edited by Ernest Martin Hopkins, then Secretary to the President, recording the various speeches and addresses, and narrating the incidents of interest attending the celebrations.

The Webster Centennial contains the very comprehensive but most discriminating oration by Governor (then Congressman) Samuel W. McCall on "Webster's Career"; papers of Professors John K. Lord and Charles F. Richardson; 
personal and professional were so unusual as to make the event appropriate and significant. In my introductory words in explanation of the occasion, I sought to interpret the feeling of the College to Mr. Webster:

The observance of the Centennial of Mr. Webster's graduation from College is an academic event of its own kind. I am not aware of an instance in which a college has taken note in a formal way of the graduation of any of its alumni. The motive which has led us to observe this event is so natural and evident, that our action invites, I think, neither criticism nor imitation. We have not sought to introduce a custom. No college or university may see fit to celebrate a like event in its history. We may have no occasion to repeat these observances under other conditions.

The relation of Mr. Webster to his College, his living and his posthumous relation, is unique. It is doubtful if the name of any educational institution in the land is so inseparably blended with the name of a graduate, or even of a founder, as is the name of Dartmouth with that of Daniel Webster. The story of the founding of this College by Eleazar Wheelock is a romance, the great educational romance of the eighteenth century. The story of its "refounding" by Daniel Webster is written in law, the law of the land since 1820. Had Mr. Webster died immediately after the Dartmouth College decision he would have left the College imbedded in the national life. The after years of his personal fame were of almost equal service to the College. His

and speeches by Governor Jordan, Edwin Webster Sanborn, Esq., Judge David Cross, Dr. Edward Everett Hale, Senator Hoar of Massachusetts, and Chief Justice Fuller.

The Laying of the Corner Stone of the New Dartmouth Hall contains the illuminating Historical Address of Professor Francis Brown on "The Origins of Dartmouth College"; the various speeches of the Earl of Dartmouth; the "Corner Stone Ode" of Wilder D. Quint; and the responses at the Banquet by the Earl of Dartmouth; Charles T. Gallagher, Esq., on the "Dartmouth and Washington Arms"; Dr. Charles A. Eastman on "The Native American for whom Dartmouth College was founded "; Governor Bachelder of New Hampshire; President Eliot of Harvard; President Tyler of William and Mary: and the Honorable Elihu Root on "Samuel Kirkland, Founder of Hamilton College: Eleazar Wheclock's Pupil and Fellow Worker in Indian Education." 
reputation, his influence, his memory became a part of our institutional assets. We cannot tell to-day whether we owe more to Mr. Webster for what he did or for what he was.

And yet in this relation of Mr. Webster to the College, unique as it is, there is nothing unnatural or exaggerated. He belongs to us because he was one of us. There was nothing to set him apart or separate him, except size. He was "to the manner born." A New Hampshire boy, he never thought of entering any other college than Dartmouth. And once here he found all that he needed at that stage of his development. The Dartmouth of Mr. Webster's time was quite abreast of the still older colleges with which it is associated. During the decade which included the greater part of his collegiate course, Dartmouth graduated three hundred and sixty-three men, Harvard three hundred and ninety-four, Yale two hundred and ninety-five, and Princeton two hundred and forty. Mr. Webster referred in his argument to Dartmouth as a "small college." It was a small college, but not small as related to its neighbors, nor insufficient as related to its work. It gave Mr. Webster what he was capable of receiving in the way of instruction, stimulus and opportunity. And when the time came for him to repay his debt to the College he simply did his duty. He did no more than he ought to have done, no more than any graduate ought to do for his college with a like opportunity before him and with equal resources at his command. It was natural, too, that he should continue to love his college to the end, and rejoice that he was a part of it, as natural as was his love of kindred and of nature. I dwell upon the simplicity and constancy of Mr. Webster's feeling toward the College, because these qualities explain so largely our feeling toward him. His loyalty was commensurate with his power of service, his affection was as deep as his nature. . . .

It may be pardonable to add to this word of explanation the reminder of the fact that as we celebrate this past event, we find ourselves in the presence of a living personality. No man of his time has borne the gradual transfer from memory to tradition with so little loss. No name out of his time is so familiar to-day as his name. Mr. Webster was never loved by the people at large 
as some men have been loved. Popular affection as it went out toward him grew hesitant in the approach and became awed in his presence. It did not quite dare that passionate fondness which some men allow in their success; it did not dare that compassionate tenderness which some men would welcome, which he might have welcomed, in decline and defeat. But in one respect the personal influence of $\mathrm{Mr}$. Webster surpassed and continues to surpass that of all other men, namely, in his influence over the ambitions of young men. During his life-time Mr. Beecher had many imitators. Mr. Webster's power was deeper, more searching, more creative. It touched the center and core of personal ambition, stirring young men to make the most of themselves and to act with most effect upon others. Mr. Webster has been and still is a potent influence in sending men to college, into the law, and into politics.

Measured in broader terms his influence is vital to-day in the thought and feelings of men in respect to the country. We have learned, we have begun to learn, to think about the country in his terms, and to feel about it as he felt. His conceptions were so great that they could find room only in his own mind. They belong to the United States of to-day, not to the nation of his time. Thus far Mr. Webster is the only man who has comprehended the American people. Until a greater American than he shall arise, he will live in the still unfulfilled destiny of the Republic.

In following the extraordinary course of events which carried the case of the College to Washington we may not allow ourselves to lose sight of the events which were at the same time taking place at the College itself; nor may we allow our absorbing admiration for the courageous bearing of Mr. Webster, amounting as it did to a sane audacity, to overshadow an exhibition of equal courage of a different type in the person of the youthful President of the College. When the trustees deposed President Wheelock, they turned to Francis Brown, for three years 
after his graduation a tutor, and then pastor of the church in Yarmouth, Maine, as the most competent man for the succcession. He was but thirty-one years of age, and but ten years out of college; but they believed that they knew the man and dared to trust him with what was not only a great but at the time a very unusual responsibility. They could not have foreseen, and certainly he could not have foreseen all the consequences which were to follow the deposition of the President, but they knew that in taking this step they incurred grave risks. It seemed, nevertheless, necessary and wise to incur them; but the wisdom of their action could be justified only by the wisdom of their choice of a successor to the deposed President. I am convinced that with any other man than President Brown in the position the cause of the College would have failed. The situation was full of pitfalls. Any misstep would have been prejudicial to the case and might have made the legal contention of the College untenable. President Brown, in company with his associates, Professors Adams and Shurtleff, held the local position not only firmly, but without prejudice to the efforts of the counsel for the Trustees. The official correspondence of the President with the Governor of the State was conducted with rare diplomacy, and his correspondence with the President of the University, a still more delicate business, with equal skill. The relations between College and University were kept within the bounds of a reasonable courtesy. And meanwhile the college exercises went on with regularity. The students were held to their duties with a certain enthusiastic devotion. There was but slight decline in numbers during these dark and uncertain days. The presidency of Dr. Brown lasted but five years, from 1815 
to 1820 . The number graduating within those years was one hundred and forty-three - but fifty less than in the previous five years, and but seventeen less than in the five following. Certainly there was no decline in quality. Rufus Choate graduated in 1819 (the year of the decision of the Case), and George P. Marsh in the year after. Meanwhile, the loyalty of the President could not be shaken, nor his courage. At the time of greatest confusion he was offered the presidency of Hamilton College with twice his salary. It was no temptation to him. The Legislature passed an act inflicting penalties upon him and his associates if they continued to fulfill their duties as college officers. They continued without a break in the discharge of their duties. While the College was before the courts, the position at Hanover was held without flinching. Any other course would have been fatal to the whole cause. As Trustee Marsh, then a member of Congress, wrote the President from Washington - "With your abandonment would expire the remaining hopes of the friends of Dartmouth." That was an impossible alternative to Francis Brown. The struggle cost him his life, but he died at his post, surviving only a year the victory of Mr. Webster at Washington. He belongs by every right within the heroic period of the history of the College. Nothing could be more fitting than the tablet to his memory (see page 295), placed within the Hall which bears the inscription to Wheelock and Webster.

I have made much account of the traditions of Dartmouth because they retain their influence. They have entered into the institutional life of the College. They form a part of the Dartmouth discipline. Unconsciously, doubtless, to the average undergraduate, but none the 
FRANCIS BROWN, S.T.D. PRESIDENT OF DARTMOUTH COLLEGE

$$
\text { 1815-1820. }
$$

A MINISTER OF THE GOSPEL IN NORTH YARMOUTH MAINE CAILED TO THE PRESIDENCY OF THE COLLEGE IN THE CRISIS OF ITS AFFAIRS WHEN THE STATE LEGISLATURE THREATENED TO CHANGE THE CHARTER OF THE COLLEGE AGAINST THE WILL OF THE TRUSTEES HE ACCEPTED THE CALL AS THE WAY TO DUTY.

FOR FIVE YEARS UNCHECKED BY OBLOQUY

UNDAUNTED BY DIREST POVERTY UNENTICED BY OFFERS OF PERSONAL ADVANCEMENT UNDISMAYED BY THE ADVERSE DECISION OF THE STATE COURTS HE CONDUCTED THE AFFAIRS OF THE COLLEGE

UNTIL A DECISION OF THE SUPREME COURT OF THE UNITED STATES

ESTABLISHED THE VALIDITY OF THE EARLY CHARTER. WORN OUT BY THE STRUGGLE HE DIED JULY 2iTH 1820 IN HIS THIRTY SEVENTH YEAR. HIS UNTIRING LABORS HIS ADNINISTRATIVE ABILITY AND HIS HIGH PERSONAL CHARACTER GAINED FRIENDS FOR THE COLLEGE AND HELD THE STUDENT BODY FIRII IN ITS ALLEGIANCE TO

THE INSTITUTION WHICH HE HAD THOCGHT WORTHY THE SACRIFICE OF HIS LIFE. IN RECOGNITION OF HIS MIERITS THIS TABLET IS ERECTED ON THE CENTEYARY OF HIS ACCESSION BY THE ASSOCIATION OF ALUMNI OF DARTMOUTH COLLEGE. 
less truly, they are a vital element in the intellectual and moral atmosphere which surrounds him. Their ultimate effect, however, is manifest in the graduates of the College. At certain periods they have been influential in determining the choice of a profession. At all times they assert themselves in the determination of the qualities which are accounted of most value in practical life. I have been greatly interested in observing how surely the traditions of the College, if by any chance they have been submerged under the passing enthusiasm of an undergraduate generation, reappear in the graduate of after years. The great traditions are so persistent that they seem at times monotonous, but they never cease to be vital.

\section{III}

\section{Reconstruction and Expansion}

It is an abrupt transition from the epoch when Dartmouth was making its traditions to the time when, in common with the historic colleges, it entered upon what I have termed the modernizing process - the era of reconstruction and expansion. But as this review is autobiographical, not historical, except when historical reference is necessary, I pass directly into the period with which I was personally and professionally concerned. I may call attention, however, to a peculiar characteristic of the intervening period for its bearing on later results. This period was remarkable for its productivity in graduates of public influence and position. Each college contributed its quota, and usually added something to indicate its type. Dr. William T. Harris, whose position as United States Commissioner of Education gave him unusual opportunity for estimating the characteristics of public 
men, told me that in his judgment the Dartmouth characteristic was "directive power." This opinion led me to look into the record of the College in Congress, where it had always been represented in one or both Houses from the organization of the Federal Government. It seemed to me that the record justified Dr. Harris's opinion. And as I visited from time to time the alumni associations in various parts of the country, I became confirmed in the discrimination of this judgment, as I examined into the qualities of the early leaders in the educational, political, and in some cases economic interests of the States.

Possibly there may have been some connection between this productivity of the nineteenth-century college in graduates of the general type referred to, and the relative place then held by the faculty in a college. The graduate may have been the more direct product of the teaching force. Certainly the teaching force as then individualized was the most distinguishing feature of a college, far more distinguishing than the physical properties of the college, or even its curriculum, or its administration. Several of the more influential college presidents were such by virtue of their teaching ability quite as much as by their ability as administrators - Woolsey of Yale, Hopkins of Williams, IVayland of Brown, Felton of Harvard.

But in the closing decades of the century it became evident that college teaching, if it was to maintain its effectiveness, must be supported and supplemented by agencies quite out of reach of the individual instructor; and also that it must be at once more sharply differentiated and more highly organized. This was the meaning of the modernizing process which awaited the colleges, in which the emphasis was to fall upon college administration. It is 
not too much to say that the necessity for the modernizing of the colleges virtually created the science of college administration, which in its inner working is the science of coördination and adjustment, and in its outer relations the scientific application of economic principles to the material necessities of the colleges. The modern college is thus, by distinction from the type out of which it emerged, in much larger degree the product of the college administrator.

It may be difficult to distinguish at all points between the results of the normal institutional development of the colleges, and the results of the modernizing process. The normal development involved growth and advances, sometimes very marked - advances in instruction, increase in endowments, growth in numbers both of faculty and students. The institutional development of Dartmouth which began under President Lord, when its physical shape was determined and its educational character established, steadily continued throughout his thirty-five years of administration (1828-1863), and proceeded normally under the administrations of his successors, Presidents Smith and Bartlett. The College not only took on a strong impress from the personality of these administrations, but it carried over into its future, permanent deposits of material resources and permanent gains in educational values. Like results obtained in all the New England colleges. Administrations varied in their relative influence, and yet any one familiar with the college history of New England in the nineteenth century can trace the institutional development of the various colleges from decade to decade. But the modernizing of these colleges, when it came, was a different matter from the normal institutional development which had gone before. 
The modernizing process made at least these three demands upon the colleges - first, adequate provision for the new subject-matter of the higher education, a demand which involved not only the reconstruction of the curriculum but also, in most cases, of the college plant; second, the reorganization of faculties based on departments rather than on individual chairs of instruction, a change made necessary, together with various modifications of college instruction, through the incoming of the Graduate School, and the reliance of the colleges upon these schools for instructors and for methods of instruction; third, the adjustment of the student body to these changed conditions, an adjustment effected chiefly through the elective system, involving changes in the moral as well as intellectual habits of students. Coincident with these new demands upon the colleges - a fact not to be overlooked - was a sudden and rapid enlargement of the constituency of the colleges, brought about by the rise of the high school as a fitting school for college. According to the statistics of the United States Commissioner of Education, there were in 1880 about eight hundred high schools in the country, in 1890 twenty-five hundred, and in 1900 over six thousand. Not all of these were accepted fitting schools, and only a proportion of students in the competent schools took the preparatory courses. But the number of competent schools, and of students in preparation for college constantly increased, with the result that the educational and the material problems of the colleges were perceptibly augmented. And to these specifications must be added the further fact applying to the country colleges, that the reconstruction and expansion of each college, so situated, usually required the transformation of the village in which 
it was located. The material changes necessary to insure sanitation and economic conveniences, though apparently elementary, as in providing for an adequate supply of water, heat, and light, were often far reaching and costly.

The modernizing process at Dartmouth was somewhat belated. The delay, however, was not altogether to the disadvantage of the College. It gave the opportunity to determine the nature of the expansion of which the College was capable. The modernizing of the colleges was not an external process imposed upon all alike without regard to the individuality of each. It was in all cases an internal process, subject to certain inflexible conditions, but in no respect a purely standardizing process. In the case of Dartmouth, it was determined to make use of the process to test the capacity of the College for expansion, having in mind both the vigor of its constitution and the opportunity for stimulating and strenuous exertion. In other words, the policy adopted was not that of a programme. It was a policy of inward development, determined and measured by the reach of its resources, by the response of its constituency, and by the return of its increase and enlargement upon itself. Expansion was to mark the limit of the productivity of the College under the most stimulating treatment consistent with safety. The process of expansion presented itself in a series of problems - the financial, the physical, and the strictly educational. The physical involved the reconstruction of the college plant; the educational, the enlargement of the curriculum and the increase of the faculty.

It was greatly to the advantage of the College that in the work now before it, it was under the control of a single board of management and that not too large for respon- 
sible and effective action - the Board of Trustees consisting of twelve men including the Governor of the State ex-officio. The Board as reconstituted through the election of five alumni members acquired fresh strength. The situation called for its reorganization. A like reorganization of the faculty in the interest of administrative effectiveness was to follow. The Board of Trustees was reorganized to act through the five essential committees, on finance, instruction, buildings and improvements, on the relation of the College to the alumni, and of the College to the State. During this period, 1893-1909, the Chairman of the Committee on Finance was Judge James B. Richardson, 1893-1903, and the Honorable Benjamin A. Kimball, 1903-1909; Frank S. Streeter, Esq., was Chairman of the Committee on Buildings and Improvements throughout the entire period; and the successive chairmen of the Committee on Instruction were Dr. A. H. Quint, 1893-96, Dr. C. F. P. Bancroft, 1897-1901, Dr. Cyrus Richardson, 1901-06, and Professor John Robie Eastman, 1906-1909. While the policy of educational expansion was taking shape, there were joint committees with the Faculty on instruction and equipment (including library and laboratories), and on degrees.

It was also fortunate for the College that it was able to enter on its policy of expansion through a process of contraction which contributed in marked degree to its unity. The title of the annual catalogue for 1892-93 ran - "Catalogue of Dartmouth College and Associated Institutions." The Associated Institutions were the Medical School (1798), the Chandler School of Science and the Arts (1851), the New Hampshire College of Agriculture and the Mechanic Arts (1866), and the Thayer School of Civil Engi- 
neering and Architecture (1871). During the academic year, 1892-93, the New Hampshire College of Agriculture and the Mechanic Arts was removed to Durham, and the incorporation of the Chandler School into the College as a scientific course leading to the degree of Bachelor of Science was effected. There remained only the Medical School and the Thayer School to be readjusted.

The financial policy adopted by the Trustees was not made to depend upon a campaign of general solicitation at the beginning or at any later time. In this respect it differed at least in degree from the traditional and current policy of the colleges, in the emphasis placed upon their eleemosynary character. Colleges legitimately deserve this character. An endowed college is as justly a subject of public benefaction as a state university is a fit subject for public taxation. But while the eleemosynary theory holds a permanent truth, I believe that it should never be permitted to repress the ambition or to lessen the sense of responsibility on the part of any college to make itself to the largest extent possible a self-supporting institution. Especially is it true that an historic college is not warranted in placing itself before the public on the same footing with a college, perhaps of like character, struggling into existence. The historic colleges are all possessed of an intangible wealth which can be made productive. They have at least these three sources of self-support - first, the earning capacity of the college; second, the free, though it may properly be the organized tribute of those who have profited by its advantages; third, the goodwill if not obligation, of a large constituency associated with it through its history or through its activities. The essential thing in the financial development of an historic col- 


\section{THE DARTMOUTH PERIOD}

lege is the order in which it shall draw upon its resources. This I believe should be in the order just named. The antecedent conditions on which an established college may appeal to the larger public are the assurance that its earning capacity has been properly developed, and some clear evidence of the appropriate support of its graduates. The criticism to be passed upon most of the endowed colleges was that of a disproportionate reliance upon their endowments. No equivalent effort was made to increase their earning power.

The policy of beginning the work of expansion at Dartmouth by developing to the fullest extent the earning power of the College required no little courage and faith, but sufficient means were within reach, if not in hand, to justify the effort. The most substantial of these resources was the Tappan Wentworth fund, the bequest (1875) of the Honorable Tappan Wentworth, a native of New Hampshire, of the Governor Wentworth stock, to become available for the uses of the College when the amount bequeathed, $\$ 300,000$, should reach $\$ 500,000$. The property consisted mainly of real estate in the city of Lowell, where Mr. Wentworth passed his professional career. At the instance of Mr. C. W. Spalding of the Board of Trustees, three appraisers, citizens of Lowell, selected by the officers of one of the Lowell banks, were appointed to value the estate. It was found that the estate had reached the amount required for its use by the College, subject to the liquidation of two small mortgages, and to the payment from the income of certain considerable annuities. The fund would become operative in two years, though not free from annuities for an indefinite time. Otherwise the fund was without conditions, and could be ap- 
plied, where it was most needed, to the increase of the Faculty and the extension of the curriculum.

Two other funds (for specified purposes) were of timely aid - one the bequest of $\$ 140,000$ by Dr. Ralph Butterfield of Kansas City, a graduate of the class of 1839, available for the organization of the Biological Department; the other the gift of $\$ 175,000$, subject to minor annuities, by Mr. Charles T. Wilder, a generous neighbor in the adjacent manufacturing village of Olcott Falls (now Wilder), available for the extension of the Department of Physics. To these funds are due the first of the permanent buildings in this period of construction - the Butterfield Museum, and the Wilder Laboratory.

Very timely aid at this juncture came from the State through a grant by the legislature of 1893-94 of $\$ 15,000$, to be divided between the two years. This grant was especially significant (despite the fact that the appropriation of the next legislature was vetoed by the Governor), as establishing a policy of state coöperation. Subsequent appropriations have been: $1897-98, \$ 10,000 ; 1899-1900$, $\$ 20,000 ; 1901-02, \$ 30,000 ; 1903-04$ and subsequently within the period, $\$ 40,000$. This recognition of itself by the State as a legitimate partner in developing the earning power of the College was consistent with the chartered relations of State and College, and with the early traditions. By the charter of the College, the Governor of the State is a member ex-officio of the Board of Trustees, and the Governor's Councillors are Trustees on all matters relating to any funds given by the State, as in the care of the second College Grant. In making this particular grant, the State expressed its desire to have a part in the general as well as local work of the College - "to render it still more useful 
in all future time in promoting literature (and elsewhere 'science') among all mankind." But particularly the State, in inaugurating this special system of annual appropriation, recognized its obligation to make some appropriate return for the expense incurred by the College in the education of its sons. The preamble, introducing the annual appropriation, was as follows - "Whereas, in the education of New Hampshire students Dartmouth College is annually expending more than - dollars above all amounts received for tuition, or grants from the State or its citizens, and whereas the policy of aiding the College in its educational work by annual appropriations has become definitely established in the State, be it enacted," etc.

By far the most serviceable fund, however, for the carrying-out of the full scheme of the Trustees was the Fayerweather, which was set apart, consistently with the terms of the bequest, as a fund to meet the annual deficits inevitable during a period of reconstruction. The greater part of the large estate of Mr. Daniel B. Fayerweather, a philanthropic merchant of New York, had been bequeathed to several educational institutions. After somewhat protracted litigation, the portion which ultimately fell to Dartmouth, amounted to $\$ 223,000$. Upon receipt of the first installment of $\$ 100,000$, less certain costs of litigation, the Trustees had voted (February 8, 1892) to appropriate the sum of $\$ 66,500$ to extinguish the debt incurred by accumulated deficits. This vote gave the suggestion of utilizing any further installments of the bequest as a profit and loss reconstruction fund. The whole of the remaining portion of the fund was so used, and in this use rendered an invaluable service to the College. The name of Mr. Fayerweather is perpetuated in the Fayerweather 
Row of dormitories, but the effect of his bequest cannot be localized. No fund of many times its value, if it had been restricted in its uses, could have served an equal purpose at this juncture in the development of the College.

A further relief of the financial situation lay in the fact that the initial improvements necessary to the reconstruction of the college plant were of a kind to be at once and permanently remunerative. This fact allowed, under proper limitations, the investment of certain undesignated funds of the College in its own development. The elementary improvements had to do with the physical problems of a college in the country - water, heat, light, and sanitation. The first improvement was the introduction of an abundant supply of water into the Precinct of Hanover at a cost of $\$ 65,000$, the College investing $\$ 25,000$ and the Precinct $\$ 20,000$, the remaining $\$ 20,000$ being bonded. At a later period the entire watershed of about 1400 acres surrounding the reservoir was purchased at a cost of $\$ 34,000$. The whole investment, which was a sanitary necessity, proved to be valuable pecuniarily. This improvement was followed by the inauguration of a heating plant at a cost of $\$ 77,000$, containing a battery of 8 boilers of 125 horse-power each, operating through 7900 feet of steam pipe, and heating 39 college buildings; to which was added an electric lighting plant at a cost of $\$ 34,000$, running three dynamos of $75 \mathrm{~K} . \mathrm{W}$. each and equipped for powrer service wherever needed in the College, as well as for lighting.

So far as I can learn, Dartmouth was the first college, at least in New England, to inaugurate and operate an independent heating and lighting system. The innovation has been as successful financially, as it has been advan- 
tageous in other respects. After paying all charges, including interest account and depreciation, there has been a considerable annual surplus applied to the liquidation of the invested fund. In 1909, the Treasurer reported a reduction of $\$ 24,000$ on the original investment of $\$ 117,000$; in 1917 , a reduction of $\$ 89,000$ on an investment of $\$ 153,000$.

In providing for the departments of instruction, new and old, it was planned that each department or each related group of departments should have its own building or buildings constructed with reference to its special needs. Following this plan, the Butterfield Museum was built in 1895 for the Departments of Geology, Biology, and Sociology; Wilder Hall in 1899 for the Department of Physics; the Chandler Building (remodeled) in 1898 for the Departments of Mathematics and Engineering; Tuck Hall in 1904 for the Tuck School, but providing for the time for the Departments of History, Economics, and Political Science; Dartmouth Hall, rebuilt by the alumni in 1904, for the Departments of Ancient and Modern Languages, and Philosophy; and Webster Hall, erected by the alumni in 1907 for the use of the College on all academic occasions. In 1909, plans had been accepted for a New Gymnasium to be built from funds contributed chiefly by the younger alumni. The corner stone was laid by President Nichols at his Inauguration.

The re-creation of a college plant in a village like Hanover involved the problem of housing and otherwise caring for students as well as of providing adequate lecturerooms and laboratories. With the natural increase of students the resources of the village were quickly exhausted. It was necessary to devise a system of dormitories adequate to meet the rapidly growing demands of 
the College. Since the old dormitories, Thornton, Wentworth, Reed, and Hallgarten, accommodating about two hundred students, were outgrown, new dormitories were created in the following order: Sanborn House (50 students), 1894; Crosby House (45), 1896; Richardson (50), 1897; Fayerweather (85), 1900; Hubbard House (20), 1899; College Hall, including Club House and Commons (40), 1901; Elm House (20), 1901; Wheeler (98), 1905; Hubbard No. 2 (48), 1906; Fayerweather North and South (100), 1907; Massachusetts (88), 1907; New Hampshire (107), 1908.

The newer buildings making up the college plant were about equally divided between non-productive and productive buildings. The non-productive buildings were in all cases erected out of funds which came to the College by bequest or by gift for the uses to which they were put Butterfield, Wilder, Chandler, Tuck, New Dartmouth, and Webster. The productive buildings, including most of the dormitories, were built as investments. The amount thus invested during the period of reconstruction was $\$ 901,000$, including cost of improvements, like water supply, heat, and electricity. Had the Trustees limited the growth of the College to the results attending the solicitation of funds for productive buildings, they would lave restricted the College to the fortune of charity, or have given over the dormitory system to private enterprise, as in the earlier stages of development at Cornell, and at certain periods in the expansion of Harvard. I shall have occasion to refer later to the social significance of the exclusion of private dormitories, but I note at once the sanitary effect of the control of the dormitory system as evidenced by the very unusual health record of 
the students under the inspection of the dormitories by Dr. Kingsford, the Medical Director of the College.

The local problem involved in the physical expansion of the College was not easy of solution. The village of Hanover had grown up around three sides of an open area known at different times as the "common," the "campus," and by official designation (vote of the Trustees, March 17, 1906) as the "College Green." "The title to this tract came to the College by grant from the Province in 1771, and by prior deed from Benning Wentworth, and had never been alienated." This tract of about four acres is in the form of a rectangle, almost a square, and is bordered on all sides by rows of stately elms. It is a fine level green, broken only by intersecting paths. Before the days of organized athletics it was used as the athletic field of the College, and is still a college playground, though kept as a lawn.

The college yard containing most of the college buildings lay directly across College Street to the east. The yard was the lower and more level part of the college park, a tract of about forty acres rising toward the north and east into a rocky ridge, on the summit of which stood the observatory. The question of the further physical development of the College was, whether it should utilize the park by means of a system of terraces, or whether it should seek to secure the requisite space by the purchase of the residential parts of the village adjacent to the Common. The matter was referred to Olmstead Brothers, the well-known landscape architects, who sent as their representative Mr. Charles Eliot, son of President Eliot, to make the necessary investigation. The advice based upon the report of Mr. Eliot was strongly against the use of the 
college park, for two reasons - the large expense of grading, especially in connection with any general plan of heating, and the æsthetic loss in converting so unique a possession as the college park to purely utilitarian uses, which might in the end prove insufficient. The college park had been made an object of rare beauty through the importation by Chief Justice Joel Parker, class of 1811, of foreign trees and shrubs which could be readily acclimated, and had been developed according to its natural advantages under the enthusiastic direction of President Bartlett. The stone tower bearing his name, which crowns the summit of the ridge, replacing in most timely way the "Old Pine" which had been struck by lightning, is a fit memorial, a reminder alike of his zeal and of his taste.

The alternative to the park plan, known as the quadrangle plan, which was adopted, was by no means inexpensive or otherwise free from difficulties. It called for the purchase of the entire residential property around the Common. Naturally the market value of the property responded quickly to the proposed change. Very properly too, the prospect of being dispossessed of their old-time homes was not welcome to many. Neither was it an altogether pleasing thought to those who were to carry out the process, to be the means of breaking up the quiet beauty of a New England village, even though offering in exchange the architectural effects of college buildings. It was, however, some relief that a break had already been made by business, and that two valuable estates had come into possession of the College, while a third was in the market. A beginning could be made in harmony with the general plan of expansion. Two things were kept in view as the process went on, the maintenance of the 


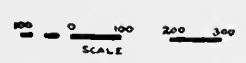

$\square$ Existing construction previous to 1893 .

Construction between 1893 and 1909.

Constructionsince 1909 .
MAP OF

\section{Dartmouth College}

HANOVER. NEW HAMPSHIRE

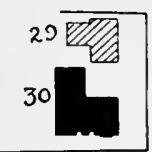

GREEN

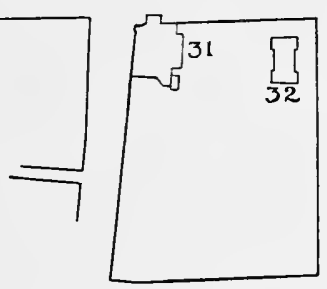

$\Gamma$

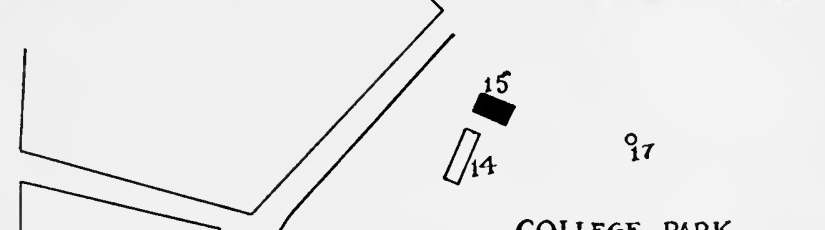

COLLEGE PARK

a

\&
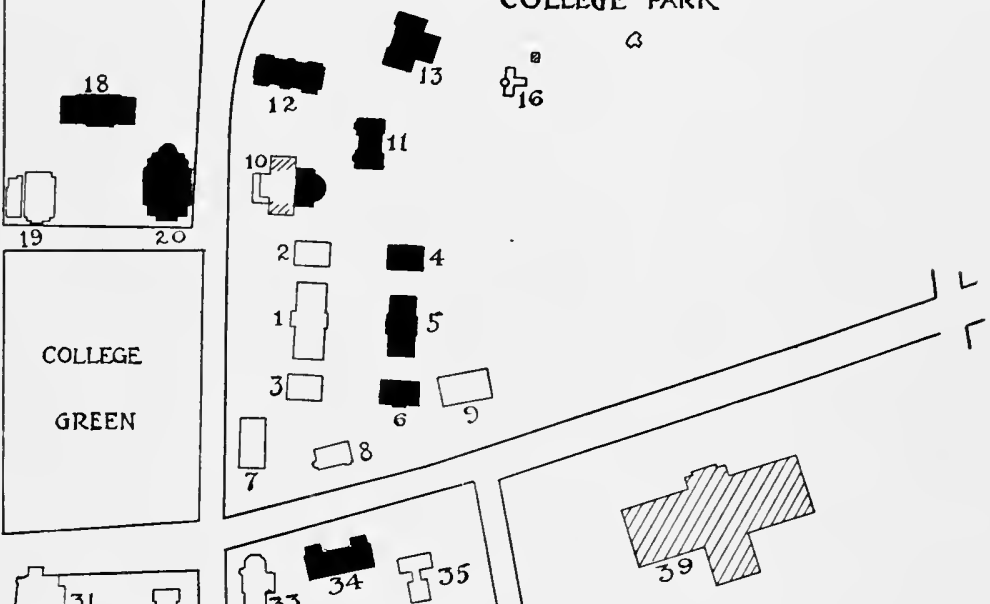

\section{KEY TO PRINCIPAL BUILDINGS INDICATED}

(With dates of construction and additions)

1. Dartmouth Hall, 1791. Rebuilt, 1905.

[structed, 1912 .

2. Wentworth Hall, 1828. liecon-

3. Thornton Dormitory, 1828. Reconstrueted, 1912.

4. North Fayerweatlier Dormitory, 1907.

5. Fayerweather Dormitory, 1900.

6 . South Fayerweather Dormitory, 1906. Reluilt, 1910.

7. Reed Dormitory, 1838.

8. Bartlett Hall, 1890 .

9. Culver I aboratory, 1870.

10. Rollins ('hapel, 1885, 1908, 1912.

11. Richartson I)ormitory, 1898.

12. Wliceler bornitory, 1905.

13. Wilder Laboratory, 1899.

14. Medical Building, about 1810 , $1873,1894$.
15. Nathan Smith Laboratory, 1908. 16. Shattuck Observatory, 1 s54.

17. Bartlett Tower, 1885-95.

15. Butterfield Museum, 1896.

19. The "College" Church, 1796, $1877,1889$.

20. Webster Auditorium, 1907 .

21. Crosby Dormitory, 1896.

22. Hitcheock Dormitory, 1913.

23. Hublard Dormitory, 1906. Moved, 1910.

24. Chandler Nathematics Building, 1791. Addition, 1898 .

25. Massachusetts Jormitories, $1907,1912$.

26. Parkhurst Administration Building, 1910.

27. Tuck School of Adninistration, 1904.
28. Sanborn Dormitory, 1895. Noverl, 1913.

29. Rolinson Student Builling, 1914.

30. College Hall, 1901.

31. The llanover inn. Reconstructed, 1902.

32. Thayer Fclionl of Engineering, 1866. Reconstructed, 1911.

33. Wilson Library, 1885.

34. New Hampshire Dormitory, 1908.

35. Hallgarten Dormitory.

36. Isolation Hosjital.

37. Heating Plant, 1898. Electric Ilant, 1905.

38. Store House and Shops, 1916.

39. Alumini Givmasium, 1910.

40. Alumni Athletic Field, 1893. 

proportionate amount of taxable property, and suitable provision for residential removals. For the latter purpose a new residential region lying to the north and west was made accessible through the opening of Webster Avenue and Occom Ridge.

The accompanying map shows the location of new buildings during the period of reconstruction. As will be seen, the pressure for room still remained in spite of the further use of the college park, and of the compact arrangement of buildings on the west side. Fortunately a new and most valuable tract was added to the college property through the assured transfer of the Hiram Hitchcock lands, extending from the Main Street of the village to the river, and comprising nearly forty acres. The negotiation was effected by Mr. Charles P. Chase, the treasurer of the College, who was also a personal friend and adviser of Mrs. Hitchcock. Too much credit cannot be given to the sagacity and tact of Mr. Chase in securing local advantages of great value to the College, particularly of the Hitchcock tract, nor to the loyal and public action of Mrs. Hitchcock in making this gift of the Hitchcock estate. Although the transfer of the property did not actually take effect till after the death of Mrs. Hitchcock in the year 1912, the negotiations as already effected in $\mathbf{1 9 0 8}$ gave the College the assurance of ample provision for all future plans of expansion. The College Green as the center of the college property was now flanked on the east and on the west by tracts of about forty acres each, each tract offering in its own way the finest possible opportunity for effective treatment - an opportunity already improved in part by the opening of the Tuck Drive through the Hitchcock estate. The pos- 
session by the College of these related properties gives an impressive unity to its development, leaving the valuable tract of pine forest to the north for public uses, under the joint control of the College and the Precinct of Hanover.

The architectural development of the College was a return to the original type. Dartmouth Hall had long been recognized as a choice example of the college architecture of the colonial period, of which the only other surviving examples of distinction were Nassau Hall at Princeton and University Hall at Brown. The more recent buildings at Dartmouth had brought in a variety of type according to the taste of the particular architect employed. It was determined that henceforth there should be unity of design in construction, and that the controlling type should be that of the colonial college, with such modifications as the necessary uses of any buildings might require. To insure this end, the work of construction, and so far as practicable of reconstruction, was entrusted to a single architect - Mr. Charles A. Rich, of New York, at the time of the firm of Lamb \& Rich. When the approach was made to Mr. Rich, the fact was not recalled that he was a graduate of the College, but this fact proved to be of great significance in the devotion and generosity of his labors. As the College took shape under his direction, the scope, the refinement, and the ingenuity of his skill became more and more apparent. It was a considerable distance in time from the restoration of the Crosby House to the production of the interior of Webster Hall, but the shaping hand was at all points the same.

"Improvements" and construction called for competent superintendence. The Trustees were fortunate in being able to commit this work in succession to two civil engin- 
eers, graduates of the College and of the Thayer School, to Mr. A. A. McKenzie, and after his death in 1904 to Mr. E.H. Hunter. In each case superintendence developed into constructive service. The heating plant and system was largely the result of Mr. McKenzie's industry and skill. The construction of the later buildings of the period was entrusted more and more to Mr. Hunter, to the marked advantage of the College in economy. A peculiarly skillful piece of engineering was the moving back forty feet of the stone apse of Rollins Chapel for the insertion, according to the unique design of Professor Keyes, of a choir with little chapels on either side - a design which added much to the interior perspective, and nearly doubled the capacity of the chapel. Further demands for superintendence arose in connection with the management of the Commons, after the erection of College Hall, and also of the Inn after the Trustees decided to take direct charge of it rather than to lease it. Mr. Henry N. Teague, just graduated from the first class in the Tuck School, was made Controller of the College Club, including the Commons, and Mr. Arthur P. Fairfield, a graduate of the class of 1900 , who had had successful experience in hotel service, was made business manager of the Inn. During the period of physical expansion the officers of administration were in the Lord House, at the head of the College Green, the former residence of President Lord. Parkhurst Hall, the present commodious administration building, the gift of Lewis Parkhurst of the class of 1878, was first occupied in 1911.

The educational expansion of the College necessarily adjusted itself to existing conditions. It meant in part the 
introduction of entirely new subjects like biology and sociology into the curriculum, in part the organization of unorganized or attached subjects like history and economics into departments, in part the disproportionate increase of the teaching force in some departments as especially in the modern languages, and generally an enlargement of the Faculty. More money naturally was expended for equipment in the direction of the sciences than in any other; but as a further and very definite part of the expansion effected came in through the relative place assigned to the new humanities, history, economics, sociology, and the newer forms of political science, the increase of expenditure here, both in equipment and teaching force, was relatively great. Taking the three sections into which the curriculum of the College was divided, - the Departments of Language and Literature; Mathematics and the Physical and Natural Sciences; History, the Social and Political Sciences, and Philosophy, - little difference appears in the expense of the first two groups; the first group costing somewhat more for salaries, the second for equipment. The third group represents about three fourths of the expense of either of the others.

The extension of the subject-matter of the curriculum enlarged the intellectual horizon of the College; so also did the introduction in considerable numbers of new men into the Faculty, many of whom were from other colleges. Of the one hundred and twenty appointments made to the academic Faculty during the sixteen years of my administration (the enumeration does not include the faculties in the Associated Schools), forty-eight were of graduates of the College, seventy-two were of graduates of other colleges. Classifying these appointments by grades: 


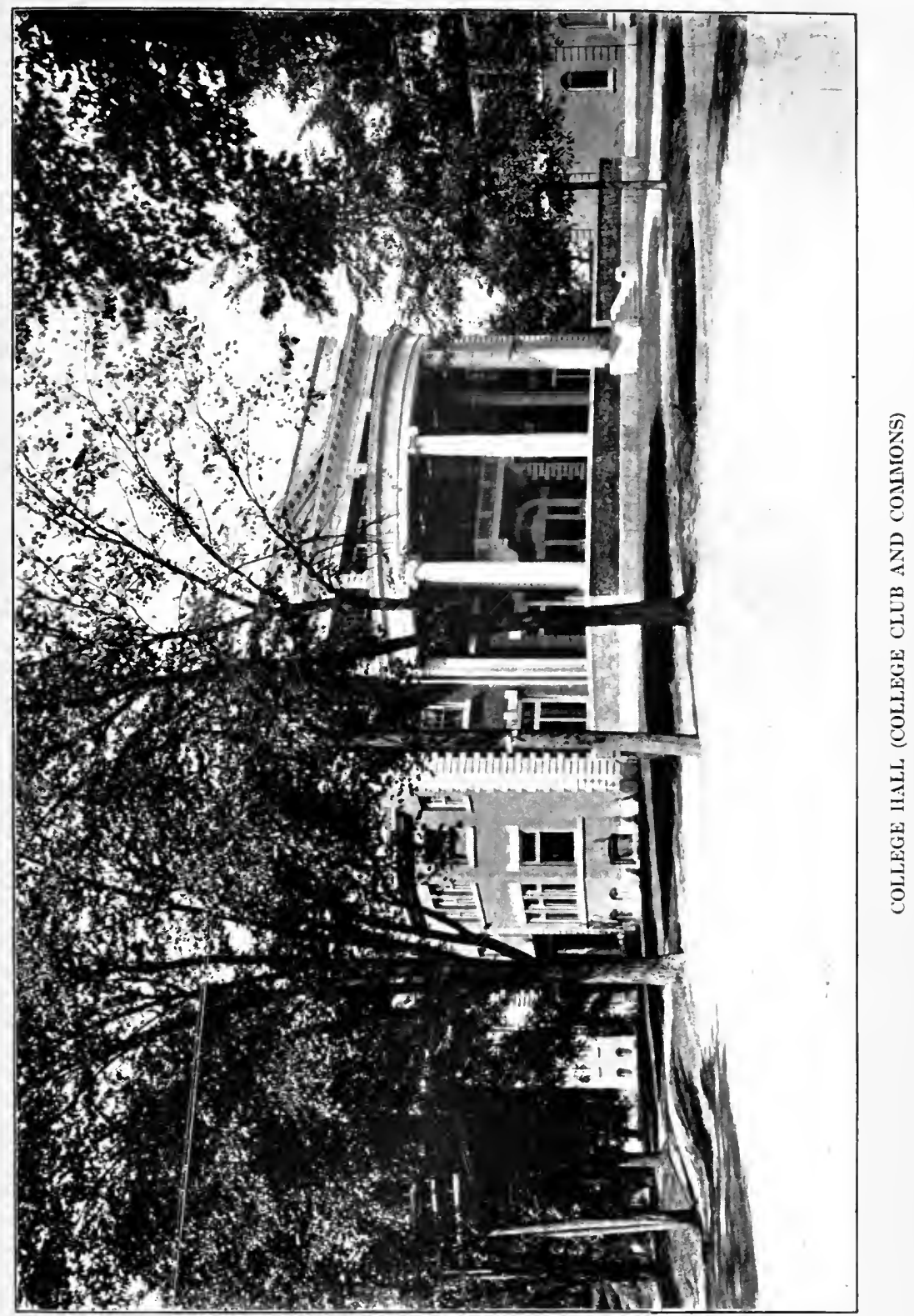


, 
To professorships, Dartmouth graduates............. 4

graduates of other colleges............. $12 \quad 16$

To assistant professorships, Dartmouth graduates........ $\overline{19}$

graduates of other colleges........25 44

To instructorships, Dartmouth graduates............25

graduates of other colleges........... $35 \quad 60 \quad 120$

The composition of the Academic Faculty at the close of my administration was:

Professors, Dartmouth graduates................ 14

graduates of other colleeges. . . . . . . . . . $12 \quad 26$

Assistant Professors, Dartmouth graduates............. 14

graduates of other colleges......... 14

Instructors, Dartmouth graduates................ 9

graduates of other colleges............... $10 \quad 19$

Thirty colleges and universities were represented by the bachelor's degree and twenty-four by advanced degrees. Trelve additional teachers in the Associated Schools gave instruction in the College.

Nowhere was the modernizing process more evident than in the changes it wrought in professional habits. No term, for example, would have been more unfamiliar, or in most cases unacceptable to the members of an old-time faculty than the term "office" as a substitute for the altogether congenial term "study." But the new buildings brought in offices adjacent to the classrooms, and the Faculty began to announce office hours. All the common activities associated with instruction centered in the office - that of the Dean, which soon added to itself the offices of registration. The advance in demands of this form of administrative service was rapid. When Professor Emerson was asked in 1893 to serve as Dean, it was with 
the understanding that he should retain his place as head of the Department of Physics. Within five years he found the combination impracticable and gave over, though reluctantly, his teaching, and shortly after Mr. Tibbetts, who had been his assistant, was made Registrar with his own assistants. Acting in harmony with this general tendency the Faculty proceeded to do its business more and more by delegating its powers to committees. Without doubt committee service is the bane of a professor's life; but most professors found themselves in this dilemma either to do the drudgery often imposed by the new task, or to be left out of the account in making up the new positions of faculty influence and authority. The advantage of committee service became more evidently desirable when the appointment of committees, even of the nominating committee, was given over by the President entirely into the hands of the Faculty.

The changes here noted could not have been effected without the ready and even hearty coöperation of the Faculty. Nothing, for example, could have been more delightfully helpful than the hospitality of the older members not only toward the incoming members, but also toward the new subjects introduced into the curriculum, and toward the new methods of instruction and administration. The utter absence of friction in the transition from the old to the new, or from simple to more complicated ways, was due entirely to the spirit of the Faculty, which was not that of acquiescence but of enthusiastic support. The hospitality of the older members was matched by the tactful adjustment of the incoming members to existing conditions, most of whom were strangers to Dartmouth. I recall those called to the headship of departments during 
the first year - C. D. Adams in Greek; D. C. Wells in Sociology; William Patten in Biology; H. D. Foster in History; F. B. Emery to a new professorship in English and next after, F. H. Dixon in Economics; E. F. Nichols in Physics; and L. H. Dow in French. The death of Professor Pollens, a man of rare linguistic and literary attainments, left the chair of French in a most necessitous condition at a time when large demands were being made upon it from the new position of the Modern Languages in the curriculum. It was quite impossible to repeat Professor Pollens's type - himself a native Swiss, educated in this country; and the graduate schools had not begun to do satisfactory work in the modern languages. In this dilemma Mr. Louis H. Dow, a classical scholar who had served for a year as a substitute in the Department of Greek, was asked to make his classical equipment a foundation for specialized training in French. The offer was accepted, with the understanding that he should have the right of way in reorganizing the French Department, a department which in 1908-09 was made up of one professor, three assistant professors, and five instructors. I cite this instance as an illustration of methods which happily came to the relief of the College at a time when there was a scarcity of men already prepared by special graduate training for the headship of new departments, or of departments under the pressure of enforced expansion. It was very fortunate that in this particular emergency the Modern Languages could be underwritten by the Classics.

While taking note of the changes attending the enlargement and reconstruction of the Faculty, it is of interest to note the change which took place in the student body, especially in the distribution of students according to 
locality. It will be seen how definitely the process of nationalizing the College had begun to take effect within the period of reconstruction. In the Catalogue of 1893-94 the registration stood by localities - New England, 427; Middle States, 34; Near West, 21; Beyond the Mississippi, 11. In the Catalogue of 1908-09 the registration stood New England, 839 (Massachusetts, 502, New Hampshire, 197, other New England States, 140); Middle States, 149; Near West, 98; Beyond the Mississippi, 48.

An amusing illustration of the tendency to generalize according to preconceived notions rather than according to ascertained facts, appeared in the comment of a New York daily on the success in the same year of the Dartmouth football team over those of Harvard and Princeton. The success was attributed to the physique of the men from the farms and lumber regions of northern New England. As a matter of fact the team for that year was made up chiefly of fellows from Western cities.

Foreseeing the exactions of the presidency on the administrative side, $\mathrm{I}$ had renounced in advance all hope of teaching. In this respect my course was in almost painful contrast, as I often felt, with that of one of my younger contemporaries - President Hyde, of Bowdoin - who was able in the midst of executive duties to make his chair of instruction a seat of power. As for myself, instead of assuming the teaching function $I$ did not hesitate to avail myself of the most valuable aids in my administrative duties. Professor John K. Lord was made Acting President of the Faculty in the absence of the President. This appointment meant much more to me than the freedom of often prolonged absences among the alumni. It meant the privilege of constant and most helpful advice. Later, and 


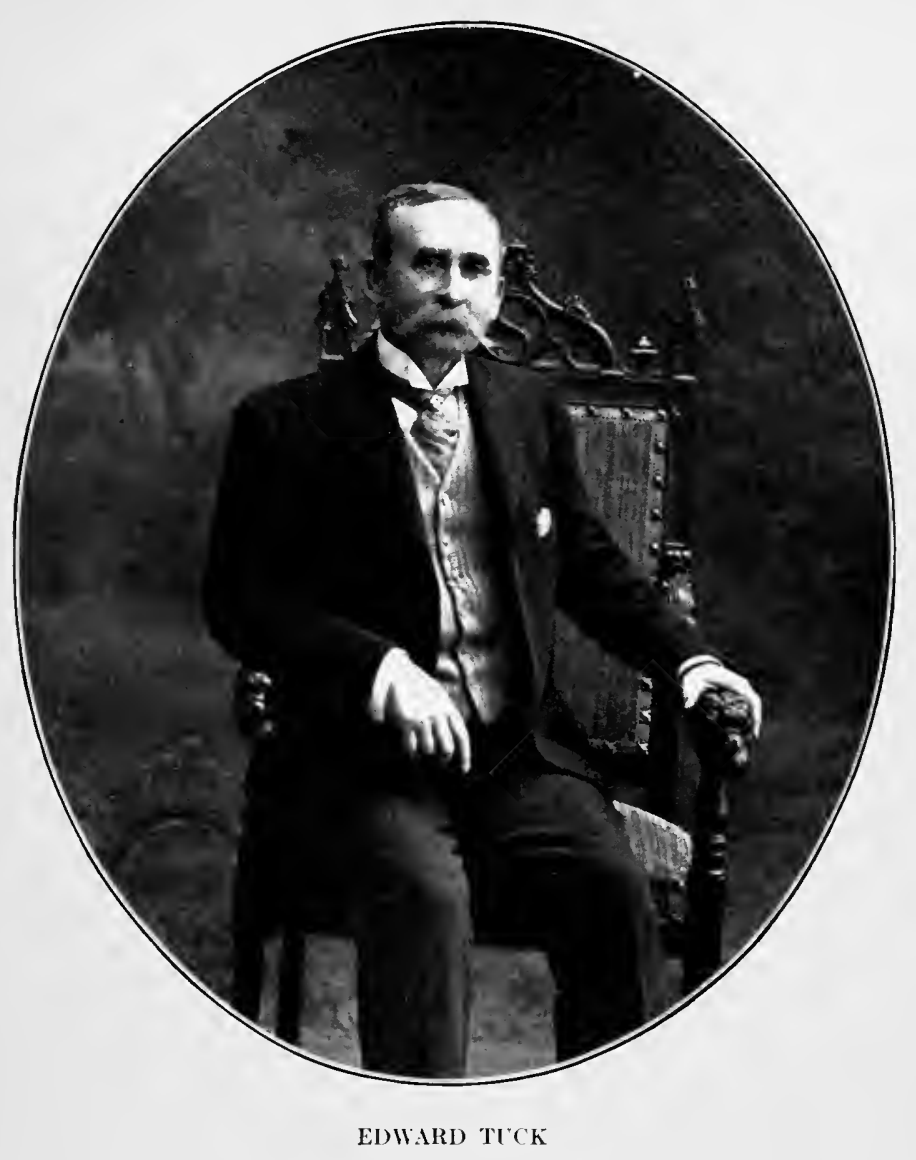





\section{THE DARTMOUTH PERIOD}

especially during the period of my illness while still in office, the promotion of Mr. Ernest M. Hopkins, who had been my private secretary, to be Secretary of the College, enabled me to relieve myself of certain definite responsibilities. The evidence of administrative qualities of the highest order gave the assurance of entire competency to meet the changed conditions.

About midway in the process of reconstruction, the College began to receive the aid of the benefactions of Edward Tuck of the class of 1862, then residing in Paris. I refer distinctly and separately to the coöperation of Mr. Tuck because of its timely significance. It was the most important individual factor in the reconstruction and expansion of the College. The amount of his benefactions, and equally their object gave security to the advances already made, and enabled the College in due time to take the initiative in a new field of academic training. They also gave direct moral support to the policy of the administration. Mr. Tuck was the first of the alumni of means to identify himself financially with what had begun to be known as the "New Dartmouth"; and his aid preceded any organized or collective financial support on the part of the alumni. It was the more gratifying and assuring that it was altogether unsolicited, indeed unlooked for. Mr. Tuck had spent most of his time abroad since his graduation. Appointed to the consular service in Paris the year after he left college, he passed directly from that service into the banking house of Munroe and Company; and although he was, during the greater part of his connection with the house, the head of the New York branch, he was at the time almost equally a resident of New York and Paris. After his retirement from the banking business 
in 1881, Paris became his permanent residence. His interest in the College was not developed by contact with its activities or by reminders of its needs.

The first intimation I had of Mr. Tuck's intentions came in a personal letter under date of October 21, 1898, in which he wrote that he had just seen in a New York paper that the Trustees were urging me to take "a leave of absence for rest and recuperation," and in which he urged me personally to put the leave of absence into a European trip, including a visit of Mrs. Tucker and myself in Paris. The letter enclosed a generous check to aid in carrying this plan into effect. It also conveyed the assurance of his very great interest in the recent work for the College, and intimated his own wish "to do something for Old Dartmouth." The letter of my old college friend was a happy reminder of our college days, especially as he wrote "of the winter term of 1860-61 when we roomed together" in the house now occupied by Professor George D. Lord; and the kind and urgent invitation fitted into the plan we had formed for a trip through the Near East. Upon our return from this trip we spent a week in Paris as the guests of the Tucks. I found the well-matured intention in Mr. Tuck's mind to establish an endowment fund in the College for the exclusive use of instruction. The fund was to bear the name of his father, the Honorable Amos Tuck, who graduated from the College in the class of 1835, and was a Trustee from 1857 to 1866 . The securities for the fund were already set aside, to be turned over to the College by his New York agent upon the acknowledgment of the acceptance of the fund by the Trustees. (The securities were put by Mr. Tuck at a minimum value of $\$ 300,000$, but as he foresaw, their cu- 
mulative value soon rose to $\$ 500,000$, at which amount they stand on the Treasurer's books.) There was no suggestion or implication of further gifts, but within a year the establishment of the Amos Tuck School of Administration and Finance, of which I shall have more to say in its place, brought additional funds for building and library. And it is proper to state here that at the beginning of the administration of President Nichols, the original amount of the endowment fund $(\$ 500,000)$ was duplicated, followed by successive gifts of various intent, and that during the opening years of the administration of President Hopkins, though these have been coincident with the disturbed and disturbing conditions of the War, Mr. Tuck has not lost sight of the College in the midst of his patriotic devotion to the common cause of France and America in the War. ${ }^{1}$

The financial coöperation of the alumni as a collective body passed through three stages. Strictly speaking it anticipated the organized reconstruction of the College. It formed a part of the movement of the alumni for representation; the promise of it was in fact made an argument for granting their request. It had to do in this initial stage with the advancement of athletics as a part of a larger plan for the physical development of the College. The immediate result did not reach beyond the preparation of the ath'etic field known as the Alumni Oval, but the ultimate result was the construction of the new gymnasium. The second stage was the response to the appeal for the replacement of Dartmouth Hall when destroyed by fire, made by a committee of which Melvin O. Adams of the

1 At the Commencement dinner of 1919, President Hopkins, in announcing recent gifts of Mr. Tuck, said that the total of his gifts to the College in the past twenty years amounted to over a million and a half dollars. 
class of 1871 was chairman, a response which carried with it to a successful issue the hesitating movement for the building of Webster Hall. Although the corner stone of Webster Hall was laid at the Webster Centennial, 1901, the building was not completed till after the rebuilding of Dartmouth Hall in 1905. The third stage has been that of organized effort for continuous and permanent results. This effort has already resulted in the financial coöperation of classes, and in the beginnings of a general fund to be made up by annual contribution of the alumni at large, a part of each annual contribution to go on deposit, and a part to be put at the disposal of the Trustees for current uses. The fund was devised by Mr. H. H. Hilton, of the Board of Trustees, in 1907, after the general scheme of the Yale Alumni Fund, and does me the honor of bearing my name. The more complete organization of the alumni has added greatly to their usefulness to the College. The Association of Class Secretaries, founded by Secretary Hopkins in 1905, has become a very influential body; and still more perhaps the Alumni Council, due to the same organizing source, now recognized as a most valuable although unchartered auxiliary to the Board of Trustees.

The period of reconstruction, as defined by the Trustees, financially covered twelve of the sixteen years of my administration - 1893-1905. During this period the draft upon the fund which had been set apart to meet the succession of annual deficits amounted to $\$ 169,476.89$. For the remaining four years there was an annual surplus appropriated in part to the recovery of minor funds, and in part to current improvements, as in the remodeling of the interior of Culver Hall, and in the first enlargement of Rollins Chapel. Meanwhile the earning power of the Col- 


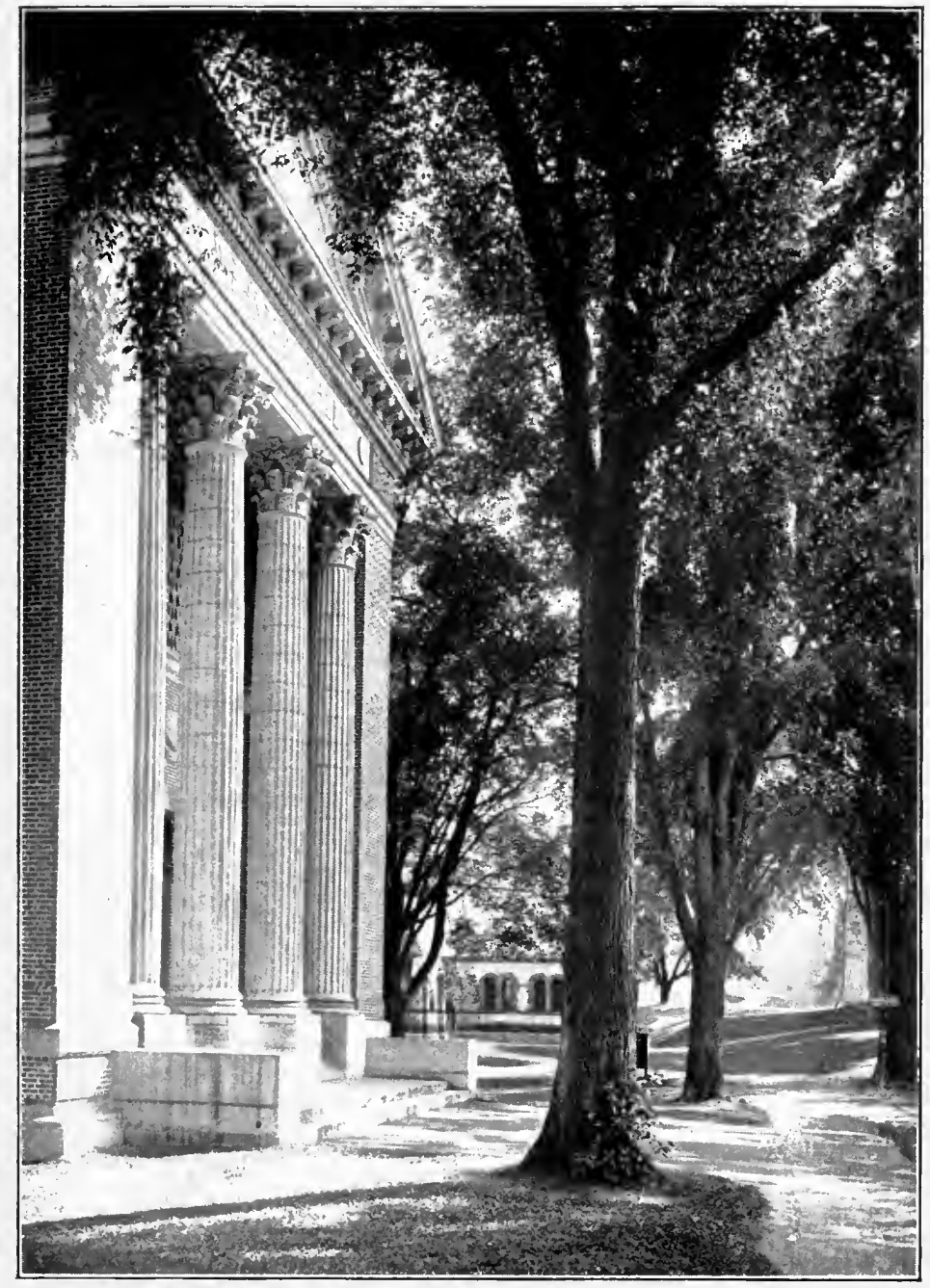

WEBSTER HALL 


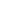


lege, estimated in the return from tuition, had increased from less than $\$ 20,000$ net in 1892 to over $\$ 120,000$ net in the years 1905-09.

I said at the outset of this section that it was one object of the general policy of reconstruction and expansion to test the normal capacity of the College. At the close of my administration it was found that the normal capacity of the College, measured by the increase of faculty and students, by the enlargement of its facilities for instruction, and by the extension of its endowments, had increased threefold. ${ }^{1}$ That this was no abnormal increase was proven by the fact that under the more intensive administration of my successor, President Nichols, the normal capacity, measured by the same standards, showed a fourfold increase. With this fourfold increase of capacity the College, under the strong and timely leadership of President Hopkins, was able to put itself at the service of the Nation.

\section{IV}

\section{The New Morale}

The external changes brought about by the modernizing process were soon apparent, but their effect upon the internal life of the College could not be quickly seen or easily estimated. The effect, for example, upon scholarship was for some time in doubt. On the whole the immediate effect was not favorable. The inherited scholarship of the classroom was the resultant of well-formulated sub-

\footnotetext{
1 For a general statement regarding the endowments and resources of Dartmouth, see series of articles in Dartmouth Bi-Monthly for 1907-08 discussing the resources and expenditures of the College, collected into a pamphlet. For a later exhibit of the properties of the College see Manual of Charter and Documents, by Judge William M. Chase, Clerk of the Board of Trustees, 1911.
} 
jects, of a logical routine, and of a compulsory discipline. All these conditions were changed to the degree in which the new régime took effect. There was a manifest immaturity about the new subject-matter as seen from the point of view of the classroom. Students entering college by way of the new subjects were relatively ill-prepared. Instructors in the sciences very much preferred for their classes those who had entered for the A.B. degree. The new courses appeared fragmentary when compared with the routine long at work in the classics and mathematics. And the elective system called for a sudden shift of will power from the college authorities to the individual student. There was, of course, much stimulus to scholarship latent in the new subject-matter and in the principle of the elective system, but the interruption of the college discipline was felt earlier than the stimulation of the new freedom.

If any one had assumed that the modernizing process was to be altogether an intellectual process, he would soon have been convinced that it required for its success strong moral supports from without, and the utilization of the moral forces within the student body. The uncertain but really decisive factor in the whole matter was the student himself, involving his moral quite as much as his intellectual attitude. What would his response be, or, if one may still be justified in recalling the overworked and outworn term of the new psychology, what would be the nature of his "reaction" under the process? The dominant characteristic of the New England, certainly of the Dartmouth student of a generation ago was his independence. Sometimes this independence showed itself in a certain aloofness from more serious college affairs, and on occa- 
sions in positive antagonisms. But it was the most valuable quality which he possessed, estimated even by its educational use, and was to be preserved at the cost, if necessary, of the liabilities to which $I$ have referred. But why should these liabilities be accepted as necessary? Why should not this prime quality of independence be transformed into a larger self-respect, and informed with the spirit of responsibility? From the first I believed in the incorporation of the students, individually and collectively, into the movement for reconstruction and expansion. I believed that it was entirely possible, as it was certainly in every way desirable, that they should be made to share in the "corporate consciousness of the College." To the degree in which they understood and felt this larger consciousness, they would be qualified to take a leading part in remoulding college sentiment as a means of reaching and applying higher standards. With this end in view, I sought to interpret the history and traditions of the College in their relation to present plans. The graduates up to 1898 will recall a weekly exercise known as "Rhetoricals" held in the Old Chapel, attended by the whole College - a somewhat unruly exercise open to various liabilities, but affording a rare opportunity of indoctrinating undergraduates into the permanent duties and responsibilities of the college fellowship. When this exercise was abolished through excess of numbers, "Dartmouth Night" was instituted, to bring the undergraduate body intc sympathetic and intelligent contact with the alumni, the living and the dead. The portraits of the more illustrious of the early graduates, hung for the occasion on the walls of the Old Chapel, and later permanently vivifying the walls of Webster, gave a reality to the men and events 
of the past, comparable to the effect of the presence and the voice of the living graduate of like distinction. Through the suggestion of President Nichols in the observance of the custom in his administration, "Dartmouth Night" was made the occasion for gatherings of all the graduates in all the Associations throughout the country and abroad. The "Night" was marked by the exchange of greetings between these widespread and remote gatherings and the gathering at the College.

The response of the students was prompt and hearty in all ways of external aid, especially in the effort to nationalize the constituency of the College. It was the students who carried the College into the Western cities and over the Mississippi. This coöperation required, however, only an intelligent enthusiasm. A much deeper test was to come in the education and control of college sentiment. Here there was need of reform, especially in the matter of the survival of certain college customs which had become demoralizing and obstructive. The test at this point soon came, as was to have been expected, in the natural course of college life. The result was so significant as to warrant a somewhat detailed reference. There was an old custom, reaching in fact back of the memory of most living graduates, known as the "horning" of instructors, who had for any reason wakened the wrath of the student. It was the accredited method of disciplining the Faculty. I do not know whether it obtained in other colleges or was altogether a local habit. But whether supported or not by general college usage, the time had come for its abolition at Dartmouth. When the custom first came under my official notice, I did not treat it in the way of discipline, but as a fit subject for the exercise of college sentiment. I fully 
explained its relation to the general college life, showing how vitally it concerned the spirit of the whole college fellowship, and making clear its absolute inconsistency with the social progress of the College. I had no way of measuring the impression produced by this view of the matter, except by the length of time which elapsed before the recurrence of a "horning." It so happened that at the time of its recurrence, I was absent from the College on a trip among the alumni. I had just left Washington for Chicago, when I received word of the outbreak of the custom in somewhat aggravated form. I canceled further engagements, and, returning instantly and unexpectedly to Hanover, began at once a quiet but thorough course of investigation. It had been a class affair, and every man in the class was asked directly about his part in it. No one was asked what any other man did. As a result of the investigation, the self-convicted leaders in the affair were separated from College for longer or shorter periods. The penalty of "separation" was chosen to express the single idea that any student who, under the existing conditions, and in face of the appeal which had been made to college sentiment, chose to uphold in his own person the insulting custom at issue, did not really belong to the college fellowship, so long as he upheld the view which allowed him to indulge in the practice. The action, though considered somewhat drastic - far less so by the students than by many of the alumni - was not considered by the students unjust or uncalled for. There was, however, a certain feeling among them that the penalty was unequal in its application, a feeling justified by their more intimate knowledge of the relative part taken by different actors. In view of this knowledge, they asked of the Faculty, 
through a committee, that the investigation be reopened in the hope of a reduction of some of the penalties. To this request the reply was made that further consideration would be given, provided meanwhile the College would consider, and discuss, and declare itself in reference to the continuance of the custom, accompanying this action by careful study of methods of satisfying grievances and complaints. This proposition was accepted in serious spirit, and for over a week the subject was fully discussed in fraternities, classes, and finally in a series of mass meetings of the College. As a result, resolutions were unanimously adopted committing the College to the abandonment of the custom, and providing a proper substitute for it. When this position had been fairly taken, the request for a change of penalty was met, not by the reduction of it, but by the removal of it; and each student who had been separated was permitted to resume his place in his class, upon conforming to the now organized college sentiment. College sentiment had come in to take the place of college authority. For the college authority to have perpetuated itself under the conditions would have been irritating and ungenerous. The end of discipline was not the separation of offending students, but the casting-out of an offensive custom, and the exorcising of the spirit which informed it.

The action of the student body at this time constituted one of the most honorable and decisive episodes in the history of the College. Its effect was permanent and cumulative. I remember saying to Dean Emerson some years afterwards, when some incident brought back the episode, that if there was any justification of the term, the "New Dartmouth," it came from this advance in the tone of college sentiment, rather than from any progress in the 


\section{THE DARTMOUTH PERIOD}

external development of the College. One outcome of this action was the organization of a society, the aim of which as announced was "to bring into close touch and harmony the various branches of college activities, to preserve the customs and traditions of Dartmouth, to promote her welfare and to protect her name." The society took the name of Palæopitus - the rendering in Greek of the Old Pine, around which gathered the earliest traditions of the College. At first the society was secret and self-perpetuating, then the secrecy was thrown off, and later it was given over to the upper classes for the determination of its membership. Though entirely unofficial in its action, it merits the statement of the "Alumni Magazine" that on the whole it represents "the conscience of the College at work."

In dealing with an academic democracy, whether personally or officially, one has constantly to keep in mind the fact that the democratic spirit is less hostile to the idea of discipline than to the idea of conformity. Democracy does not easily adjust itself anywhere to the social conventions, doubtless because of their inherited association with rank or caste. And yet democracy is not Bohemianism. It is in no sense the cult of the unconventional. It lacks altogether the charm of the unconventional, when the unconventional takes on an unaffected alliance with nature or with art. Democracy, however, has its own conventions, among which is the obsession in some minds that if it is to retain its character it must abide within strictly primitive conditions.

It was inevitable that the modernizing process, as applied to the physical reconstruction of the colleges would bring them into more direct contact with the ordinary 
social conventions. The same forces which were at work creating new conveniences, comforts, and even luxuries compared with former necessities, in private and public places and among all classes of people, were at work in the colleges. The modern dormitory was simply the modern home adapted to academic uses - furnished adequately with water, heat, and light, and kept in sanitary condition by proper service. The chief innovation in both cases was the invasion of the old order by the bath. The daily bath, or at least the opportunity for it, caused a general leveling-up of society. It removed some arbitrary but very separating distinctions. The bath in time created its own routine to which it exacted a certain loyalty. Professor Arthur Sherburne Hardy used to quote an old countryman in these parts, whose late experience of the bath had resulted in more loyalty to the idea than familiarity with the practice, as saying, "I will have my bath once a year whether I need it or not." The bath came to mean much more than cleanliness, not so much more as to the Romans, but still much and in various ways. A college was not the same before and after the institution of the "Order of the Bath." I am free to confess, however, that there were at Dartmouth occasional lapses from the new order, and not a few inconsistencies and antagonisms. I recall, for example, the invasion of the sweater at the time of its most flagrant ugliness - an ugliness so flagrant that I was obliged to make a ruling to protect the decency of the chapel service, that it be excluded or covered.

To some minds the modern dormitory was the unmistakable sign of the incoming of luxury. So it appeared to some of our older graduates, jealous for the old-time guarantees of the democracy of the College. I recall two 
of these especially, both men of ample means and one certainly of the amplest culture - Dr. John Ordronaux. Dr. Ordronaux was a most delightful visitor at Hanover, when he came annually on his tour among the medical schools as Lecturer on Medical Jurisprudence. I think that each new dormitory with its sanitary equipment was an offense to him, and evoked the most strenuous denunciation that his unequaled command of Latin derivatives could supply. I never failed to avail myself of the intellectual treat which followed when once he caught sight of the modern Sybarites who dwelt in the modern dormitory. Very generously, but not quite consistently, Dr. Ordronaux left a "Good Samitarian fund" to the value of $\$ 30,000$ for the benefit of professors longest in service, who had experienced the early privations of college life. The other graduate to whom I have referred, after visiting Hanover by invitation of one of the Trustees with a view to a bequest, flatly refused the suggestion of his friend. The bequest, which was made known soon after, was most worthily, but as it evidently seemed to him much more fitly, bestowed upon a woman's college, which at the time was passing through an almost identical modernizing process in its building programme with that at Dartmouth.

In course of time it came to be seen by all that, beyond insuring safety and sanitation, the dormitory system had a direct effect upon the morale of student life. It equalized social conditions. As administered at Dartmouth, every dormitory provided rooms for poorer students with access to the same general conveniences. ${ }^{1}$ There were no dormi-

1 The last two dormitories built during my administration, Massachusetts (1907), and New Hampshire (1908), represented the possibilities of the modern dormitory for equalizing conditions, allowing all occupants to share alike in the conveniences common to the higher grade of dormitories. Each dormitory cost 
tories set apart for students on scholarships. Dormitory life became a training in academic democracy, in the process which I have described as leveling-up. College Hall a college club including commons - was built as a complement to the dormitory system, to carry out the same democratic principle and to insure its acceptance. The fraternity idea was not discouraged, but by the ruling of the Trustees no fraternity house was allowed to accommodate more than fourteen members - about one third of the usual membership; and, though there was no rule against separate tables at the fraternities, the spirit involved in the ruling on rooms has been carried over by the fraternities for the protection of the common college democracy.

The adjustment of college life to intercollegiate athletics, having in view the effect upon the college morale, was a difficult and at some points a most vexatious problem. "Nevertheless," as Mr. Beecher used to say when confronted by the results not altogether to his liking from policies which he advocated, I accepted athletics as a legitimate factor in our educational life. To my mind, the Greek settled that question decisively and passed on the principle to us through our English antecedents. I have never been able to see the moral equivalent of organized athletics. The alternative is recreation; but recreation is no substitute for athletics, because athletics is in no sense a recreation. Athletics is a game, a contest, and means all that is implied in these terms - adequate training, stim-

about $\$ 80.000$, and each accommodated about 100 students - Massachusetts 88 , New Ilampshire 107. The average rental per man in each of these dormitories was $\$ 100$, but the rental was so distributed in gradations of $\$ 5$, from $\$ 65$ to \$135, that one hundred and eighteen occupants of the two dormitories paid less than $\$ 100$ each, six paid $\$ 100$ each, and seventy-one paid over $\$ 100$ each. 
ulating antagonism, and a considerable degree of publicity. But these in turn imply a coaching system - presumably a professional though academic coach, college rivalries, and the exploitation of the press. These are all serious liabilities. They cannot be ignored, or overlooked, or minimized. "Nevertheless," to return to my quotation, I held fast to my educational belief in athletics during a somewhat stormy period of discussion, substantially for the moral possibilities rather than the physical results to be gained. I have always been doubtful of the value of the physical results, especially to the most highly trained athletes.

My reasons in support of athletics, stated more definitely, were, first, I regarded athletics as a legitimate school for training in leadership. "Leadership," as I have elsewhere said, "grows out of the combination of personality and attainment. The proportion of personality to attainment varies greatly, but neither one is sufficient of itself to make a leader. The loafer cannot become a leader, however agreeable he may be personally. The athlete cannot become a college leader if he is not essentially a gentleman, with some recognizable intellectual force. When the scholar fails to reach leadership, as is so often the case, having presumably attainment, the lack is somewhere in those personal qualities which make up effective personality authority, virility, sincerity, sympathy, manners."

Without doubt the personality of many athletes enters to a considerable degree into their influence over their fellows, but their chief claim to leadership lies in the field of attainment. This fact must not be overlooked in estimating the value of academic athletics. If the athlete seems to compete with the scholar, it is because he represents 
much of the discipline which scholarship requires. He is of no account till he reaches a given standard of excellence. Further, it must be remembered to the credit of athletes that it has introduced the idea of excellence into what is known as college life. It has literally projected this idea into an otherwise loose, flabby, unmotived life of the undergraduate. It compels a different standard in all college activities, even those of a more intellectual cast dramatic, journalistic, artistic. The amateur undergraduate has been obliged to conform to a different standard of college opinion, if he wishes recognition outside the rewards of scholarship.

A second reason for my respect for athletics was the beneficial character of its democracy, - no more marked, of course, than that of the classroom, but on an equality with it. The one and only inexorable test in either case is attainment, excellence. It puts the man relying solely on personal effort on the level with the man who has some inherited advantage. It gives a man who is not of the highest scholarly aptitude the self-respect and courage of being able to do something well, something of recognizable value. I think that the loss of this privilege would on the whole lower the tone of college life.

And a third reason, a reason which at least held my serious attention to athletics, was the constant succession of moral issues involved in the management of intercollegiate athletics. Athletics occupied the territory nearest the frontier line between the colleges and the outer world. It was as easy to cross this line from without as from within. The task of an athletic committee was unique among college committees, requiring always intense watchfulness and at times stubborn resistance. The in- 
vasion of commercialism was dangerous because of its sophistries. It had its propaganda well prepared to meet college conditions. Perhaps the most conspicuous was the argument for the employment of college baseball teams at summer resorts, namely that it was proper to capitalize one's college athletic reputation; not to do this was a manifest waste and needless deprivation for poorer students to endure. Here lay the special peril of college athletics, through the relation of one branch to a public game which had a well-defined market value. To such an extent had this peril become a reality in the academic world that I felt constrained to devote a paragraph to the subject in one of my opening addresses on the assembling of the College. "Apparently," I then said, "the temptations to evasion or deception, or to open surrender to commercialism in connection with baseball are too strong to be resisted. The academic player has not been able to maintain his separateness, his distinctness from the professional player. More demoralization, in my judgment, has come into college life from the commercial seductions of baseball than from all the liabilities of any sort inherent in or associated with football, the one really great and distinctive academic game. If this demoralization continues, I am prepared, as a lover and defender of college athletics, to advise the elimination of baseball as an intercollegiate game from college sports. I would confine academic sports to those games which have no such well-defined market value, unless we can make the price we pay, and which we do pay most liberally, a sufficient reward - namely college honor."

It gave me much gratification to be able to say the following year, as a result of the action of the Athletic 
Committee, entirely on its own motion, by which the college baseball team that had played under an engagement during the summer season, had been debarred from a place in intercollegiate contests, with the acquiescence not only of the College but of the team itself, "I wish to congratulate the College upon the way in which during the past year it has, in a collective sense, played the gentleman. In your action in regard to summer baseball you took what you regarded as the position of honor at the risk of defeat. The fact that your action brought you success does not detract from the honor due you; and in this honor none are more deserving of recognition than those who generously acted with you to their own disadvantage. This college has not seen a finer example of undergraduate loyalty than was shown by the men who gave their effective support to the team from which they had been debarred." The incident here referred to serves to illustrate a certain moral discipline which may inhere in the management of intercollegiate athletics. It is not to be overlooked in any just estimate of the athletic situation at a period when it was, with reason, most suspected of commercialism. As the situation developed it cleared itself more and more of questionable practices. When alumni, five years apart in graduation, discussed the athletic situation, the moral argument was almost invariably with the younger alumni. Looking back upon this general period, I think that the undergraduates who passed under the strain and discipline of intercollegiate athletics, came out with a better preparation for meeting the conditions of the outer world than those who, for fear of intercollegiate liabilities, were restricted to intramural athletics.

I have said that the elective system was the new and 
important factor introduced by the modernizing process into the general college discipline, the result of which might be expected to appear in the effect upon the college morale. I have also said that the immediate effect was not favorable to scholarship, but rather disturbing, partly because of the immaturity of the subjects which came in with it, and partly because of the unpreparedness of most students for the larger freedom which it prescribed. It presented itself to them with the apparent inconsistency of a compulsory freedom. In due time, however, a radical change took place both in the apprehension of the new subject-matter and in the use of the new freedom. As the new subjects came under academic appraisal, they were seen to have a distinctive value or values which added to the sum total of the college discipline. If the college discipline was to be understood as set to the task of developing the art of thinking, here were subjects which called for perhaps the finest exercise of the art - the art of interpretation: history, for the interpretation of events, sociology for the interpretation of human society, and economics for the interpretation of those values which are the product of human invention and labor. History naturally led the way in training for this art. This was its high function, not the commitment of information, however well ordered or however necessary for general uses, to the guardianship of the memory. Biology took its place beside the older sciences as a most efficient ally in enforcing the necessity of acquiring the habit of responsible thinking; but it also required in large measure the interpretative faculty. The problems of physical life reach beyond the experiments of the laboratory, just as the problems of human society and of human activities reach back into 
the investigations of social research. I followed while in the College, and have followed since with great interest, the monographs put out from time to time by Professor William Patten, in which he has carried over the results of his experimentation into the inviting field of interpretation. On the whole the effect of the new subject-matter upon the mind of the College was invigorating and wholesome. It tended to produce more intensive and responsible thinking. The effect was wider and deeper than could be measured by the ordinary tests of scholarship. It was difficult to rate it in the terms of the marking system. The solution of a problem in mathematics is right or wrong, and can be so recorded with due allowance for mistakes which do not really inhere in the process; and so in almost equal degree is the answer to a critical question in the classics. It is more difficult to weigh the evidence of the grasp of a subject, or of its practical or philosophical application, in the thought of a student. What is often apparent, however, is a certain cumulative effect of a subject upon the student himself. The test really comes within the category of morale.

The elective system itself needed considerable modification to enable it to realize its moral intent. As a system of unrestricted freedom it was liable to misuse and to over-use. It might be used to evade the harder subjects, or in the interest altogether of vocational subjects. One might wander at will amongst the elementary courses, or one might take a straight and narrow path to some professional end. Certain restrictions were necessary to give the system its proper effect: one, the retention of some compulsory elementary courses; another, the arrangement of the curriculum in groups of subjects which must 
be recognized in the choice made; another still, the requirement that one must reach advanced standing of high grade in a certain number of subjects in order to receive a degree. These restrictions and requirements coupled with one's personal choices out of the general curriculum, became a matter of no little study in itself. To a scholar, it was an invitation to take the best the College afforded. To the average student, it was a summons to gird himself for the essential business of a college man. When the system failed to awaken the natural interest which might have been expected, it remained still a challenge to the will to assert itself. When it failed to awaken interest or arouse the will, it failed altogether and had no advantage above the system of compulsory discipline which it had displaced, if indeed it reached to that academic level. Incidentally, it may be said that the elective system did much to develop a natural intimacy between instructors and students. Students elected instructors as well as subjects, in some cases preferably the instructor. But in either case, the instructor had the right to assume that, so far as the election was free and open, the men before him were his men with whom he might enter into a sincere academic friendship.

In contrast with the work of an instructor, the work of an administrative official seemed impersonal, and so it was to me, in spite of the fact that on occasions the president could come into closer and more intimate relation with students than the faculty or any member of it. I had anticipated and had tried to discount this more impersonal character of administrative work; still I was so far unsatisfied with the practical result that I determined to find some legitimate way of free access to the "mind of the 
College." I regarded this phrase of Dr. Jowett of Balliol as the most significant of all purely academic designations, whether applied to the college in a collective sense, or to emphasize its intellectual distinction. The one opportunity at Dartmouth within reach of the President for definite and constant access to the mind of the College lay in the use of the chapel service, which by tradition fell to his lot. Could this service be made to satisfy the desire for as distinct and well-defined a contact with the student mind as could be made through the classroom and the curriculum? In one respect, it had manifestly the advantage; it gave access to the student body as a whole and could be utilized in the interest of college unity. But how about the possibility of reacting through it into the deeper and more individual workings of the college mind, of meeting its more personal necessities, of interpreting men to themselves? I resolved to find the answer to this question in the treatment of the Sunday Vesper Service in Rollins Chapel; and for the sufficient test of the answer, I allowed no engagement for Sunday to interfere with this fixed engagement. I resolved also that except in cases where some consecutive treatment of a subject was necessary, each service should have the freedom of subject to which it might seem to be entitled. It remained only that I should hold consistently to certain objects which, though personal and unannounced, should guide me in the conduct of the service and in the choice of subjects. The time allotted in the service for direct address was fifteen minutes - an allowance which I determined should not be exceeded, regarding adherence to it to be as much a matter of intellectual discipline on my part, as of honest conformity to academic limitations. The honesties which inhere in the 


\section{THE DARTMOUTH PERIOD}

use of time are taught and practiced more faithfully in the classroom than in the pulpit.

I did not assume in this determination to gain access to the mind of the College, that I had the full understanding of it. It was to be a matter of continued study; but I was quite sure of the fact, since stated with fine discrimination by President Lowell, that "college work may affect the fortunes of a life-time more profoundly than the studies of boyhood or of the professional school, but the ordinary student does not know it." This unrealized meaning of the college discipline is a state of mind to be recognized but not accepted. Full realization may not be expected and premature realization is not to be desired, but the process of self-realization in and through the environment of the College is a part, and a very important part, of the process of education. The work of the College in all of its departments tended, of course, directly or indirectly to this end; but as I saw the situation, there were definite points of which the classroom could not take cognizance or upon which it could not lay sufficient emphasis. It seemed to me to be necessary, as a complement to the work of the classroom, that there should be some direct and authorized endeavor to stir up the mind of the College to the understanding of the meaning of its own personality, individual and collective; to keep its mind open and sensitive to that human world of which it was a part, though for a while detached, that in due time it might enter more fully into its life; and also to give the mind of the College some vision of that larger environment, whose boundaries are discernible and accessible to faith. In other words, there was need of some agency in and of the College which should pursue in all fitting variety of form the one object, 
to interpret and quicken the sense of the personal, the sense of the human as felt in the life of the world, and the religious sense. As the situation then was at Dartmouth, this specific task fell, as I have said, to the lot of the President, and I accepted it as an opportunity not to be set aside.

In accepting it, however, in this light, I recognized clearly the fact that there were certain characteristics of the college period which were to be accepted with it, and were in no case, even when their liabilities were most evident, to be disregarded. In fact they were, as I regarded them, rather the necessary conditions of fulfilling the college function in the educational system. The first of these conditions was freedom - freedom as understood elsewhere and in other relations. This condition applied especially to the development of personality, where on account of the transition of the average student from a previous stage of restraint, the temptation was at times great to continue the process of repression. I found it necessary to keep constantly in mind the fact that there could be no awakening of the mind to the real meaning of personality, without a quickening of the sense of personal power; and further, that in this quickening of the sense of personal power, lay the chief safeguard of freedom of thought and action. It also seemed necessary to make clear to the student mind the distinction between the development of individuality and the development of personality the former the measure of the difference between one man and another or between one and the many, the latter the measure of the fullness of one's own nature. This alone when realized, as I sought to show, is the distinction of all true greatness; this individualizes the really great man 
and makes the essential difference between him and other men.

In "Personal Power," published after my retirement, I gathered up a considerable number of sermons and addresses, in which the spirit and aims of the chapel talks were embodied. This volume was not at all a reproduction of the chapel talks, for these were entirely informal, but a more formal expression of the same purpose and method which had guided me in the attempt to develop the sense of personality in the college man.

1 Next to the development of the sense of the personal, I put the development of the sense of the human, the sensitive consciousness, that is, of one's part in the life of the world. But here again it was necessary to have regard to a characteristic of the college period, in some respects contradictory in its effect, namely, a certain formal detachment from the more responsible and burdened life of the world. This detachment was a recognized condition of the college discipline to insure the command of time, and necessary to give the right perspective through which to view the world. It implied the possibility not only of seeing things in their proper relations and proportions, but also the possibility of looking upon them with a mind freed from passion and prejudice. But to offset the manifest danger from this detachment, there was need of holding the mind of the College in serious contact with its larger human environment. The thought of the average student about the world is quite irresponsible. He turns to the outer world for amusement, or if he is poor, for aid to selfsupport. Otherwise his personal interest is limited, and seldom passes over into any form of concern for its welfare. Of course, the immediate and perhaps more permanent 
loss from any such intellectual or moral indifference falls more heavily upon the student himself than upon the world. For interest in the broadly human he substitutes, though often unconsciously, some form of class consciousness. His danger is not so much that of relapsing into mere individualism as of allowing himself to be segregated in a class. This habit once acquired, the pitfalls of a large part of the unhumanized world await him - the various pitfalls of class consciousness, in place of the broad vital consciousness of the human, the social class, the money class, the labor class, the party, the profession. His danger is really that of becoming a mere fragment, rather than an integral part of the life about him.

"Public-Mindedness," a volume of my public addresses on various aspects of good citizenship, reflects the spirit and tone of the familiar talks at Rollins Chapel on the sense of the human, as a part of the moral equipment of the college man in his contact with the world.

I refer to the religious sense last because it seemed to me that it was to be assumed. As the old-time "Preacher" put the matter with such convincing finality - Ecclesiastes III: 11 - "He hath made everything beautiful in its time: also He hath set eternity in their heart, yet so that man cannot find out the work that God hath done from the beginning even to the end." This implanting of "eternity" in the heart of man, it is to be assumed, has made the religious sense an abiding force in the midst alike of the distracting beauty of the world, and the bewildering mystery of the universe. There are unrealities in many of the conventional beliefs of men, but I know of nothing in them to compare with the absolute unreality of mere unbelief. But here again, as in the development 


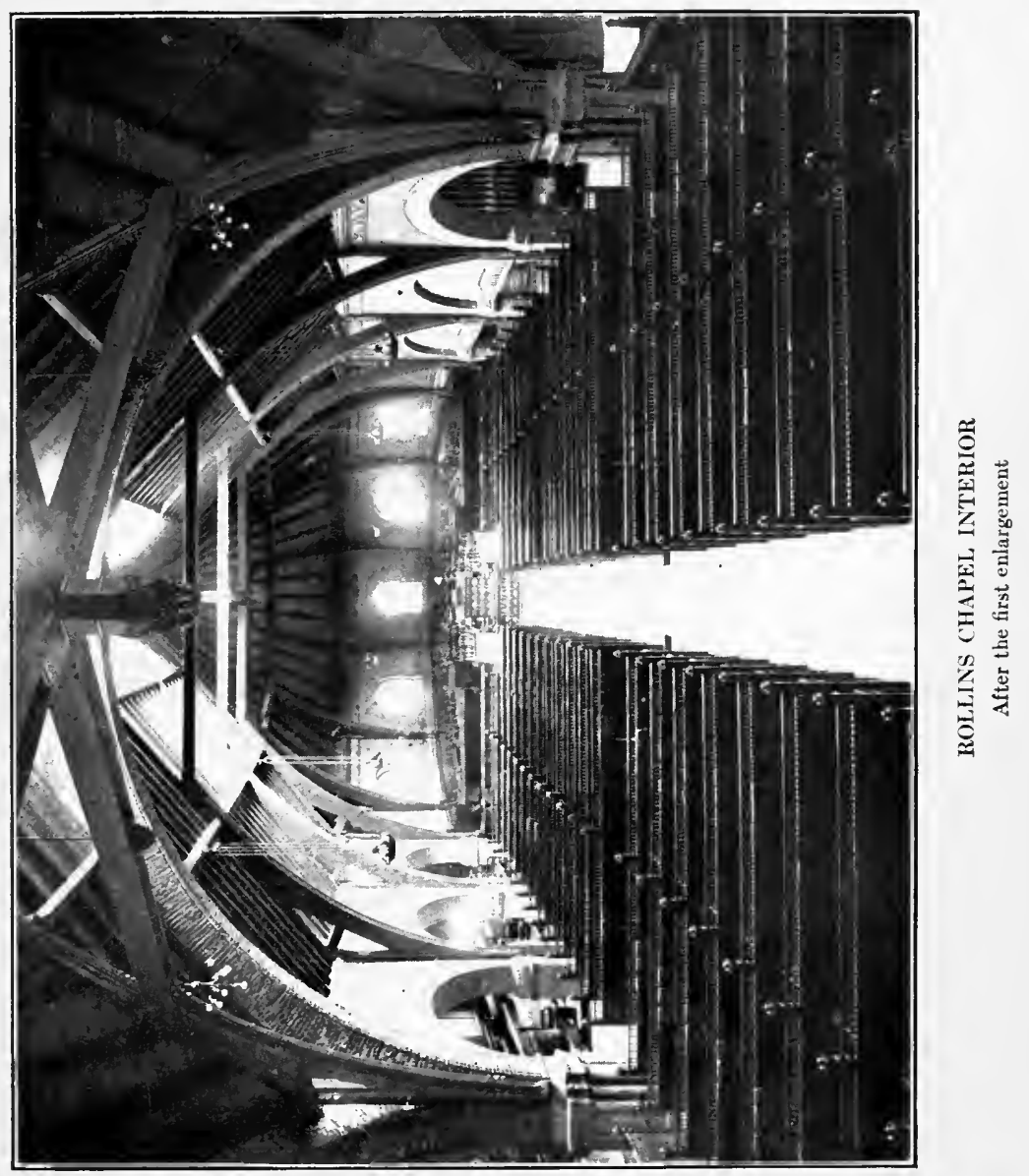


- 
of the sense of the personal and of the sense of the human, it became evident to me that the development of the religious sense must accord with the habit of mind induced by academic training, namely, the questioning habit. The academic approach to a subject, the attack if the subject be difficult, is through the question. The question persisted in becomes research, and the cumulative result to the questioner the scientific habit of mind. But one of the unconscious effects is often seen in a certain sag of the mind, the easy relapse into a merely questioning mood, in which subjects of high moment may be set aside for possible consideration without regard to their intrinsic importance. And this laissez-faire state of mind may be coupled with such pride of intellectual freedom as to create a well-nigh insufferable conceit. It was doubtless such an exhibition of conceit as called out the impatient reply of the Master of Balliol to the casual remark of a student who presented himself for matriculation, one of the conditions being the assent of the applicant to an article affirming the existence of God, "Well, I haven't made up my mind on that subject" - "I'll give you fifteen minutes to make it up." But I always felt that any like exhibition of ephemeral conceit was to be carefully distinguished from doubt. The doubting mind always seemed to me to be a part of the believing mind, and to be so classed. The genuinely doubting mind welcomes the interpretation of truth in place of fruitless argument and discussion.

The College Chapel, as I believe, should allow the spirit of the philosophical classroom, but it has its own atmosphere. It seeks not only the demonstration of truth, but the impression of truth. Religion has its times and seasons 
which may properly be utilized. I never hesitated to observe the seasons of Advent and Lent for direct religious impression. Academic religion has its limitations, but it is not straitened in itself, or in any use of rational means for the development of the religious sense. The college environment may not shut out that larger environment of the human world; much less may it shut out that far greater environment which corresponds to the "eternity" set in every human heart.

I hesitatc to go further. The remembrances of the fifteen years of contact with the mind of the College, through the Sunday Vespers in Rollins Chapel, are in many ways too personal even for the pages of an autobiography. The generations of college men as they came and went, filling the rows of the chapel benches, still pass before me in the orderly procession of the years. But the service itself as a medium of personal contact with the College, may be noted as an illustration of one method through which so desirable an end may be reached. More frequent use has been, and is still being made of the classroom. Other ways are yet more individual. Some men have the gifts of the "office" quite as marked in their influence as the gifts of the "chair." The chapel service came to me as my opportunity, and soon became recognized as such, for seeking to affect the college morale. I may therefore quote in this connection the opinion of two or three who have put on record their estimate of the meaning of the service. In a paper read by Professor Asakawa of Yale at the fifteenth reunion of his own class (1899) at Dartmouth, and printed in the "Dartmouth Alumni Magazine" of March, 1915, the writer enters into a most critical interpretation of this particular service rendered by "our teacher," as he applies 
to me the term of such honor to the Eastern mind. The whole paper interprets the intent and method of the service with an insight and understanding which humbled me as I read it. I was greatly pleased with this mark of Dr. Asakawa's fine discernment: "How many of us realized that while we were being stimulated by Dr. Tucker, he himself was drawing inspiration from his work for us? ... So there was give-and-take between him and us; no doubt he gave us more than we ever knew, and took from us more than we were able to take from him."

In a brief review of the period of my administration contributed to the College " Egis" of 1911, Professor Charles F. Richardson gave the following estimate of the relative value of this service as compared with the external results of the administration: "In my opinion his (President Tucker's) largest, most important and enduring achievement has been ... the effect of his personality and his teachings upon . . . the undergraduate body. This influence has been made manifest . . . most of all in his Sunday evening talks at Rollins Chapel. These have been virtually unique. ... Every Dartmouth alumnus of the past sixteen years will agree with me that whatever he has got from the classroom, societies, friendships, or the athletic field, nothing quite takes the place in his tenderest memories of college days, of Dr. Tucker's vesper talks Sunday after Sunday."

I cannot refrain from adding to these expressions of opinion from within the College, this interpretation by Professor Francis G. Peabody of the characteristics of the type of preaching disclosed in the volume of sermons based on the chapel service. I am indebted beyond all claims of personal friendship for such a recognition of the 
purpose of these sermons, by one who is the acknowledged master in the college pulpit of New England. Contrasting the different methods pursued by English and American college preachers in an article on "University Preaching" in the "Harvard Theological Review" for April, 1916, he passes on to the discussion of the possibility of combining the more intimate approach of the American preacher with the larger horizon of the English preacher:

This synthesis of vitality with wisdom, of personal appeal with philosophical insight, is not without distinguished illustration in the university preaching of the United States. "The Counsels to College Men," the sub-title of "Personal Power," by President Tucker of Dartmouth College, for example (one of several volumes of college sermons referred to), combine in a striking degree the intimate approach and the large horizon. In their primary concern for students as hearers they depart from the English tradition; but in their sweep of thought and large conclusions they are of the school of Newman and Mozley. "Let me speak to you of the satisfactions of life," begins one of these discourses, as though preacher and student stood together on the level of ordinary experience; but the same sermon ends on the heights of mature and prophetic vision: "The modern world will not long be the world which marked a sudden shift from mediævalism. The reaction is spent. Neither is it the world of raw force or of rank material power. The noise and smoke of its work, its sudden and unstable wealth, its pride and vain-glory, its impossible art, its commercialized morals, its crude, self-sufficient, unbelieving men - all these are fast going the way of their kind. These do not make up the world of tomorrow, the world in which your achievements are to be ranked and in which you are to be measured. You are in a world which will have ample room in it for the intellectual life, for rewarding action of every kind, for sincere and satisfying companionship, and for faith. Do not miss your place in it. Do not live out of date. Make your own generation. Take the better fortune of 
your own time." Again the same preacher begins, with persuasive simplicity, "I want to speak to you about Jesus' test of moral maturity"; but near its close he rises to the passage: "I count it a great moral obligation of all believing men to have faith in the working power of Christ's sayings. . . . Believe in men against appearances. Do not take men at their word when they talk below themselves. Use the true, never the false in human nature, and persist in doing this. So shall you gain access, every one of you in his own way, to the heart of humanity." Here is movement, lift, enlargement, surprise. Through the narrow door of personal experience the hearer is led into the great temple of a rational faith. Moral inspiration and intellectual precision meet, and from their fusion proceed light, heat, and power.

\section{V}

An Advanced Policy toward Non-Professional Graduates

College education in this country was from the very beginning set to some definite end outside and beyond itself. This end has been for the most part satisfied in the relation of the colleges to the professions. A liberal education has never been allowed to become the mere perquisite of a leisure class. We have accepted the English requirement that it must be "fit for a gentleman," but we have added the implication - a gentleman at work. With us the natural complement of a liberal education has been a professional life.

Dartmouth has always kept faith with the professions, and never more strictly than in support of the recent efforts for the advancement of professional standards. There have been times, it is true, of an unapprehended danger to the promotion of professional standards from the stirrings of the university idea. The position of Dartmouth, relatively remote from the centers, but central to 
a large and somewhat distinct territory, has frequently suggested the ambition to assume the functions of a university, which if realized would have added one more to the aggregation of minor professional schools. The presence of the medical school, existing almost from the first in various relations to the College, has been a local reminder of natural possibilities in this direction. Even so sane a mind as that of President Lord was at one time seriously infected with the university idea. In 1841, stimulated by the largest enrollment in the history of the College, placing it on a full numerical equality with any of the New England colleges, he urged upon the Trustees the restoration of the Chair of Divinity to active use, saying that "another step," referring to the possible provision for a law professorship, "will then place the College in the position of a university, to which Divine Providence has been so evidently leading it, and for which public opinion is in a great degree prepared." The unaccountable decline in the number of students which soon followed, though temporary, and the consequent decline in current income, put the project permanently out of thought during his administration. The "idea," however, survived in a plan to organize a "learned Society that should be nearly related to the College and serve to concentrate upon it the moral and intellectual resources of the Northern part of New England." This plan was consummated in the organization of the Northern Academy, which flourished for quite a number of years as a literary society, and later was resumed for a time as a scientific society, finally leaving as its memorial a creditable collection of literary and scientific works to be absorbed into the college library.

The university idea made a still stronger appeal to the 
vivid imagination of President Smith, and during his administration came much nearer to realization. It was his aim to concentrate the higher educational interests of the State at Hanover, and through his efforts the New Hampshire College of Agriculture and the Mechanic Arts was first located there. The Thayer School was established in his administration practically on the basis of a graduate school. There was the definite promise, according to public announcement, of three large bequests which had they become available in his time, would have materially aided in the working-out of his large plans. Their failure to "arrive" till it was too late for his uses, was a pathetic illustration of the saying as applied to successions in a college presidency - "one soweth and another reapeth." The subsequent removal of the Agricultural College to Durham, which took place just before the close of President Bartlett's administration, closed the door to further efforts in behalf of a university based on State needs or resources. The sympathies and activities of President Bartlett were altogether in favor of the development of the College as such. It was through his negotiation with the heirs of the estate of Chief Justice Joel Parker that the bequest left to the College for the establishment of a Law School was converted into the foundation of a professorship of Law and Political Science, and into a library fund for its uses. I recall, however, in the early part of my administration, a correspondence with one of our ablest legal graduates, Professor William C. Robinson of the Yale Law School, urging upon me the recovery of this fund to its first proposed use, with an appeal to the alumni and to the State to supplement the fund with an amount sufficient for the endowment of a School. He urged this on 
the ground largely of state advantage, declaring that New Hampshire was, with one exception, the only State in the Union without a law school. I replied that I failed to see the local necessity in view of the proximity of neighboring schools of recognized merit, and that $I$ could not advise the establishment of a law school in connection with Dartmouth which might fall below their standard. I argued that Dartmouth in this matter owed more to the profession than to the State.

In regard to the Medical School, so long and honorably identified with the College, it may be said that it was brought step by step into harmony with the progress of medical instruction - first in 1890, near the close of President Bartlett's administration, by making it a four years' course, then some years later during my administration, by requiring a college training or its equivalent for admission, and finally in President Nichols's administration, being unable to satisfy the full requirements of the American Medical Association in the matter of hospital service, by giving up the last two years, that the school might retain in the first two years its $A$ standing among the schools.

For the teaching profession, the College has not attempted to establish a Graduate School. Graduate study has been confined to a few departments which have had at times special facilities for carrying it on successfully.

In one way or other - in its earlier history by the force of circumstances and in later times by fixed purposeDartmouth had been preserved from becoming the danger to the professions which the small university, with its inferior facilities for reaching the higher professional standards, presents. In its numerical accounting with the 
professions, the account of Dartmouth represented very nearly the entire contribution of its graduates, until the responsibility of the College to its non-professional graduates became more urgent, if not more important.

When I recall the historic position of Dartmouth and its relation to the apparently conflicting demands of liberal and professional education, I am ready to accept in its behalf the congratulatory words of President Hadley of Yale on the occasion of the rebuilding of Dartmouth Hall: "Yale sends congratulations on the rebuilding of what has been in many senses a historical edifice in the American college world. For nearly three half-centuries Dartmouth has occupied an exceptional position: in the first generation as the northern outpost of American science and religion - like Durham of old;

Half house of God, half castle 'gainst the Scot;

in the next generation as the training place of one who, amid his many titles to fame and honor, has this special claim upon the remembrance of American scholars, that his efforts made our college charters eternally secure; and during later generations as an institution whose work for the cause of higher learning is thrown into salient relief by the fact that where so many institutions claim to do more than they actually accomplish, Dartmouth accomplishes more than she claims."

In the closing decade of the last century a marked change in the occupations of college graduates took place, or rather became almost startlingly apparent. A profession was no longer the exclusive goal. A new and large area of occupation had been entered upon under the general term of business. From the conventional point of view of 
the professions, the colleges were producing the "excess" graduate.

Comparing the statistics for the first two periods of fifty years each in the productive energy of Dartmouth with the thirty years immediately following, which brought the College to the close of the century, we have this result - from 1771-1820, graduates entering the professions of law, ministry, teaching, and medicine, ninety per cent; from 1821-1870, eighty-six per cent; from 1871 to 1900 , sixty-four per cent. The sharpness of the change is seen in the further drop in the succeeding decade, the opening decade of the present century, from sixty-four per cent to fifty-one per cent. The change here noted in respect to Dartmouth was representative of that which was taking place in all the Eastern colleges, the real significance of which was not to be estimated in numbers. The change meant that the colleges representing a liberal education were failing to make a responsible connection, through the lack of a proper intervening training, with the world of affairs. The interests in that newer world were quite comparable with those involved in professional life - banking, corporate administration, and all the problems incident to the economic development of the country. It was a confession of the inutility or narrowness of a liberal education, for the colleges to leave their graduates in a helpless attitude before their new responsibilities, or to commit them altogether to the fortune of their personal initiative. The introduction of so-called "business courses" into the undergraduate curriculum was evidently a superficial and confusing treatment of the difficulty.

It was in the attempt to offer some satisfactory solution of the problem confronting the colleges that the Amos 
Tuck School of Administration and Finance had its origin. In the specifications attending the gift of the Tuck fund, provision had been made for the possible uses, in part, of the income from the fund for "professorships which may be in the future established in the College proper or in post-graduate departments, should such be added at any time to the regular college course." As it had been determined to apply the income of the Tuck fund mainly to the Department of Economics and kindred departments, it was now proposed to carry over the instruction in these departments into advanced courses which should constitute the basis of a graduate school. I was authorized by the Trustees to put this proposed action before Mr. Tuck, to ascertain if it would accord with his understanding of the uses of the Fund. This I did in a letter under date of December 1, 1899, enclosing a memorandum outlining the aim and methods of the proposed school. In response I received the cablegram - "Letter received. Fully approve proposed action in all points"; and later by letter the following endorsement of the plan:

The establishment of the Amos Tuck School of Administration and Finance has my full approval. The statement which you make of its purpose and scope is clear and convincing. I believe that it is just in the line of modern educational requirements and I shall be glad to see your plan put into effect.

At a meeting of the Trustees, held June 19, 1900, it was voted, "that the Trustees establish The Amos Tuck School of Administration and Finance, on the following outlines, presented by the President ":

Under the terms of the Amos Tuck Endowment Fund, the gift by Mr. Edward Tuck, of the Class of 1862, of the sum of 
Three Hundred Thousand Dollars as a memorial to his father, the Hon. Amos Tuck of the Class of 1835, and a Trustee of the College from 1857 to 1866 , especial provision was made for the "establishment of additional professorships within the College proper or in graduate departments." In accordance with this provision of the endowment fund for additional instruction in undergraduate and graduate courses, and with the approval of the donor, the Trustees of Dartmouth College hereby create the Amos Tuck School of Administration and Finance.

First. This school is established in the interest of college graduates who desire to engage in affairs rather than enter the professions. It is the aim of the school to prepare men in those fundamental principles which determine the conduct of affairs, and to give specific instruction in the laws pertaining to property, in the management of trusts and investments, in the problems of taxation and currency, in the methods of corporate and municipal administration, and in subjects connected with the civil and consular service. The attempt will be made to follow the increasing number of college graduates who have in view administrative or financial careers, with a preparation equivalent in its purpose to that obtained in the professional or technical schools. The training of the school is not designed to take the place of an apprenticeship in any given business, but it is believed that the same amount of academic training is called for, under the enlarging demands of business, as for the professions or for the productive industries.

Second. The school is open to those who present a Bachelor's degree and in special cases to those who are able to pass an examination which will guarantee an equal fitness for the studies to be pursued. The courses which are now offered cover two years of graduate study. If a student is able to present courses taken as advanced electives in the undergraduate curriculum which are substantially the same as those offered in the first year, he will be given standing in the second year. Special students may be received for the pursuit of particular courses who will be given certificates for work actually accomplished, but who will not receive the full certification or degree of the school. 
Third. The courses of study pursued within the school shall be chiefly those which lie within the departments of Modern History, Economics, Sociology, Political Science and Law, together with the departments of modern languages. In all cases the work of the school shall represent advanced courses in these departments. In the first year the courses shall be largely theoretical; in the second year they shall represent the application of theory to particular forms of business so far as practicable.

Fourth. The work of the school shall be carried on by instructors in Dartmouth College within the departments above named, with the assistance of special instructors or lecturers on definite topics which may be prescribed. In so far as instructors in the academic department of the College take part in the instruction of the school it shall be without extra compensation. [This specification was later amended to provide in large degree for separate instructors in the school.]

Fifth. Tuition for the school shall be the same as for the college, but scholarships given for students in the College shall not be available for students in the school, except for those who may be enrolled during the first year both in the College and in the school.

The school having been organized and preparations made for instruction the following year, Mr. Tuck supplemented his original gift by the transfer of securities for the erection of a suitable building for the school. Under date of August 29, 1901, he wrote:

I am now sending you certificates for Five Hundred shares, preferred stock of the Great Northern Railway Company of Minnesota, registered in the name of "The Trustees of Dartmouth College," to be added to the "Amos Tuck Endowment Fund."

The purpose of this donation is to supply the necessary means for erecting, equipping and maintaining a building suited to the uses of the Tuck School of Administration and Finance, and incidentally for the accommodation of such other kindred departments of the College as the Trustees may deem wise and appropriate. 
To the correspondence of Mr. Tuck regarding the establishment of the school should be added his statement of the ethical purpose which should inspire alike instructors and graduates. This statement is inscribed on a tablet placed midway on the double stairway opposite the entrance to the building:

In the conduct of the school to which you have done my father's memory the honor of attaching his name, I trust that certain elementary but vital principles, on which he greatly dwelt in his advice to young men, whether entering upon a professional or business career, may not be lost sight of in the variety of technical subjects of which the regular curriculum is composed. Briefly, these principles or maxims are: absolute devotion to the career which one selects, and to the interests of one's superiors or employers; the desire and determination to do more rather than less than one's required duties; perfect accuracy and promptness in all undertakings, and absence from one's vocabulary of the word "forget"; never to vary a hair's breadth from the truth nor from the path of strictest honesty and honor, with perfect confidence in the wisdom of doing right as the surest means of achieving success. To the maxim that honesty is the best policy should be added another : that altruism is the highest and best form of egoism as a principle of conduct to be followed by those who strive for success and happiness in public or business relations as well as in those of private life.

In establishing the Tuck School as a school of advanced instruction, the College took a step in the exercise of the creative function of liberal education. Once before it had moved, though not so directly upon its own initiative, in the same direction. When General Sylvanus Thayer, a graduate of the class of 1807, known at West Point as the "Father of the Military Academy," sought for some definite way of advancing Civil Engineering to the grade of the professions, he turned to his Alma Mater for aid. 
What he wanted to secure was the breadth and stimulus of a liberal education in the furtherance of his purpose. At his request the College became the "trustee" of the fund which he had set apart for the endowment of a graduate school. The virtual control of the school was to rest with a Board of Overseers, first to be appointed by himself and then to be self-perpetuating, the President of the College to be president of the Board. This was in 1874 . The Trustees of the College assented to the arrangement, which proved to be highly advantageous to both parties. In 1908, the Trustees recognized the School as constituting "in fact and substance a post-graduate course or department of the College."

The success of the Thayer School in helping to carry out the aim of its founder was in mind when the thought of a school of like aims in the sphere of Finance began to take shape. There were, however, two causes which gave a certain immediacy to the establishment of the Tuck School - first the urgency of the situation, and second the willing response of Mr. Tuck to the proposal. These two causes were the justification, the ample justification, for the prompt exercise of what I have termed the creative function of liberal education.

But the broad educational reason for such an invasion of the business world as that carried out through the Tuck School, lay in the fact that the higher education was working very unequally in that unclassified region. The technical schools were at work for a definite purpose. Their training created a habit of mind of great value: but there was need of another habit of mind which might work with equal definiteness. If there were occupations of high grade which required the rigidly scientific habit, there were other 
occupations which required the habit of analysis, comparison, and coördination. This was the habit requisite to large success in the economic field. It was by distinction the habit sought to be produced by a liberal education. And a further demand of the economic field was for mind trained in the consideration of the human element in the practical world. Questions of labor were as much a part of the economic problem as questions of finance. Modern science had created the industrial world, it had become a matter of economic concern to humanize it.

I cannot put by this conception of the creative, informing, humanizing function of a liberal education without emphasizing the present need of the continuous exercise in some form of this function, by those who may be assumed to know its use. There is a habit of mind among the graduates of our colleges, which fosters too much the idea of the immunity of a liberal education from the distracting and disintegrating influences of modern thought and life. I know of but one way to break up this habit, namely, for the colleges to follow their graduates with the stimulus of the education of which they may be made more appreciative than they were in their undergraduate days; to go in and out among them with the liberating and liberalizing idea which they may never have really understood; to make them feel, it may be, through their own belated experiences the vital and far-reaching influence of the liberal education, if it be given the freedom of the modern world: With this view of present educational necessities, I read with great interest the recent announcement of President Hopkins of the founding of two ample lectureships for the special object of stimulating the intellectual life of the alumni, through the perpetuation 
of the original impulse which sent them to college, acting now in a vastly wider environment. I quote the announcement from the report in the "Dartmouth Alumni Magazine" of the exercises at the dinner following the Commencement of 1917:

I have the privilege of announcing another gift to the College from one of its most loyal alumni, in the establishment of two lectureships of major import, designed primarily for the alumni of Dartmouth College, and open to students of the College or friends who may wish to utilize the advantages of the scheme as proposed. This is made possible through the generosity of $\mathrm{Mr}$. Henry L. Moore, one of the trustees of the College, and a graduate of the class of ' 77 now celebrating its fortieth anniversary.

The lectureships will be known as "The Dartmouth Alumni Lectureships on the Guernsey Center Moore Foundation," and they are established in loving remembrance of Mr. Moore's son, a member of the class of 1904, whose sad death occurred early in his course.

This gift is an extension on Mr. Moore's part of the principle to which he committed himself more than ten years ago, in accordance with the advice of President Tucker, that great good could be done the College by the donating of such funds as Mr. Moore found himself able to give the College for the purpose of its cultural advantage. In accordance with this desire on the part of the donor, the frequent gifts to the College from him have been applied to the development of the work in Fine Arts. It is a logical and profitable extension of such an interest that now makes available for alumni and friends of the College a cultural opportunity to sit under leaders of the world's thought, who may be secured to speak on various themes with which the purposes of the College concern themselves. The tentative plan is something like this, - that the lectures shall be given annually by two men of the highest distinction in their respective fields. They will occur daily, five days in the week, for two weeks, - a total of ten lectures from each man. It is expected that this will be an opportunity eagerly seized upon by men as they come to 
understand in regard to it, and working to greater and greater advantage of the alumni of the College in eliminating the present anomalous condition, in which the College makes no attempt whatsoever to perpetuate its cultural influence on its graduates after the date upon which they receive their diplomas.

Some colleges, placed within large cities, do extension work in their own communities; and others, administered under state auspices, render large service to their state constituencies. Mr. Moore's plan, however, projects an extension work for the benefit of college graduates, and men whose interests lead them into these groups. The proposal is based on the argument that, if the College has conviction that its influence is worth seeking at the expense of four vital years in the formative period of a man's life, the College ought to offer some method of giving access to this influence to its graduates in their subsequent years. Moreover, the growing practice of retiring men from active work at ages from sixty-five to seventy, and the not infrequent tragedy of the man who has no resources for interesting himself outside the routine of which he has been relieved, make it seem that the College has no less an opportunity to be of service to its men in their old age than in their youth, if only it can establish the procedure by which it can periodically throughout their lives give them opportunity to replenish their intellectual reserves.

Mr. Moore's assurance to the trustees has been that he would be glad to make the income of $\$ 100,000$ available to the College for a period of years, for the support of this plan; and if the plan should prove to have the advantage that it is expected to have, that he would then transfer the principal to the College, thus insuring permanency to the project.

\section{VI}

Professional and Public Relations during the Presidency

The college presidency is an anomaly among the professions. In and of itself it has no professional standing. Whoever occupies it must furnish his own professional 
guarantees. The multiplicity of academic degrees with which the average college president is invested has in this respect no significance. Academic degrees are of three kinds - the earned degree which defines one professionally; the honorary degree bestowed presumably for professional excellence, most happily bestowed when it is a reward for excellence without the aid of academic training and the complimentary degree of which college presidents are made the unhappy recipients as the representatives of their respective colleges. The custom of the past one or two decades of making the inauguration of a college president the occasion for conferring degrees upon all within the reach of the particular academic fellowship, so far as time allows, has ceased to be significant or impressive. It is a custom which as "honored in the breach" confers honor upon the college that exercises a becoming self-restraint.

It is, of course, an infelicity that there is no authorized academic approach to a college presidency, not even through the faculty. Neither teaching nor research can give the requisite training for administration. There are indications of the growing recognition of the normal path to adninistrative responsibility through some form of direct administrative training. Examples of the tendency are to be seen in the recent election of Secretary Hopkins, though after a short period of executive service elsewhere, to the presidency of Dartmouth, and of Dean Sills to the presidency of Bowdoin. Doubtless in due time a college presidency will evolve or acquire its own professional standing. Meanwhile the distinguishing feature of a college presidency in the place allotted to it by courtesy among the professions is the ground it covers. No profession has the 
same variety of semi-public duties assigned to it or expected of it. The public expectation is not infrequently embarrassing as it finds expression in the neatly turned compliment. In introducing me, soon after my advent at Dartmouth, as a speaker at the dedication of the new state library building of New Hampshire, the presiding officer made use very graciously of the epigram of Macaulay on Sir William Temple. "I think," he said, "that I may adopt the words of the brilliant essayist and historian in introducing to you Dr. Tucker, President of Dartmouth - 'a man of the world among men of letters, and a man of letters among men of the world.'” However much I might have been disposed to disclaim the right to a place in the historic succession to this epigram, I could not deny its pertinence as expressing the public estimate of the supposed fitness for the position I had assumed.

When one's professional career is broken in upon midway, through a sudden change in work, it is inevitable that some unfinished tasks or unfulfilled engagements must be carried over into the new work. The sudden change from Andover to Dartmouth found me under certain obligations of which I could not at once divest myself. I have referred to the fact that I had been obliged to ask for a year's deferment of my engagement at the Lowell Institute. The deferred date was reached in the winter of my first year at Dartmouth. The engagement was for eight lectures at Huntington Hall on Monday and Thursday evenings of successive weeks. As I had been unable to make full preparation in advance, especially in the writing of the lectures, I found it necessary to absent myself from the college for a month, taking up my quarters at the Parker House, where I had become much at home, and devoting 


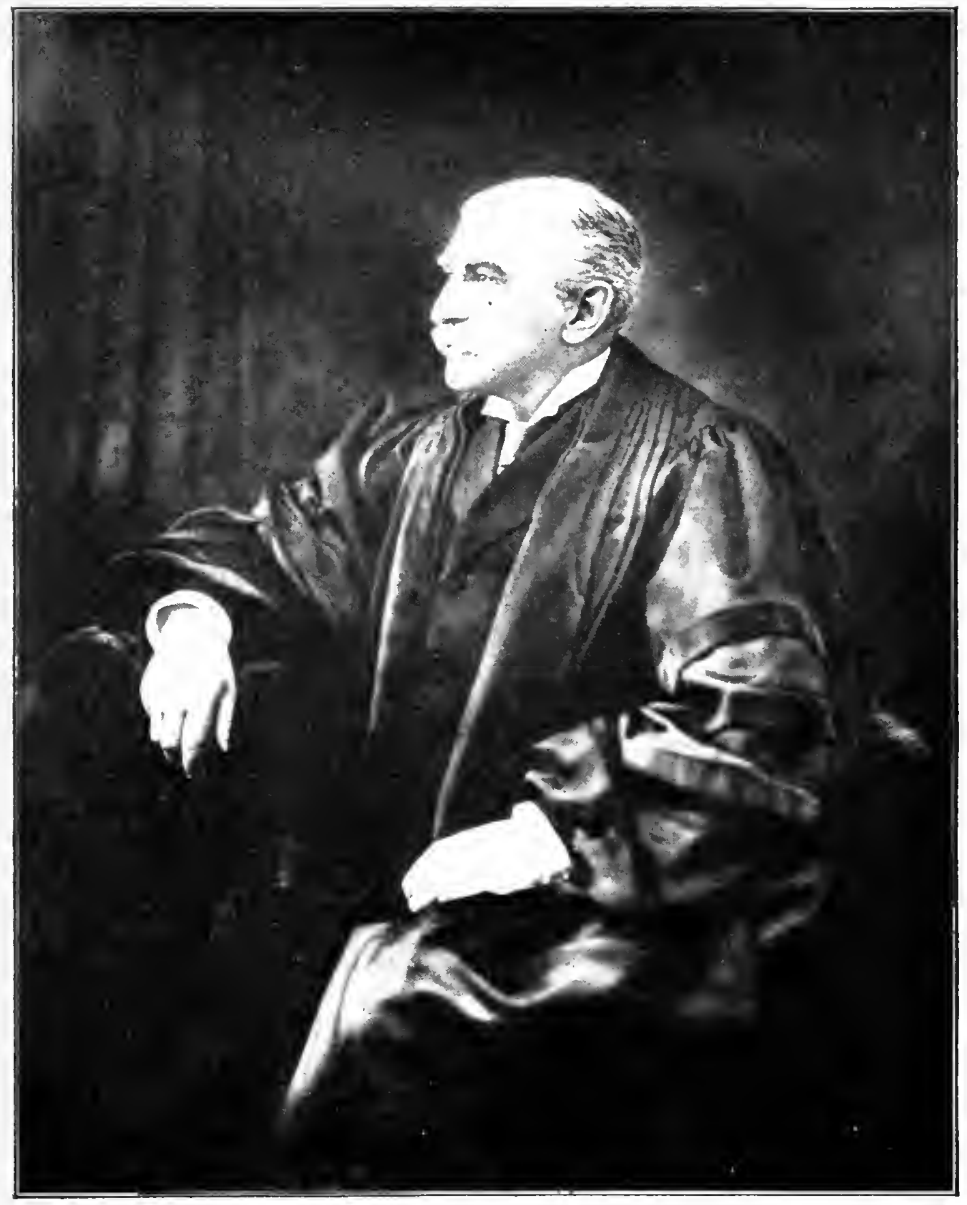

PRESIDENT TLCKER, 1899 

myself with little time for anything else to the continuous and strenuous work before me. I need hardly say that it was of absorbing interest. The subject which Mr. Lowell had chosen - "The Influence of Religion To-day" - I construed to mean the power of religion to make its influence felt at a time marked by the partial suspension of its authority. The lectures were fully reported in the daily papers. The Boston correspondent of the "Outlook," Julius H. Ward, on the staff of the "Herald," gave the following summary of the course, leading into a discussion of the treatment of the several topies:

The aim of President Tucker in these lectures has been not to discuss organized religion and ecclesiasticism, but to recognize the religious spirit wherever it exists, and to show by significant illustrations in what direction religious thought is moving and working in our own time. It has been notable, as these lectures have proceeded, how skillfully Dr. Tucker has unloaded theological baggage and got down to the real point of things. $\mathrm{He}$ escaped at once from the environment of formal religion by taking a certain point of view. This will be perhaps best seen by a summary of the titles of the lectures in succession. The first was on the direction of spiritual influence to-day; the second was on religion as it expresses itself through the "enthusiasm for humanity"; the third took up religion as the reformer of theology, passing beyond its organized forms; the fourth traced the development and bearings of agnosticism; the fifth traced the growth and the bearings of secularism; the sixth took up the present significance of religious toleration; the seventh treated the reciprocity of religions, and showed the mutual influence of the diverse minds and races now coming into religious contact; and the eighth treated of religious unity as waiting the coming of the full conception of the kingdom of God.

The preparation and delivery of these lectures, though as I have said a very strenuous piece of work, was to me 
an intellectual stimulus and refreshment, and not without a certain advantage to the College, in relating it more directly as an institution to the intellectual life of Boston. As the "Advertiser" remarked - "Dartmouth has long been prominent in Boston through her graduates; now for the first time it is beginning to be felt through the distinct personal contact of her president" - a remark, however, not strictly true, if intended to include the college Faculty. Professor Samuel Gilman Brown gave a course at the Lowell Institute during my college course on "English Parliamentary Orators," which he repeated, according to my vivid recollection, in the old College Church.

For a time after removing to Hanover I must have continued to preach, as circumstances in the College allowed, as I find by the following letter from Dr. Cabot, which gives some indication of the difficulties $I$ experienced in giving over many of the personal associations I had formed in the frequent supply of pulpits in Boston and vicinity.

\section{DeAR Sir,}

Massachusetts General Hospital April 17, 1894

I heard your sermons of last Sunday, and feel that I ought to write to you about them.

I have heard a great many sermons in the last ten years and have inevitably listened to them in the light of my scientific and philosophic study. Although I have profited by many of them, the larger portion have seemed to lose something of the weight they ought to have for the lack either of certainty, or of the grounds for certainty in the speaker's mind. Those who trusted their truth, did so, it seemed to me, too of ten on insufficient evidence; while those who had sifted the evidence more conscientiously, had not attained to such fulness of belief as could establish confidence in their hearers. 
Therefore it marks an epoch in my life to come in contact with a man who is as sure of his truth as you are, and upon such good grounds. There seems to me to be a great hunger among the people I see for just what you give, - a rational Christianity. We have so much rationalism that is unchristian, and so much Christianity that is not rational in Boston that many have come to the belief that a rational Christianity is impossible.

I suppose any man cares to know as far as he can that his work is effective. It seems to me that such sermons as you preached last Sunday are more important and more helpful to the present generation in the present phase of their development than any single influence I know of. That they should impress me - an average listener - so deeply, and that I should hear of them from other physicians and from most of the educated men to whom I have spoken of them, as producing a similar effect on them, seems to me a fact in which you might justly take satisfaction. $\mathrm{My}$ only regret is that you are not established where Boston can hear more of you.

I thank you with all my heart for your sermons and for all that they stand as results of.

Yours sincerely

Richard C. Cabot, M.D.

I greatly value this letter as showing the stimulus to a preacher in the spirit and attitude of many of the most highly trained and discriminating minds towards religious truth.

My personal connection with certain local interests in Boston was maintained for a considerable time through my continued identification with the Andover (South End) House; and until now my knowledge of those interests and affairs which $I$ have had most in mind, has been maintained through my uninterrupted intimacy with $\mathrm{Mr}$. Robert A. Woods, the Head of the House.

Another deferred engagement was that of service on the 
Harvard Board of Preachers. This service was quite different from occasional preaching at Appleton Chapel, calling for three weeks of daily attendance at the University twice a year, and including the Sundays at Appleton Chapel, the daily conduct of morning chapel with a brief address, daily office hours during the forenoon at Wadsworth House, following the service in the Chapel. Through the considerate kindness of Professor Peabody, I was relieved of half of the engagement; and the engagement itself had more than a compensation in the friendly interchange of services which brought Professor Peabody to the Dartmouth Board of Preachers, and Professor George H. Palmer to a lectureship for two successive years in the Department of Philosophy.

Still another deferred engagement $I$ have taken note of in another connection, the delivery in 1898 of the Yale Lectures on Preaching, on the Lyman Beecher Foundation. The subject of this course of lectures was "The Making and the Unmaking of the Preacher." The lectures were published under the above title by Houghton Mifflin Company.

I make reference because of the connection to yet another course of lectures, not at all a deferred engagement, but given in response to an invitation from the Directors and Faculty of Union Seminary, on the Morse Foundation, which found me in a willing mood on account of a fit subject that had for some time occupied my mind in its freer hours, namely, the distinctive problem of modern Christianity. I think that my interest in this particular problem started from a remark by Mr. Huxley to the effect that the world in which he lived for the most part was neither Christian nor unchristian, but extra- 
Christian. What was, or should be the definite relation of Christianity to this extra-Christian world? This was an intensely practical question, for this extra-Christian world of Mr. Huxley's evidently corresponded quite closely to what we had begun to know as the modern world, a creative world, vital with forces which are in themselves the sources of human progress. But Christianity is a religion, the only religion, which undertakes to deal with man as the subject of progress whatever may be the sources of progress. What then shall be its relation to the modern world whose progress is due so largely to causes outside the action of forces peculiar to Christianity? The lectures on this subject were given in New York in 1902, under the broad title of "Modern Christianity" - by no means so commonplace or broad a subject then as now. I had hoped, as indeed it was the understanding, that I should make a book out of them, reducing the subject-matter more strictly to a critical study of the problem involved in the present environment of Christianity, so different in its effect from any which had preceded. But the book was never written, owing to the increasing pressure of college duties. I was able, however, through the courtesy of Union Seminary, to repeat the lectures, in modified form, on the Earle Foundation at the Pacific Theological Seminary, Berkeley, California. This was in 1906. I recall with peculiar pleasure the visit to Berkeley - the outward trip by the Santa Fé, though we missed for lack of time the Grand Canyon, the provision made for Mrs. Tucker and myself at Cloyne Court, the association with the University, and especially my intercourse with the faculty of the Seminary. One could not ask for a season of professional companionship characterized by a truer spirit of hospitality, by more sincerity 
and freedom of thought, or by a larger vision of Christian faith. The return trip was in marked contrast with the outward bound. We left San Francisco for Southern California just in advance of the earthquake, having reached Santa Barbara when the news of it came to us. It became at once the great question for travelers how to secure transportation to the East. We made our exit, or as it seemed, our escape, by the new route then first opened (and soon after discontinued for a time) from Los Angeles through Salt Lake City. We had intended to return by the same route by which we came out, to recover the side trip to the Grand Canyon which we had missed, but for this we were in no mood had the way been open to us. There is no experience so depressing to a stranger as the sense that he is not only absolutely useless, but altogether in the way anywhere within the environment of a great local calamity.

An event of civic as well as of religious import, in which I took part, was the celebration in $\mathbf{1 8 9 7}$ of the fiftieth anniversary of the founding of Plymouth Church, and the beginning of the work of Henry Ward Beecher in Brooklyn. The celebration was distributed over several days with addresses by Dr. Lyman Abbott, Dr. Bradford of Montclair, New Jersey, and Rev. Dr. Charles A. Berry of England. The speakers of the closing evening were Dr. Gordon of Boston, Washington Gladden, and myself. These various addresses were published in book form under the title, "The New Puritanism." An interesting feature of the volume was the introduction by Rossiter IV. Raymond, setting forth the origin of the church and the circumstances attending the call of Mr. Beecher.

The semi-public duties of a college president begin in his 
response to one or more of the many causes represented in public education. Some of these interested me, others did not; and those which did not interest me personally I found it difficult to interest myself in professionally. This had been my weakness in my former profession. I had little liking for the ecclesiastical and purely denominational side of the ministry, though I fully recognized their religious significance. Necessary attendance at councils, conventions, and annual meetings was always a severe duty, seldom if ever an inspiration. The same feeling persisted in the transfer to the professional duties of an educator. The technical and conventional did not attract me. I took little interest in the science or art of pedagogy, though I saw the reason and necessity for such interest on the part of somebody in the profession. The matters which did interest me, most of them greatly, had to do with the educational values of the new subjectmatter finding its way into the schools of every grade, the new constituency of the colleges coming out of the public schools, the function of the State in education, - these and like matters. I find upon reference to my notebooks or to published addresses, the following subjects of discussion - "The Rights of the Period of Education," a plea not only for the requisite allowance of time for the schools but also for freedom to create a spirit, a sentiment, an atmosphere of their own; "Arrested Education - How Recovered"; "The High School the School of the Community"; "The Educational Function of the Public Library"; "What has Patriotism the Right to demand of Education," an address before the Union League Club of Chicago on Washington's Birthday, 1906; "Modern Education capable of Idealism," an ad- 
dress at President King's Inauguration at Oberlin; "The Study of Contemporary Greatness," an address before the officers and cadets of the Naval Academy at Annapolis. This last address had for its object the endeavor to aid men entering the service of the country, in forming their estimates of men in public life with whom they were to be concerned. The tests upon which I insisted as the constants of greatness always to be demanded, though not always to be expected in equal proportion in every really great man, were originality, authority, and beneficence. There are no equivalents for these qualities. Without these the claim to greatness is unreal if not untrue.

Much of the time of my annual visit among the alumni, extending often for a month, was occupied in engagements at the schools or at meetings of teachers. Some of the schools of Cleveland, Chicago, Minneapolis, Omaha, Denver, St. Louis, became as well known to me as the schools of New England. The informality of address which these visits allowed was far more quickening to me, and I think quite as useful to the schools as the more formal addresses. It allowed and meant the adaptation of subject to time and place; sometimes it meant the introduction of a challenging subject, which for its own nature might win a hearing. As I recall the visitation of so many public schools attending my alumni trips, I am reminded of my indebtedness to Mr. H. H. Hilton, of Chicago, toward the close of my official relation to the College a trustee, whose wide acquaintance with the schools and schoolmen of the Middle West enabled me to gain an increasing understanding of the local situation.

Naturally the most intimate of the public relations into which I came as the President of Dartmouth was with the 
State of New Hampshire. State and College had passed through singular vicissitudes in their relation to one another. The royal charter which gave to the College its right and privileges in the Province of New Hampshire could not determine its future political environment. The relations between Governor John Wentworth and President Wheelock were most intimate, but they were personal or official, in no sense political. Each was concerned for the interests entrusted to him and in the furtherance of their respective interests they acted in hearty and complete accord. With the outbreak of the Revolution and the change from the provincial to the colonial government, the College instantly and vehemently threw in its lot with the cause of liberty. It was a costly step, but taken without fear or hesitation. The action of the College was not, it could not have been, more patriotic than that of the State; but by the force of circumstances, that is, according to the political views of its constituency, it was more democratic than the State. The migration from Connecticut, which preceded and followed Dr. Wheelock and his School up the River, was imbued with the politieal creed of Hooker, the founder of the Connecticut Colony, of which the prime article was the integrity of the town as the elementary political unit. It was the basis of political representation. The colonial state, with its seat of government at Exeter or in some one of the centers of population in the eastern or southern parts, based its authority on numerical representation, ignoring the right of representation by towns. Instantly the towns along the Connecticut were in revolt, and looked to the college town of Hanover for leadership. The college community was not loath to assume it, and for six years carried on the contest, now by 
seeking to organize the State of New Connecticut out of the towns on either side of the river (the New Hampshire Grant claiming to include all territory to the border of New York), and now by joining with the settlers on the Grant between the river and New York in their effort to organize the State of Vermont. The latter project proceeded so far, that at one time the College put itself under the protection of the newly organized State prior to its admission to the Union. Until very recently, there was a small brick church standing in the town of Norwich at the head of the northern end of the main street, in which the legislature of the State of Vermont held its session in 1785, at which time it voted a tract of land to be incorporated into the township of Wheelock, "one moiety of the said premises" to be used for the benefit of Moor's Charity School under President Wheelock or his successors, and the other for the use of Dartmouth College under the control of the trustees or their successors.

It was in every way to the advantage of the College that the attempt to organize the State of New Connecticut out of the towns on the east and west banks of the river failed. The College would have been greatly circumscribed by the success of the attempt, and a political character would have been given to its reputation to the detriment of its academic standing. It was better politically that the States of New Hampshire and Vermont should have their present alignment. The struggle, however, left its impress upon each State - upon Vermont in its system of representation based upon the town as the unit, and upon New Hampshire by making the town the irreducible unit, at the price of maintaining the largest legislative body in the country. 
The story of this academic experiment in statecraft is one of the most interesting, and in many ways instructive, episodes in the political history of New England. Strictly speaking, it was no more academic than legal, or in general political. The recognized leaders - Judge Woodward and Judge Payne, Colonel Olcott and Joseph Marsh - were all men of affairs, as were their associates in the towns up and down the river. President Wheelock denied active participation in the movement, but there is little doubt about his influence, and his son John, then in the twenties, was accorded a place among the practical workers. The revolt was the assertion of the Connecticut political idea by men bred in that political school. Nevertheless, it was perhaps fittingly characterized as the college party, as having its center at Hanover, the college precinct, transformed for the time into the township of Dresden, in the expectation of becoming the capital of the new State, while the various publications in support of the movement emanated from that center. In any event, the popular verdict during the struggle and after traced its origin and development to the agency of the College. The practical politicians were very outspoken in this charge. Ethan Allen, of the "Bennington" or Western Vermont party, writing to the representatives of the "Exeter" or Eastern New Hampshire party with whom he had joined hands, characterized the college party as "a Petulent, Pettefoging, Scribbling sort of Gentry that will keep any government in hot water till they are thoroughly brought under by the exertions of authority." The answer of the Exeter party, in control of the convention to form a new constitution for the State of New Hampshire, was the insertion of the clause that "no president, professor, or instructor in 
any college should have a seat in either House of the Legislature or in the Council." This clause remained in force for ten years. Meanwhile and for some time longer, it represented the official and popular political feeling toward the College. It was twenty years after the retirement of Governor Wentworth (1775) before his seat as Trustee ex-officio on the Board of Trustees was occupied by any Governor, or as then styled, President of the State. In 1795 Governor John Taylor Gilman of Exeter took his seat, when, says Chase in his History of the College, "the full restoration of official relations of the State to the College were emphasized by the meeting in Hanover of the Legislature and the inauguration of Governor Gilman in the College Chapel."

This happier state of affairs continued nearly twenty years, till the opening of the great controversy over the charter of the College, which culminated in the appeal to the Supreme Court of the United States. The decision in the case was rendered in 1819, fifty years after the founding of the College and its location within the Province of New Hampshire. These fifty years, as has been seen, were to a far larger degree years of contention than of coöperation or even of agreement. The marvel is that after such an experience in the formative stage of their existence, State and College should have accepted the final result so unreservedly, and continued their relation on the basis of comity and respect. When I came to the presidency of the College in 1893, this relation had been unbroken for three quarters of a century. If there was at the time lack of enthusiasm for the College on the part of the State, it was due more than all else to a lack of enthusiasm of the State for itself. The decade of the eighties was a somewhat de- 
pressed period in respect to state pride and enthusiasm. The decade of the war had shown a retrograde movement in population, and although there had been a recovery, the rate of growth had not reached the normal standard of the country at large. It was the period when public attention was called to the decline of rural New England. An abandoned farm in the remote regions accessible to summer tourists, was much more sensitively in evidence than the newly constructed mills that lined the highways of travel. The readjustment in the industries of the State had not gone far enough to reassure the people at large. And to add to the confusion, the politics of the State had been demoralized and embittered by a protracted railroad war. Returning to the State at this juncture, I felt that whatever influence I might have from my position should be exercised for the advancement of the State as well as for the College. I declared publicly that "if I had not believed in the future of New Hampshire, I should not have accepted the presidency of Dartmouth." The first address which I gave on a state occasion, that of the dedication of the State Library Building (January 8, 1895), was on the "Renewal of Civic Pride in the Commonwealth" - a revival as essential as that which had followed the restoration of the nation, or that which was beginning to be manifest in the change of public feeling toward the municipality. An occasion which called for more thorough and comprehensive investigation into the actual condition of the State was afforded by an invitation to address an association made up of members of the present and past legislatures, June 30,1896 . The subject of the address was "New Hampshire during the Period of Industrial Reconstruction." My previous economic studies had given me a degree of 
preparation for the treatment of this subject, and I found myself greatly interested in the application of economic principles to the problems which it involved. The result was a hearty and appreciative response not only from those to whom the address was especially directed, but from many who read it as it was widely circulated through the State. A most cheering word came to me directly from Attorney-General A. E. Pillsbury of Massachusetts (a son of New Hampshire): "I doubt if even you appreciate what you have done for the State of New Hampshire and for Dartmouth College. Your address is the utterance of this generation concerning the State." At the request of Mr. Pillsbury, the address was repeated in substance before the Sons of New Hampshire in Boston.

The somewhat unusual occasions about this time for the interchange of courtesies between College and State were helpful to the maintenance of the quickened relations between them - on the part of the College, occasions like the Webster Centennial, and the Banquet to the Earl of Dartmouth following the Laying of the Corner Stone of the New Dartmouth Hall, and on the part of the State, occasions like the Presentation of Memorial Tablets by the State to the U.S.S. Kearsarge and the U.S.S. Alabama at Portsmouth, September 18, 1900. This particular occasion was so full of general as well as local interest that I refer to it in considerable detail. At its session in 1899, the Legislature of New Hampshire passed the following resolution relative to the new battleship to be known as the Kearsarge: "Whereas one of the nation's new battleships under construction by the Government, and now nearing completion, has received the name Kearsarge, Resolved, that in behalf of the people of New Hampshire, the Gov- 
ernor be asked to appoint a committee of citizens of the State to procure and present for the use of the Kearsarge a worthy testimonial, which shall bear with it the affectionate love of the people of New Hampshire for this noble ship which, because of the name it bears, must become of all the battleships New Hampshire's special pride."

The Committee appointed by the Governor to carry out the object specified in the resolution added of its own motion the recognition of the battleship Alabama, then nearly completed, as the ship always to be associated with the Kearsarge in the retrospect of the war:

It was a foregone conclusion that the Kearsarge should be honored by a gift which should worthily reflect New Hampshire pride and New Hampshire sentiment. The Commission could have stopped here, and procured merely a worthy gift for New Hampshire's battleship. But it felt that if only this were done New Hampshire would have lost a unique opportunity to perform a graceful act, an act which should have a national as well as a local significance. The Commission therefore asks the people of New Hampshire to make a presentation to the Kearsarge and to the Alabama. When the two great battleships, Kearsarge and Alabama, are about to enter the service of a united nation, can New Hampshire do a more worthy act than add to the glory which surrounds the name Kearsarge by making it a pledge between New Hampshire and Alabama that they and these two noble ships are united for the defense and welfare of a common country? The proposed gift to the Kearsarge will be a large bronze bas-relief, to be placed on the forward turret between the two 13-inch guns. The gift for the Alabama will probably be a large design in bronze appropriately inscribed, to be placed on one of the turrets. Dr. Tucker of Dartmouth College has been asked by his colleagues on the Commission to prepare the inscription.

In accordance with the above request the following inscription was prepared for the U.S.S. Kearsarge. It was 
placed upon a large bronze bas-relief below the two figures with clasped hands, representing the reunited North and South.

From the State of New Hampshire to the U.S.S. Kearsarge

To Maintain Justice Honor Freedom In the Service of a Reunited People

The Memorial to the U.S.S. Alabama took the form of a large bronze tablet carrying the following inscription:

The State of New Hampshire to the U.S.S. Alabama

This Tablet, Companion to that on the U.S.S. Kearsarge, Placed Here by Courtesy of the State of Alabama Perpetuates in

Enduring Peace Names Once Joined in Historic Combat

At the banquet which closed the day of public presentation, an incident of peculiar significance was introduced. Addresses had been made by the presiding officer, General Streeter, by Governors Rollins of New Hampshire and Johnston of Alabama, by Secretary Long of the Navy, by Secretary Gage of the Treasury, and by Admiral Farquhar, Commanding Officer of the North Atlantic Squadron, when Governor Rollins arose and presented to Governor Johnston two battle-flags once borne by Alabama regiments, but since the war in possession of the State of New Hampshire. This unexpected incident greatly stirred the guests at the banquet. It had been arranged that as President of Dartmouth I should make the concluding speech of the evening, in response to the toast - "The United States." The hour was so late when the incident occurred 
that the reporters had left, and no report of the speeches attending it was given in the daily papers. I give the speech as it was written out later from brief notes, at the special request of Governor Rollins:

Mr. Toastmaster, Governor Rollins and Governor Johnston -

The heart of the nation has been waiting for such an act as that which we have just witnessed, embodying as it does so completely the spirit of this memorable day. North and South alike have been ready to break through the restraints and reserves which naturally follow upon a civil war, and to reassert that feeling which is deeper than the feelings engendered by strife. The time has now come, we cannot be mistaken in believing, to break the silence of these past years, generous and healing though it has been - but not by words. Words cannot restore what deeds have taken away. It is the office of the fit and sincere act to bring back the old friendship. I count it the honorable and timely distinction of the states of New Hampshire and Alabama, a distinction which will certainly have its place in history, that they are able to lead the way in this really significant interchange of sentiment. Other states have been more conspicuously related to one another through their earlier past, as notably Massachusetts and Virginia. But the fortune of the recent war, shall I not say the comradeship of one of its greatest events, has given us our opportunity, and we have dared to take it. We have dared to call up the most thrilling, perhaps the most separating incident of the war; we have dared to bring together names which had thrust men farthest apart; we have dared to evoke the memory of a fight fierce and bitter unto death; and having done this what remains to be ignored, or evaded, or held back? The restoration of these flags is not a charity, it is not even a courtesy. These flags go back to you, men of Alabama, by the logic of the situation, and with them go our hearts.

I am asked to speak a brief closing word, after this act, to the toast - "The United States" - the most significant name among the nations, for it is a name which embodies a principle 
and a history, a name which has thus far been justified and maintained only through perpetual sacrifice. The sentiment of unity, I do not say the principle but the sentiment of unity, is the soul of our national life. We cannot exist as a nation without a passion for unity, second only if at all, to the passion for liberty. No nation of modern times has had an inner life like our own. Few nations have had any inner life compared with the outer life of conquest and empire. But from the very beginning the thought of the people of this country has been turned inward, and the point of solicitude, concession, and at last struggle, has been unity. At first it was unity simply as a means to an end, the end being freedom as expressed in independence, but sometimes it seemed as hard to ensure the means as to reach the end. The struggle leading up to the Revolution, and through it, was the struggle for unity quite as much as for liberty. I marvel more and more at the enduring patience, the constant forbearance, the unfailing sacrifices which wrought their sure result in our national independence. Liberty was won we say at Bunker Hill, at Trenton, at Yorktown: yes, but more clearly in the silent determination of consenting hearts, in the generous concessions of statesmen and soldiers, in the mutual support of the colonies, in the unbroken will of a people set on freedom. Liberty was won when Washington stood under the Cambridge Elm and without dissent took command of the meagre but united band of patriots from North and South. Victory rested in that calm, steadfast, compelling nature. For seven years it waited, but it was as sure as was his life, the central and commanding figure among men who knew no fear, who would not yield to dissensions, who would be one to the end.

And yet when the immediate end came, and the thirteen struggling colonies became the United States of America, there began to be felt at once that great concern as to how the Union might be saved. It was not an unwarranted concern. It affected every interest of the nation. There was not a debate in Congress, however remote the subject might be - the tariff, acquisition of territory, education - which was not sensitive to the danger which threatened the Union. Before a generation had passed 
the situation became tense. Then concession followed concession; compromise followed compromise. The effort to preserve the Union became pathetic. As the years went on, pathos deepened into tragedy. Public careers, the careers of many of our greatest statesmen, were sacrificed. Personal friendships were sundered. Gradually we became to outward appearance thoroughly sectionalized. At last the national tragedy came upon us. A generation went down into suffering and sorrow. To what end? For freedom? Yes, again for freedom, and in many ways through a nobler and more unselfish struggle than the first. I think that none of us would deny that the Civil War marvelously enlarged the idea of liberty, and refined its quality. But back in all of our hearts was the conviction that the nation must live. We could not believe that it was in the plan of God, we would not believe that it was really in the heart of man, that the nation should die, that the nation should cease to be the United States. The ineradicable, the indestructible passion for unity was in all whether we fought for it or against it.

And now that the struggle to gain the Union and to save it is over, who does not rejoice in the established integrity of the nation? Who does not feel the new sense of power, the new sense of security, the new sense of freedom? "We the people" are more than ever "we the States." We are no longer afraid to claim or to admit our mutual rights. Every State born out of the original compact, every State created out of acquired territory, every State now in the making, knows that it has the assurance of its safety and the promise of its greatness in the fact that it is an integral part of the United States. We may not minimize the perils which beset the future of the nation. No nation can guarantee its own future. But of the vital forces which are to conserve our national life we have put the two greatest to the proof. We have the right to believe that these will abide in their saving strength. When the prospect was far otherwise than it is to-day, when the perils to the Union were more evident than its safety, one man among us, native to these hills, who walked the streets of the city where we are met, uttered in the national Congress the memorable word of hope. Surely we cannot doubt the perpetuity of a 
nation which we have seen founded and refounded in "liberty and union." We of all men can least deny ourselves the hope that "liberty and union," which are ours by the rights of inheritance and by the rights of sacrifice, will abide with us according to the prophetic vision, "one and inseparable."

Of a very different character was the call which came later to join with certain other citizens in a strenuous endeavor to relieve the State from a humiliating condition, in which it had been placed unwittingly through an unconsidered action of the Legislature of 1905-06. In the closing days of its session a bill was introduced and rapidly passed by both houses chartering the New England Breedcrs' Club, for the avowed purpose " of raising, importing, and improving the breed of horses and other domestic animals in the State of New Hampshire." This action was taken on March 10, 1905. It was some months before the deception practiced in the introduction and putting through of the bill granting the charter was brought out, and then more in the way of suspicion and questioning than of proven imposition. It seemed impossible that a great gambling institution could have been set up in the State under the simple guise of a club chartered to improve the stock farms of New Hampshire, that reputable men should have lent their influence in its favor as a benefit to the State, and that the Legislature should have opened the doors of the State to its entrance, if it was not what it purported to be. This deception was supported by the almost superfluous clause of the bill providing against gambling or betting on the races, which were to be a part of the process of improving the breed of horses. The immediate success of the manipulators of the movement both without and within the State was a tribute to their evil skill in such matters. 
The Reverend Thomas Chalmers of Manchester was the first man to call public attention to the public danger. In an address before a religious convention held at Concord on the 26th of October he exposed the scheme, as it appeared to him, of foisting a great gambling concern in perpetuity upon the State, and asked that a committee be appointed for further investigation. The Convention responded promptly to his appeal, by nominating a committee entrusted with the business of appointing in its name a committee of representative citizens to carry out the will of the Convention. This Committee was secured, and was known as "The Committee of Twelve" appointed "to investigate the facts relating to the organization, methods and purposes of the so-called New England Breeders' Club," with the further instruction "to take such measures to arouse the moral forces of the State as the facts shall warrant." This Committee when secured organized by choosing Dr. Chalmers as Chairman, and proceeding at once to its business. There were two difficulties to be overcome before it could act freely and effectively. One was the danger of becoming complicated with external reform organizations desirous of exploiting in a general way the New Hampshire situation. To those who knew the independent spirit of the State, as later reformers from without or not sufficiently in the State had occasion to test it, it appeared necessary that the attempted reform should be made a state affair; that it should be made apparent that the State was capable of dealing in its own way with impostors when once discovered. The other difficulty was for the Committee to limit itself strictly to its instructions. It was an inviting field of inquiry to enter upon, lying at its very doors - How did the New England 
Breeders' Club get its charter; who was to blame; what were the methods employed? - but that was not the business of this Committee. With some reluctance on the part of a few of the Committee, but by an admirable selfrestraint on the part of those who would have liked to enter into the investigation suggested, the whole Committee gave itself up to the one object of making perfectly clear to the public just what the New England Breeders' Club was, and upon the basis of ascertained facts to take such measures as might lead as quickly as possible to ridding the State of the danger of its presence. A sub-committee was appointed to raise an investigating fund, and a subcommittee consisting of Edward C. Niles, Esq. of Concord, and myself, to carry out the investigation and to present the case when prepared to the Governor and Council. The report of this sub-committee, made in behalf of the Committee at large, took up in careful detail the proofs of the deception involved in the charter of the New England Breeders' Club, by showing the precise results of the Percy-Gray Bill in New York, of which the bill authorizing the Breeders' Club was practically a duplicate, especially as seen in the utterly untrustworthy character of the clauses forbidding betting and gambling, and by adducing carefully collated testimony, to show the actual working of race-tracks in various States run by the Association behind the Breeders' Club. It then discussed the question of the sufficiency of the laws of New Hampshire on betting and gambling to deal with the Club if it were allowed to operate in the State. The report closed with the direct petition to the Governor and Council:

Lnder the circumstances, as the only means of clearing up the situation, we respectfully ask that you exercise your constitu- 
tional right of requesting the Supreme Court of this State to submit to you their opinion upon the important points of law in question, particularly as to the adequacy of our existing laws to suppress the varied forms of race-track betting, the effect of the provisions of the charter of the New England Breeders' Club exempting that organization from the operation of those laws, the constitutionality of those provisions, the power of the Legislature to amend or repeal that charter, and any other matters regarding which you feel that their advice would be of value to you. With that information, certainty will take the place of conjecture, and you will be able intelligently and with confidence to determine your duty in the premises.

The manifest alternative to the denial of this petition, or to such an opinion from the Supreme Court as would leave the essential question still in doubt, would have been the demand for the recall of the Legislature to repeal the charter and to enact sufficient laws for the protection of the State against all like attempts to introduce race-track gambling or betting. There was great reluctance to consider the reconvening of the Legislature. It involved many unpleasant liabilities. Moreover, it was an expensive procedure. An opinion from the court was in every way most desirable, if a clear, decisive, and sufficiently drastic opinion could be secured. The Governor and Council took immediate action requiring the opinion of the court, and the opinion, when rendered, met every condition necessary to give security to the State against any possible results of the operation of the Salem race-track. The track was already in process of construction at an immense cost. The site of the track at a border town on the Massachusetts line had been chosen for easy access from Boston and the cities of eastern Massachusetts, as well as from the manufacturing cities of the Merrimack valley. 
While the proceedings for the protection of the State were going on, and after the announcement of the opinion of the court, the New England Breeders' Club maintained a supercilious and indifferent attitude, after the New York habit. The race-track was completed and the opening of the spring season was announced. On the first day books were opened and bets made as if nothing had been done. On the second day and thereafter all gambling ceased through the interference of the state authorities. The season went on without the usual accompaniment, but it was an empty farce. The fall season was opened, and carried on under like conditions and with like results. Then the enterprise was abandoned at an immense financial loss. The Salem race-track was as desolate as an abandoned farm. Through the aroused moral sentiment of the State, the prompt and adequate decision of the Supreme Court, the vigorous and determined action of the Governor, the New York experiment of ignoring the moral sentiment of a State and defying its authority in the interest of racetrack gambling had proved a monumental failure in New Hampshire. ${ }^{1}$

This active participation on my part in a matter of civic reform so closely bordering on politics, led some persons to assume that it meant a willingness to go further, and my name began to be mentioned in connection with the governorship. The first time, however, the suggestion came

1 For further details see the Petition of the Sub-Committee of the Committee of Tuelve to the Governor and Council of the State of New Hampshire, - a pamphlet of thirty-two pages; the opinion of the Supreme Court in answer to the order of the Governor for a ruling in the case, reported in the daily papers of the State under date of March 14, 1906; also an address at a mass meeting of the citizens of Manchester, January 14, 1906, on tne Repeal of the Charter of the New England Breeders" Club, reported in the papers of the next day, published in "PublicMindedness," pp. 177-88. 
out into any publicity I quickly suppressed it. I had already defined my position in regard to politics, as may be seen from the following clipping, taken from a Boston paper discussing the make-up of the delegation from New Hampshire to the National Republican Convention in 1900 at Philadelphia:

Concord, N.H., Mar. 26. - The name of Pres. Tucker of Dartmouth has been prominently mentioned in connection with the selection of delegates at large from this state to the republican national convention in Philadelphia.

Dr. Tucker puts a quietus on the movement in this letter to one of his trustees, who is also a prominent member of the republican party in New Hampshire:

"I have no knowledge whatever of the circumstances or reasons which led to the use of my name in connection with the republican national convention. But if you are in a way to say anything to those concerned in it, I think that you must make it clear that I am not in politics.

"One must be in politics in a responsible or an irresponsible way. For the latter kind of political dabbling, I have no respect whatever. And for responsible politics I have no time apart from the ordinary duties of a citizen.

"I remember having once said to you that I believed thoroughly in practical politics as an open field to-day for men of principle and capacity. I say this to college men and urge them to consider it in their ambitions.

"But I think that the plain condition of entering politics in any public way is that a man must be able to know all that is going on, so that he may know what to say, where to strike, and where not to strike. Unless a man has such knowledge as this his influence counts for nothing.

"Certainly I have no time for such a venture. The interests of the College are not only first, but for all practical uses prohibitive so far as other interests of a public nature are concerned, which require discrimination and public statement. 
"I think that this makes my position so clear that it is not necessary for me to mention any incidental matters in detail. When one passes into secondary reasons, there may be those for or against any such action which might be considered, but it is not necessary to take them up.

"I will thank you very much, if you are in a way to do so, to see that my name does not come before the convention, and if the suggestion is really under way, that my name is withdrawn."

Perhaps this letter to Mr. Streeter needs to be supplemented by my views on politics as a profession, according to the reference in the letter to my advice to college men. I quote from a Rollins Chapel talk on the "Distribution of Personal Power": ${ }^{1}$

Have we gone to the root of the matter in placing our reliance upon reform and in training reformers? Why not recognize politics as a business, as a profession? Why not train men to do the business right in the first instance? Why not start in with the idea of making a good politician instead of a reformer? Why allow so noble a science as politics to be broken up and to fall in pieces between the "statesman" and the "politician"? If the real power, delegated power, lies in party, then put your man, your whole man, in the seat of power. If that is the seat of authority, make it $a$ place, if not the place of honor. But, you say to me, do you mean just this? Would you advise us to go into practical politics as you would advise us to go into business or the professions? That is just what I want to say. I can see no more honorable or inviting opportunity for a firm and patient ambition than municipal, or under certain conditions, national politics. The apprenticeship is long. Temptations are not lacking. But the way is open. Difficulties are not insurmountable. If a good man gives the same attention to business that a bad man gives, he is more likely to succeed. The only drawback to a noble success in American politics is the unwillingness of the people to acknowledge and rightly estimate the fact, that politics repre-

1 Personal Power, pp. 94-96. 
sents delegated power, that it is too large a thing to be possessed through the inroads of personal enthusiasm. Politics is a territory to be occupied, where men may make their habitation, and live honestly, and be held in honor by their fellow men. The scholar may go into politics, if he will, but let him go there to gain a residence. Let him go to learn as well as to teach. Let him keep his faith in men, but let him be patient with them. Let him accept honor and rejoice in it, but let him rejoice most in the service he can render. Let him stand to his task, as men stand to whom are intrusted the honor and safety of the nation, that other men may do their work securely and in peace.

But while emphasizing, as I always did, the practicability of politics as a profession having for its essential end the public good, I tried to make it clear that there was a vast unoccupied field of public service within the limits of the common citizenship. In the preface to "PublicMindedness," which had for its sub-title, "An Aspect of Citizenship considered in Various Addresses given while President of Dartmouth College," I set forth the present lack of vision as well as of duty in regard to citizenship. The accepted definition of a citizen is that of "a person who enjoys the privileges of a city or a state." Citizenship is the "status" of a person enjoying these privileges. There is as yet no sufficient recognition, in idea or in fact, of the quality of public-mindedness as inherent in citizenship. If we wish to emphasize this quality we are still obliged to speak of "good" citizenship. The title of the present book is a reminder of this deficiency. It implies that the discrimination may fairly be made between citizens who use their citizenship to guarantee their private interests, and citizens who also use their citizenship with supreme regard to the public good. The title of the first address reproduced in the book, originally given in Carnegie 
Hall, November 17, 1905, was "Good Citizenship dependent upon Great Citizens"; the title of the second, originally given in Tremont Temple, May 25, 1906, "The Sacredness of Citizenship."

The public relations of a college president may become to him a kind of avocation. Literally, an avocation is a calling away for a time from one's vocation - not a neglect of it or an interference with it, for then it would defeat its own end as a diversion or relief. Travel becomes such an avocation even when undertaken primarily, as it usually is, on official or semi-official business. It changes most quickly the routine, the environment, the atmosphere of the daily work. Incidentally, it offers special facilities for uninterrupted work. The parlor car on a short trip or a sleeper on some long journey is a better literary workshop than the office. I recall with delight the compartment of a corridor car on the Santa Fé road which gave me the protection of four days of uninterrupted writing from Chicago to San Francisco. But the avocation of travel offers its chief relief in the change it brings about so naturally from the executive to the social side of the profession. I do not refer to formal social functions which may be very solemn and very tedious, but to those more personal associations through which one widens his knowledge of men of his own and of other callings, and enters more freely into the comradeship to which this larger acquaintance with men and their varied interests opens the way. I count intelligent and well-directed travel a vocational and an avocational asset of a college president. Whatever value it may represent to him personally may usually be credited in still larger degree to the college.

I think that I should extend this valuation of travel be- 
yond the range of the constituency of the college and even beyond the country. It almost goes without saying that a college president ought to know the local sources from which the college draws its men, and that he ought to know as far as possible those parts of the country into which the college pours its alumni. Such knowledge on his part is the only safeguard against provincialism, the unpardonable sin in a college president in so far as he assumes to be a man of affairs. As a scholar the escape from provincialism is far easier. Indeed, it is difficult to understand how a scholar, if he be sincere and courageous, can fall into this danger. The gates of knowledge all swing outward. But even within the range of the broadest scholarship there is need of an avocation which may help to make the vocation more real, to give it contact with things most human, to put it into the currents of the world. Of course this effect can be realized only through the experiences of the man himself, and of these experiences one is the result, as I have been urging, of well-directed and intelligent travel. As I am writing these lines, the news has just come of the surrender of Constantinople to the Allies. Ever since the War has assumed its world proportions, I have felt that wherever the military decision might be made, the political decision must be made there, where alone the whole world was within reach. Many students of history and of current events have expressed this view. Such had been my own view from the limited study I had been able to give to the problems of the near East. But I date my impression of the meaning of the possession of Constantinople in the struggle for empire or in the struggle for international peace, to the sensation new, strange, and lasting which came upon me as I crossed for the first time the Galata 
Bridge-here, I said to myself, is the meeting-place of the races, here it is still East and West.

\section{VII \\ Two Years of Crippled Leadership}

In his more than Emersonian essay on "Work and Play," Horace Bushnell develops the theory that play is not the antithesis of work, and is therefore not to be defined in terms of sport, or recreation, or rest, but that it is rather the normal expression of work at its best, a state in which one reaches the highest degree of enjoyment. "In short," he says, "we are to conceive that the highest and complete state of man, that which his nature endeavors after and in which only it fulfills its sublime instinct, is the state of play." Dr. Bushnell's philosophy of work and play touches the vexed question of the relief of physical and mental strain. One theory finds the necessary and apparently sufficient relief in the reduction of the hours of labor the theory of industrialism. To what extent this relief, when it shall be fully brought about in the manual occupations, will prove to be satisfying, must depend on the use of the leisure thus secured. For the theory leaves out of account the relief which lies in one's interest in his work. It makes work altogether work with no play in it. All the play element in life must be found outside and apart from work. The other theory emphasizes in different ways the Bushnell conception of "work and play." It is the only possible theory which can be applied to professional life, and to those callings in which the wear and tear lies in the constant pressure of responsibility. The principle of an eight-hour day has no application to the professions except in a superficial way to teaching. In the 
professions a man must be a law unto himself in his use of time, the governing factor being his temperament or the specific nature of his work, like that of the doctor. The great distinction as it now exists under the reign of industrialism between the manual laborer and the professional worker is the lack of interest, certainly of relieving interest in his work on the part of the former, and the excess of interest on the part of the latter, an excess which may defeat its own end. In his case the play of the work may simply intensify it, passing altogether beyond the bounds of relief.

I confess to having adopted Dr. Bushnell's theory of the play element in work quite unconsciously, but when I began to consider in a practical way the question of work and rest, I found that the theory had become a governing idea. I had occasion at times to discuss the matter with our family physician, Dr. William T. Smith, Dean of the Medical School, who took exception to my theory and still more to my practices. Dr. Smith was a man of great sanity of judgment, which at this particular point had been confirmed by his own experience. His early professional life had been arrested by a nervous disability from which he had slowly recovered. It is but fair to him to say that he gave me frequent cautions, and endeavored to moderate my working pace, but my natural temperament and the exigencies of the day often led me to override his advice. I counted also very much upon my fondness for outof-door life and so long as possible upon out-of-door sport. When tennis became too violent an exercise, I tried golf, but golf was too manifestly an old man's game when approached from age, and therefore no game at all - only a certain "mode of motion," or at best a gamble with nature. 
I did not, however, neglect the ordinary reliefs of the summer vacation, especially after the work of reconstruction was well under way. In the summer of 1902 I bought a cottage on the river at York Harbor. This was next below the old Sayward house, the original home of Judge Sayward, Mrs. Tucker's great-great-grandfather. This ancestral interest, taken in connection with the beauty of the spot, had already led Mrs. Tucker's sisters to turn to York Harbor for their summer home - Mrs. George I. Rockwood and Mrs. Leonard Wheeler of Worcester, and Miss Cheever of Smith College. The early associations of the family with colonial history added greatly to the interest of our summer sojourns. The deciphering of Judge Sayward's diary, extending over thirty years and covering the whole period of the Revolutionary War and the subsequent constitutional era, gave us many entertaining evenings, owing to the personal idiosyncrasies of the author and the glimpses into the local history of the Revolutionary times. Among the summer residents with whom we formed most pleasant acquaintance were Mrs. Pratt and Mrs. Bell, daughters of Rufus Choate, both remarkable conversationalists. With Mr. Howells as guest at their table, the flow of wit was never interrupted, but one seldom saw such unconscious recognition of mutual rights in conversation.

I had reminders beyond the cautions of my physician of lessening powers of endurance, but I still relied upon my power of quick recuperation and kept at work, as it proved, too near the breaking-point. The break came suddenly, anticipating by two years the time upon which I had calculated for a safe retirement.

Near the close of the winter of 1907, upon my return 
from an extended and arduous trip among the alumni, I suffered from an undefined attack which developed into a severe and protracted illness. The unusual feature of this illness was my inability to respond to the ordinary treatment for a sickness of like symptoms. My power of recuperation which till now had not failed me was at a low ebb. And yet it was not, according to the diagnosis of the attending physicians, nervous prostration. Their final diagnosis traced the cause to a subtle but serious impairment of the heart, and their advice was to the effect that I must give over the hope of further active service of any essential value to the College. Of course this meant my resignation. As soon as I was able to understand the real significance of their decision I dictated the following confidential letter to the Trustees. The letter was sent to each individual member of the Board. I was anxious that the decision which I had had time to accept as a finality, should be given time to reach with them a like result before it should be given to the public. I also had the hope that they might be able to hold the matter in hand until they could at least make progress in the selection of my successor - possibly to announce his election in connection with my resignation:

To the Trustees of Dartmouth College:

For the last eighteen months I have been conscious of an undefined physical disability which has given me at times serious embarrassment, especially in meeting public engagements. The sudden and somewhat protracted sickness through which I have been passing has revealed the cause, namely, an impairment of the heart. My physicians, Drs. Smith and Gile, advise me that I cannot expect to do further efficient executive work. I take the earliest opportunity to apprize you of their decision, and to place before you my resignation of the Presidency of the College. I have long recognized the fact that there are no gradations in 
the work of a college president, in the way either of responsibility or of initiative. From the nature of the work there can be but one standard of efficiency. While therefore I anticipate by two or three years the natural time of my resignation, I do so with prompt and cheerful acquiescence in the law of all administrative service, which makes no provision for crippled leadership. I now return to my books from which I virtually parted company when I assumed the absorbing duties of the presidency. If it shall seem to you to be a useful service, and in other respects wise, I shall be glad to retain an informal connection with the College through one or more courses of lectures, open to seniors, upon the general subject of the "Formation and Expression of Public Opinion in a Democracy."

I cannot put by these fourteen years of service, happy in their associations and inspiring in their purpose, without a word of grateful acknowledgment to those through whom the service has been made one of mutual obligation and delight - first to you for your steadfast and unwavering support, and then to the faculty, and to the students of successive classes, and to the alumni, each and all of whom have contributed everything in their power to the common end. With such coöperation no reasonable good to the College has seemed unattainable. The things which remain to be accomplished, very much larger than any which have been wrought, go over with equal incentive and hope to other hands. I count it a joy that, as I now relinquish the position which you asked me as a graduate of the College to take, I may resume my place in the united and enthusiastic fellowship of our graduates, to add one more supporting force to the work of my successor in the Presidency.

I am in constant esteem

Most sincerely yours

W. J. TuCKer

Naturally it required some little time for the Trustees to convince themselves of the finality which the letter of resignation carried on its face, but after full conference with Mr. Hopkins, the Secretary of the College, 
who had been conversant with the exact state of affairs from the beginning, and after advising personally with the physicians, they addressed themselves directly to the emergency. There was one man to whom their thoughts turned unanimously for the succession to the presidency, Professor Francis Brown, of Union Seminary, but as at a previous time, his obligations to the Seminary were found to be paranount. It was impossible to act with like unanimity in the choice of any other person among the alumni or among well-known educators; and meanwhile the press was becoming persistent in its search for reliable information in regard to my condition. To relieve the situation, the Trustees asked if it would not be possible to withdraw my resignation for a few months, with immediate leave of absence, and with provision for all necessary relief from official duties should the chair remain unfilled at the opening of the next academic year. To this request I made the following response:

To the Trustees of Dartmouth College:

On the sixth of April, after the consultation of the doctors in regard to my present sickness, I communicated to you the result of their decision, namely, that owing to an impairment of the heart, it would be impossible for me to continue in the full discharge of the duties of the presidency. It seemed to me so essential that the duties of the office should be maintained in full efficiency that I placed before you my resignation - " $\mathrm{Al}$ though," as I then wrote, "I anticipated by two or three years the natural time of my resignation, $I$ do so with prompt and cheerful acceptance of the law of all administrative service which makes no provision for crippled leadership."

My letter was sent to you confidentially in the hope that you might be able to announce the election of my successor at the same time that you announced my resignation. Acting under the urgency of my desire, you endearored to bring about the 
result, but after earnest effort you found that this course was impracticable. You now ask me to withhold my letter, and to retain the general supervision of the College until such time as you may be able to give it over to my successor, without interruption to its work or policy. I had proposed, as you will recall, to retain an informal connection with the College by the service which I might render through a lectureship, but if in your judgment I can render a better service for the time being by continuing in partial executive work, I accede to your request. I shall be obliged, however, to act under the following definite restrictions - absence for the remainder of this year; and for the next year, or such part of it as you may require, exemption from much of the daily routine and from public engagements. I need not assure you of my desire and purpose to coöperate with you in all of your immediate plans for the maintenance and advancement of the College. I see no reason whatever for any change in the policy which has heretofore governed your action, nor for the slightest abatement of your efforts for the strengthening, or enrichment, or increase of the inheritance which you have the honor to administer.

I am

In constant esteem and affection

W. J. TUCKer

Hanover, N.H.

May 11,1907

At the date of this letter I was still confined to my room, though I had entered upon the stage of convalescence. As soon as my strength allowed, Mrs. Tucker and I left our home for Nantucket, where provision had been made by friends for our reception quite in advance of the season. No choice of a resting-place could have been happier. There is a delightful sense of remoteness about Nantucket, far enough at sea to emphasize its separateness from "the continent." Out of the season it has a still more delightful remoteness from the present. The daily steamer brings 
its welcome mail and certain supplies, but otherwise it is an intrusion. The island is quite self-contained. Perhaps the first impression on the mind of a visitor or guest is that of a real and genuine self-sufficiency. The streets of the old town so finely adjusted to its local needs and to its exercise of hospitality; the old but well-kept houses, of substance whether of brick or wood, their Captain's Walk, reminiscent of the early glories of the island; and the old wharves, though no longer lined with the ships of trade, still alive in the early morning or in the late afternoon with the fleets of smacks and schooners going and coming about the day's work - all these were a never-failing source of restful diversion. But the chief delight of the island both to Mrs. Tucker and myself was the long stretch of the moors, with their deep-rutted roads through the stiff sand, carpeted with vines and clustered thick with dainty flowers in the spring which turned to the rich berries of the fall. To lie in the open sunshine in the tangled grasses of the moors or on the sands, was to take the healing tonic of Nature at its best, to feel the subtle invigoration which comes through the relaxing of the muscles and the easing of the whole tension of body and mind. During the stay on the island I was under the professional care of Dr. Grouard, a young physician highly trained in the schools at home and abroad, who had established himself on the island, whose practice was as greatly valued by summer residents as by the inhabitants. I owe much to his sympathetic and skillful treatment of my case during this period of convalescence. Our home for the time, as indeed on later visits, was at Greynook, the house owned and managed by Miss Dexter and Miss Brayton, residents of Providence, but thoroughly at home in Nantucket. They had the true 
art of the hostess, knowing precisely what to do and what not to do for their guests. Greynook stood on the cliffs above the town, overlooking the breakwater and the harbor lights, and the open sea to the west. From our windows we could sight the "Nantucket" and the "Sankaty" soon after they passed the Cross-Rip Lightship on the homeward trip.

During my absence from the College the local duties of the office were discharged by Acting President Lord, assisted by Secretary Hopkins; and in the partial resumption of these duties on my return I was increasingly indebted to the active coöperation of both Professor Lord and Mr. Hopkins. The months of continued service, which had been promised to the Trustees, lengthened into the year, and the year into a second, while the unsuccessful search for a president went on. Outwardly the College kept its momentum. There was no diminution in attendance. Buildings which had been planned were carried to completion Massachusetts and New Hampshire among the dormitories, the Nathan Smith (Medical) laboratory, Webster Alumni Hall, and the enlargement of Rollins Chapel. The normal increase of the Faculty was maintained. An important addition to the annual resources of the College was introduced, in the action of the alumni at the annual meeting at Commencement in 1907, inaugurating a fund of yearly subscription for certain specified objects, after the manner of the Yale Alumni Fund. I was apprised of this action of the alumni while in Nantucket by the request through $\mathrm{Mr}$. Hilton that the fund bear my name. Nothing could have been more grateful to me at the time than to have my name associated with this constant and constantly increasing source of financial supply to the College. And I have 
shared in the gratification of the whole alumni body in the result of the subscription of 1917-18 through which the war deficit for that academic year was entirely wiped out, and a surplus left to be applied to special objects.

As I have already remarked, a college president upon retirement should not allow himself to indulge overmuch in plans for his successor to carry out. Each new incumbent of the office should have, so far as consistent with the necessary continuity of executive action, the unencumbered freedom of initiative. There were, however, at the time of the temporary withdrawal of my resignation, two plans affecting in different ways the interests of the Faculty that I had for some time had in mind, which I now relinquished with reluctance. One of them had to do with the increase of the productivity of the College in teachers of college grade. The deficiency of Dartmouth in this regard had begun to affect its own interests. There was of course the compensation, already noted, in the enforced obligation to other colleges for so large a proportion of its teaching force, that it insured the College against provincialism. But this safeguard was maintained at the cost of academic productivity. Experience was beginning to show that this failure of the College to produce in proper proportion its own teachers meant an educational as well as an institutional loss. The loss was manifested especially in the unstable and impermanent character of the lower grades of instruction. To remedy this state of affairs, several teaching scholarships and fellowships had been created. It was made a condition of receiving appointment to the fellowships that the recipients should hold themselves in readiness at the conclusion of their graduate study to teach for a year should the College need their service in the departments in which 
they were qualified to instruct. A further aid and stimulus to a larger interest in college teaching was indicated in the policy of more careful and generous recognition of such graduates as had already shown the requisite aptitude and attainments for positions on the Faculty, as vacancies might occur.

In the carrying-out of this purpose to increase the interest of the College in academic teaching, an incident occurred that disclosed a hitherto unsuspected sensitiveness in the relation between the professional and the executive conceptions of college administration. An election to an assistant professorship in one of the departments was to be made. Among the instructors was one of special qualifications for the position. His promotion would have naturally followed, had the fact not become known, through an interview, that his interest was altogether in a related subject lying outside the curriculum of a college, but included in the curriculum of a given university, from which university he hoped soon to receive an appointment. When asked if a continuance of his service in the grade of an instructor would be satisfactory to him while waiting for the expected transfer, he gave his assent to the proposal, and the election to the assistant professorship went to a well-qualified graduate, teaching elsewhere, on the ground that his election would give stability to the department. Of course this reason was specially evident from the institutional point of view. Exception, however, was at once taken by several members of the Faculty to the view and to the action following, on the ground that it was a professional wrong to withhold a merited promotion, because the instructor concerned could give no assurance of continuing in the advanced position if elected to it. It was claimed that in a pos- 
sible uncertainty about the tenure of a position, the benefit of any doubt should be given to a candidate for promotion rather than to the College in its institutional necessities. The incident aroused much feeling, but was soon closed by the acceptance of the instructor in question of an appointment to the expected position in university teaching. I felt, however, that the closing of the incident did not settle the question to which it had given rise; and had time and strength allowed, I should have addressed myself to an attempt at the settlement of the underlying question. It seemed to me then as now that the question should not be conceived as having two sides, but only as involving a common responsibility. The separation of the question into one of rights and responsibilities results in one form or another in the idea of arbitration. The solution of the problem lies, as I believe, in such a sharing of authority as will make the assumption of a common responsibility natural and necessary.

The other plan arrested by my resignation had to do with the inauguration of a pension system. I confess that I had not gone beyond the idea of a "non-contributory" system. That in fact was the only system then before the public. My distinct feeling was that it belonged to the College to provide the pension. I could see no logical reason why pensions should be assumed by an outside board any more than salaries in proportionate part. There seemed to me to be a decided objection in this partnership between a charitable board and a college, in the matter of meeting the annual expense of maintenance of the teaching force. The argument that a pension provided by a college would come to mean only deferred payment of salary suggested a liability, but did not to my mind imply a necessity. On the other 
hand, I could see that a pension drawn from an outside source might be more grateful to some members of a faculty than one drawn from their college could be. Pensions drawn from the colleges might fetter the movement of professors. An outside pension might conduce to greater mobility. If the idea of substituting insurance for free pensions had then been proposed, I do not know how it would have impressed me. It now seems to be in many ways a desirable as well as a necessary modification of the pension system.

I may add in this connection that while the pension problem was pending, Secretary Hopkins proposed a change in the terms of the Sabbatical year which made that system of much greater advantage to the majority of the Faculty than it had been, namely, the allowance of a half-year on full salary, instead of a full year on half-salary, leaving the choice to the individual professor.

At the beginning of the second year under the temporary withdrawal of my resignation, I gave the opening address in Webster Hall and later an address on the return to the enlarged Rollins Chapel, but otherwise I confined myself for the most part to office work. I attended the regular and special meetings of the Trustees, and as far as possible the meetings of the Faculty. Before giving over the year's work I prepared, at the request of the Trustees, a report of the period of my administration addressed to the alumni, the scope of which may be inferred from the introductory statement:

As my acceptance of the presidency in 1893 was associated with what was then known as "The Alumni Movement," the Trustees have thought it fit that upon my retirement I should make a separate and somewhat comprehensive report to you 
concerning the administration of the college during the period of my incumbency. In submitting this report I do not care to dwell upon outward results further than may be necessary by way of illustration. I am anxious rather that you should understand the principles according to which the college has been administered during a well defined, and in some respects dangerous, period in its history, namely, the period of reconstruction and expansion. Such periods are manifestly essential to the progress of our older educational institutions. Whenever the general system of which they are a part demands of them readjustment and expansion the risks of inertia are far greater than the risks of innovation. I know of but one qualification to this statement - the treatment must be constructive. Lord Curzon has remarked in a recent letter to the University of Oxford on the "Principles and Methods of University Reform," "We may learn from the experience of previous Commissions that successful reform at Oxford has almost invariably originated in reconstruction rather than in destruction; and that the institutions which last the longest and work the best are those which have been erected on older foundations, or, under skillful treatment, have assumed fresh and harmonious shapes."

As I interpreted the needs of the College, when I assumed the presidency, the policy of reconstruction with a view to expansion seemed to me to be the only adequate policy. There were at that time certain facts of very great educational importance to be considered: the vast extension of the subject-matter of the higher education, involving corresponding advances in the methods of instruction; the rapid growth of high schools as fitting schools for the colleges, virtually creating a new college constituency; and the sudden increase of endowments and appropriations for colleges and universities, making itself felt not so much in competition as through an enlarged scale of expenditure. It was impossible to ignore or evade any one of these facts. The obligation resting upon an historic college like Dartmouth to preserve its well-recognized individuality was no more evident nor imperative than was the requirement that it should relate itself effciently to its new educational environment. 
It is not to be inferred from the prolongation of my term of official service that the Trustees were not earnest and diligent in their search for a president. They carried on their efforts steadily, unhampered by any restrictive influences. They naturally sought at first a graduate of the College, but they did not allow themselves to come under this restriction. Of the two men with whom they conferred most fully in regard to the presidency, one was a graduate, the other was not. Their final choice fell upon one not a graduate of the College, but familiar with its inner workings through active service in an important professorship. It was with great satisfaction that they were able to announce shortly before the Commencement of 1909 the election and acceptance of Dr. Ernest Fox Nichols, then at Columbia. Immediately upon this announcement I sent the following communication to the editor of " The Dartmouth":

As there is no immediate opportunity of presenting Doctor Nichols to the undergraduates, allow me to give a word of introduction through your columns. Doctor Nichols belongs to our fellowship by the right of five years of brilliant service in the chair of Physics, a service recognized by the trustees by the honorary degree of Doctor of Science. But he is much more closely one of us by his sympathies. I have never attended a dinner of Dartmouth men in New York at which he was not present. He comes back to us as he left us, his heart unchanged. He returns with a reputation which has been increasing year by year at home and abroad. Few scholars in any department have gained the position which he holds as a man of forty. It is also his distinction that he has won his place in a department crowded with workers intent on research. The change which he makes to administration does not require of him the sacrifice or repression of powers which have given him success. Doctor Nichols is essentially a man of imagination. He sees things that are to be, as 
well as things that are. For this reason I anticipate from him as brilliant a service in administration as he has rendered in research or instruction. I anticipate no less that through his personality he will establish himself at once in the hearts of undergraduates and graduates of the College.

June 12, 1909

It had been a great pleasure to me to present the Trustees to President-elect Nichols at a meeting held just after his election at which he was present by request of the Trustees. And it was no less a pleasure both to Mrs. Tucker and myself to be able to present the Faculty and their families, and the students, to Dr. and Mrs. Nichols at a reception arranged in their honor at College Hall. In the discharge of this most happy function my official service practically terminated. I took no part in the formal exercises of the ensuing Commencement. The part which I took was much more personal than official - a virtual resumption of my place among the alumni through the following brief speech at the Alumni Dinner.

Through the very great kindness of Acting President Lord [he had conferred the degrees] and also of my old-time friend Professor Palmer of Harvard [who had given the Baccalaureate], I have been relieved of the more formal duties of the Commencement season. This relief enables me to sit at table with you today, and to take part briefly in the after-dinner speaking, though, I regret to say, through the written word. Very naturally my thought runs to-day to the relation between the transient and the permanent in our college life. This question of the transient and the permanent confronts us everywhere, but nowhere I think does it reach so happy a solution as here; for here we not only see, but feel, that the transient goes over into the permanent so naturally, almost so imperceptibly, and with such a compensating joy that hardly a sign is left of the change. And this for the very simple reason that a college is not so much an insti- 
tution as it is a movement, a procession. Nine tenths of all that pertains to a college is human, perhaps one tenth is material. I shall want to say something of the material embodiment of the College before $I$ close, for it is very precious. But the perpetuity of a college lies in this ceaseless movement of life, in this everflowing stream which reaches the sea only to replenish the springs. Here, for example, are two hundred men who are today passing out of the transient into their relatively permanent relation to the College. The undergraduate has his day. The coming years belong to the graduate. Go where he will, return as often as he will, present or absent, he is in and of the College. moving in its ample freedom.

Here again are men to whom the permanent seems to be passing back into the transient. The decades have gone which brought them to fifty, sixty, seventy, seventy-two years of graduate life. But here again the permanent is becoming the transient only to re-appear in the hope of a lasting permanency. Somehow our brethren as they become the men of the past seem to be nearer to the ever-living personality of the College than we are. I chanced to read the other day a reference of Mr. Choate to the words in which Mr. Webster brought the College before the Supreme Court, "I have brought my alma mater to this presence that if she must fall she may fall in her robes and with dignity." Those words were spoken ninety years ago. Who amongst us to-day are so much alive in our relation to the College as were the actors in that scene!

Here again we are come to a distinct change in the organized life of the College itself, a change of administration. Every administration stands for certain things which are relatively transient. When you have answered the questions which men so often ask, how much money, how many students, what new subjects, you have not necessarily said anything which relates itself very vitally to the future. These are only fragments of the great question which every administration has to answer, not what it has done for the College in the way of annual return of any sort, but further and chiefly, in what condition does it leave the College to meet the always urgent demands of its immediate 
future. What a given administration does to secure the success of the next is the test by which it must be judged. When I took over the College from Doctor Bartlett, there came over with the succession not only the effect of his intellectual character and achievements, but also the results of a brave, self-denying, sacrificing administration. The decade of the 80 's was a decade of financial struggle, sometimes expressing itself in sharp retrenchment, sometimes in persistent solicitation. It was in no small degree the resolute force of Doctor Bartlett, compacting the body corporate, at the price of much effort and no little hardship, which made possible the era of expansion which was to follow. The administration which now goes out must meet the like test. What has it made possible for the incoming administration to accomplish? How firmly is the College established to meet the issues which await it? President Lowell has recently said that probably three fourths of the American educators have ceased to believe in the college as an integral part of the educational system. That is not his unbelief, he declares emphatically. But in the reassertion of his faith in Harvard College as well as in Harvard University, he announced distinctly one impending issue in our educational world. As my successor must make answer to present criticism or unbeliefs concerning the college idea, is this College, now his college, in condition to enable him to speak with authority concerning its own future, and with assurance to others of its kind? It is for my successor to say, within the fair limits of the policy which he may adopt, what the immediate future of the College shall be. The present administration will have little or no value to him in this outlook, unless it shall appear that it has left the College in condition for him to say what its future shall be. According to the value of this contribution the present administration passes away into the transient, or it passes out of the transient into the permanent. Some of the younger among you have been accustomed to speak of the New Dartmouth. Our President-elect in addressing the undergraduates the other day spoke of the newer Dartmouth. That was right; the new is always passing over into the newer. So doing, it lives. If it were not for this process, a college would not grow old, it would grow stale. 
In the midst of the changes, however, which are involved as the transient gives way to the more permanent, it is quite easy to overestimate the element of change. Not infrequently the superficial aspects are emphasized. Not a little had been said in the daily press about the change of type represented in the election of a scientist to the presidency of Dartmouth College. I think that I have the mind of the trustees when I say that Doctor Nichols was elected to the presidency, not because he was a scientist in distinction from an economist, a classicist, or a psychologist, but rather because being a scientist, he had reached such distinction as to reveal the quality of his mind, and also because he had reached a position broad enough and clear enough to give him outlook in other directions. While he was with us it was always a delight to follow him, so far as one might, in his scientific researches; but outside his laboratory I thought of him as showing the spirit of the humanist or the idealist quite as much as the spirit of the more technical scientist. In the search of these modern days for a college president, trustees can discover the man only through his work, which to be significant must always represent some degree of specialization, but their search is no less for the man, and in the present case they are assured that they have found him.

I said as I began that nine tenths of all that pertains to a college is human, but that the remaining tenth, the material embodiment of the college, was precious. Always in the background of this steady movement of life stands the ancestral home. The generations of college men come and go, and come back again and again. Thirty-five generations of men have come hither and gone hence, returning year by year in increasing throngs.

"Though round the girded earth they roam

The spell is on them still.

"The mother keeps them in her heart

And guards the Altar flame.

"Around the world they keep for her

Their old chivalric faith." 
This is college sentiment. We must be careful how and where we apply it. When we apply it to ourselves as sons of Dartmouth, we may not use it to hide one another's faults or to exaggerate one another's virtues. Once out in the world where man meets man, we are in the open competition for honesty, justice, and charity. But when our hearts turn hitherward, we must not be afraid of sentiment. Let the mother of us all know, by visible and enduring signs, that you love her. Let her never be made ashamed, in any respect, for herself, not simply for her sons, as she stands with the years falling upon her in the midst of the older and the younger colleges of the land. Better yet, see to it that her strength is as the strength of the hills which guard her, and her beauty like their beauty, simple, true, sufficient. 


\section{CHAPTER $\mathrm{X}$}

\section{"THE NEW RESERVATION OF TIME"}

A Partial Resumption of Literary and Semi-public Work

When I closed the door of my office on July 15, the end of the fiscal year following the Commencement of 1909, I went to my home in much freedom of mind and with a certain exhilaration of spirit. It was with more than a feeling of relief that I entered upon my retirement. First of all, there was the sense of satisfaction that the College was at length relieved of the burden of the last two years of "crippled leadership," and was now about to pass into the competent hands of my successor. Then, in regard to my own future, there was the satisfaction of knowing its limitations. The knowledge of one's limitations ought to be a source of contentment, or an incentive to utilize the powers still available. In my case there was first the sense of contentment, which, however, soon gave place to incentives to further activities. The limitation which was most definite and absolute was the restriction upon public speaking, a restriction in which $I$ readily acquiesced. I had already become conscious before receiving the sharp reminder of physical disability in this regard, that public speaking has other dangers which threaten with the approach of age. There lurks in the habit, even in the discipline which makes one a ready speaker, the growing danger of substituting the practiced art for the thoroughly prepared thought. The necessity was not unwelcome to me which required for further public expression the change from speaking to writing.

But the chief satisfaction growing out of my retirement 
lay in the fact that it gave at once a new meaning to the home. When I came to Hanover I bought of Professor Arthur Sherburne Hardy the house which he had built on a lot in the college park. This house I enlarged to make it adequate for the social functions and the entertainment of guests incident to official relations to the College. It was an attractive house in a pleasant location and in many ways served admirably the uses of a home, but it was always associated more with the College than with the family. As it stood in the midst of college property and was held under the proviso that if sold the College should have the first right of purchase, the Trustees bought it upon my retirement and refitted it for continued use as a president's house. Anticipating this purchase I had bought a lot on Occom Ridge, immediately overlooking the Connecticut and commanding a view of the Moosilauke Range lying to the northeast. The house we built on this site, to the arrangement of which Mrs. Tucker gave much thought, was designed altogether for a home, and also to meet the changed conditions of the family life. As the household itself grew smaller the family circle was enlarged by new households. The home became the natural center for the Christmas holidays and for all special family occasions such as the marriage of the youngest daughter and the christening of the younger grandchildren. ${ }^{1}$

1 The oldest daughter, Alice Lester, is the wife of Professor Frank Haigh Dixon, for twenty-one years head of the Department of Economics in Dartmouth College and now Professor of Economics in Princeton University. Their children are William Tucker, Caroline Moorhouse, and Roger Coit (born on my seventy-fifth birthday). Margaret, the second daughter, is the wife of Judge Nelson Pierce Brown (Dartmouth, '99), of the Superior Court of Massachusetts. They have built a house in Hanover which they occupy as their summer home. Their children are Charlotte Rogers, Eleanor, Nelson Pierce, and Stanton. The youngest daughter, Elizabeth Washburn, is the wife of Frank William Cushwa, Odlin Professor of English at Phillips Exeter Academy. Their children are 
Once in our new home we were able to enter into the enjoyment of its local environment. Hanover lies in a region full of the most alluring opportunities to a lover of nature. It is in that part of the Connecticut Valley which is bounded on the Vermont side by the Killington Range, and on the New Hampshire side by the Moosilauke Range. Within a radius of ten miles from Hanover there are innumerable points on either side of the river from which one sweeps the enclosing ranges, and from which one may also reach, through breaks in the New Hampshire Range, into the region of the White Mountains. Declining the motor, and leaving the motor roads, we studied the old maps which gave the abandoned roads over the hills, and taking our courageous "Bess," and our alert pointer "Ted," we explored the neighboring country. I do not know whether our reward was greater from the nearer or from the more distant views. I had bought, some years before, an abandoned farm on the western slope of Moose Mountain, which commanded the Killington Range from Ascutney to Pico, giving also a glimpse to the north of Moosilauke. As time allowed, we used to drive occasionally to the farm (such only in name), but we were now able to put ourselves on familiar terms with the neighboring streams and hills within reach of one who could no longer tramp or climb.

The withdrawal from all public engagements allowed me ample time for such work as my strength would permit; but this qualification very materially reduced the value of the allowance. The situation was anomalous, for I found that the zest for work was not at all reduced in proportion

Charlotte Cheever and William Tucker (born February 21, 1919). My only sister, the widow of David Collin Wells, first Professor of Sociology in Dartmouth College, has continued to live in Hanover since the death of her husband in 1911. 


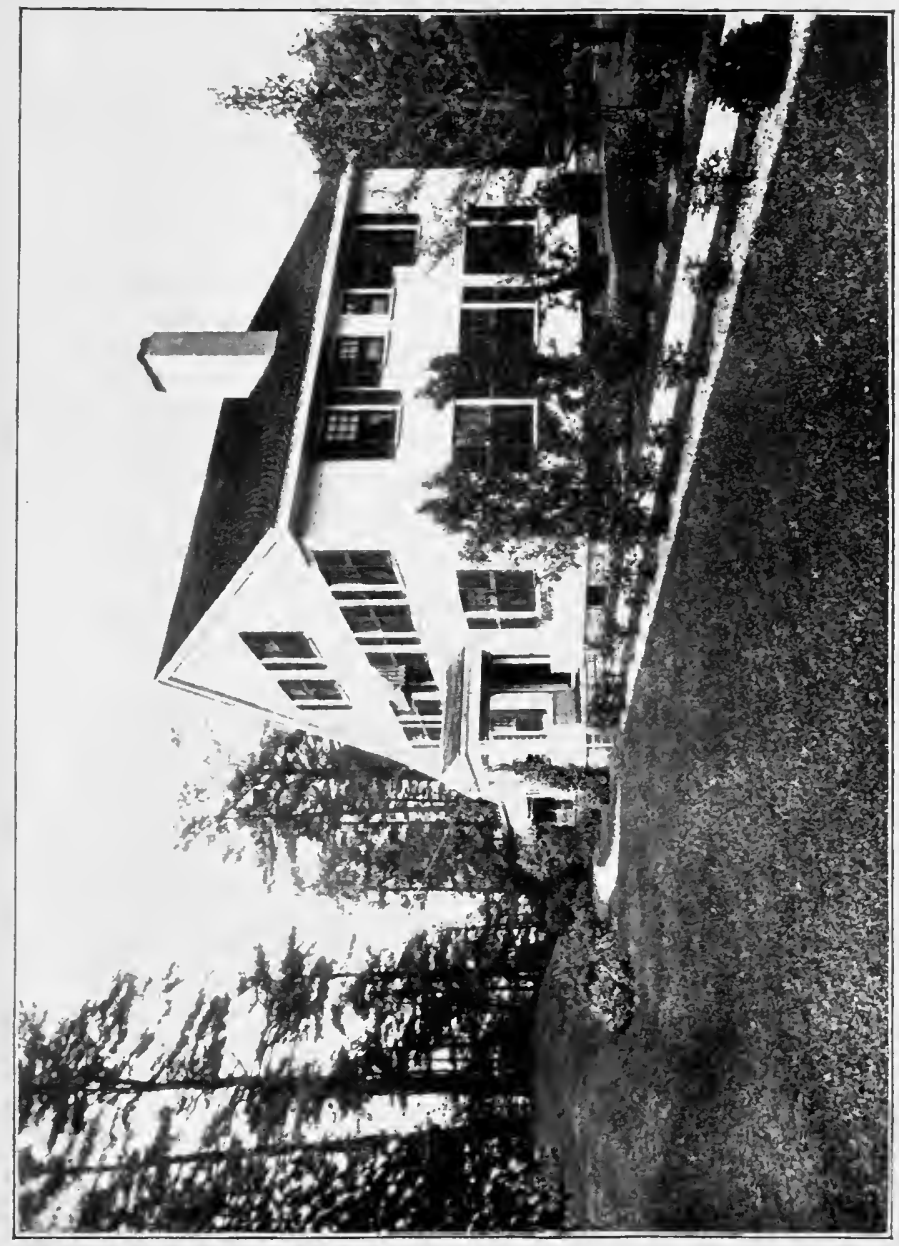

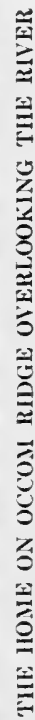



to the decline of working strength. This fact led me to reflect upon the status of those who under the new provisions for old age - chiefly retiring allowances or pensions were withdrawing from educational and other pursuits while still in efficient health. These reflections, emphasized by my own experience so far as it was in evidence, I embodied in an article for the "Atlantic Monthly," under date of August, 1910, entitled "The New Reservation of Time." In this article I endeavored to show the changed attitude in which it was possible under this "reservation" to approach

\section{“. . . that unhoped serene \\ That men call age."}

It is evident [I remarked] that a new principle has been set at work in the social order. Society is fast becoming reorganized around the principle of a definite allotment of time to the individual for the fulfillment of his part in the ordinary tasks and employments. The termination of his period of associated labor has been fixed within the decade which falls between his "threescore," and his "threescore and ten" years. The intention of society in trying to bring about this uniform, and, as it will prove to be in most cases, reduced, allotment of time for the ordinary life-work of the individual, is twofold.... The first intention is evidently to secure the greatest efficiency, in some employments the best quality of work, in others the largest amount. ... The second, if not equally plain intention of society is to make some adequate provision in time for the individual worker before he becomes a spent force. It therefore creates for him a reservation of time sufficient for his more personal uses. Within this new region of personal freedom he may enter upon any pursuits, or engage in any activities required by his personal necessities or prompted by newly awakened ambitions.

I am not now concerned [I further remarked] with the results which society seeks to gain in carrying out its first intention. I think that the intention lies within the ethics of business, and 
that the results to be gained may be expected to warrant the proposed allotment of time. But what [I asked] of the second intention of society? How far is it likely to be realized? What will be the effect of the scheme upon those now entering, and upon those who may hereafter enter, on the reservation of time provided for them? What is to be their habit of mind, their disposition, toward the reserved years which have heretofore been reckoned simply as the years of age? Will this change in the ordering of the individual life intensify the reproach of age, or remove it? Will the exceptional worker in the ranks of manual or intellectual labor, but especially the latter, who feels that he is by no means a spent force, accept reluctantly the provision made for him, as if closing his life-work prematurely, or will he accept it hopefully, as if opening a new field for his unspent energies? And as for the average worker, to whom the change will doubtless bring a sense of relief, will he enter upon the new "estate" aimlessly, or "reverently, discreetly, advisedly, soberly," and withal in good temper and cheer?

In my own case I was ready to respond to these questions with good disposition and intention, but it was impossible for me to base my response upon the assurance or expectancy of long-continued working strength. This fact precluded the possibility of a working programme. There were congenial subjects which invited careful and somewhat protracted investigation, but I could give myself no promise of any completed result. The limitations of health prescribed the range of my work in my study. There were two pieces of literary work at hand that called for nothing more than editorial revision. The first was the collection of various public addresses that seemed to have some permanent value, growing out of the occasions which called them forth, or the subjects which came under discussion, making up the volume already referred to under the title "PublicMindedness." The second was a collection of formal but 
intimate addresses given in the course of my official contact with the students of the College and associated with Rollins Chapel or Webster Hall, making the volume already referred to under the title "Personal Power." The former book answered its purpose as a repository of "occasional" addresses, and when the edition was exhausted, passed out of print. The latter has had a continuous sale, still following the successive college generations.

The only new work which I attempted at this time was the preparation of a monograph on "The Function of the Church in Modern Society" - one of a series on Modern Religious Problems, under the editorship of Dr. Ambrose W. Vernon, published by Houghton Mifflin Company, and later transferred to the Pilgrim Press.

In $1911 \mathrm{my}$ college class, known in its day from its wartime associations as the "Boys of '61," held its fiftieth reunion. Out of sixty-six who graduated, twenty-three were living, twelve of whom were present at the reunion. I had the very great pleasure of spending the leisure hours of Commencement with them, of presenting them to President Nichols, and of greeting them at my table for an evening of "good talk." I noticed that some of the men had grown rather abstemious in their diet, and that the hour of retirement had been moved back perceptibly, but otherwise it was the same as of old, except for the drawing a little closer together. The intervening years had obliterated all possible lines of difference, and out of varied experiences in life had brought us all to essentially one view of life itself. It was an occasion of good cheer touched with the humor of the seasoned wits of our number, and enriched with the reminders of things well worth remembering which had been said and done by the men of the class. 
This eddy in the current of the college life was also a pleasing reminder of my changed relation to the College. It is no strain upon the original meaning of the prefix in the title of ex-president to say that the "ex" means out of it, a meaning not limited to its application to time, nor yet changed in its scope when by the courtesy of the ruling authorities it is changed to the affix of "emeritus." I had always entertained this view of the honorable obligation of withdrawing from college affairs which should follow an executive officer into retirement, and was supported in it by the most admirable behavior of my predecessor, ex-President Bartlett. I had so announced my view in the closing words of my report to the alumni at the end of my administration. Referring to their responsiveness to my plans for the College I said to them:

I can ask for my successor nothing more and nothing less than the continuance of this spirit. I go further and suggest to you as alumni, that the most encouraging expression of this spirit which you can give to him is the assurance that you allow and expect on his part perfect freedom of initiative. The problems now before the College are not those of reconstruction and expansion. Whenever the new issues are defined, and the policy designed to meet them is set forth, the timely and effective ways of coöperation will disclose themselves. I am confident that the graduates of Dartmouth will not overlook or neglect the greater opportunities which lie in the immediate future of the College.

And now that my turn had come to put this view into practice, I found the practice not a duty, but a pleasure, made doubly pleasing by the cordial personal relations with Dr. Nichols, and by my interest as an alumnus in his plans for the College. It was very gratifying to me to see the heartiness and steadiness of the support given by the alumni and constituency of the College to President 
Nichols. His resignation after seven years, in the midst of successful service, to resume his professional work, was a surprise to me. I had not known the strength of the undertow which had been steadily drawing him back into the deeper waters of scientific research. His return to his earlier work was a conspicuous illustration of the greater hold which the special has upon some men above the general. Twice already in the history of Dartmouth its presidents had resigned to return to the profession.

It was to be assumed from my intimate relations with Secretary Hopkins that I should be peculiarly interested in the course of his administration when he was called to the presidency. I have been much more than interested. President Hopkins was confronted on his entrance upon his administration with those serious though general problems which had been already created by the War. Within a year the country itself was at war and the colleges became directly involved in it; at first, through their voluntary response to the call of the Government; later, through their militarization. As I have followed the course of President Hopkins in these circumstances, I do not know whether he is entitled to greater respect for the loyalty of his personal service to the government or for the sagacity of his management of the College - the boldness of his financial plans, the firmness of his adherence on behalf of the College to its educational standards. Many tests of educational leadership now await the presidents of our colleges, but the tests already made in the administration of President Hopkins give reason for confident assurance respecting the future of Dartmouth.

The course of events in the political world in 1912 brought me back to a renewed interest in social questions, 
and led me to take further part in the discussion of the principles and methods of social progress. In the national campaign of that year many of the active supporters of the general progressive movement urged the organization of the movement into a political party. To this purpose I was definitely and seriously opposed. I saw no more reason for this course than there was for the organization of the progressive movement in theology and religion into a new sect. Such a course in either case seemed to me to be a narrowing and belittling process, fraught in the case of the venture into the field of " practical politics" with all the dangers and distractions inherent in this kind of politics. My objection increased as I saw the attitude of so considerable a number of the Progressives toward Mr. Roosevelt. The singular obsession of mind in regard to him seemed to me to lead inevitably to an unworthy use of his splendid personality, even with his sanction, and to a consequent perversion of the cause itself from progressivism to Rooseveltism. The later action of Mr. Roosevelt in declining to perpetuate the "Progressive Party" organization, accompanied by his return to the Republican Party where his influence was much needed, brought back his personality to its normal use, a use to be greatly enhanced during the War by the call upon his patriotism. It was also a great satisfaction to the friends of Mr. Roosevelt and Mr. Taft that the unnatural estrangement, caused so largely by ill-advised partisans, should have been brought to an end before the death of Mr. Roosevelt, and the oldtime friendship so completely restored.

My protest, occasioned by the request of a weekly journal for the opinion of some persons in its constituency on the political situation, called out many replies both in private 
and in public, some in anger, some in grief. This effect was to have been expected in a political campaign, and required only passing attention, except in the case of some personal friends especially among younger men. But the situation itself led me to renewed study into the principles and methods of social progress. The first result of this more advanced study was an "Atlantic" article (October, 1913) on "The Goal of Equality." Relating this article to the Phi Beta Kappa Address on "The New Movement from Liberty to Unity," I acknowledged the arrest of this movement by the incoming of a new and more intense movement toward equality, the result in large degree of the rapid growth of class consciousness in the ranks of labor. I sought to interpret the meaning of this bold interruption by pointing out the failure of political liberty to secure the economic quality demanded. Liberty and equality, as I pointed out, are concerned with different objects, for under present conditions they operate within different spheres - the political and the economic. "What," I asked, "is the essential distinction between the political world of yesterday, from which we have inherited many unfinished tasks, and the economic world of to-day, which is confronting us with new tasks which are as yet mostly in the form of problems?" My answer was that the ruling conception of the political world was, and is, the conception of rights. The ruling conception of the economic world is the conception of values. Political progress toward equality - it has been very great - has come about through the recognition of rights. Economic progress toward equality, if it is to be equally marked, must come about through a like recognition of values.

In this distinction between rights and values [I went on to say] we have the reason of the present advanced demand for 
equality. The kind of equality now demanded is based not so much on the sense of rights as on the sense of values. The cause of equality inherits through democracy the right of equal opportunity. It is still the function of political liberty to guard the right. But new economic conditions call for an equality estimated in terms of value according to service rendered. My contention is that the satisfaction of this particular demand lies outside the province of politics, unless we accept the tenets of political socialism. The logic of the political invasion of the economic world, beyond the endeavor to guarantee equality of opportunity, is the socialistic state. . . .

The strike, for example, is a legitimate economic weapon; as a political threat it is utterly illegitimate. Carried over into politics, a strike becomes a revolution. Revolutionary methods have no justification except in the vindication of human rights. They have no place in the settlement of economic values. Should they be adopted by organized labor they would make organized labor a political outlaw.

Another article followed in due time ("Atlantic," September, 1915) of a more comprehensive character on "The Progress of the Social Conscience." After discriminating between the action of the social conscience and moral agencies with which it is often confounded, I said that its progress had been best reflected by the changes which it had brought about in public opinion, - the power which brings things to pass in a democracy. In confirmation of this statement, its progress was traced in the field of philanthropy, in the advance from charity to justice; in legislation, in the definiteness and persistence of the struggle with monopoly; in politics, in the new "sense of the State," indicated by the venture into "practical politics" even though in some respects a false move; in practical economics, in the sympathetic and determined effort to humanize industrialism; and in the field of social and civic 


\section{THE NEW RESERVATION OF TIME 425}

advancement, in the growing openness of mind toward the entrance of woman into civic life.

[In the original draft of this article, the moral determination evinced in the prohibition movement was cited in evidence of the progress of the social conscience, but this section was withdrawn in view of the excessive length of the article. Recently $I$ received a letter from one of the most sane and effective advocates of prohibition in which he wrote, "You taught me to respect prohibition." This word has always interpreted, to my mind, the necessary attitude of society to this method of temperance reform, if it is to be successful. There are unlikeable aspects of prohibition which society cannot be expected to ignore. Government is put to a heavy strain because of them in the adninistration of prohibitory laws. Society can learn to respect prohibition only as it reaches the stage of selfrespect in its treatment of the liquor problem. When it has reached this stage and has determined to free the nation from the mortgage of the liquor traffic upon the national resources and the national vitality, its respect for prohibition as the only adequate means of accomplishing this result takes the place of former dislikes and prejudices. The analogy at this point between prohibition and conscription is evident. Nothing could have been more unpopular or even revolting to many minds at the first than the substitution of the draft for enlistment. The present estimation of the draft accords with the result effected by it. We now see it in the light of its adequacy. Similarly the estimate of prohibition is changing, now that it has received the moral support of the nation. This new aspect is brought out in very striking terms in the leading editorial of the London "Spectator" under date of January 
25, 1919: "The decision of more than three quarters of the States in America to prohibit intoxicating drink is a political and industrial portent which no thinking person can disregard. . . . The one thing that is certain is that the American portent cannot safely be laughed away as the act of a few social experimenters and high-souled cranks. Right or wrong, practicable or impracticable, it is the considered word of a great nation."]

A somewhat detached article written on the occasion of the twenty-fifth anniversary of the South End (Andover) House entitled "Twenty-five Years in Residence" ("Atlantic," May, 1917), set forth the underlying principle of the social settlements, now numbering over five hundred, and the contribution which they had made to social and civic progress.

The Phi Beta Kappa Address, and the "Atlantic" articles, taken in connection with an earlier paper in criticism of Mr. Carnegie's "Gospel of Wealth" ("Andover Review," June, 1891), give whatever may have been distinctive in my advocacy of the new social order. Upon reflection, I renew the emphasis placed upon the relation of rights and values in a democracy. I am convinced that any political reconstructions in the interest of democracy which may follow the War, must be based upon a revaluation of social classes. Such an outcome is foreshadowed in the recognition accorded the views of the wiser English labor leaders. A full recognition of the new values to the State contributed by the producing classes, will do very much to make the democracies safe from within, and also to enable them to preserve their identity in the chaos of political ideals. A purely socialistic state, according to any accurate definitions of socialistic authorities, has more 
affinity with the Teutonic militaristic conception of the State than with the democratic conception of the AngloSaxon democracies.

With the advent of the War, the social question and all others of importance gave way before the supreme question of the hour. I refer to the War as a question advisedly. The mind of the world suddenly became one vast interrogation. The order of questioning as it emerged from the prevailing confusion was first, What was the occasion of the War, then, What was its cause? finally, What was its meaning? I have never felt that sufficient consideration was given at the time or later to the terrible tragedy at Serajevo which was the initial event. The reason, however, for this lack of consideration was evident. While the world saw that the occasion belonged within the racial conditions of the Austrian Empire and was disposed to a certain sympathy toward Austria, it soon saw with unmistakable clearness that the instigating and persistent cause was to be traced to Germany. But still the questions remained What did the War mean? What did it mean to Germany? What was the real content of the mind of Germany in which the War was conceived and by which it was nourished and maintained? In attempting to find sufficient answers to these questions, it seemed to me that we must go beneath the ordinary understanding of militarism, the term which had become the generally accepted explanation of the War. Militarism was the phenomenal aspect, sudden and startling in its appearance, but dangerous because it meant in the last analysis not so much the assertion or over-assertion of military power, as the assumption of moral prerogative. Beneath armaments and organization lay the political theory upon which militarism rested and from which it drew its life - the State is power. 
It was this view of the War which seemed to accord with the underlying facts and to give to the War its real meaning. It was in reality more distinctly an ethical than a military war. It surpassed other wars in the degree of its military organization and equipment; it differed from other wars in the new moral conception of the State which it thrust upon the world. Under the impulse of this sense of the meaning of the War, I wrote an article on its ethical significance - "The Ethical Challenge of the War" ("Atlantic," June, 1915), from which I take the following extract as showing its scope:

Whatever the War may or may not declare in regard to other matters, it calls the attention of the civilized world to the new moral valuation which it puts upon the power of the State. Tracing the war back to the teachings in which it had its origin, we find in them the constant idealization of power, at times almost the deification of it. The most authoritative teachings have been only an ampler statement of the Machiavellian axiom that the State is power. "The highest moral duty of the State is to increase its power." "War is the mighty continuation of politics." "Of all political sins, that of weakness is the most reprehensible and the most contemptible; it is in politics the sin against the Holy Ghost." It will give a proper background to these teachings to have in mind Milton's conception of the State: "A nation ought to be but as one huge Christian personage, one mighty growth or stature of an honest man, as big and compact in virtue as in body, for look, what the ground and causes are of single happiness to one man, the same ye shall find them to be to a whole State."

The question of the essential morality of power when embodied in the State, which is thrust upon us as the ethical challenge of the War, is the most serious public question which we have to face. Coming before us as a challenge, it calls us back to things fundamental, both in politics and in religion. To reverse in part Mr. Cleveland's saying, we find ourselves confronted, 
not so much by a condition, appalling as that is in which all nations are now involved, as by a theory which is likely to outlive the War, whatever may be its fortune, and to present itself to each nation for definition. It is a theory which has a most insidious fascination. There is no allurement so great when the mind turns to affairs of state as the allurement of power. Clothe the bare conception of power with the moral sanctities and it becomes not only alluring, but commanding. In this form it presents itself to us, and at a time of great doubt and perplexity in regard to subjects but lately in the category of commonplace realities - democracy, patriotism, and religion. Speaking with the assurance, if not with the audacity, of the half-truth, it says to us, Your democracy, your patriotism, your religion are obsolete. They are all guilty of inadequacy. If you would keep your place in the modern world, you must recast your fundamental conceptions of the State, and of the things which belong to it, in terms of power, and reinvigorate them with its spirit.

The views expressed in this introductory passage and in the subsequent discussion now seem quite commonplace, but as put forth at the beginning of the War, with the emphasis which they placed on its ethical character, they elicited much approval from men whose opinion I greatly valued. Among the letters received directly or through the office of the "Atlantic," I quote from two which were of special interest to me - one from a well-known Englishman, for many years Rector of St. George's Church, New York, the other of a more personal character from one of the Judges of the United States District Court.

The Editor,

Savin Hill, Ridgefield, Conn.

Atlantic Monthly

DeAR Sir,

Let me thank you for your part in giving to the public the quite masterly article by Mr. Tucker, "The Ethical Challenge 
of the Times." I have read widely the literature of the war, but this article seems to me in its lucidity, grasp, and supreme moral force, to stand almost in a class by itself.

I am, dear Sir, truly yours

William S. Rainsford

\section{United States District Court \\ New York \\ Judges' Chambers}

Dear Doctor Tucker,

May $30,{ }^{\prime} 15$

Yesterday's mail brought me the last "Atlantic." To-day I thank you with real earnestness for the most illuminating and guiding sermon, speech, or thesis as yet contributed to this crisis in world history. You have helped $m e-$ at all events - to think; a task which to most of us seems harder as years lengthen.

Very sincerely yours

Charles M. Hough

It may be of interest to follow the course of thought into which this conception of the War led as certain events or incidents seem to call for public treatment. I note the title of succeeding articles or communications called out by the moral trend of the War, and indicate by brief quotations the scope of the discussion.

"The Crux of the Peace Problem " ("Atlantic Monthly," April, 1916) - an exposure of the moral inefficiency of the peace movement on account of its failure to become identified with the righteous ends of the War.

The problem of peace, for such the peace movement has now become, does not lie in the conviction of its impracticability, unless it be deemed morally impracticable. The suggestion of the moral impracticability of peace seems like a contradiction of terms. Nevertheless, if we follow it but a little way, it will lead to the disquieting discovery of a very strong suspicion in the popular mind of a latent selfishness in peace; and further, after due observation and reflection, we shall be brought, I think, to 
see that the very crux of the problem of peace lies in the difficulty of eradicating this suspicion. The awful immoralities of war, so terribly obvious, are offset in part by the counteracting effect of the impressive displays of unselfishness.

War, in itself essentially evil, may acquire moral character as the instrumentality for serving a righteous cause. Peace, in itself essentially good, may lose moral character from the failure to identify itself with a righteous cause in the time of its extremity. I trace the popular suspicion of a latent selfishness in peace to its undefined and indeterminate attitude in so many cases toward ends outside and beyond itself. The constant insistence upon peace as an end in itself is to be deprecated. If we are to create confidence in the trustworthiness of peace to render that sacrificial service which is at times rendered so effectively through war, it must be made to wear a different aspect from that which it now presents to the world.

To the degree in which we fail to clothe peace with moral power, to identify it with the objects of moral concern, to make it the incentive and opportunity for sacrifice and heroism, we leave it under the popular imputation of selfishness. I follow out the danger from this defect in our advocacy of peace into sufficient detail to indicate the extent of the popular distrust, and to show the grounds of it.

"On the Control of Modern Civilization" (the last chapter of the book "The New Reservation of Time" - November, 1916) - a discussion of the responsibility of a given generation for the course of civilization within its limits, made urgent by the fact that no generation before was ever confronted so directly with the danger of an uncontrolled civilization.

Modern civilization has been by distinction a civilization of power. Its cultural effects, though clear and distinct, have been secondary. It has been a civilization of natural forces, of physical laws, of mechanical devices, of organization. The exponent of its power, and of its beneficence, is the machine. The progress of 
mechanical invention measures the advance of material welfare. We are all conscious that we have become the passive beneficiaries, or the passive instruments, of the civilization which dominates our lives.

In what has thus come to be the habitual reliance upon material power we have, I think, the explanation of the otherwise strange contradiction in the experiences of the modern man; on the one hand, a sense of power rising at times to arrogance, and on the other hand, a sense of helplessness involving at times an abject surrender to the environment. In our more confident moods we vaunt our alliance with the forces of nature, but not infrequently we are made to feel that we have to do with things which are irresistible and inevitable. Something of this sense of the irresistible and the inevitable has come over us in the retrospect of the causes, the agencies, and the instrumentalities which worked together toward the War. We see the steady, cumulative power of the material forces which were in operation. The retrospect discloses no counteracting human agencies at work equal to the task.

The War has ploughed deep into the life of individuals as well as of nations. Many of the questions which it has started are out of reach of diplomacy and statesmanship. The complete question is not the reconstruction of Europe, nor yet that of absolutism or democracy. There is, I believe, a growing sense that we do not reach the essential issues involved till we come into conscious and responsible relation to the civilization which allowed the War and brought it to so great magnitude. Any result, commensurate with the War, must consist in some corresponding change effected in the spirit and temper of the civilization which gave it its vitality and scope.

"Not Yet in the Name of Religion" ("Boston Evening Transcript," August 29, 1917, also a "Dartmouth College Reprint") - in reply to the proposal of the Pope for intervention in the interest of peace:

To find the true and sufficient ground for the world's indictment of Germany we must go back to that ancient formula put 


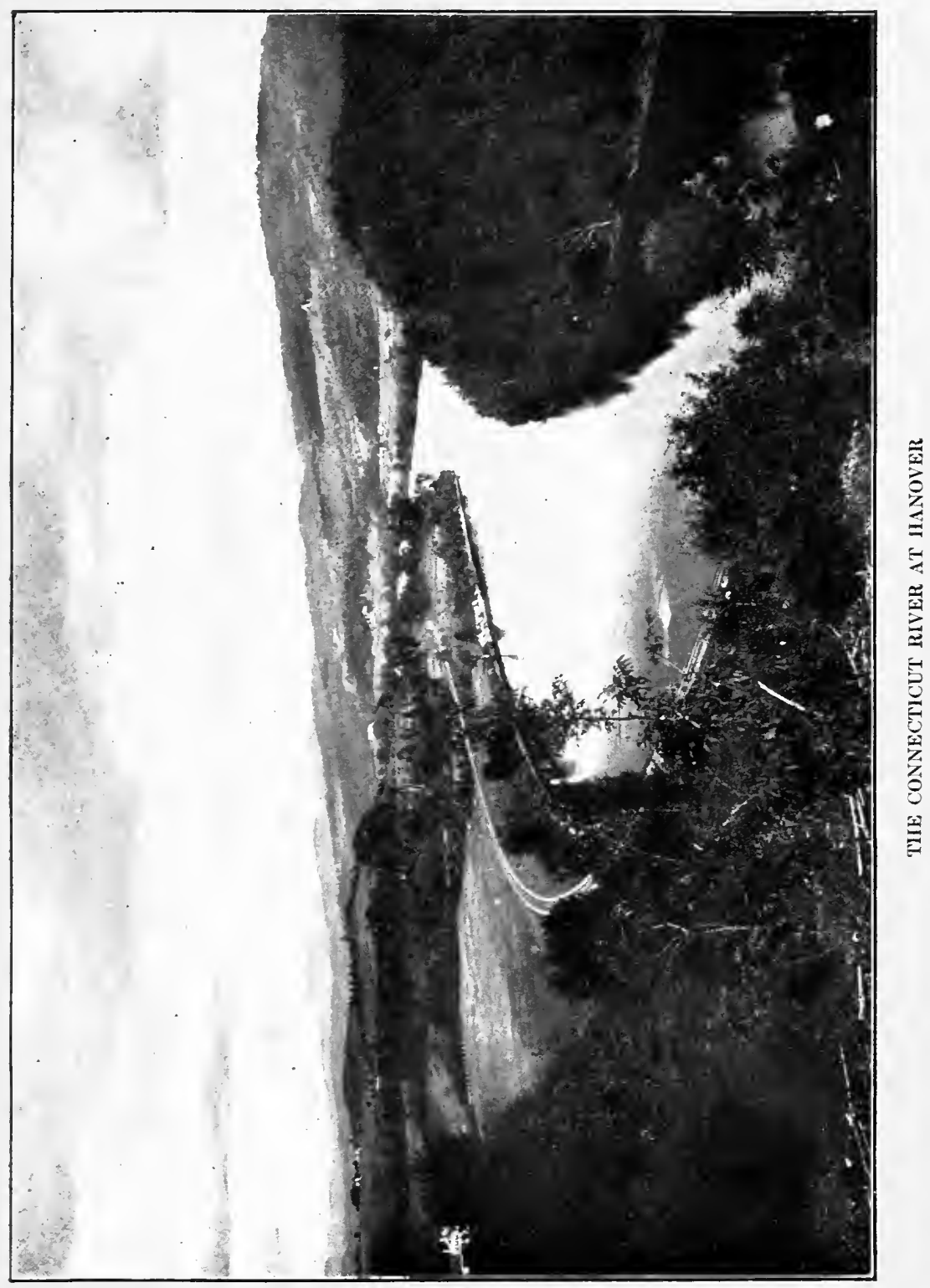



forth in the name of religion, which the world has accepted in its inexorable simplicity as the code of national as well as individual righteousness: "It hath been showed thee, $\mathrm{O}$ Man, what is good, and what doth the Lord require of thee but to do justly, to love mercy and to walk humbly with thy God." This code antedates Christianity. What article of the code did Christ repeal, or under what circumstances was the suspension of it wholly or in part to be allowed, or the violation of it to be condoned?

Germany, as the world knows, has persistently violated every article of the code. What is of greater present significance, the German autocracy has openly repealed the code itself. It has set up the worship of a new God, the God of Power, in whose name and by whose authority the virtues of justice, mercy, and humility are to be replaced by virtues better adapted to the exigencies of war. In the event of passing from war to diplomacy, we are asked to deal, on the ambiguous "principle of entire and reciprocal condonation," with the mind of a nation indoctrinated in the new code of national righteousness. In view of this proposal, that requirement of the ancient code which had seemed least pertinent to present conditions is seen to be highly important. What is to be the nature of the diplomatic approach to a nation which has divested itself of humility and is allowed to remain of unhumbled mind? It becomes necessary to have a right understanding at this point of the national mind of Germany, lest we find that it offers a greater barrier to an honorable and lasting peace than German arms.

The untimeliness of the proposed intervention was urged from the following considerations - first, increasing evidences of the unhumbled mind of Germany as seen in the spread of the cult of world dominion under the guise of Pan-Germanism; second, the absence of any clear insistence upon reparation in the proposed "intervention"; third, the greater timeliness of the entrance of the United 
States into the War as the most effective of all possible peace movements.

[The question of the mind of Germany still remains, under the marvelous change of conditions, the most anxious question of the Allies. On the one hand, it is not displeasing to see the earnestness of Germany in its efforts toward the reconstruction of the State on a more democratic basis. As I said in the article, "no sane man desires the humiliation of Germany." It is better for the world that Germany should be allowed to regain a place in the family of responsible nations than be forced to remain in a state of permanent outlawry. On the other hand, there is much unwelcome doubt about the attitude of Germany toward the vital matter of reparation. As I also said, "Reparation is the moral issue of the War, the moral condition of peace." There can be no moral conclusion of the War until Germany makes substantial amend for the terrible and wanton desolation of the War, and until she acknowledges the heinousness of incorporating into the practices of war the awful doctrine of atrocity and frightfulness. Possibly there is a ray of hope at this point in the exclamation of a German soldier, quoted with apparent approval by Maximilian of Baden, on the grounds of the feeling of the world toward Germany, "Heaven preserve Germany from emerging from this War without a character."]

To these public utterances I add the following communication to the "New York Times" of June 13, 1918, as touching upon a subject which has since become a matter of much discussion and of divided opinion, involving a certain amount of criticism of the position here taken:

To the Editor of The New York Times: I assume that all loyal Americans are in sympathy with the motives which governed 
the Board of Education in the City of New York in its recent ruling regarding further instruction in German in the public schools of the city, but I question if the reasons given for its action are such as will commend it for adoption as a national policy. The intellectual task which the nation has set for the generation now in the public schools is to combat German ideas, a far more serious business than to boycott them. This controverting of Germany within the whole field of the political moralities is the task to which the President has summoned the nation at large, not simply for national defense, but also for aggressive aid in behalf of the oppressed nationalities.

But the first step in controverting Germany is to know Germany. It is a bad beginning to deprive the coming generation of the ready knowledge of the rudiments of the German language. The answer of Germany to this "attempt to shake the morale of the German people by causing them to realize that this great city was unwilling to endure longer their language, and that it desired to break off thus more completely the possibility of intimate relations with them through the medium of language" will be, if consistent with past methods, to redouble the study of English in the German schools. Germany has never yet made the mistake of committing its propaganda to even the least conspicuous of its subjects without furnishing adequate and timely equipment.

Allowing the proper reservation of diplomacy and of political ethics to the experts, elsewhere, in trade, in travel, in the common intercourse of men the world over, the impending combat is to be one in which any man may take his part according to his trained intelligence. Unintelligent patriotism can evidently have little part in this field of patriotic endeavor. I deprecate any superficiality, or narrowness, or timorousness, or weakness of any sort in preparing the generation now in the schools for the really militant service which awaits it in the cause of international as well as of national righteousness. We tried to ignore the challenge of German Militarism. The result was national unpreparedness. Have we any excuse for a like unpreparedness in meeting the challenge of German Kultur?

William Jewett Tucker 
This criticism was directed against the proposed method of carrying on the intellectual combat with Germany. If we are to combat German ideas somebody must know German. To put this task altogether upon the colleges, at least in the elementary stages, would be undemocratic. To assume that such knowledge is unnecessary is simply a reversion to a state of mind corresponding to that which led so many to regard the militia of the country as equivalent to an army.

I can understand that there may be need of great modifications in the teaching of German in the public schools; I can understand that there may have been local reasons in some cities which justified the suspension of the teaching of German during the War; but to urge the elimination of German from schools and colleges as a definite national policy is, in my view, to urge a retreat rather than an advance, and is thereby sure, if the policy is adopted, to affect the national morale. Without doubt the movement is well under way. It has entered the stage of popular enthusiasm and popular satisfaction, the satisfaction which grows out of the feeling that something of consequence is actually being done. It is to be feared that it has yet to encounter those liabilities which marked the later stages of the "Know-Nothing" movement of two generations ago as it ran its rapid and sweeping career under the guise of superAmericanism.

As an example of sane and effective Americanism, the specific work in Americanization which is going on in many parts of the country cannot be too strongly endorsed. I quote from the programme of the New Hampshire Committee, the Honorable Frank S. Streeter, Chairman, the following statement of the object of the organization - 
"that all our citizens of whatever race should be able to converse and do business together in one common language is vitally essential for good citizenship and for the well-being and the preservation of a form of government like ours, the security of whose foundations rest solely on the sound public opinion of the electorate." As an essential means of carrying out this object the demand is made that all elementary instruction in the private as well as public schools of the State be carried on exclusively in the English language.

Here is something positive and constructive, of universal application and of permanent national value. In due time there may be fitly added to this demand the requirement of compulsory training in those principles and methods of the Government of the United States which have given it its distinctive place among the nations, and which have drawn to our shores so large a part of the non-English immigration of the past century. It is becoming increasingly and painfully evident that the insidious propaganda which is now undermining democracy abroad, is being introduced through various classes of our alien population into this country. The process of Americanization makes far-reaching demands upon our system of national education, and also calls for the most careful reconsideration of the principles and methods of industrialism. It is really a twofold task - to train our alien population in citizenship, and to train ourselves to the new and larger meaning of industrialism.

It is also to be noted in the further statement of the Committee that a foreign language (presumably without discrimination) may be taught in the elementary schools, provided the previous requirement in regard to instruction 
in the English language is fully complied with. This statement, though less urgent, is in harmony with the action of the ministerial boards of education in France and England in the public schools of those countries. The reports of the Ministers of Public Education in France and England, furnished in response to the request of the Commissioner of Public Education in this country, contain much of vital importance in their bearing upon the question at issue. These ministries positively refuse to eliminate the study of German from the public schools, having in mind alike the danger from German competition in business and from German propaganda. The assertion at this time by the United States of any kind of provincialism as a national policy would be entirely out of harmony with the policy of our Allies, and strangely inconsistent with our own action in assuming to lead the way toward a League of Nations of world-wide possibilities.

To complete the statement of views which $I$ have publicly expressed in regard to events attending and following the War, I insert with slight revision the letter written to the Dartmouth Alumni of Boston at their last annual meeting, in which I attempt to characterize that attitude toward participation in the affairs of the world which I conceived to be most in harmony with the spirit and policy that determined the history of the College.

Occom Ridge, Hanover, N.H. March 2, 1919

Edwin A. Bayley, Esq.,

President of Dartmouth Alumni Association of Boston My dear Mr. Bayley,

I have been greatly interested in the programme which you arranged for the present Dartmouth Dinner, in which you kindly invite me to have a part. My attention was specially arrested 
by your injunction, following the impressive list of the autographs of Dartmouth men in the service abroad, that we not only preserve the traditions of the College, but that we also "keep the faith." In asking myself just what the "faith" of Dartmouth is, in the keeping of which we may serve the nation in the present juncture of affairs, my mind reverted to a crumpled sheet of paper that had been lying for some years in safekeeping in my desk - the original manuscript copy, partly in ink and partly in pencil, of Richard Hovey's ode to the country on occasion of its venture into the world through the Spanish War. The ode bears, as you will recall, the striking title of "Unmanifest Destiny," and is in itself at once a rebuke to that national conceit which was then finding expression in the popular doctrine of "manifest destiny," and a plea for faith in the as yet "unmanifest destiny" of the country. I quote the closing lines -

"There is a Hand that binds our deeds

To mightier issues than we planned;

Each son that triumphs, each that bleeds,

My Country, serves its dark command.

"I do not know beneath what sky,

Or on what seas shall be thy fate;

I only know it shall be high,

I only know it shall be great."

To any one familiar with the ode, or to any one reading it for the first time, it will appear how naturally it rises above the occasion which called it out and fits itself to the "mightier issues" of the present. It will also become evident just what Hovey meant by the faith which can give to the nation the sure access to its "unmanifest destiny." And we have only to turn to our own history to see just how it works. The two great events which we commenorate to-night show us that this faith, reduced to practical terms, meant both to the founder and to the refounder of the College nothing more and nothing less than the power to adjust their minds to the greater issues that were to determine the fate of the College. That is what it must always mean - the power to adjust the mind to the greater issue as it arises. 
We accord the founding of Dartmouth to the faith of Eleazar Wheelock. What was the supreme exercise of his faith? Dartnouth College as we know it was not in the first intention of Wheelock. His first purpose and his long cherished project was his Indian School. That was "manifest destiny." For that he sent Samson Occom to England; for that he took his own way into the northern wilderness. He was then sixty years old, and apparently about to realize his lifelong desire, when the scheme became impracticable because of its insufficiency. It was then that the faith of Wheelock really asserted itself in the power to readjust his mind to the new and greater issue which had been hidden in the "unmanifest destiny" of his great conception. And it was then, because of his undaunted and discerning faith, that as the mirage of his Indian School faded away, there rose in its place the substantial walls of Dartmouth College.

The refounding of the College is still more a proof of my definition of the historic faith we are enjoined to keep. Why is not Dartmouth College to-day a State University? Simply because Mr. Webster could not adjust his mind to that conception of its destiny. You may say that he could not shrink his nind to that conclusion, or you may say that such was the audacity of his faith he would not harbor the thought. But the fact remains that it was Mr. Webster's obedience to the dictate of his higher nature, though acting contrary to the general advice of men from other colleges in New England, and under protest from some who feared to put the charters of their own colleges to a final test, that he determined to cast the fortune of his college into the lap of the Supreme Court and take the result. We know the result. We know that by this mighty venture of his faith, he gave to all colleges the lasting security of their chartered rights, and to us he gave back in place of an already established state institution a nationalized college, the significance of which return becomes more and more apparent as each annual catalogue adds to the enrollment of the sons of New Hampshire, the enrollment in increasing numbers of the sons of every other state from the Atlantic to the Pacific.

We can hardly fail to remind ourselves, as the keepers of this 


\section{THE NEW RESERVATION OF TIME 441}

historic faith, that the time may come, may even be at hand, which will test our power to adjust our minds to great educational issues that may vitally affect the College. I say no more at this point because of my firm confidence that whenever these issues present themselves they will be met with that breadth of view, and elevation of purpose, and resolute initiative which have already become characteristic of the present administration of the College.

But what of our attitude to the nation, the object of our immediate and urgent concern? Can we do better than try to apply this injunction that we keep the faith in the sense in which $I$ have tried to interpret it - as the power to adjust our minds to great issues as they arise? How constant and imperative has been the demand for the use of this power in our recent history. To recur to Richard Hovey's figure - with what rapidity have we been forced out of the region of our "manifest" into that of our "unmanifest destiny."

For a century we lived in the security and pride of our isolation. That was our providential assignment among the nations. That was our "manifest destiny." It took but so slight a cause as the Spanish War to disabuse our minds of that fallacy and adjust us to our place in the world.

Then came our experience of neutrality. That, we tried to persuade ourselves as we shrank from the horrors of war, was our "manifest destiny." Upon the high authority of our President we were assured for a time that this was to be our distinction. "We are," he said, "a mediating nation - the mediating nation of the world." This was a fit conception as applied to our internal life, that of mediating among the races and peoples of which we are "compounded," but as a theory of our relation to the warring nations it soon became unsatisfying, then disheartening, and then a burden intolerable to bear, an experience too bitter to endure. The day when we disowned our neutrality was a day of national emancipation. And to-day the joy with which we welcome our returning sons is in part the expression of our gratitude for our deliverance at their hands from our abject condition, into the community of the suffering but exalted nations. 
And now we are entering upon another stage in the disclosure of our "unmanifest destiny." What part shall the Nation take in the use of its sovereignty? Certainly this is a great issue, in the minds of many a very grave issue. But it is here, and how shall we meet it? I can only answer for myself. I cannot allow myself to believe that we shall put such a construction upon the doctrine of sovereignty as will block the way in the further advance toward the realization of our "unmanifest destiny." I believe rather that "we the people" will allow, and if need be, charge the Nation, in the full exercise of its sovereignty, to keep company with the great sovereignties of the world in the positive and determined effort to maintain the rule of justice, order, and peace. If a fellowship with this intent is to exist and we are not in and of it, where are we? If it shall not exist because we took no sufficient part in creating it, what answer shall we make to history for the relapse of the nations by consequence into the state of elemental warfare? 1

Such is my response, too long and yet too brief, to the injunction that we keep the faith - the faith, that is, of the open, the courageous, the undistorted, the unconfused mind in the presence of great issues as they arise. This is the power as I apprehend, perhaps the greatest gift of our inheritance as it is the greatest discipline of our citizenship, through which we as the sons of Dartmouth and as loyal citizens of the State are to strive to fulfill the "unmanifest destiny" whether of the College or of the Nation.

I am, in the fellowship of our faith

Most sincerely and heartily

William Jewett Tucker

I have recalled these expressions of opinion to mark the impression which the moral issues involved in the course of events made upon my own mind. Such studies as I was able to make in the endeavor to interpret the meaning of the new social order, or the meaning of the War, were for the

1 The portion of this letter referring to the national policy was taken note of quite generally in the daily and weekly press. 
most part embodied in articles contributed to the "Atlantic Monthly." I was much indebted to the generous hospitality of the "Atlantic" in this period of its renaissance under the editorship of Mr. Ellery Sedgwick. It gave me ready access to its wide constituency - a constituency made up largely of those whom I wished to reach. When I came to gather up these articles into a book to be issued by Houghton Mifflin Company, I was somewhat at a loss for a fit title. There was no unity of subject-matter. All that I could say of the subject-matter was that the order in which the articles appeared showed "the increasing seriousness of the subjects which occupied the public mind." On the whole, it seemed best to adopt the title of the first article in the "Atlantic" series as at least introducing a fresh idea "The New Reservation of Time" - following with the sub-title - "And other Articles contributed to the Atlantic Monthly during the Personal Occupancy of the Period described." The "Baltimore Sun," referring to the title, said: "This is an example of a good book hidden under the bushel of a bad title. No one would know without reading a part of the book what the 'new reservation of time' meant, and the term would not arouse the most curious book-buyer." Not so however the "Nation" and the "New Republic," both of which journals caught at once the underlying idea and proceeded to comment on it - the "Nation" making the title a text for discussing "Our ExPresidents of Universities," and the "New Republic" for discoursing on "Thinking at Seventy-Six."

The "Nation" (January 11, 1917), after touching with neat irony upon the need of a new "leisure class," which could not fit, well into the present "leisure class which plays polo and exhibits for the photographers of the 
Sunday supplement," offers our ex-presidents of universities as among the candidates well worth considering for the place, though distinctions must be made among them as they "differ among themselves in goodness, greatness, and glory," and then proceeds to a review of the motive and of the contents of the book:

Dr. Tucker's book set out to be an essay towards the solution of the problem: How to endure being a retired president. When he relinquished active charge of Dartmouth, he fell to considering whether the effect of society's creation by retirement of a quite elderly leisure class would intensify or remove "the reproach of old age." $\mathrm{He}$ answered the question in the new and inspiring spirit of resistance to superannuation, which makes so many men above seventy the admired companions of men in the twenties. He swiftly concluded that so far as his own case was concerned, membership in the leisure class was not a discharge from responsibility for time, but an admission to larger and freer opportunities to use it. His retirement permitted him at last to consider a college presidency as an avocation, and to follow what is perhaps the highest calling of a man of leisure - to think and write disinterestedly for the Republic and the cause of mankind.

Following an appreciation of the contents of the book, the writer reverts to this idea of a leisure class made up as suggested, and generalizes upon it in this wise:

Dr. Tucker is not the only retired university president who has in recent years been thinking and writing disinterestedly for the Republic and the cause of mankind; but he is perhaps the first to recognize his work as the fruit of a new and possibly important elderly leisure class. The precious aspects of membership in this class are various. Its members need not speak nor write except when moved by an inner call: they may therefore be expected to purge their utterances of the humdrum official platitudes of the bad days of their presidencies. They are scholars as well as administrators: they may therefore be expected to rise 


\section{THE NEW RESERVATION OF TIME 445}

above the violence of an uncritical partisanship. They are too old or too weary or too proud to enter into competition for such political honors as might be considered an augmentation of their sober academic glories; they may therefore be expected to speak weightily and to be heard gravely, as sage and unselfish counsellors of the national conscience. The class which we have been describing is really of quite distinguished morality and intelligence - it would be a hard class for a vulgar parvenu to enter; but it is a small class, and it ought to be enlarged by the accession of a few more men who have supped fairly full of honors say the ex-Presidents of the United States.

The "New Republic" (August 25, 1917) recognized equally the underlying idea of "the new reservation of time," but found the real significance in the fact that as applied to ex-presidents of colleges it gave them intellectual freedom after their long imprisonment in institutionalism. Making the application of this theory concrete, the reviewer says that "the impression a young man will get from this book is that to be institutionally responsible is to be intellectually suppressed and benumbed. Dr. Tucker does not say this, but he gives the effect of a mind that has been a long time in prison, the implications of his philosophy are so radical and yet his thoughts move so stiffly in their harness"; in proof of which he compares the views expressed on educational subjects with those on current social topics. "Here is a mind that has a driving radical force about it in any direction where it works openly and freely.... The marvel is to find in this thinker of seventy-six the dynamic philosophy which is only just beginning to be felt by young men of twenty-four." In proof of which latter statement, the reviewer comments in terms of highest approval of the views advanced in the chapters on social progress and on the War, and then passes to this generalization: 
What do we do in this country with minds like this, pregnant, radical, profound? Is it not a criminal waste of intellectuality to deny freedom to such minds except at the price of superannuation? Dr. Tucker has all the invaluable resources of the publicist. $\mathrm{He}$ is the stuff out of which England makes its Morleys and its Bryces. His style, though weighty, is distinctive, and could easily have been made as porous as Professor Dewey's. But our civilization could apparently find no other way of using such a mind than to put it for the best years of its life into the routine of a New England college, where the horrifying prestige of the higher education kept it in a state of torpor. Somehow at Dartmouth Dr. Tucker did not get himself tapped as a public philosopher. It is not until he is retired that he shows us in these essays what he might have been doing all these years as a publicist free lance. If President Tucker could not have had an earlier release, we are at least grateful for him now. May the years spare him an ever newer reservation of time!

This criticism forms a part of a unique literary episode. It is signed with the initials R. B. (Randolph Bourne), whose recent untimely death is so great a loss to the literature of sincere and searching personal opinion. In $1912 \mathrm{Mr}$. Bourne, while still a student at Columbia, appeared on the pages of the "Atlantic" in a brilliant essay on "Youth," full of freedom and fire. Mr. Sedgwick asked me if I would write a response to it - not in any way a reply - giving the antithesis of age. As I had already embodied much of my thought of age in my article on "The New Reservation of Time," I felt that any further word from me on the subject would be superfluous, and declined. I noticed that the antithesis soon appeared in the delightful article by John Burroughs on "The Summit of the Years." Some three years later, Mr. Bourne wrote an article ("Atlantic," September, 1915) on "This Older Generation," foreshadowed in degree by his article on "Youth," in which he charges 
that this generation of the elders has grown obstructive through its compromises and conventions, that it had failed to supply guides and leaders, and above all that it had grown "weary of thinking." To this indictment, Dr. Francis G. Peabody replied with admirable temper and good-humor, showing the futility of discussing too seriously the provinces of adjacent generations, but bringing out in sharp relief some of the characteristics of "This Younger Generation" ("Atlantic," December, 1915). At the close of this article Dr. Peabody, in answering the despairing question of Mr. Bourne - "Where are the leaders of the elder generation who are rallying about them the disintegrated members of idealistic youth?" - made reference to the fact that "Mr. Roosevelt was now several times a grandfather," and added, "or if still further any reader of the 'Atlantic' would observe how completely without age limit is the capacity to read the signs of the present times, let him turn back from Mr. Bourne's essay to the first article in the same number ('The Progress of the Social Conscience') and read the wise and far-sighted anticipations of an invalided veteran of letters, with their background of sound learning and their calm prophecy of a "revival of civilization.'" I do not know that this paragraph caught the eye of Mr. Bourne, or if so, suggested to him the opportunity of making his amende honorable to the generation, which he had accused of " having grown weary of thinking," through his very generous appreciation, in his review of "The New Reservation of Time," of one of their number as a "thinker of seventy-six whose dynamic philosophy is just beginning to be felt by young men of twenty-four." In the light of this possible, "amende" it seems almost ungenerous to call attention to the inconsistency of accounting 
for this storage of power during a long period of imprisonment in academic institutionalism, or to revert to another figure employed by the reviewer, to show how the "prison chill" could produce a "second blooming." However, Mr. Robert A. Woods, Head of the South End House, Boston, whose knowledge of previous facts was both intimate and critical, writing in the columns of the Social Settler ("Boston Evening Transcript," August 30, 1917), deftly relieved Mr. Bourne of the necessity of explaining the inconsistency by exploding the myth of "institutionalism." And so this interesting episode was happily concluded.

In defining at the outset the nature of this Autobiographical Interpretation, I remarked that its value would depend upon the relation of my personal career to the fortune of my generation. If the movements with which I was identified were born out of the spirit of the generation, and if in my connection with these movements $I$ also was imbued with its spirit, then I might hope to write as an interpreter rather than as a mere observer. The amount of ground covered by any or all personal activities would be relatively of less importance than a just appreciation of the spirit which alone could give them meaning and effect. But the spirit as well as the work of my generation has now passed into the secondary stage of interpretation. It is no longer to be studied and interpreted primarily with a view to service. The generation has said its word and accomplished or failed to accomplish its task. The War, while it lasted, was so inclusive and so insistent in its demands that it reached back among the men of my time to take account of their accumulated experiences as well as of their material possessions. What is now needed is not some past experience of the world, but a new spirit, 


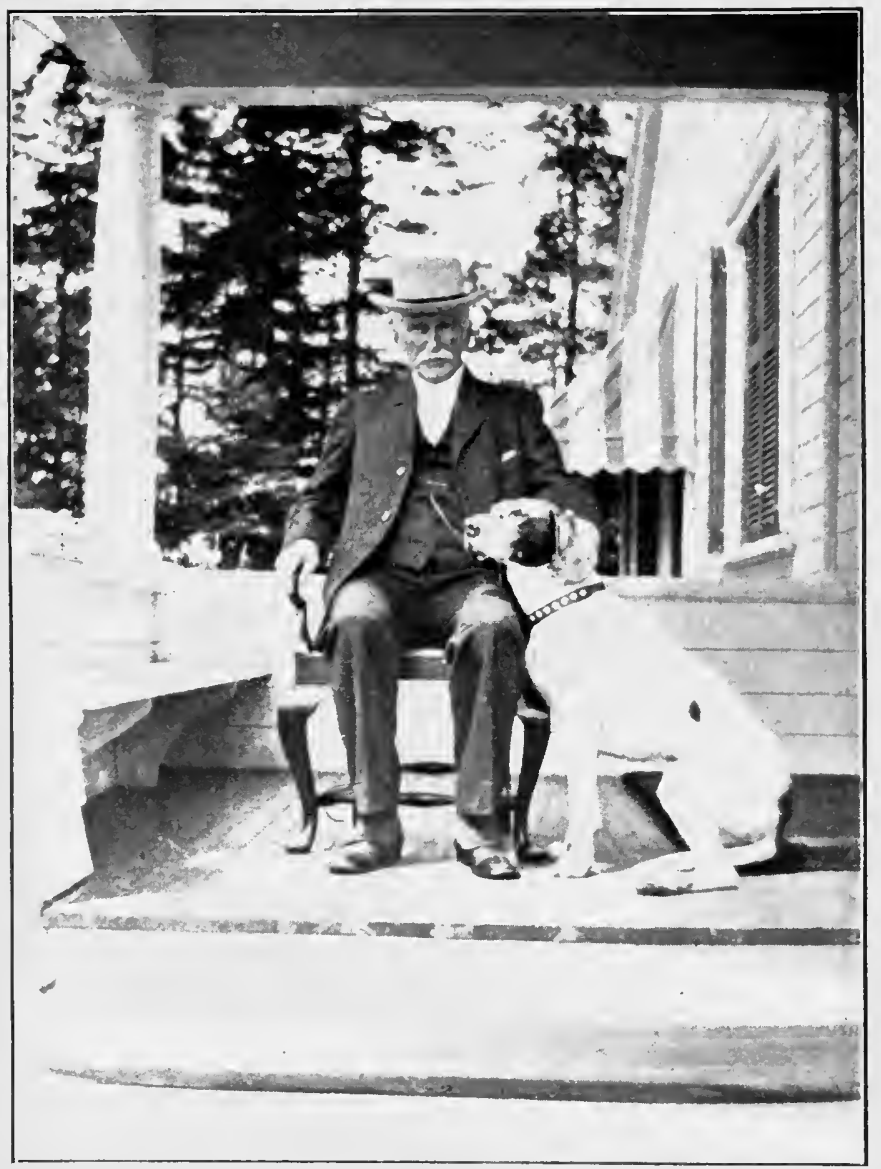

IN RETIREMENT 


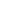


a new mind to be created out of its own aspirations, enthusiasms, responsibilities, hopes, fears, determinations, even out of the very chaos with which the War has seemed to plunge the mind of the nations.

Let me draw the contrast. The ruling idea, the dominating purpose, the passionate aim of my generation from first to last was progress. That one word explains its energies physical and moral, and its achievements, its mistakes also and its failures. The ruling idea, the dominating purpose, the passionate aim of the incoming generation must of necessity be peace - not peace as rest from the weariness of war, or even as recuperation from its awful losses; nor yet a peace satisfied with the dethronement of militarism or with the punishment and restraint of unhumbled and unrepentant peoples, but with peace as the commanding problem before the mind and conscience of all peoples, a problem having its only possible solution in the establishment and maintenance of the moral equilibrium of the world, the only balance of power which can be registered on the scales of justice. Evidently this object must be as far-reaching in time as in extent. Peace must be the world's business, its great business, for at least a generation. Any computation of the elements of a lasting, or really durable peace, must include vastly more of civilization, an adequate advance in the sense of justice, and the deepening of the process of humanizing the world. Any international court of justice must be supported and made practicable by continuous international legislation. Law, that is, must be superseded by better law and applied by better methods. So much our wiser men are beginning to foresee and to declare. But is this all? What shall prevent the spirit of war, once exorcised from the nations, 
from returning through the open door of class consciousness, enmity, and strife? Must the war of the nations be followed by the more terrible war of the classes? Who shall insure peace in the workshop and the market-place? How shall democracy be restated and reënacted in terms of economic justice? Surely the problems of peace can be no less absorbing, no less perplexing, than were the incitements and demands of progress.

Is there any word which the nineteenth century, as the century of progress, may utter in the ear of the twentieth century, as the century committed to the task of peace? There is one word which I believe it may utter without impertinence - patience. Soon or late, patience is seen to be the indispensable quality in the adjustment of human effort to the time element in the work of God in human affairs. "Forget not this one thing," said the Apostle Peter to the men of his generation, "one day with the Lord is as a thousand years and a thousand years as one day." How singularly applicable to the slow years of the War and to its swift conclusion! What if the War had ended before the Russian autocracy had fallen out of alliance with the liberty-loving peoples of the Entente; what if the War had ended while Turkey might have been saved by skillful diplomacy from permanent banishment from Europe; what if the War had ended before America had quickened her step to reach the battle-field at the critical hour? These are pertinent questions to ask ourselves as we turn from the issues of the War to the problems of peace. The problems of peace are already in evidence. They are growing more complicated and more serious. We cannot evade them, and we may not minimize them. Neither may we make light of the dissensions 


\section{THE NEW RESERVATION OF TIME 451}

that have arisen or that may arise out of them. "Nevertheless," shall we not say in like patient faith with that of the Apostle, as in his time he faced the obstacles to the incoming of the New Order of the World, "Nevertheless, according to His promise we look for a new earth wherein dwelleth righteousness." 



\section{INDEX}

Abbot, Samuel, 103.

Abbott, Dr. Lyman, his conception of the divinity of Christ, 131, 132; at Plymouth Church celebration, 370. Academies before the Civil War, 30, 31 . Adams, Professor C. D., 317.

Adams, Melvin O., 321.

Adams, Dr. William, 73-75.

Agnosticism, 6, 94.

Alabama, the. See Kearsarge.

Alderman, Dr., 19.

Allen, Archdeacon, 54.

Allen, Ethan, $37 \tilde{5}$.

Allen, Justice, 207, 208.

"Alumni Movement," the, at Dartmouth, 234-36.

Alumni Oval, the, 321.

American Board of Missions, 144, 145, $152-58$.

American Home Missionary Society, the, 63 .

Americanization, work in, 436-38.

Amos Tuck School of Administration and Finance, 321, 354-58.

Andover Controversy, the, out of place, 101; due in large measure to personal influence, 101, 102; the Board of Trustees and the Board of Visitors at the time of, 104, 105; election of Dr. Smyth, 105, 106; letter from member of staff of "Congregationalist" opposing Dr. Smyth's appointment, 107; effort of the "Congregationalist" to establish the theory of constructive heresy, 108-10; letter of the Faculty, 110, 111; conversation of Tucker with Smyth, 111, 112; letters concerning Smyth, 112-14; Smyth rejected by the Visitors, 114-16; effect of the decision on the public mind, 117-20; the Faculty of the Academy during, 124; distinction between "Andover Disturbance" and "Andover Controversy," 125; the early period a period of restraint, 126.

Andover Creed, the, 121, 122, 185221; Professor Smyth's defense of, 200, 216. See Andover Trial.
Andover House (South End House), 131, 181-83, 231, 367, 426.

Andover Movement, the, 128; expounded in the pulpit, 129; its relation to Unitarianism, 131-35; and the churches, 151.

"Andover Review," institution of, 136; contributors to, 137, 138; members of the Andover Review Company, Inc., 138; indebtedness to publishers of, 138,139 ; press notices of, $139 n$.; importance of editorials of, 139-46; the purpose of, 140-42; personal relations of the editors of, 146; the editors, 146-50; courses offered through, 174-77.

Andover Theological Seminary, a theological school with a missionary spirit, 55; Professors in, 55-57; intellectual and moral passion lacking in, 58; Tucker accepts call to, 86-89; its attempt to Christianize the doctrine of human destiny, 99 ; the constitution of, 102-04; new chair in, offered to Newman Smyth, 118, 119; Dr. Harris appointed to chair in, 120,121 ; resignation of Professors Thayer and Mead from, 121, 122; creed subscription, 121-23; the Faculty of, during the Controversy, 124; two new chairs established in, 124; status of, at the close of the preliminary stage in the controversy, 124, 125; the Faculty a preaching Faculty, 129; spirit of work within, during the controversy, 159, 184, 185; controversy without effect on students, 160; exceptional interest of the work of, 160; the Lectureship on Pastoral Theology, 161; the chair of Preaching in, 162; preaching by students at, 163, 164; lectures on the technique of teaching at, 163-65; scheme of lectures given at, 170-72; Social Economics in, 172-74; extension courses in, 174-77; Tucker resigns from, 240; period of institutional development of, delaved, 244, 245 ; decline in numbers, 245 ; re- 
moval to Cambridge, 245-47; creation of separate Board for, 246 .

"Andover Townsman," editorial in, on Professor Tucker's removal to Dartmouth, $239 n$.

Andover Trial, the, the charges, 18590; the reply of the Professors to the charges, 191-93; Professor Smyth's answer to the request to meet the cliarges in writing, 193; the Amended Complaint, 194, 195; the issue, 19597; the counsel, 197; the scene of, 198; the interest excited by, 198; absence of students and Trustees from, 198; the arguments, 198-202; result of, 203, 204; appeal to Supreme Court of Massachusetts made by Professor Smyth, 205; bill of complaint made by the Trustees, 205-07; verdict of Visitors set aside by Supreme Court, 208; changes in the Board of Visitors, 209, 210; complaint against Professor Smyth renewed, 211 ; case dismissed, 212, 213 , 233, 234; summary of the case, 213; result a personal triumph for Professor Smyth, 214, 215; folly of overuse of theological safeguards shown by, 216, 217; theological freedom assured by, 217, 218; contributed toward the freedom of Christianity, 219-21.

Arnold, Matthew, 81.

Asakawa, Professor, 346, 347.

Associated Charities, 172.

Athletics, college, 39, 332-35; at Dartmouth, 335, 336.

Arocation, value of, 392 .

Baldwin, Professor Simeon E., 197, 199.

Balfour, Arthur, quoted on the change in the point of view of the nineteenth century, 3.

Bancroft, Cecil F. P., 55, 104, 301.

Barker, Justice, 208.

Bartlett, Ichabod, 288.

Bartlett, Samuel C., 66 n., 310; President of Dartmouth, 65; resignation, 222; sympathies and activities of, 351.

Beecher, Henry Ward, 73, 332, 370.

Bell, Mrs., 396.

Bellows, Dr. Ilenry IV., 73.

Berkeley Street Church, Boston, 15456.

Berkeley Temple, 169.

Berry, Rev. Dr. Charles A., 370.
Bevan, Dr. Llewelyn D., 73.

Bible, historical criticism of, 6, 94-96; experiment in the constructive study of, $67-69$.

Biology as a study, 337 .

Bishop, Robert R., 104.

Bishop, Judge, 207, 238, 239.

Blair, Ex-Senator, 25.

Boards of control of colleges, 261 .

Boards of trust and colleges, 265 .

Bolshevism, 17.

Boston and New York, the religious atmosphere of, in 1875, compared, 72.

Boston Latin School, 31.

Bourne, Randolph, 446-48.

Boyhood in a New England village, 26-30.

Bradford, Dr., 370.

Brayton, Miss, 401.

Brooke, Stopford A., his "Life and Letters of Frederick W. Robertson," 58.

Brown, Charlotte Rogers, $415 n$.

Brown, Eleanor, $415 \mathrm{n}$.

Brown, Rev. Francis, President of Dartmouth, 287, 292-95.

Brown, Professor Francis, grandson of the Rev. Francis, 236, 237, 399.

Brown, John Crosby, 74.

Brown, Judge Nelson Pierce, $415 n$.

Brown, Mrs. N. P. (Margaret Tucker), 230, 415 .

Brown, Nelson Pierce, Jr., $415 n$.

Brown, Professor Samuel G., 236, 237, 366.

Brown, Stanton, $415 n$.

Burroughs, John, $4 \$ 6$.

Bushnell, Horace, on work and play, 394.

Butterfield, Dr. Ralph, fund given to Dartmouth by, 304 .

Cable, the Atlantic, $78, \boldsymbol{7 9}$

Cabot, Dr. Richard C., letter of, 366 , 367.

Capital and labor, changes in, after the Civil WTar, 14, 15.

Carnegie, Andrew, 178-80.

Carnegie Pension Fund, 265, 266.

Carter, President Franklin, 105.

Cass, Mr., 27.

Caverno, Rev. Dr. Charles C., incident regarding "Origin of Species" told br, 3 .

Chalmers, Rev. Thomas, 385.

Chapel, College, 345 . 
Charity, 172, 173.

Chase, Charles P., 311.

Chase, his "History of Dartmouth" quoted, $275,376$.

Cheever, Charlotte, wife of Professor Tucker, 230.

Cheever, Dr. Henry T., 230.

Cheever, $\mathrm{Miss}, 396$.

Cheney, Governor, 86.

Chi Alpha, New York club, 81-83.

Chicago, University of, endowment, 263.

"Chicago Times," the, suspension of, unwise, 45.

Choate, Rufus, 294, 396.

Christ, the new orthodox and the Unitarian views of, 131-35.

Christian faith, 220, 221.

Christianity, freedom of, 219.

Church, the, 17; and charity, 172; and social economy, 173.

Churches, New York, 84-86.

Churchill, Professor John Wesley, 124; personal sketch of, $149,150$.

Citizenship, Tucker's views on, 391.

Civil War, the, 8, 9, 11; moral relapse following, 12, 13; commemorative tablet at Dartmouth to students and graduates who fell in, 41 ; not unforeseen, 42 ; nation unready for, 43 ; popular impatience at beginning of, 43; disappointment in commanding generals in early part of, 43,44 ; political situation in, 44,45 ; the issue of personal rights versus national safety, 45,46 ; premature movement for peace, 46-48; carried on with a heavy heart in the North, 51; satisfaction at successful completion of, 52 ; characteristics of the era which followed, $52,53$.

Civilization, on the control of modern, $431,432$.

Clarke, Henry Steele, $6 \tilde{5}$.

Clarke, James Freeman, 138.

Classical college, the accomplishment of the, 37,38 .

Coit, Charlie, 22 .

Collective bargaining, 15.

College Hall. Dartmouth, 332 .

College presidency, 36z-64, 392, 403; emeritus, 420 .

Colleges, before the Civil War, 30; uniformity among, 31 ; curriculum of, 32, 33; competition in scholarship fostered by curriculum of, 33 ; predominance of personal element in teaching in, 33 ; numerical equality in, 34; educational aristocracy among graduates of, 34; the freedom of, 36 ; routine and the elective system, 36 , 37 ; the classical training of, 37,38 ; the earlier and the modern, distinction between, 38 ; significance of the present tendencies in, 39 n.; " college life," 39; comradeship in, 39, 40; corporate consciousness of, 249-71; the institutional character of, 249, 250 ; have spiritual value, 250 ; meaning of the phrase "corporate consciousness" as applied to, 250, 251; from address of Woodrow Wilson on, 252; criticism of educational spirit of, $253,257-66$; humanizing and individualizing in, 253-55; corporate spirit a stimulus to scholarship in, 255-57; governing bodies, 260-62; faculty responsibility, 261,262 ; nonsectarianism of, 262,263 ; endowments of, 263, 264; danger of capitalization of, 264; tendency to transform governing boards of, into financial boards, 264, 265; educational boards of trust in, 265 , 266; temptation to insufficient or inferior use of, 266,267 ; relation of, to the past, 267 ; prominence of teaching force in, in nineteenth century, 297; administration prominent in the modern, 297, 298; the modernizing process in, 297300 ; historic, the proper financial policy of, 302, 303; change in occupations of graduates of, 353, 354; humanizing function of liberal education of, 359,360 ; relation between professional and executive conception of administration of, 404, 405 .

Collins, Charles, 76.

Columbia University, endowment of, 264.

Comradeship, college, 39, 40.

Concord Reformatory, 169.

Congregational churches, examination of candidates for pastorates of, 151.

Congregationalism and Presbyterianism, 72.

“Congregationalist," the, 107-10, 210.

Conscription, 425.

Constantinople, 393.

Cook, Joseph, 55, 126.

Coöperation as a factor in evolution, 93.

Corporate consciousness, 249-71; meaning of the phrase as applied to colleges, 250,251 . 
Corporations, 15.

Corruption following the Civil War, 12.

Covel, W. J., 157.

Craig, O. H. P. (Captain Craig), 26.

Creed subscription, 121-23.

Crosby, Dr. Howard, 73.

Crosby, Dr. and Mrs. Josiah, $66 n$.

Cummings, Uncle and Aunt Noah, 26.

Curriculum, of colleges before the Civil War, 31-33; the modern and the oldtime, 38; significance of the present changes in, $39 \mathrm{n}$.

Cusliwa, Charlotte Cheever, $415 n$.

Cushwa, Professor Frank William, $415 \mathrm{n}$.

Cushwa, Mrs. F. W. (Elizabeth Washburn Tucker), 230, $415 n$.

Cushwa, William Tucker, $415 n$.

Dale, Dr., 81.

Dartmouth, Lord, 274, 276.

Dartmouth, Lord, the present, 276-78, $289 n$.

Dartmouth College, Indian School precursor of, 23, 272; its history to be capitalized, 269; college sentiment to be fostered, 269,270 ; question of facilities, 270,271 ; the traditions of, 271-96; a religious venture into an untried field of education, 272; refounding of, 272, 273; the romance of, 275,276 ; foundation of, 275,276 ; and the present Lord Dartmouth, 276-78; Tucker elected to Presidency of, 222; considerations for and against acceptance of Presidency, 228-25, 237; letter of declination, 225-28; the "Alumni Movement," 234-36; Tucker decides to accept Presidency of, 238 ; the proper institutional development of, 268,269 ; the Wheelock Succession, 280-83; occasion of refounding of, 283-85; charges and counter-charges, 285, 286; President deposed, 287; act of Legislature relative to, 287; suit and adverse decision, 287, 288; character of its graduates, 296,297 ; the modernizing process at, 300 ; management of, 300 , 301 ; contraction of, 301,302 ; financial policy of, 302, 303; funds of, 30308 ; independent heating and lighting system of, 306 ; the plant of, $307-09$; the physical expansion of, 309-12; arehitectural development of, 312; superintendence of construction at,
312, 313; educational expansion of, 313-15; changes in professional habits at, 315,316 ; committee system introduced into the Faculty, 316 ; coöperation of Faculty in reconstruction of, 316,317 ; distribution of, 317,318 ; benefactions of Edward Tuck to, 319-21; coöperation of alumni, 321, 322; normal capacity of, 323; immediate effect of modernizing process on internal life of, 323,324 ; coöperation of students used in reconstruction, 324-29; the elective system in, 324, 336-39; "Dartmouth night," 325, 326; "horning" and college sentiment, 326-29; introduction of the bath, 330 ; prejudice against the modern dormitory at, 330,331 ; the dormitory system at, 331, 33z; athletics at, 335, 336; and the University idea, 34953; the Thayer School, 351, 358, 359; Amos Tuck School of Administration and Finance, 354-58; lectureships established by Henry L. Moore, 361,362 ; and the State of New Hampshire, 373-77; Tucker's letter of resignation from Presidency of, 397, 398; during the time of continued service of President Tucker, 40z; need of academic productivity in, 403; scholarships and fellowships at, 403; incident touching relation of professional and executive conception of administration of, 404, 405; question of pension system at, 405, 406; Sabbatical year at, 406; election of Dr. Nichols to Presidency of, 408; speech of President Tucker at Alumni Dinner of, 409-13.

Dartmouth Hall, 312, 353.

"Dartmouth Night," $325,396$.

Darwin, Charles, publication of his "Origin of Species," 2; publication of his "The Descent of Man," 3; casual manner of introduction of the "Origin of Species," 3; influence of the "Origin of Species," 3.

Degrees, academic, 363 .

Democracy, $15,17,426$; conventions of, 329.

Denison, John H., 55.

Department store, the, 15.

Dexter, Henry M., 65; letter of, to the "Transcript," 195, 196: argument of, at the Andover Trial, 199; death, 209 , 210. 
Dexter, Miss, 401.

Dickens, Charles, 81.

Dickinson, Dr. Charles A., 155, 169.

Dike, Samuel W., 54.

Discipline, 1.

Disraeli, Benjamin, 5.

"Divinity of Christ, The," 143.

Dix, Dr. Morgan, 73.

Dixon, Caruline Moorhouse, 415.

Dixon, Professor Frank Haigh, 317, $415 n$.

Dixon, Mrs. F. H. (Alice Lester Tucker), 230, $415 n$.

Dixon, Roger Coit, $415 n$.

Dixon, William Tucker, $415 n$.

Dodge, William E., 74.

Dodge, William E., Jr., 79, 74.

Dogmas, 219.

Dormitories at Dartmouth, 308, 33032.

Dow, Professor L. H., 317.

Dunning, Dr., 210.

Duryea, Dr., 72, 116.

Dwight, Judge Theodore W., 197, 199.

Eastman, Professor John Robie, 301.

Economic crusades, originate in the West, 13.

Economic progress, 423.

Education, effect of scientific revolution of nineteenth century on, 6,7 ; liberal, humanizing function of, 359, 360.

Elective system, the, $36,37,324,336-$ 39.

Eliot, Charles, 309.

Emeritus, the term, 420.

Emerson, Professor, 315.

Emery, Professor F. B., 317.

Endowments of colleges and universities, 263, 264.

England, study of German language in, 438.

English language, study of, 437, 438.

Equality and liberty, 423.

Eustis, Rev. Dr. William T., his part in the Andover Trial, 105, 186, 193, 203-10.

Evil and good, 93.

Evolution, coöperation as a factor in, 93.

Faculty responsibility, 261, 262.

Fairfield, Arthur P., 313.

Farrar, Canon, 81.

Fayerweather, Daniel B., 305.

Fayerweather Fund, the, 305.
Fenn, William H., 66.

Field, Chief Justice, 208.

Field, Cyrus W., 78, 79.

Fiske, Daniel T., 104.

Fitchburg, Mass., sermon delivered by Tucker at, 126-28.

Foster, Professor H. D., 268, 317.

France, study of German language in, 438.

Franklin Street Church, Manchester, N.H., Tucker's pastorate of, 64-71; Semi-Centennial, $66 n$., 68; social expansion of, 69,70 ; the building, 70.

Fraternities, college, 332.

French, Judge Asa, 197, 199.

Gaston, Ex-Governor, 197.

Generation, Tucker's, character of, 1; fortune of, 1-18; purpose of, 2,449 ; moral heritage of, 7; the incoming, 449-51.

German language, the study of, 434-38.

Germany, the mind of, 434 .

Gilman, Gov. John Taylor, 376.

Gladden, Washington, 99, 370.

Gladstone, W. E., 178, 179.

Glezen, Mr., 167.

God, change in conception of, 92 .

Good and evil, 93.

Gordon, Dr., 370; on the modern orthodox view of Christ, 131, 133.

Gospel of Wealth, 178-80.

Graduate school, a contribution of the scientific method, 7.

Grant, U. S., a man of peace, 51.

Gray, Professor, 207.

Greeley, Horace, his letter in the "New York Tribune," 8; urgent for immediate peace, 46 .

Greene, Dr., 156.

Gregory, James C., 183.

Greynook, Nantucket, 401, 402.

Grimm, Professor H., 233.

Griswold, Conn., birthplace of Tucker, 20.

Grouard, Dr., 401.

Gulliver, John P., 124.

Hall, Dr. John, 73.

Hanover, N.H., 416.

Hanover Street Church, Manchester, N.H., 65.

Hardy, Alpheus, 104, 153.

Hardy, Alpheus H., 104.

Hardy, Professor Arthur Sherburne, 330,415 . 
Harris, Dr., United States Commissioner of Education, 30, 296.

Harris, Professor George, appointed to chair at Andover, 120, 121; personal sketch of, 147; coöperates in preparation of hymn book, 166, 167; form in which he accepted the Andover Creed, 202; testimony of, at the Andover Trial, 202.

Harvard University, endowment of, 263: Tucker as preacher at, 367, 368.

Haynes, Tilly, 198.

High schools, public, in $1860,30,31$.

Hilton, II. II., 322, 372 .

Hincks, Dr. Edward Y., 124; personal sketch of, 148, 149.

Historical criticism of the Bible, 94-96.

History as a study, 337 .

Hitchiock, Mrs. Hiram, 311.

Ilitclicock, Roswell D., 74, 76, 80, 81 .

Iloar. Judge Rockwood, 196, 197, 199, 216.

Hoar, Senator, quoted on the Harvard curriculum, 31.

Holmes, Justice, 208.

Home, cducation of, in a New England village, 28-30; the Puritan, 30.

Homileties, scheme of lectures in, 170.

Hopkins, President of Dartmouth, 321, 363 , 402; quoted on founding of lectureships at Dartmouth, 360-62; his presidency, 421 .

Hopkins, Ernest M., 319.

Hopkins, President Mark, 153.

Hopkinson, Judge, 289 .

"Horning," 326-29.

Hough, Charles M., letter to Tucker, 430.

Houghton, Mr. (Houghton, Mifflin \& Co.), 138.

Howells, Mr., 396.

Hunter, E. H., 313.

Huxley, T. H., 368, 369.

Hyde, William De Witt, 318; letter to Tucker on Newman Smyth, 112 n.; and the Maine Band, 183.

"Hymns of the Faith," 167, 168.

Individualism, 14, 16, 17, 97, 98.

Industrialism, 14, 15, 437; the theory of, 394 .

Initiative, intellcctual, 1.

Institutionalism in colleges, 260-66.

Intellectualisin in colleges, 259 .

James, D. Willis, 74 .

Jewett, Rev. William R., 22; Tucker taken into the household of, 24; his character, 29 ; death, 229.

Jewett, Mrs., death, 229.

Jewett City, 21.

Johns Hopkins, inaugurated epoch of graduate instruction, 7 ; endowment of, 263.

Johnston, Governor, 380.

Johnston, John Taylor, 74.

Jowett, Dr., 340, 345.

Kearsarge, U.S.S., and U.S.S. Alabama, presentation to, of Memorial Tablets by the State, 378-84.

Kellogg, Professor Vernon, quoted, 93. Keyes, Professor, 313.

Kimball, Benjamin A., 301.

King's Chapel, Boston, 134.

Kingsford, Dr., 309.

Knowlton, Justice, 208.

Labor and capital, changes in, after the Civil War, 14, 15.

Lacondaire, quoted, 135.

Lake, Dr. Kirsopp, 250, 251, 257.

Land and Water Power Company, Manchester, N.H., 64.

Lane, George W., 74, 75, 86.

Lanphear, Dr., 211.

Lathrop, Justice, 208.

Law School at Dartmouth, 351, 352.

"Laying of the Corner Stone of the New Dartmouth Hall," $289 n$.

League of Nations, Tucker's attitude toward, 438-42.

Learned, Bela, 22.

Leathes, Stanley, quoted, 16.

Leavens, Kirk, 2q.

Lecky, W. E. H., quoted, 273, 274.

Lecture platform, the, $9,10$.

Lectureship on Pastoral Theology at Andover, 161, 169-72.

Legge, Edward, 277.

Legge, William Heneage, 277.

Legge, William Walter, 277 .

Leisure class, 443, 444.

Leland Stanford University, 263.

Liberty and equality, 423.

Libraries, college, $3 \dot{q}$.

Lincoln, President, his reply to Horace Greeley's letter, 8; as an orator, 10; the return to, in the present war, 10 , 11; his second inaugural quoted, 11; his analysis of democratic government, 15, 16; his decisive statement of the terms of peace, 46 ; fceling toward, 47 ; sees little prospect of his 
reellection, 47; his view of the Civil Munger, Theodore T., 99.

War, 51.

Lord, Professor John K., 318, 350, 402.

Lowell, President, 341.

Lowell Institute lectures, 232, 364-66.

Lyceums, 10.

Lyman, Arthur T., 133, 134.

Music in church services, 166-69.

Nantucket, 400, 401.

"Nation," the, on Dr. Tucker's book, "The New Reservation of Time," $443,444$.

Macaulay, T. B., 364.

Madison Square, N.Y., 75.

Madison Square Church, the, Tucker called to, 71; organization and growth of, 74,75 ; consolidated with other churches, 85,86 .

Maine Band, the, 183, 184.

Manchester, N.H., character of, 64, 65; the churches of, 65,66 ; the pastorate of Tucker at, 66-71.

Manchester Locomotive Works, the, 65.

Manning, Cardinal, 179.

Mansfield College, England, 245.

Marsh, George P., 294.

Marsh, Joseph, 375.

Marsh, President of the University of Vermont, 138.

Marshall, Jonathan, 105, 203, 209.

Mason, Jeremiah, 25, 286, 288.

McKenzie, Rev. Dr. Alexander, 104.

McKenzie, A. A., 313.

Mead, Professor, 121, 122.

Mcdical school at Dartmouth, 352.

Merrill, James G., 54.

Merriman, Dr. William E., 155.

Merwin, Sam, 22.

Militarism, 427.

Miller, Judge, 45.

Ministry, the, colleges as training school for, 31; the personal element in, 54 ; wider interpretation of the call to, 54,55 ; the question of the pastoral and the educational branches of service in, 87.

Missions, "cut the nerve of missions," 109, 144, 153; city, 130; motive for, 144, 220; the American Board of Missions, 144, 153-58.

"Modernism," attitude of the churches toward, 90.

Moore, Professor George Foot, 124, $137,148$.

Moore, Henry L., lectureships established by, 361, $36 z$.

Morley, John, quoted on the tendencies of modern education, 37.

Morley, John H., 55.

Morton, Justice, 208.

Nationality, spirit of, and the slavery issue, 8-12.

"New departure," 125.

New England Breeders' Club, 384-88.

New Hampshire and Dartmouth, connection of, 373-77.

New Hampshire College of Agriculture and the Mechanic Arts, 351.

“New Puritanism, The," 370.

"New Republic," on Dr. Tucker's book, "The New Reservation of Time," 445, 446.

"New Reservation of Time, The," the title, 443-48.

New York and Boston, the religious atmosphere of, in 1875, compared, 72.

New York pastorate, limitations in, 82-86.

Nichols, President Ernest Fox, inauguration of, 280, 282; Professor in Physics, 317; and "Dartmouth Night," 326; accepts presidency of Dartmouth, 408; reception to, 409 ; support given to, 420; resignation, 421.

Niles, Edward C., 386.

Noble, Dr., $158 n$.

Northern Academy, the, 350.

Norwich, Conn., early home of Tucker, 20, 21; description of, 22,23 .

Noyes, William H., the ease of, 154-58.

Occom, Samson, 23, 274, 275.

Olcott, Colonel, 375.

Ordronaux, Dr. John, 331.

Ormiston, Dr. William, 73.

Pacific Theological Seminary, Tucker lectures at, 369 .

Palaeopitus, Dartmouth society, 329.

Palmer, Professor George H., 55, 135, 368.

Park, Professor Edwards A., Professor of Christian Theology, 55; theology as treated by, 55, 56; resignation of, 105; witticism of, 166; death, 209, 210.

Parker, Dr., 81.

Parker, Chief Justice Joel, 310, 351.

Parkhurst, Dr., 84. 
Pastoral Theology, lectures on, 161, 169-72.

Patience, 450, 451.

Patten, Professor William, 93, 317, 338.

Payne, Judge, 375.

Peabody, Professor Francis G., quoted, 347-19; at Dartmouth, 368; his reply to an article of Mr. Bourne, 447.

Peace, premature movement for, in the Civil War, 46; moral and selfish, 430, 431 ; the aim of the incoming generation, 449; the problems of, 450,451 .

Peaslee, Dr. Edmund R., 86.

Pension funds, 266.

Pension system in colleges, 405, 406.

Personal rights versus national safety, $45,46$.

Phelps, Professor Austin, 56, 57.

Phi Bcta Kappa Oration, 232, 233.

Phillips, John, 103.

Phillips, Phobe, 103.

Phillips, Wendell, 10.

Phillips Academy, 102.

Pilgrim Church, St. Louis, 71.

Pillsbury, Att.-Gen. A. E., 378.

Play and work, 394, 395.

Plymouth, N.H., Tucker removed to, 24,25 ; character of, 25; life at, 2630.

Plymouth Church celebration, 370.

Political effects of the change in the social order, 15, 16.

Politics, tone of, after the Civil War, 12, 13; Tucker's views on, 389-91.

Pollens, Professor, 317.

Pope, the, his proposal for intervention, 432, 433.

Porter, Judge John K., 76, 77.

Potter, Dr., 73.

Pratt, Mrs., 396.

Preaching, the chair of, at Andover, 162: 'Tucker's lectures on, delivered at Yale, 162, 163; by students, 163, 164 ; lectures on the technique of, 16365; has to do with the personality of the teacher, 164; methods of, 165 ; scheme of lectures on, 170-72.

Prentiss, George L., 74.

Presbyterianism and Congregationalism, 72.

Presidency, college, 362-64, 392, 403; emeritus, 420.

Pritchett, Dr., 266.

Professional schools, 349-53.

Professions, work and play in, 394, 395.

Professors in colleges before the Civil War, 33.
Progress, passion for, in Tucker's generation, 2, 449.

Progressive movement in theology, attitude of churches toward, 90 ; covered three fields, 91 ; in the field of theological inquiry, 92-94; in the field of historical criticism, 94-96; its humanistic impulse, 96-99.

"Progressive Orthodoxy," 91, 142.

Progressives, the, 422.

Prohibition crusade, the, 13; attitude of society toward, 425 .

Provincialism in colleges, 257-59.

Public-mindedness, 391.

Public speaking, 414.

Prudential Committee of American Board of Missions, 152-58.

Puritanism, revival of, in anti-slavery conflict, 7-12; after the Civil War, $12,13$.

Putnam, Professor, 35.

Quint, Rev. Dr. Alonzo H., 105, 209, 301.

Rainsford, William S., letter to Tucker, 429, 430.

Ranney, W. W., 183.

Raymond, Rossiter W., 370

Religion, of Boston and New York, compared, 72; and science, so-called conflict of, 94 ; the projection of, into the conditions of modern life, 97; academic, 262, 263.

Religious controversy in nineteenth century, 5, 6.

Religious coöperation, conditions not favorable to, after the Civil War, 63.

Religious effect of the social revolution of the nineteenth century, 16 .

Religious movement of eighteenth century, 273, 274.

Reparation, the question of, 434.

Republican party, the formation of, 11.

Rich, Charles A., 312.

Richardson, Professor Charles F., 347.

Richardson, Dr. Cyrus, 301.

Richardson, Judge James B., 301.

Ripley, George and Dick, 22.

Robertson, Frederick W., 58-62.

Robinson, ex-Governor, 207.

Robinson, Professor William C., 351.

Rockwood, Mrs. George I., 396.

Rogers, Charlotte, wife of Professor Tucker, 229.

Rogers, John, 229. 


\section{INDEX}

Rollins, Governor, 380.

Rollins Chapel, 313, 402.

Roosevelt, Theodore, 422 .

Ropes, Joseph T., 104.

Rowe, Sam, 26.

Russell, Charles Theodore, 105.

Russell, Thomas H., 104.

Russell, Judge, 197, 199.

Ryder, Professor, 124.

Sabbatical year at Dartmouth, 406.

Salem race-track, 387, 388.

Sanborn, Professor, 35.

San Francisco, 370.

Sayward, Judge, 396.

Schaff, Philip, 74.

Scholarship, the corporate spirit a stimulus to, 255-57; need of an avocation in, 393.

Schools, addresses of Tucker at, 372.

Science and religion, so-called conflict of, 94 .

Scientific renaissance of nineteenth century, 4-7.

"Second probation," 108, 109, 125, 126, 128, 131.

Sectarianism in colleges, 262, 263.

Sedgwick, Ellery, 443, 446.

Seelye, President Julius H., 105, 108, $117,203,209$.

Self-education, 1.

Sewall, Professor, 168.

Sewall, Oliver D., 183.

Shattuck, George O., 207.

Shedd, William G. T., 74, 138.

Sills, President, 363.

Slavery issue, the, 7-12.

Smith, President, 351.

Smith, Edwin R., 183.

Smith, Prof. Henry B., 74.

Smith, Jeremiah, 288.

Smith, Dr. William T., 395.

Smyth, Professor Egbert C., 124; article in the "Review" by, 140, 141; specifications on which he was condemned, 143; personal sketch of, 146; reply of, to letter of Dr. Eustis, 193; his argument, at trial, 199, 200; condemned by Board of Visitors, 203; appeals to Supreme Court of Massachusetts, 205; reinstated, 208; complaint against, renewed, 211; case against, dismissed, 212, 213; the result of the trial a personal triumph for, 214, 215 .

Smyth, Dr. Newman, 55; his reputation, 106; controversy over, 10t-16; at the First Church of New Haven, 116, 117; refuses new chair offered by Trustees of Andover, 118, 119.

Snow, Francis H., 54.

Social Christianity, 16, 97.

Social conscience, 424,425 .

Social Economics at Andover, 172-77.

Social justice, 17.

Social order, the new, 14-17.

Social progress, Tucker's views on, 422-27.

Social settlements, 17, 426 .

Socialism, the danger in, 16 ; communistic, 17.

Sociological studies, connection of Andover with, 172-77, 181-84.

South End House. See Andover House.

Spalding, C. W., 303.

Spalding, Dr., $66 n$.

Stanley, Dean, 81.

Starbuck, Professor C. C., 137.

State, conception of, as power, 42729.

Stearns, Edward R., 183.

Storrs, Richard S., 73.

Stowe, Professor Calvin E., 57.

Stowe, Harriet B., 57.

Strain, physical and mental, 394.

Streeter, Frank S., 301, 436.

"Struggle for existence," 9z, 93.

Sullivan, Attorney-General, 288.

Syndicate, the, 15 .

Tappan Wentworth Fund, the, 303.

Taylor, Edward, 104.

Taylor, Dr. John P., 124, 137.

Taylor, Dr. William M., 73.

Teague, Henry N., 313.

Tennyson, Alfred, 254.

Thackeray, W. M., 81.

Thayer, General Sylvanus, 358.

Thayer, Professor, 121-23.

Thayer School, the, 351, 358, 359.

Theological freedom, 217, 218.

Theology, progressive movement in, 90-99. See Progressive movement.

Tibbetts, Mr., 316.

Tilden, Samuel J., 79, 80.

Torrey, Daniel T., 154.

Toynbee Hall, 181.

Travel, value of, 392,393 .

Trust, the, 15.

Trustees, Board of. See Andover Theological Seminary, Andover Trial.

Tuck, Amos, 320.

Tuck, Edward, benefactions of, 31921, 355-58. 
Tucker, Robert, early ancestor of William J. Tucker, 20.

Tucker, William ("Squire Tueker"), grandfather of Villiam J. Tucker, 20; his house at Norwich, 21; charaeter of, 21,22 .

Tueker, William J., the character of his generation, 1 ; the fortune of his generation, 1-18; the purpose of his generation, 2 ; the heritage of his generation, 7; his approach to his generation, 19; his ancestry and early home at Norwich, 20-24; influence of grandfather and mother on, 24; taken into the household of Rev. IV. R. Jewett, 24; journey of, to Plymouth, N.H., 24, 25; boyhood life of, at Plymouth, 27-30; his early sehooling, 27; his early reading, 28, 29 ; his preparation and examinations for college, 35 ; moral effeet of the college freedom on, 36 ; and college routine, 36,37 ; precluded from taking great active part in Civil WVar, 42; effect of illness upon, $42 n$.; teaching in Columbus, Ohio, 45; his service in the United States Christian Commission, 48-50; on the march from Atlanta to the sea, 50; changes from the law to the ministry, 53, 54; at Andover Seminary, 55-58; his debt to Frederick IV. Robertson, 58-62; in service of American Home Missionary Society, 63; in the Franklin Street pastorate, Manchester, N.H., 61-71; influenee of the pastorate on, 66,67 ; on the need of clear, terse, and truthful speech in the ministry, 67; experiment of, in the constructive study of the Bible, 6769 ; in the Madison Square pastorate, 71-89; his first sermon in the new pastorate, 75,76 ; finds responsive congregation, 76, 77; his pastoral lectures, 77,78 ; personal associations with men of public value, 7883.

Goes to Andover Theological Seminary, 86-89; report of meeting accepting resignation from pastorate, $88 \mathrm{n}$.; letter of, to Mr. Hardy on Newman Smyth, 112-14; letter of President Hyde to, $112 n$; his reason for urging aeceptance of new ehair on Simyth, 119; Bartlet Professor of Sacred Rhetoric, 124; delivers sermon at Fitchburg, Mass., 126-28; his Sunday engagements, 129, 130; on the modern orthodox view of Christ, 132; his conception of the person of Christ, 134, 135; proposal as candidate for presidency of American Board of Missions, $158 \mathrm{n}$; his work in the Lectureship on Pastoral Theology, 161, 169-72; his chair of Preaching, 162; his lectures on "The Making and Unmaking of the Preacher," 162, 163; lectures of, on the technique of preaching, 163-65; coöperates in preparation of hymn book, 166-69; gives courses in Soeial Economies, 173-76; his statement covering his subscription of the Andover Creed, 200-02: elected to Presidency of Dartmouth, 222; considerations for and against his acceptance of the Presidency, 222-25, 237; letter of, to Trustees of Dartmouth, declining call to Presidency, 225-28; domestic affairs of, 229-31; Phi Beta Kappa Oration of, 232, 233; decides to accept Presidency of Dartmouth, 238; letter of Judge Bishop to, 238; editorial in "Andover Townsman" on, $239 n$.; letters of resignation from Andover and acceptance of Presideney to Dartmouth, 240-44; his view's as to location of theological schools, 246; his objeet, to give to Dartmouth its possible institutional development, 268, 269 ; lines on which he proposed to develop Dartmouth, 269-71; address of, at the grave of Wheeloek, 278-80; address at inauguration of Dr. Niehols, 280-82; from his address on the Origin of the Dartmouth College Case, 283-85; address at Webster Centennial, 290-92; confined himself to administrative duties at Dartmonth, 318; his reason for approving of athletics, 332-36; tries to gain access to the mind of the College, 339,340 ; ehapel talks of, $340-49$; tries to develop sense of the personal, 341-43; his "Personal Power," 343,419 ; tries to develop sense of the human, 343, 344; his "Public-Mindedness," 344,418 ; tries to develop religious sense, 344, 345; his Lowell lectures, 364-66; letter of Dr. Cabot on the preaching of, 366,367 ; serves as preacher at Harvard Iniversity, 367,368 ; lectures at Iale, 368 ; lec- 
tures of, on the Morse Foundation, 368, 369; takes part in Plymouth Church celebration, 370 ; not interested in the technical and conventional, 371; various addresses of, 371, 372; his interest in State of New Hampshire, 377, 378; speech on presentation of battle-flags to Gov. Johnston of Alabama, 381-84; on committee connected with New England Breeders' Club affair, 386; his name mentioned in connection with the governorship of New Hampshire, 388; his position in regard to politics, 389,390 ; on politics as a profession, 390, 391; on publicmindedness and citizenship, 391 ; on avocation and value of travel, 392, 393 ; on play and work, 394,395 ; at York Harbor, 396; breakdown in his health, 396,397 ; his letter of resignation, 397, 398; second letter of, agreeing to partial service, 399,400 ; at Nantucket, 400-02; fund bearing his name, 402; interest in academic productivity of Dartmouth, 403-05; interest in pension system, 405, 406; services of, in second year under temporary withdrawal of resignation, 406; introductory statement of report of, 406, 407; communication of, to "The Dartmouth" on President Nichols, 408, 409; speech of, at Alumni Dinner, 409-13.

Satisfactions growing out of his retirement, 414-16; buys house on Occom Ridge, 415; his daughters and sister, $415 n$.; on the New Reservation of Time, 417, 418; edits addresses, 418, 419; monogreph on "The Function of the Church in Modern Society," 419; at reunion of the "Boys of "61," 419; his attitude toward Mr. Roosevelt and the Progressives, 422 ; his views and articles on social progress, $422-27$; his views on the ethical element in the War, 427-29; his article, "The Ethical Challenge of the War," quoted, 428, 420; letters of Rainsford and Hough to, 429, 430; his article, "The Crux of the Peace Problem," 430, 431; his article "On the Control of Modern Civilization," 431, 43z; on the Pope's proposal for intervention, 432, 433; on the mind of Germany, 434; on the study of the German language, 434-38; his views on our participation in world affairs, 438-42; his book, "The New Reservation of 'Time," 443; on peace as the aim of the incoming generation, 449-51.

Union Theological Seminary, stronghold of advanced Presbyterianism of New York, 73, 74, 87; its attempt to liberalize the doctrine of Scripture, 99; freed from visitatorial control, 119,120 ; lectures by Tucker on the Morse Foundation at, 368, 369.

Unions, labor, 15.

Unitarian Club, addresses at, 131-34.

Unitarianism, its relation to the Andover movement, 131-35.

United States Christian Commission, the, 48 .

United States Hotel, 24, 25, 198.

United States Sanitary Commission, the, 48.

Universities. See Colleges.

Lpton, Judge Samuel, letter of, 68.

Vallandigham, C. L., arrest and banishment of, unwise, 45.

Vermont and New Hampshire, struggle between, 373,374 .

Visitorial system, the, 119, 216.

Visitors, Board of. See Andover Theological Seminary, Andover Trial.

Vose, Rev. Dr. James G., 105.

Waldron, Dr., 54.

Walker, Rev. Dr. George Leon, 105, 209.

Wallace, Rev. Cyrus W., 65.

War, the spirit of, 449,450 .

War, the, the moral issue in, 427-34.

Ward, Benjamin, 26.

Ward, Julius H., 365.

Ward, Dr. William Hayes, 111.

Wealth, the Gospel of, 178-80; and institutionalism in colleges, 263.

Webster, Daniel, 8, 25; counsel in Dartmouth College Case, 288, 289; centennial of graduation of, 289 ; address of President Tucker at Centennial, 290-92.

Webster Centennial, the, 289.

Webster Hall, 322.

Wellman, Arthur H., 197, 199.

Wellman, Rev. Dr. J. W., 104, 211.

Wells, Professor David Collins, 230, 317.

Wells, Mrs. D. C., sister of President Tucker, 230, $415 n$. 
Wentworth, Tappan, 303.

Wheeler, Mrs. Leonard, 396.

Wheelock, Dr. Eleazar, 268; his Indian School, 23, 272-76; his religious life, 274; and Whitefield, 274, 275 .

Wheelock, John, son of Dr. Wheelock, appointed President of Dartmouth, 283, 284; conflict of, with Trustees, 285, 286; deposed, 287, 292, 293.

"Wheelock Succession, The," 280-83.

White, Sarah, Tucker's mother, 22 .

Whitefield, George, 274, 275.

Wickham, Mayor, 77 .

Wilcox, Rev. Dr. William H., 104.

Wilder, Charles T., fund given by, 304 .

Will, the, Professor Park's division of, 56.
Wilson, Woodrow, from address of, on academic communities, 252 .

Woodruff, Professor Frank E., 124.

Woods, Robert A., 181, 231, 367, 448.

Woodward, Judge, 287, 375.

Work, change in attitude toward, after the Civil War, 15; and play, 394, 395.

Worship, public, 166-69, 171.

Wright, Prof. George Frederick, 5, 136.

Yale University, endowment of, 264;

Tucker lectures at, 368 .

York Harbor, 396.

Young, Professor Ira, 35.

Zerviah, Aunt, 21. 



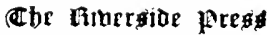

CAMBRIDGE - massachusetts

U . S . A 



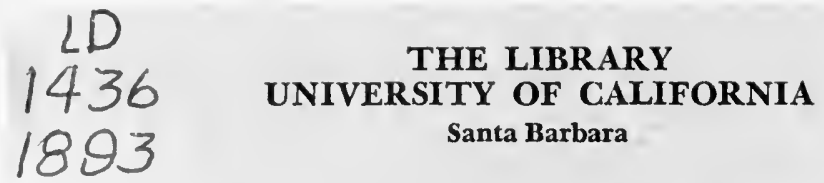

THIS BOOK IS DUE ON THE LAST DATE STAMPED BELOW. 
